\title{
UNIVERSITY SQUARE DEVELOPMENT PROPOSAL
}

A Project presented to

the Faculty of California Polytechnic State University, San Luis Obispo

In Partial Fulfillment

of the Requirements for the Degree

Master of City and Regional Planning

by

Tom Gregory Van Pelt

June 2014 
(C) 2014

Tom Gregory Van Pelt ALL RIGHTS RESERVED 
COMMITTEE MEMBERSHIP

TITLE:

AUTHOR:

DATE SUBMITTED:

COMMITTEE CHAIR:

COMMITTEE MEMBER:

COMMITTEE MEMBER:
University Square Development Proposal

Tom Gregory Van Pelt

June 2014

Vicente del Rio, PhD

Professor of City and Regional Planning

Michael Multari

Lecturer in City and Regional Planning

Joshua Cross

Senior Planner, RRM Design Group 


\section{ABSTRACT \\ University Square Development Proposal}

Tom Gregory Van Pelt

The University Square Development Proposal (USDP) explores the redevelopment of the underutilized University Square site (the Site) in the City of San Luis Obispo (the City.) The Sites proximity to California Polytechnic State University, San Luis Obispo (Cal Poly), a university with significant student housing needs, makes it an ideal location for student housing. The City has also expressed interest in the Site, having identified it in the General Plan Land Use and Circulation Element (LUCE) update as a "Special Planning Area". The LUCE proposes a new mixed-use typology on the Site that may include a mixture of multi-family housing, retail services, entertainment, and recreation.

The USDP is an early take on redevelopment of the Site, and provides a development option that accommodates both the objectives of Cal Poly, by providing student housing, and the City, by proposing a mixed-use development typology. To this end, the USDP includes a site assessment, project program, design vision, and financial analysis. The USDP concludes with project evaluations and lessons learned. 
THIS PAGE INTENTIONALLY LEFT BLANK 


\section{ACKNOWLEDGMENTS}

\section{PROFESSIONAL PROJECT COMMITTEE:}

Vicente del Rio, Ph.D. (Chair), Professor of CRP, Cal Poly

Michael Multari, Lecturer in CRP, Cal Poly

Joshua Cross, Senior Planner, RRM Design Group

\section{SPECIAL THANK YOU TO:}

Nicholas Thomkins, NKT Commercial

Ron Van Pelt, WATG

Umut Toker, Ph.D., Associate Professor of CRP, Cal Poly

R.Thomas Jones, Professor of Architecture, Cal Poly

The Architecture and Planning Landscape Architecture Groups at RRM Design Group

\section{PROJECT PREPARED BY:}

Tom Van Pelt, Master of City and Regional Planning, Cal Poly

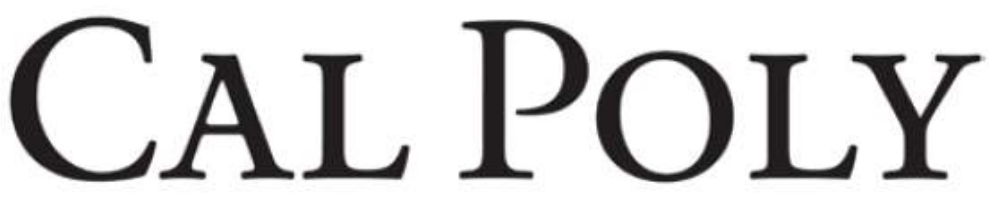

SAN LUIS OBISPO

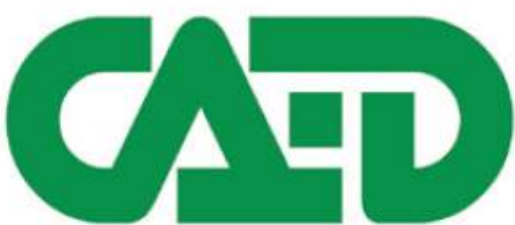

COLLEGE OF ARCHITECTURE \& ENVIRONMENTAL DESIGN

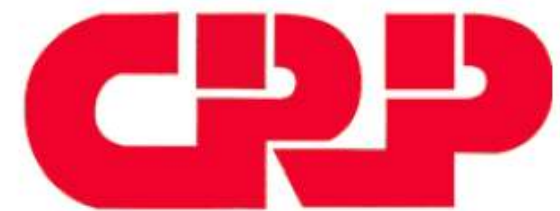

CITY \& REGIONAL PLANNING 
THIS PAGE INTENTIONALLY LEFT BLANK 


\section{TABLE OF CONTENTS}

LISTOF TABLES .1

LIST OF FIGURES 3

1.0 INTRODUCTION

1.1 Project Overview................................................ 7

1.1.1 Introduction............................................ 7

1.1.2 Cal Poly Housing Needs......................... 7

1.2 Project Objectives............................................ 8

1.3 Document Structure.......................................... 9

2.0 FOUNDATIONS FOR THE PROJECT.......................11

2.1 Project Methodology......................................... 13

2.2 Urban Design Principles..................................... 13

2.2.1 Human Scale......................................... 15

2.2.2 Respect for the Pedestrian.......................15

2.2.3 Variety in Land Uses...............................16

2.2.4 Variety in Human Activity..........................17

2.2.5 Well Maintained Buildings and Public

Spaces 18

2.2.6 Inclusion of Green Space..........................18

2.2.7 Building Setbacks Close to the Street.........19

2.2.8 Unified Building and Natural Materials.........19

2.2.9 Functionality.........................................20

2.2.10 Connections and Permeability.................20

2.3 Mixed-Use Development Principles.......................22

2.3.1 Clearly Defined Objectives........................22

2.3.2 Determining the Cornerstone Use.............22

2.3.3 Treating the Public Sector as a Partner.......23

2.3.4 Understanding the Market.........................23

2.3.5 Create Value for Investors......................23

2.3.6 Sustainability........................................24

2.3.7 Availability of Funds............................24

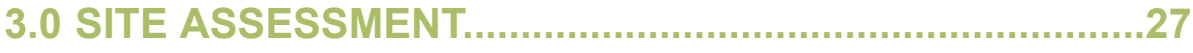

3.1 Site Location.....................................................27

3.2 Neighborhood Character and Context....................31

3.3 Existing Structures...........................................33

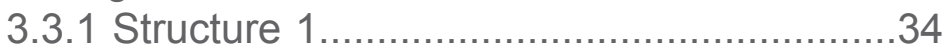

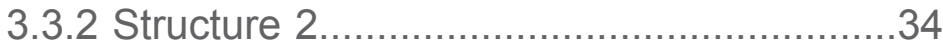

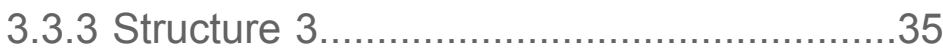

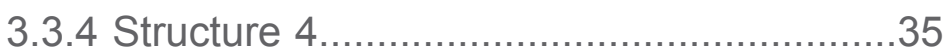

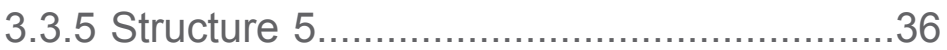

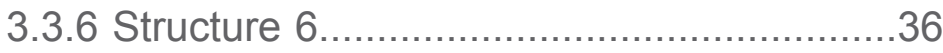

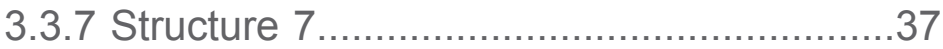

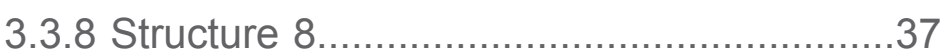

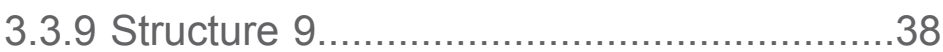

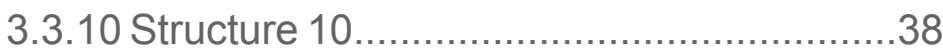

3.4 Land Ownership...............................................39

3.5 Zoning and Land Use Regulations......................40

3.5.1 Zoning................................................. 40

3.5.2 Adjacent Land Uses and Zoning..............41

3.5.3 Land Use Regulations.............................41

3.5.4 Land Use and Circulation Update...........41

3.6 Circulation..................................................... 42

3.6.1 Streets..................................................4 42

3.6.2 Transit.................................................... 43

3.6.3 Parking and Site Ingress/Egress..............44

3.6.4 Pedestrian and Bike Routes......................44

3.7 Utilities....................................................... 45

3.8 Topography and Soils......................................46

3.9 Hydrology and Drainage .................................47

3.10 Views.......................................................... 48

3.11 Climate and Solar Orientation...........................49

3.12 Market Assessment...........................................51

3.12.1StudentHousing Market..........................51

3.12.2 Retail Market........................................53

3.12.3 Mixed-Use Market..................................53

3.13 Conclusion.................................................... 55 
THIS PAGE INTENTIONALLY LEFT BLANK 


\section{TABLE OF CONTENTS}

4.0 PROGRAM DEVELOPMENT_................................ 57

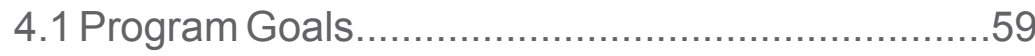

4.2 Student Housing ........................................... 59

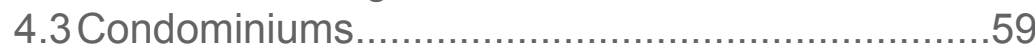

4.4Retail.......................................................... 61

4.5Parking......................................................... 51

4.6 Public Spaces and Rights-of-Way......................62

4.7The Program...................................................63

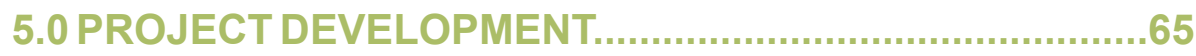

5.1 Design and Vision........................................67

5.1.1 Design Options....................................67

5.1.2 The University Square Development

Proposal Vision......................................67

5.1.3 Vehicle Circulation and Parking.................75

5.1.4 Transit Circulation....................................76

5.1.5 Pedestrian Circulation............................ 77

5.1.6 Bike Circulation...................................... 78

5.1.7 Evaluating the Vision...............................79

5.2 Sustainability Design Guidelines.......................81

6.0FINANCING

6.1 Assumptions.................................................... 89

6.2 Construction CostEstimates.............................89

6.3 Cash FlowAnalysis..........................................91

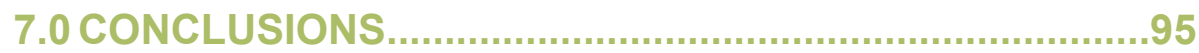

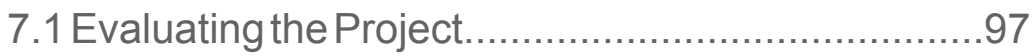

7.2 Lessons Learned.............................................98

7.2.1 It Takes a Team!.....................................98

7.2.2 Aggressive Time Line...............................98

7.2.3 The Fire Station.................................... 98
APPENDIX A: CASE STUDY ANALYSIS...........................

A. 1 Introduction......................................................105

A.2 South Campus Gateway - The Ohio State

University. 105

A.2.1 Project Description

A.2.2 Urban Design Matrix Evaluation

A.2.3 Mixed-Use Development Matrix

Evaluation.

A.2.4 Conclusions.

A.3 Technology Square - Georgia Institute of

Technology......

A.3.1 Project Description.................................107

A.3.2 Urban Design Matrix Evaluation...............108

A.3.3 Mixed-Use Development Matrix

$$
\text { Evaluation.... }
$$

A.3.4 Conclusions.

A.4 University Park at MIT - Massachusetts Institute of Technology... 109

A.3.1 Project Description

A.3.2 Urban Design Matrix Evaluation.

A.3.3 Mixed-Use Development Matrix

$$
\text { Evaluation...... }
$$

A.3.4 Conclusions. .111 
THIS PAGE INTENTIONALLY LEFT BLANK 
3.1 San Luis Obispo Age Distribution...........................27

3.2 Land Ownership Acreages.......................................39

3.3 Land Use Regulations..........................................4

3.4 San Luis Obispo Climate......................................49

3.5 San Luis Obispo Multi-Family Trends.....................52

3.6 San Luis Obispo Retail Sales Prices.......................53

4.1 Student Apartment Floor Plans and Areas.............60

4.2 Condominium Floor Plans and Areas.....................60

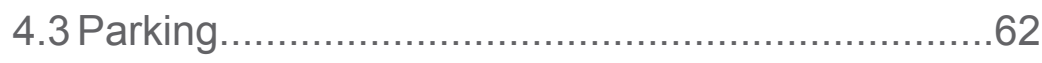

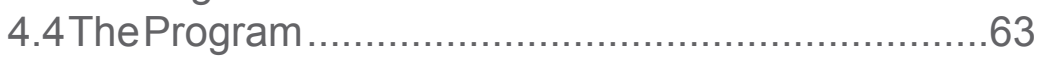

6.1 Construction Cost Estimate.....................................90

6.2a University Square Pro-Forma Years 1-8...............91

6.2b University Square Pro-Forma Years 9-20..............92 
THIS PAGE INTENTIONALLY LEFT BLANK 


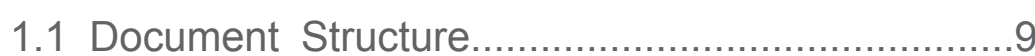

2.1 The University Square Development Process........14

2.2 The Urban Design Matrix........................................15

2.3 The Mixed-Use DevelopmentMatrix......

3.1 University Square in relation to the City, County, and State.

3.2 Distance and Average Walking Times between University Square, Downtown SLO, and Cal Poly.....

3.3 Site Dimensions....................................................

3.4 Figure-Ground Map...............................................31

3.5 Local Resources...................................................32

3.6 Structure Locator Map...........................................33

3.7 Parcels by Ownership Map......................................39

3.8 Current Zoning Map...............................................40

3.9 Street Classification Map....................................42

3.10 Bus Routes Map................................................43

3.11 Bike Routes and Parking Map..........................44

3.12 Utilities Map.......................................................45

3.13 Contours and Soils Map....................................46

3.14 Creeks and Flood Zones Map.............................47

3.15 Views In and Out Map........................................48

3.16 Solar Orientation on Buildings 4,5,6, and $7 \ldots \ldots \ldots . .50$

3.17 Mustang Village Typical Floor Plans...................51

3.18 Perception Matrix...............................................55

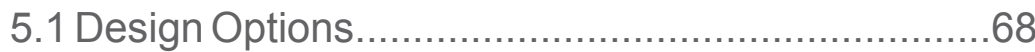

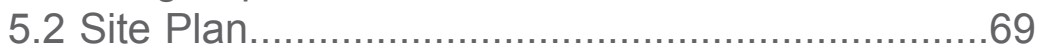

5.3 Land Use and Key Map.......................................70

5.4 Sections Locations Map..........................................71

5.5 Section A: Podium Terrace, Podium Parking, and Market. 5.6a Section B: Foothill Boulevard........................71

5.6b Section B: Foothill Boulevard............................72

5.7 University Square Perspective............................72

5.8 Public Spaces Map............................................... 73

5.9 Podium Terraces Locations Map.........................74

5.10 Vehicular Circulation and Parking Map...............75

5.11 Transit Circulation Map.....................................76

5.12 Pedestrian Circulation Map................................ 77

5.13 Bike Circulation Map.......................................78

5.14 University Square Urban Design Matrix................79

5.15 University Square Perception Matrix..................79

5.16 Proposed Re-Zoning Map...............................80

7.1 University Square Urban Design Matrix...............97 7.2 University Square Mixed-Use Development Matrix..97 
THIS PAGE INTENTIONALLY LEFT BLANK 
THIS PAGE INTENTIONALLY LEFT BLANK 


\subsection{PROJECT OVERVIEW}

\section{1 .1 Introduction}

The University Square Development Proposal (USDP) explores the redevelopment of the underutilized University Square site (the Site) in the City of San Luis Obispo. The Sites proximity to California Polytechnic State University San Luis Obispo (Cal Poly), a university with significant student housing needs, makes it an ideal location for student housing. However, the City has also expressed interest in seeing mix-use development on the Site to include a mixture of multi-family housing, retail services, entertainment, and recreation. The USDP is an early take on redevelopment of the Site, and provides a design solution and financial study that accommodates both student housing and the mixed-use development proposed by the City.

\subsubsection{Cal Poly Housing Needs}

As the California State University system's flagship campus, Cal Poly's "learn by doing" philosophy attracts students from across the nation, with a total 201314 enrollment of 19,800 students, representing the largest ever student enrollment in the University's history. Cal Poly President Jeffrey Armstrong expects that number to continue increasing to approximately 24,000 to 25,000 students by the year 2022 (The Tribune, 2013).

Though enrollment growth remains essential to Cal Poly's advancement, it also presents significant challenges to the University and the local community. Of these challenges, one of the most immediate and pressing is the need for quality student housing. The current market for student housing is split between the University's limited on-campus rentals and the surrounding communities rental markets. Cal Poly currently houses around 6,300 beds in nine residence halls and two apartment-style complexes, which accommodates approximately 32 percent of the University's total student enrollment (Lazier, 2013). The City of San Luis Obispo absorbs the majority of the overflow into its rental market of approximately 11,500 renter-occupied units (U.S. Census, ACS 2011, 5 year). However, this is not nearly enough housing to satisfy the City's student and non-student rental housing markets. Cal Poly has responded to the demand by increasing on campus housing units with Poly Canyon Village, a mixed-use development with living space for 2,600 students that opened in 2009, and a 1,400 student residence complex at the entrance of Grand Avenue slated for completion in 2018 (Lazier, 2013).

Both developments are a step in the right direction; however they do not fully account for demand, and do not serve Cal Poly's student body equally. University Housing, the entity that administers Cal Poly's housing program, is formally committed to providing housing to new students. However, it remains unable to provide housing for most undergraduate students, and provides limited to no housing for graduate students. Poly Canyon Village primarily houses students in their freshmen, sophomore, and junior years, and the

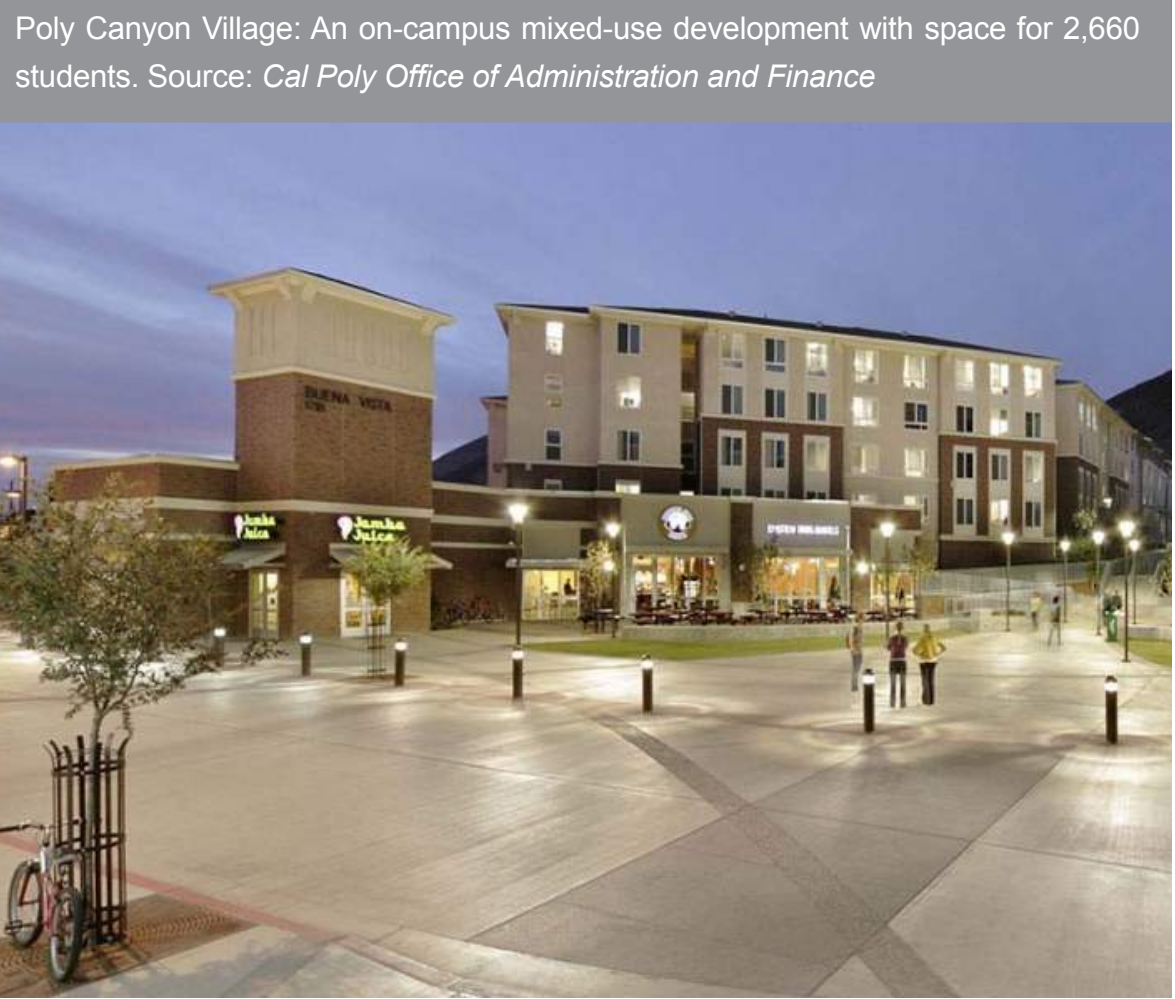


2018 Grand Avenue complex is slated to only house incoming freshman. Other North American universities have also struggled with increasing studenthousing demand. Those universities with additional land and capital resources are more easily able to adapt to this changing reality; however, universities lacking the means have had to seek alternative models to satisfy the demand. Many universities overcome obstacles and achieve housing goals through partnerships with the private development industry. These partnership models are varied, and can include the University as an equity or capital investor in an on or off campus project, or as a provider of land at limited or no cost.

Lack of student housing clearly presents a challenge for Cal Poly; but it also presents a major opportunity for both the University and the local development market. The University Square Development Proposal (USDP) explores the viability of the university as off-campus equity investor model in potentially helping Cal Poly with its current and projected housing demand. The USDP approaches this partnership model from the perspective of the private developer and will provide a construction cost estimate financial feasibility study and phasing plan for the off-campus 8.2 acre University Square Site.

\subsection{PROJECT OBJECTIVES}

The Site's current state leaves it ripe for redevelopment and creates an opportunity for a landmark project that provides additional housing, services, and amenities for Cal Poly, the City, and the region. The University Square Development Proposal (USDP) explores the development possibilities for the site and provides a strategy for achieving the following:

1) Feasibility: Achieve a financially feasible design and development solution for the University Square Site.
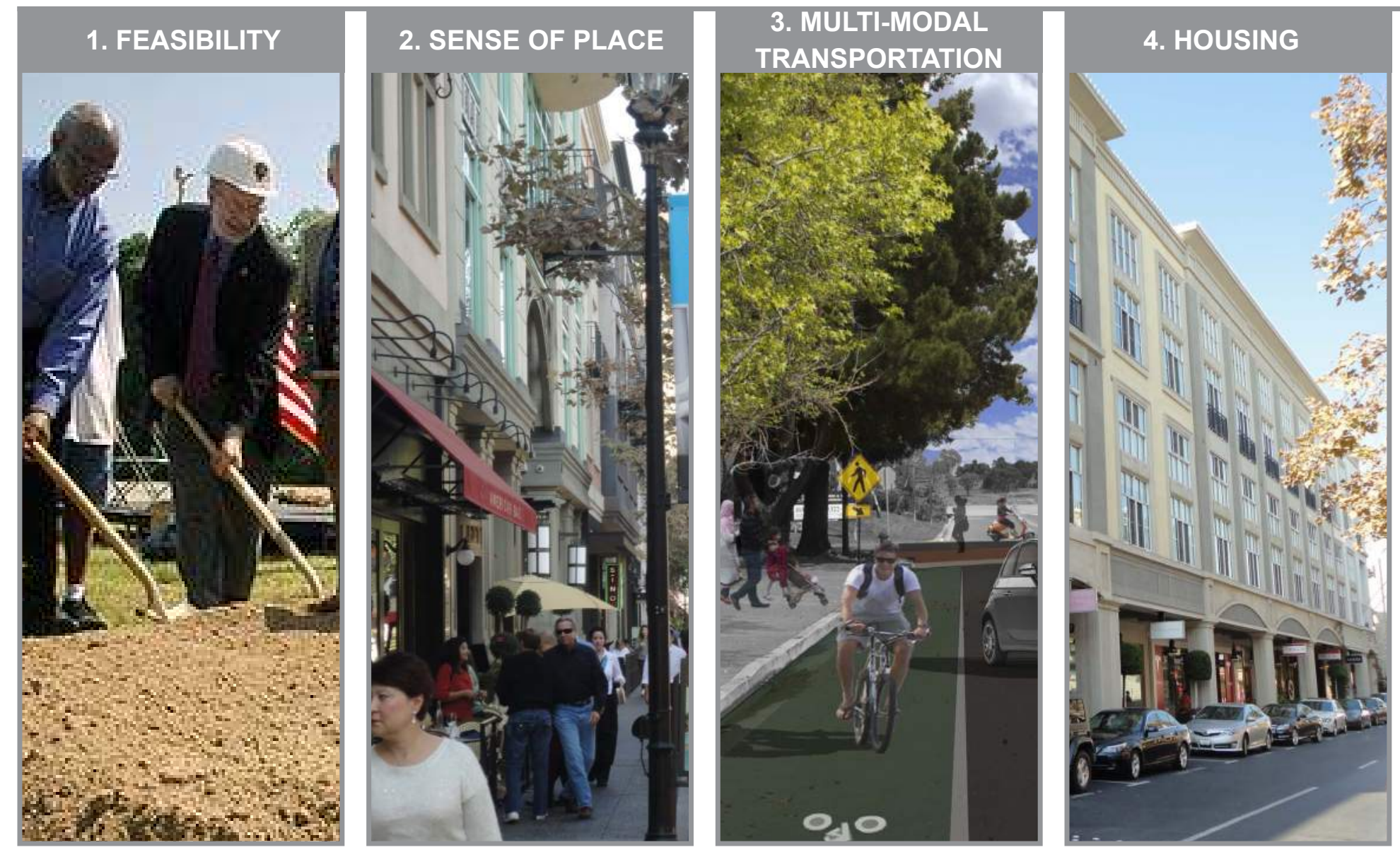

\section{SUSTAINABILITY}

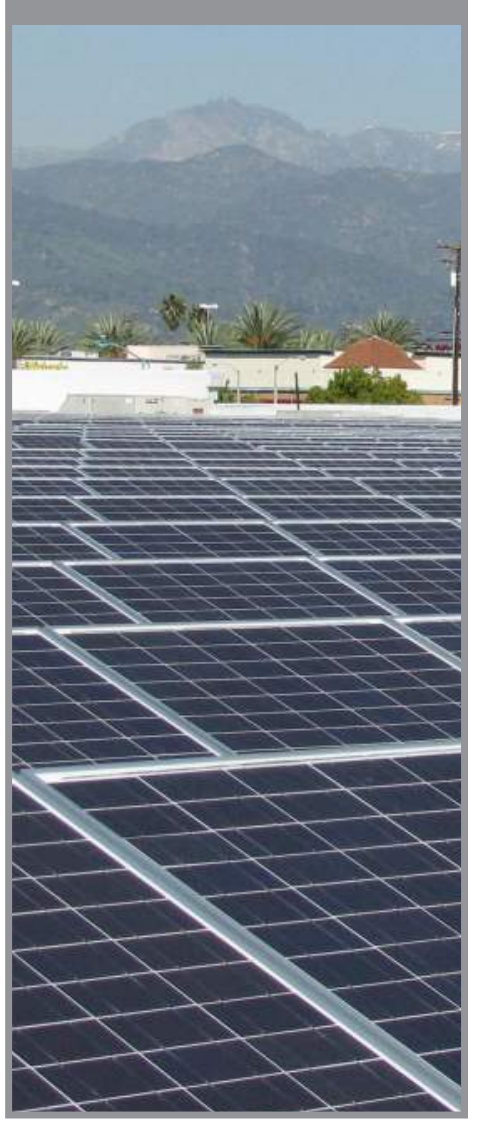


2) Sense of Place: Provide a design that rehabilitates the Site's image and creates a unique sense of place.

3) Multi-Modal Transportation: Create opportunities for residents and visitors to use alternative modes of transportation such as walking, bicycling, and transit.

4) Housing: Develop housing for both Cal Poly students and the local San Luis Obispo community.

5) Sustainability: Design with the natural environment in mind and provide sustainable solutions that negates the project's environmental impact and enhances the Site's environmental quality.

\subsection{DOCUMENT STRUCTURE}

This document is organized into six distinct sections: 1. Introduction, 2. Foundations for the Project, 3. Site Assessment, 4. Program Development, 5. Project Development, and 6. Financing and Implementation. The document also has an appendix with case study evaluations that were conducted in preparation for the project.

1.0 Introduction: This Section provides an overview of the University Square Project, and includes a discussion of the project purpose, context, and objectives.

2.0 Foundations for the Project: This Section discusses the methodology undermining decisions made with the University Square Development Proposal. It includes a discussion of urban design and mixed-use development principles, and the tools used to evaluate outcomes for University Square.

3.0 Site Assessment: This Section introduces the Site and provides a context-specific inventory and analysis of the University Square Site's physical and biological attributes, and an assessment of the local real estate market.

1.0 INTRODUCTION

PAGE 1

2.0 FOUNDATIONS FOR THE PROJECT

PAGE 7

3.0 SITE ASSESSMENT PAGE 21

4.0 PROGRAM DEVELOPMENT PAGE 53

5.0 PROJECT DEVELOPMENT PAGE 61

6.0 FINANCING PAGE 83 
4.0 Program Development: This Section provides a program that defines the product and quantity of development on the Site.

5.0 Project Development: This Section builds on the previous sections and provides the design, vision, and sustainability design guidelines for the Site.

6.0 Financing and Implementation: This Section provides the financial feasibility study for the University Square Project, which includes construction cost estimate and a cash flow analysis (pro-forma). 
FOUNDATIONS FOR THE PROJECT

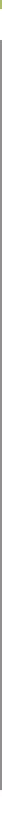


THIS PAGE INTENTIONALLY LEFT BLANK 
The complex nature of large-scale land development is such that a carefully prescribed methodological approach is helpful in achieving successful outcomes. The University Square Development Proposal (USDP) includes four research methods:

1. Site Assessment

2. Market Analysis

3. Literature Review

4. Case Study Analysis

Figure 2.1 diagrams the University Square Development process, and shows how these four methodologies fit into the overall land planning, design, and development process. The Site Assessment (Section 3.0) provides a context-specific inventory and analysis of the University Square Site's physical, biological, and cultural attributes. The Market Analysis was undertaken as a part of the Site Assessment in Section 3, and affords a better understanding of the preferences and desires of the target market. The Literature Review is discussed further in this Section, and provides a conceptual framework for discussion of good urban design and mixed-use development principles. The Case Study Analysis, which is attached as Appendix A, used the outcomes of the Literature Review to evaluate the effectiveness of university/private partnership developments analogous to the partnership model and development typology being proposed in the USDP.

The fields of urban design and mixed-use development are both vast and multifaceted in their own right. Each body of knowledge has deep academic and professional roots. The Literature Review is by necessity limited in scope, and serves not as a definitive review of each subject but rather as an ideological guide specific to the USDP. The Literature Review is divided into two sections by subject: 2.2 Urban Design Principles, and 2.3 Mixed-use Development Principles. The process revealed two separate analysis matrixes for each subject, supplying a methodological framework in analyzing both the case studies and the urban design and mixed-use development decisions made within the USDP.

\subsection{URBAN DESIGN PRINCIPLES}

This Section provides a discussion of the good urban design principles that emerged during the Literature Review. Urban design is an especially difficult phrase to define because the body of knowledge associated to urban design is so vast. For simplicity and the purposes of this project, urban design refers to the basic shaping and grouping of buildings, streets, and the public and private spaces between buildings. Urban design products within the USDP include the site master plan and the sustainability design guidelines. This Literature Review explores five bodies of work related to urban design processes and principles: City Building by John Lund Kriken, The Nature of Urban Design by Alexandros Washburn, The New Urbanism by Peter Katz, Public Places Urban Spaces by Matthew Carmona, Steve Tiesdell, Tim Heath, and Tanner Oc, Retrofitting Suburbia by Ellen Dunham Jones and June Williamson. The review and analysis of these works consolidates urban design processes, objectives, and principles into the "Urban Design Matrix;" a diagnostic chart with the following ten categories that can be used to evaluate good urban design projects and practice:

Human Scale

Respect for the Pedestrian 


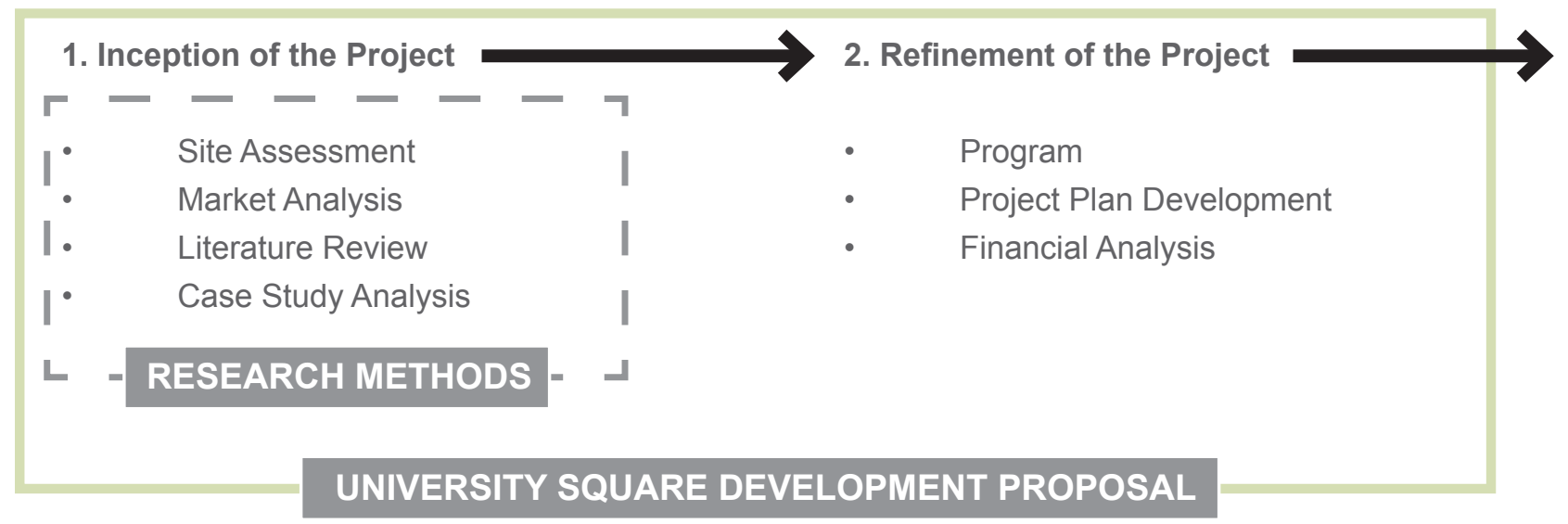

\section{Feasibility}

- $\quad$ Formal Market Study

- Refine Program

- Refine Project Plan

- Extensive Financial Analysis

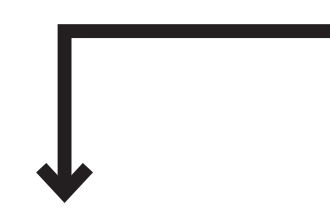

4. Contracts and Entitlements

5. Construction

- Construction Schedule

- Marketing
6. Completion

- $\quad$ City Approves Occupancy

- Marketing

- Loan Commitments

- Final Design

- Construction Documents

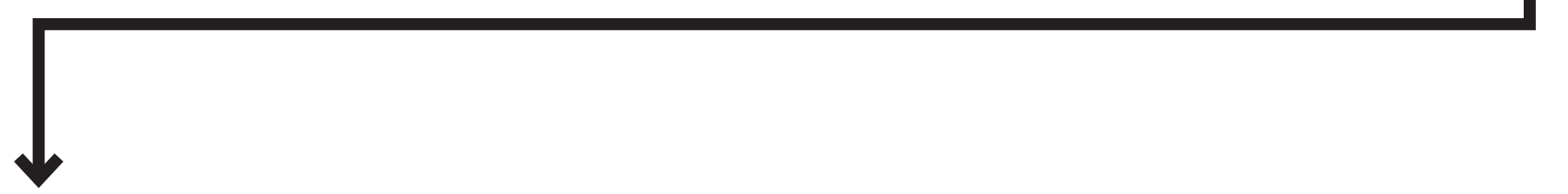

7. Sales and Property Management

- $\quad$ Sales and Leasing

- $\quad$ Oversee Property Management 
- Variety in Land Uses

- Variety in Human Activities

- Well Maintained Buildings and Public Spaces

- Inclusion of Green Space

- $\quad$ Building Setbacks close to the Street

- Unified Building and Natural Materials

- $\quad$ Functionality

- Connections and Permeability

Figure 2.2: The Urban Design Matrix, contains the urban design principles in rows and the score measurement in columns. The maximum score a project can receive is 20 points, while the minimum is 0 points. If the project scores 15-20 points it can be considered to exhibit good urban design qualities. If it has 9-14 points it can be considered to exhibit fair urban design qualities, and less than 8 can be considered as having poor urban design qualities.

\subsubsection{Human Scale}

Scale is the proportion of one object to another. In urban design, the scale of

FIGURE 2.2 - The Urban Design Matrix

\begin{tabular}{|l|l|l|l|}
\hline Urban Design Principle & \multicolumn{1}{|c|}{ Good (2) } & Fair (1) & Poor (0) \\
\hline Human Scale & & & \\
\hline Respect for Pedestrian & & & \\
\hline Variety in Land Uses & & & \\
\hline $\begin{array}{l}\text { Variety in Human } \\
\text { Activities }\end{array}$ & & & \\
\hline $\begin{array}{l}\text { Well Maintained } \\
\text { Buildings and Public } \\
\text { Spaces }\end{array}$ & & & \\
\hline $\begin{array}{l}\text { Inclusion of Green } \\
\text { Space }\end{array}$ & & & \\
\hline $\begin{array}{l}\text { Building Set-backs } \\
\text { Close to the Street }\end{array}$ & & & \\
\hline $\begin{array}{l}\text { Unified Building and } \\
\text { Natural Materials }\end{array}$ & & & \\
\hline Functionality & & & \\
\hline $\begin{array}{l}\text { Connections and } \\
\text { Permeability }\end{array}$ & & & \\
\hline
\end{tabular}

buildings, landscaping elements, and the street are important in creating a feeling of comfort and understanding. Human scale is the term used to describe a comfortable scale that usually includes building masses, landscapes, and streets that are modest in size and in scale with their surroundings.

In his work City Building, John Lund Kriken discusses human scale as a fundamental aspect of urban design. He discusses the "townscape" concept established by the British Planner Gordon Cullen, in which the "urban domain is experienced sequentially on foot" (Kriken,2010). Human scaled townscapes are pedestrian oriented and can be established with the size and orientation of buildings open spaces, materials, landscape, lighting, and street furniture. Each of these elements helps to define a space, and can be used to make people "feel comfortable and awe inspired" (Kriken, 2010).

\subsubsection{Respect for the Pedestrian}

While human scaled buildings, streets, and public spaces are oriented towards the pedestrian, circulation patterns that respect the pedestrian and promote walkability greatly enhance the liveliness and accessibility of a place. In his

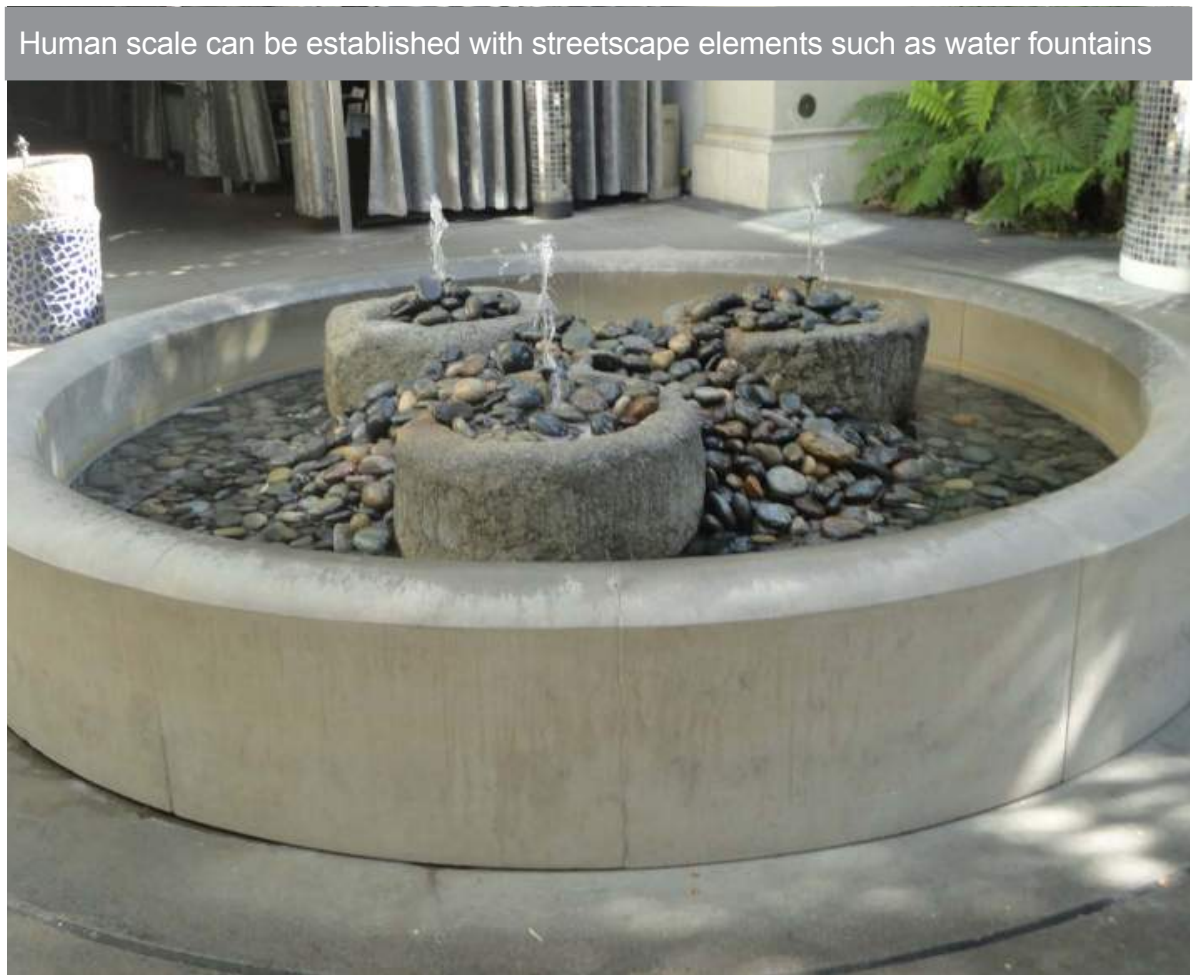


Floorscape patterns are elements of the street that contribute to the overall pedestrian environment work The Nature of Urban Design, Alexandros Washburn argues that urban design should promote the primacy of the pedestrian point of view: "I believe in the primacy of the pedestrian point of view. I believe that values that respect the environment, the economy, and society are best represented by a point of view that is sustainable, humanist, and experiential - the pedestrian point of view is all of these. The pedestrian point of view is humanist because it puts every decision at a human eye level. Because the street is public and experienced by all citizens, the perspective presupposes a concern for social equity; everyone has a right to the benefit of public space. Because the pedestrian comes first, the perspective is sustainable. The perspective highlights the great carbon savings of walkability, giving us our first best hope in helping our cities combat climate change" (Washburn, 2013).

Promoting the primacy of the pedestrian point of view means respecting the pedestrian throughout the design process to provide streets and places that are safe and convenient to access on foot. This is accomplished through the implementation of complete streets programs that promote wide sidewalks, landscaped streetscapes, pedestrian crosswalks, and minimum vehicular lane widths. Respecting the pedestrian also has a positive impact on public health. While a poorly designed road network can lead to congestion, air pollution that leads to respiratory problems and diseases such as asthma, emphysema, and bronchitis; a road network that respects the pedestrian provides a healthy streetscape that gives people the choice to walk, recreate, play.

Additionally, the visual aesthetic character of streets is often as much of an influence on pedestrian orientation as are the spatial properties. Elements of the street that contribute to a pedestrian environment include the "color, texture and detailing of surfaces" (Carmona, Tiesdell, Heath \& Oc, 2010), and can be applied to the key aspects of a streetscape. These details can include floorscape patterns, street furniture, signage, and public art.

\subsubsection{Variety in Land Uses}

Enjoyable places are usually those that meet a diversity of human demands. Development that functionally integrates a variety of land uses and meets these human demands is called mix-use development. Mixed-use development is any development that physically and functionally integrates a combination of residential, office, and commercial uses. $\neg$ Mixed-use development helps to the reduce the distances between housing, workplaces, and commercial 
uses which leads to more walkable environments with stronger neighborhood character, and a stronger sense of place.

While the USDP should incorporate a variety of land uses, it should also incorporate the notion of the "third space." The third space is described in Retrofitting Suburbia as a "neighborhood gathering places where local people routinely hang out and socialize. Common examples include the corner pub, diner, coffee shop, barbershop or hair salon, and even at times the hardware or general store" (Dunham-Jones \& Williamson, 2009). The third space is important in the success of a place because it reinforces social bonds and networks, and provides a social outlet for community members. Commercial strips, often lack a third space, can diminish from community building rather than enhance it. The third place concept should be incorporated in the development of the USDP and will be key to the success of redevelopment at University Square.

\subsubsection{Variety in Human Activity}

While a variety in land uses can accommodate prescribed human activities,

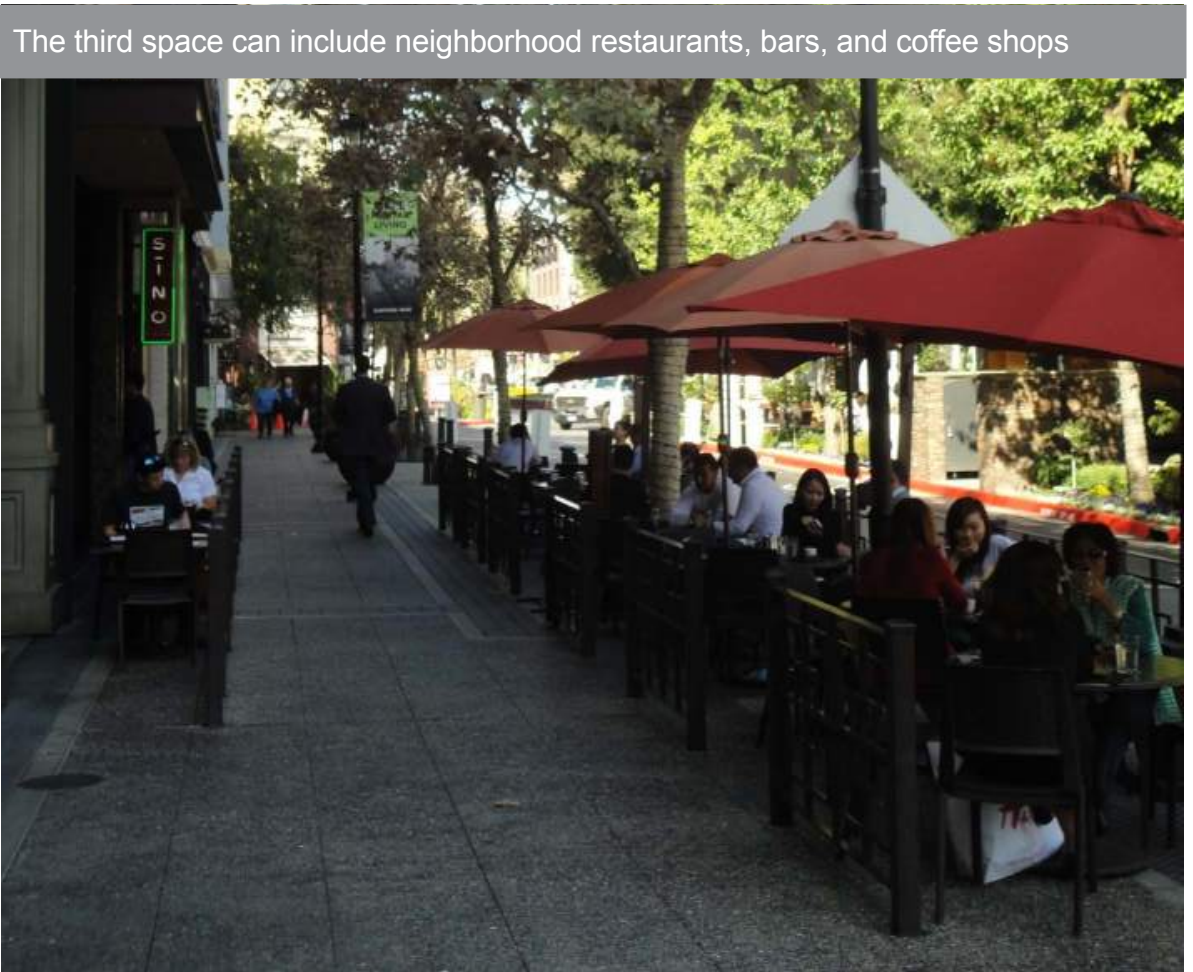

they do not by themselves encourage the informal and spontaneous activities that help make places special and vibrant. Good urban design can and should encourage a variety in human activities. The authors of Public Places Urban Spaces discuss Jan Gehl's theory of activities and urban design quality: " $(\mathrm{He})$ adopts a probabilistic approach to the relationship between design and activity. He argues that, through design and within certain limits - regional, climactic, and societal - it is possible to influence how many people use public spaces, how long individual activities last and which types can develop" (Carmona, Tiesdell, Heath \& Oc, 2010).

Gehl further argued that human activities can be broken down into three categories: necessary activities (work, school, shopping, etc.), optional activities (sitting at a coffee shop, listening to an outdoor performance, etc.), and social activities (greetings, conversations, etc.) He argues that necessary activities "are more or less compulsory....and, as the participants have no choice, their incidence is only slightly influenced by the physical setting," Carmona, Tiesdell, Heath \& Oc, 2010). Although he is correct in the assertion that necessary activities are required of their participants, he fails to mention that the physical setting can greatly enhance the participant's enjoyment of

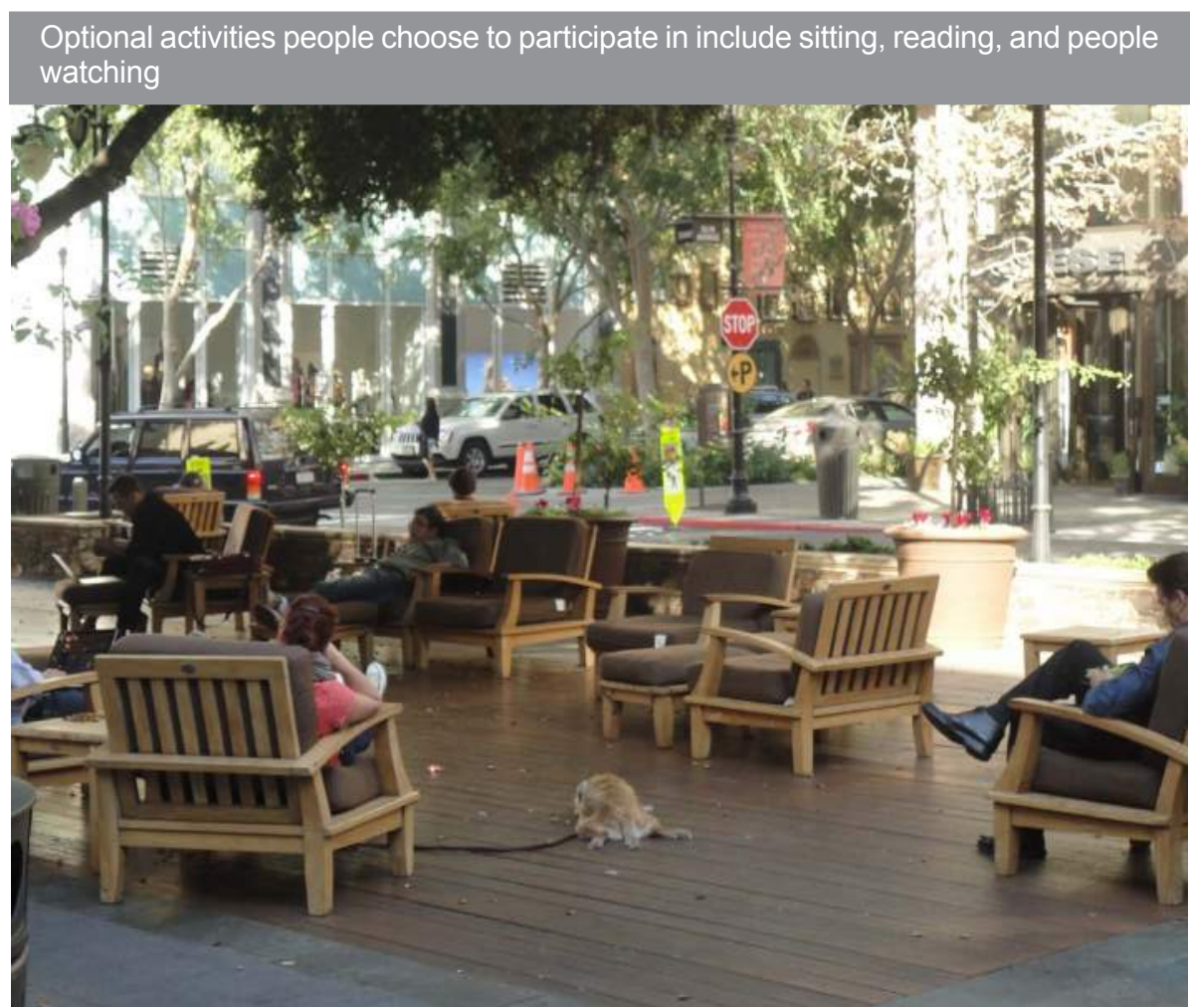


these activities.

Optional activities are those "participated in if there is a wish to do and if time and place make it possible" Carmona, Tiesdell, Heath \& Oc, 2010). These optional activities tend to take place in high quality designed environments where it is enjoyable to spend time, and where they feel invited to do so. Social activities are those that "depend on the presence of others in public space, such as greetings and conversations, communal activities of various kinds and passive contacts. These activities occur spontaneously as a direct consequence of people moving about and being in the same spaces, and are, therefore indirectly supported whenever necessary and optional activities are given better environmental conditions" Carmona, Tiesdell, Heath \& Oc, 2010).

The USDP should seek to improve conditions at University Square so that all three types of activities can occur. The necessary activities can include work, shopping, and waiting for the bus. The optional activities should include passive spaces where people can sit and relax and active spaces for people to engage in sports and activity. Social activities can be created through the provision of public spaces and pedestrian paths that intersect to allow people to meet and interact.

\subsubsection{Well Maintained Buildings and Public Spaces}

The development of new buildings and public spaces can greatly enhance or reduce the quality of the environment. Assuming that high-quality buildings and public spaces are constructed, it is imperative to the overall urban design success that they be well maintained. Poorly looked after buildings and spaces discourage people from using them and are often perceived as unsafe.

The authors of Public Places Urban Spaces argue, "a lack of proper maintenance can easily precipitate a spiral of decline," and that a high-quality public realm "requires a clean, healthy, and well-maintained environment" (Carmona, Tiesdell, Heath \& Oc, 2010). While the responsibility of public space maintenance often falls on the public sector, private organizations can also be involved as stakeholders, through legal agreements, coordination, planning, and checks and balances. While these devices are outside the scope the USDP, they should be considered further along in the urban design and development process.
2.2.6 Inclusion of Green Space

Open Space, or "Green Space" is an essential building block of good urban design. In his work City Building, John Lund Kriken argues that green space "may be the single most defining design element" in urban design (Kriken,2010). Green space helps to soften urban harshness, relieve the confinement of the built environment, encourage recreation, and even provide natural habitat for animal and plant species. Green space is often thought of as large-scale parks, watersheds, or migration corridors, but small-scale green spaces can also be created through extensive street landscaping, street trees, and pocket parks. Regardless of the scale, Kirken argues that green spaces should serve the function as the "natural center of civic life." At just over 8 acres, the University Square Site is not large enough to accommodate any large parks, migration corridors, or watersheds. However, the USDP should include an adequate amount of green space for exercise, walking, contemplation, picnics, and socializing, and should serve as the Sites natural center.

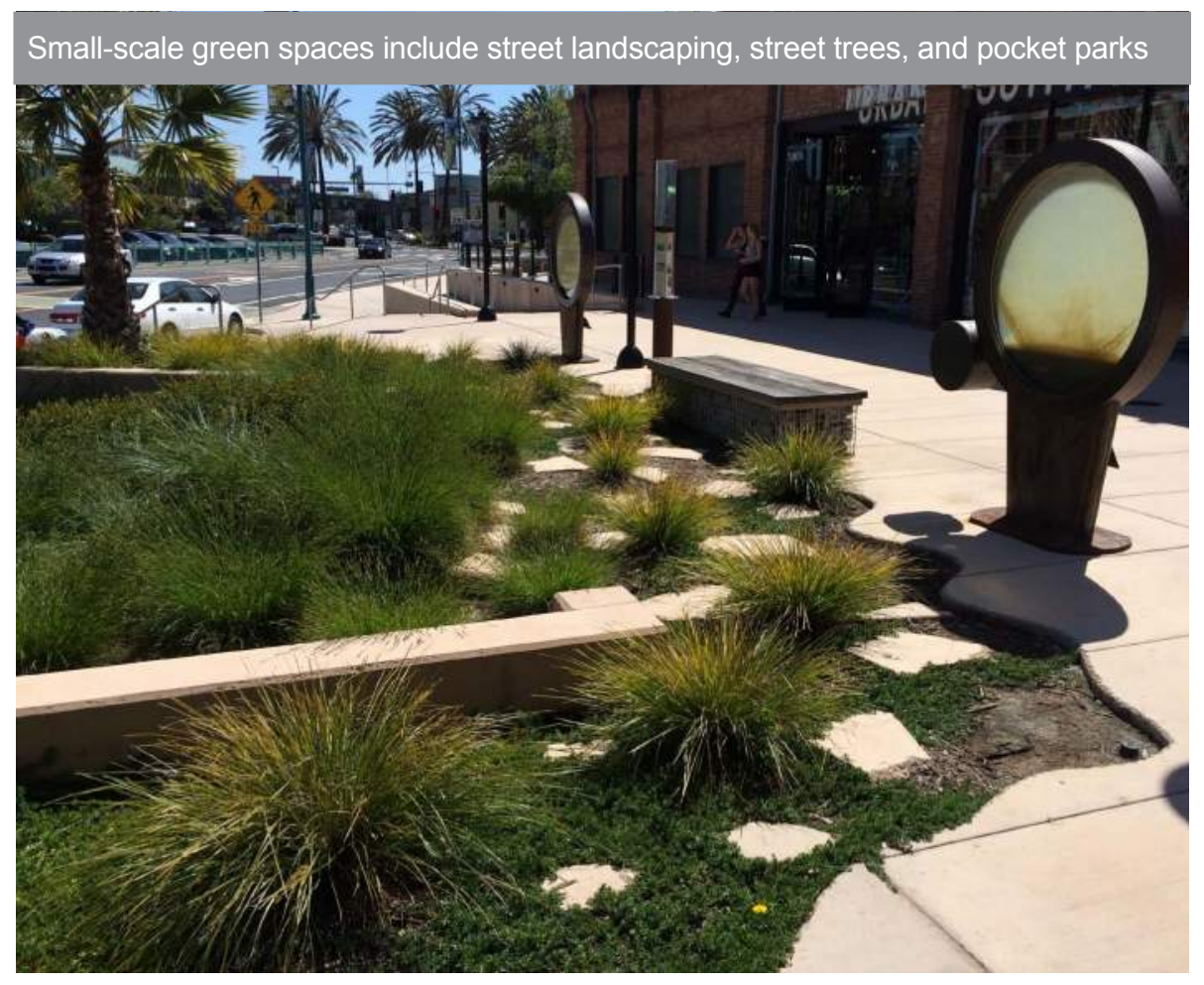




\subsubsection{Building Setbacks Close to the Street}

Building setbacks are the distance between the building and the street or sidewalk. In his work, New Urbanism, Peter Katz argues that for both residential and retail land uses, that building setbacks should be close to the street. For residential units he makes the following argument: "While conditions should vary throughout the neighborhood, houses should generally be placed close to the street in order to define its space" (Katz, 1994). This also encourages the development of balconies, porches, bay windows, and other semi-private attachments. For retail units Katz believes that there should be no setback whatsoever. "For retail buildings, the setback rule is straightforward: don't have one. Traditional retail, to be successful, must pull directly up to the sidewalk, so that people can see the merchandise in the window. Parking lots in front are of course forbidden: there is little that is more destructive to pedestrian life" (Katz, 1994).

The crux of Katz argument on setbacks is the end of that last sentence. Setbacks close to the street encourage pedestrian activity and feed into some of the other urban design principles discussed in this section such as

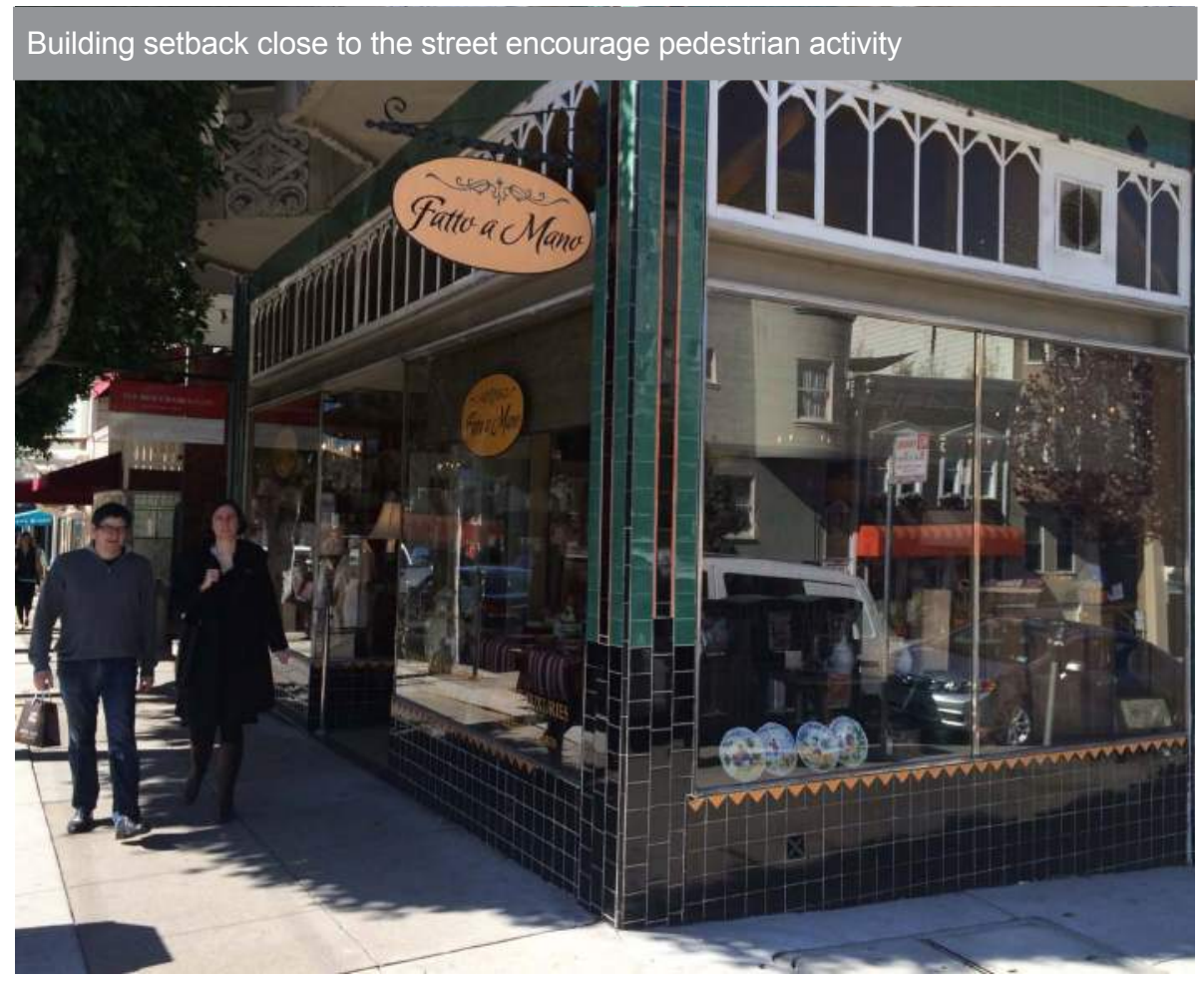

human scale and respect for the pedestrian. As we will see in Section 3, the Site currently has buildings with setbacks far from the street, surrounded by parking. The USDP should ensure that redevelopment at University Square does not follow this urban design typology, and instead follows the advice of Peter Katz with both residential and retail buildings setback close to the street.

\subsubsection{Unified Buillding and Natural Materials}

To convey a sense of high-quality design and permanence, building materials should be selected to simulate authentic and timeless materials. The selection and placement of building and natural materials should provide visual interest and enhance both buildings and public spaces. Uniformity in materials can help to create patterns and rhythm that enhances human scale and pedestrian orientation. In his work City Building, John Lund Kriken contends that urban designers can specify building materials to create a more "defined identity."

While building materials are important in establishing visual quality and continuity, the interrelationships of the buildings to landscaped spaces play an equally important role in establishing an area's character. Natural materials

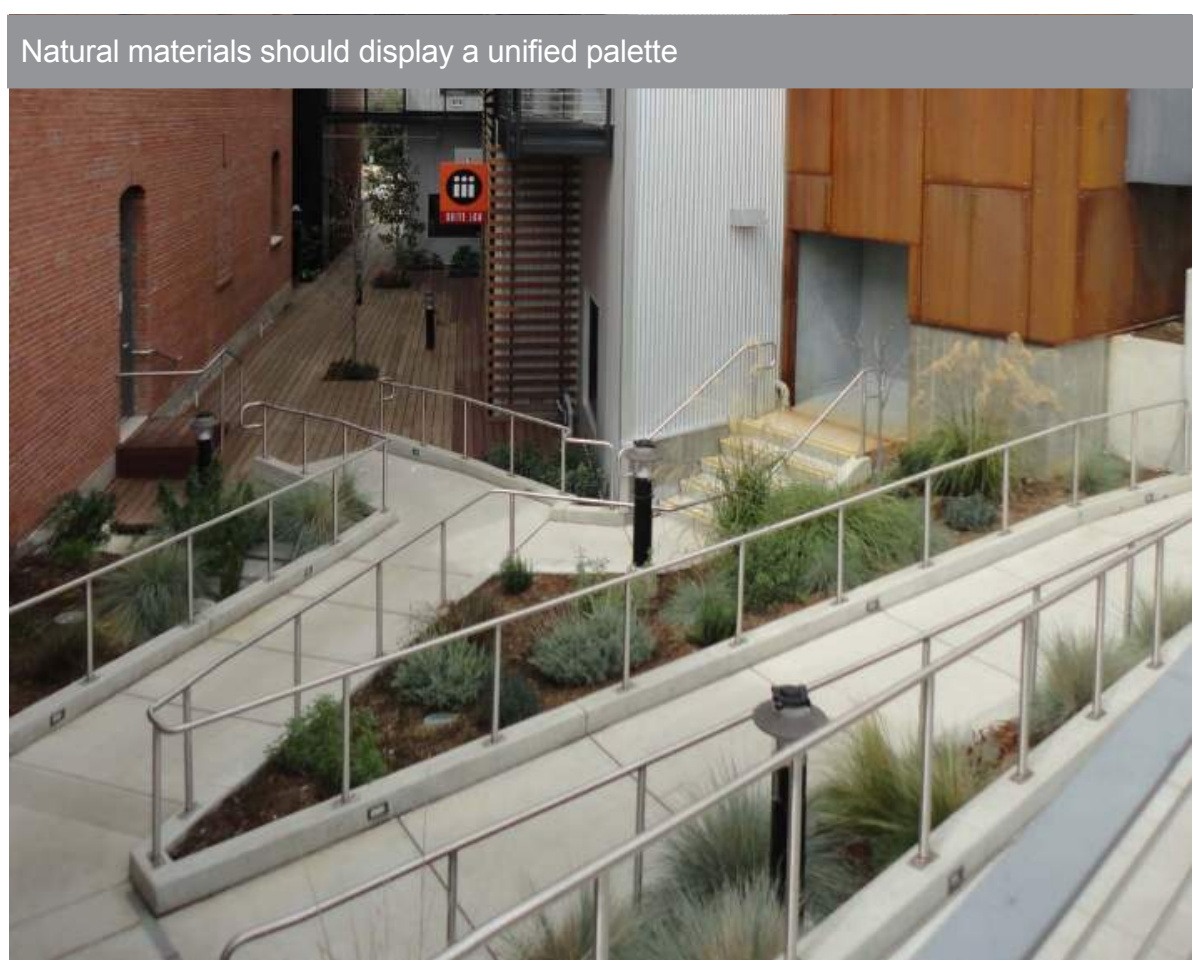


should be selected to display a unified palette and should enhance the overall development at University Square.

\subsubsection{Functionality}

Urban design's functional dimension relates to the actual operation of a place, or more simply put: how a place works. The authors of Public Spaces Urban Spaces, discuss five parts of the functional dimension of urban design that contribute to the effective functioning of a place: movement, 'people places', environmental design, healthy environments, and infrastructure.

Movement relates to the vehicular and pedestrian connections and flows. The two forms of movement are often distinctly different in that vehicular movement is pure circulation, whereas pedestrian movement permits "economic, social, and cultural exchange" (Carmona, Tiesdell, Heath \& Oc, 2010).

The authors describe the concept of the people place, as "those that are intended to be used by people, usually through spontaneous, everyday and informal use" (Carmona, Tiesdell, Heath \& Oc, 2010). Some public spaces are effective people places, such as Union Square in San Francisco, and others are not, such as City Hall Plaza in Boston. What defines a successful people place is tricky, as people places are characterized by people, in a somewhat self-reinforcing progression. However, the authors point to five (5) key attributes that define a people place: comfort and image, access and linkage, uses and activity, and sociability.

Environmental design refers to the creation of comfortable conditions within spaces. This is achieved by designing in relation to natural influences such as sunlight, shade, temperature, humidity, wind, and noise. Each of these has a distinct effect on the enjoyment of a place, and when taken into account early in the design process can be effectively planned.

Healthy environments refers to the overall concept of urban design playing a role in the physical, mental and social well-being of people. Effective urban design can promote public health, while poor design can hinder it. For example a poorly designed road network can lead to congestion, increasing air pollution and choking the air with noxious fumes. This can lead to respiratory problems and diseases such as asthma, emphysema, and bronchitis. On the other hand, good urban design can provide healthy spaces that provide people the choice to recreate, play,
Infrastructure often plays a less visible role in the effective functioning of a place, but it is no less important than any of the previously mentioned parts of functional urban design. Infrastructure is made of "above and below ground elements" Carmona, Tiesdell, Heath \& Oc, 2010) such as roads, sidewalks, power lines, wastewater, irrigation, parking, and a range of other infrastructures. The availability of infrastructure is a key component in where development occurs, and is crucial to place making. The authors argue that urban design projects can reduce the need for new infrastructure, by designing with what already exists, through careful site analysis and planning.

\subsubsection{Connections and Permeability}

Connections and permeability in urban design describes the relationship between urban form and the movement of people, and usually refers to pedestrian and vehicular connections and networks. In The New Urbanism, Peter Katz describes the New Urbanist theory of connectivity: "If a new neighborhood is to contribute more to the its region than traffic, it must do more than just mix uses. Its relationship to its neighbors is important as well. In order to avoid the inefficient hierarchical street pattern of sprawl, in which

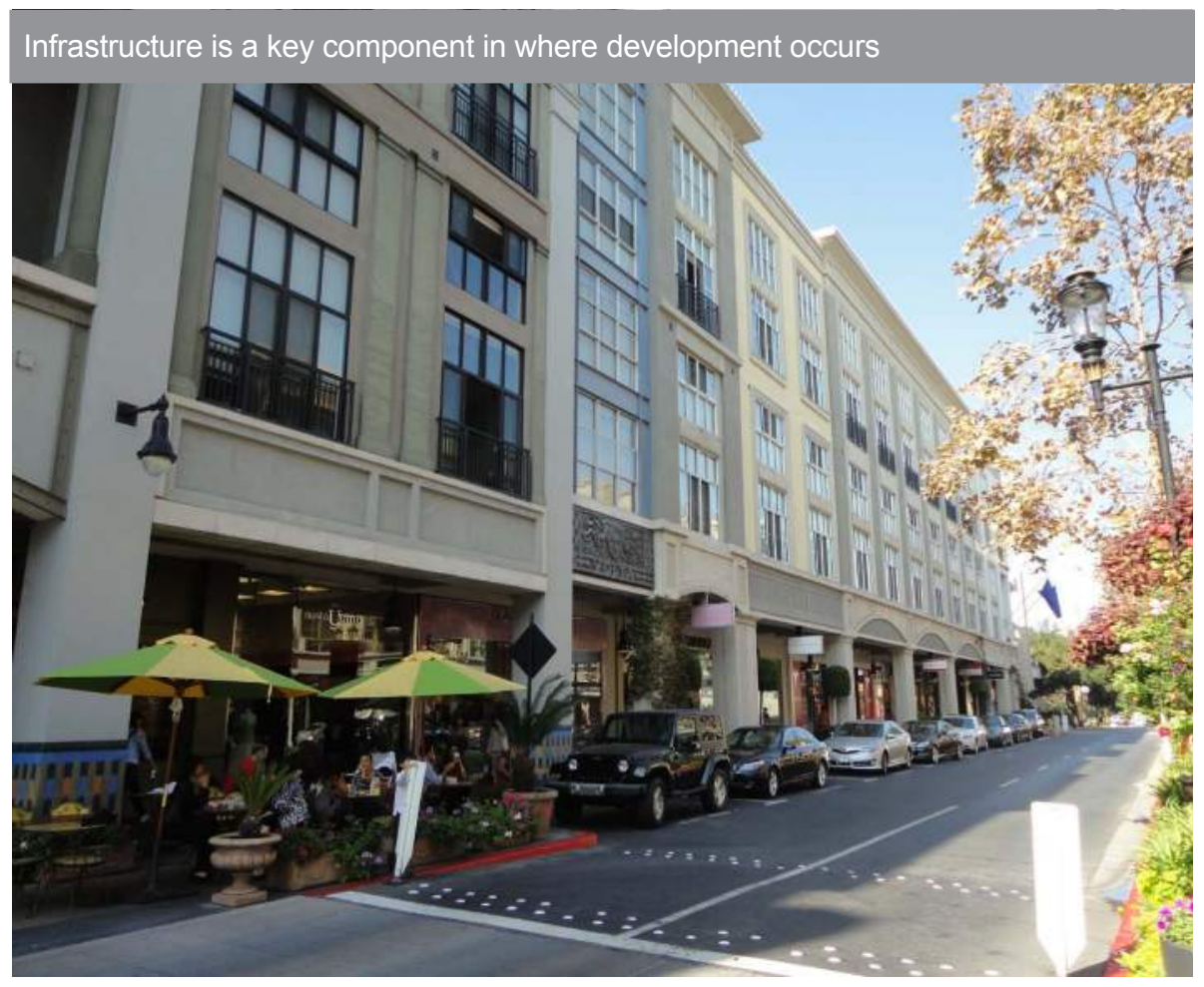


virtually every trip uses the same few collector roads, the new neighborhood must connect where practical to everything around it, even if its neighbors are nothing but single-use pods" (Katz, 1994).

Pedestrian connectivity and permeability is of upmost importance in urban design, so that pedestrian movement is made the easy choice. However, this can be difficult because pedestrian travel is rarely single purpose. A clear connection between public and private spaces is thus necessary. As the authors of Public Places Urban Spaces argue, "the continuity of urban space - the connections between destinations - is important and successful people places must be (and are) integrated with and embedded in local movement systems" " (Carmona, Tiesdell, Heath \& Oc, 2010). This is not to say that pedestrian and vehicular movement cannot exist side-by-side. On the contrary the two can coexist seamlessly if designed intentionally and with the pedestrian point of view in mind.

Good urban design should provide for connections and permeability from public space to public space. This often means creating mid-block connections with arcades, alleys, and paseos. The USDP should avoid a design that lacks any mid-block connections, and should seek to provide a legible environment with clear connections and permeability.

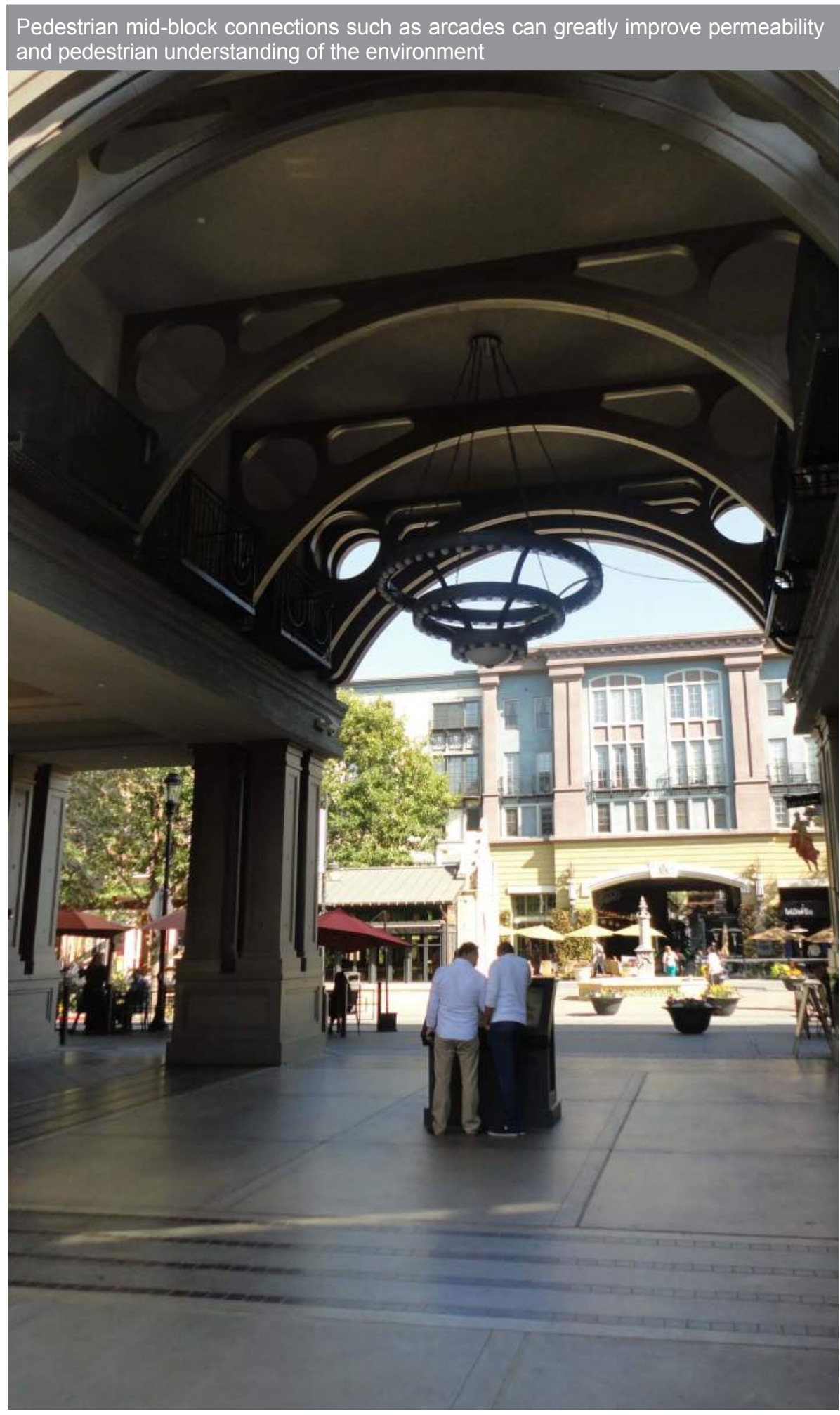




\subsection{MIXED-USE DEVELOPMENT PRINCIPLES}

While the previous section focused on urban design, and the role that it plays in the development process, this section will specifically focus on the factors that contribute to a successful project and advantageous financial outcomes. The USDP aims to create a financially viable proposal for the University Square Site, and this Literature Review consolidates mixed-use development processes, objectives, and principles into the "Mixed-Use Development Matrix;" a diagnostic chart with seven categories that can be used to evaluate good mixed-use estate development projects and practice. This Literature Review examines four bodies of work: The Mixed-Use Development Handbook by Dean Schwanke, Real Estate Development Principles and Process by Mike Miles, Richard Haney, and Gayle Berens, Real Estate and Urban Development by Halbert Smith, Carl Tschappat, and Ronald Racster, Urban Planning and Real Estate Development by John Ratcliffe, Michael Stubbs, and Miles Keeping.

The review and analysis of the four works on real estate development has illuminated best practices and good principles in the profession. Those that appeared at the forefront include: defining clear objectives for the project, determine the "cornerstone use" for the project, treating the public sector as a partner from the outset of a project, understanding the market, creating value for investors, sustainability, and making sure that there is an availability of funds. Figure 2.3: The Mixed-Use Development Matrix arranges these principles into a table that can be used to evaluate good real estate development projects and practice. The Mixed-Use Development Matrix contains the real estate development principles in rows and the score measurement in columns. The maximum score that a case study or project can receive is 14 points, while the minimum is 0 points. Case studies with $10-14$ points can be considered to exhibit good mixed-use development qualities, while those with 5-9 points can be considered to exhibit fair mixed-use development qualities, and those with less than 4 can be considered as having poor mixed-use development qualities.

\subsubsection{Clearly Defined Objectives}

By its very nature mixed-use development is complex and challenging. Clearly defined objectives for projects helps provide guidance during the
FIGURE 2.3 - The Mixed-Use Development Matrix

\begin{tabular}{|c|c|c|c|}
\hline $\begin{array}{c}\text { Mixed-Use } \\
\text { Development Principle }\end{array}$ & Good (2) & Fair (1) & Poor (0) \\
\hline $\begin{array}{l}\text { Clearly Defined } \\
\text { Objectives }\end{array}$ & & & \\
\hline Cornerstone Use & & & \\
\hline $\begin{array}{l}\text { Public Sector Treated as } \\
\text { a Partner }\end{array}$ & & & \\
\hline $\begin{array}{l}\text { Understanding the } \\
\text { Market }\end{array}$ & & & \\
\hline $\begin{array}{l}\text { Create Value for } \\
\text { Investors }\end{array}$ & & & \\
\hline Sustainability & & & \\
\hline Availability of Funds & & & \\
\hline
\end{tabular}

development process and allows the developer to keep her eye on the prize. In his work Mixed-Use Development Handbook, Dean Schwanke speaks to the importance of clearly defined project objectives: "Both financial and non financial development objectives must be well defined and well understood from the outset. The nature and relative importance of these objectives will help shape the project, and as planning and development continue, all decisions will be tied in one way or another to these initial objectives-either in their conformance to the spirit of the objectives, or as feedback leading to a reassessment of the initial objectives" (Schwanke, et al. 2003).

Schwanke importantly notes that project objectives are flexible, and that they can be redefined with changing realities. He also notes that sometimes the most important task is to make explicit the non financial objectives of the project, so that "their effect on the project's financial performance can be estimated, understood, and justified" (Schwanke, et al. 2003). These non financial objectives also confirm to other stakeholders the non-monetary intentions of the developer, and can help lead to mutual understanding. It will be key that during the development of a program for the USDP that a set of non financial objectives is explicit and clearly defined. These should feed into the overall financial objective of the USDP to create financially viable proposal for the University Square Site.

\subsubsection{Determining the Cornerstone Use}

Another concept from the Mixed-Use Development Handbook that is of major importance to the USDP is "determining the cornerstone use" (i.e. "the one in the project that is most viable and profitable" (Schwanke, et al. 2003). In a 
mixed-use development project the cornerstone use often becomes the driver of the overall development concept and will also determine "the suitability and compatibility of other uses" (Schwanke, et al. 2003). Schwanke discusses the merits of different types of cornerstone such as retail, office, hotel, and entertainment. He argues that there is not a one-size fits all approach in this determination and that each development context is unique.

The primary driver for the USDP remains the residential student housing, which will serve as the largest use on the site. However, residential is not always the most profitable use, and office or retail may end up as the largest revenue generator and emerge as the cornerstone use. Regardless of which use ends up as the cornerstone, the USDP will seek a balance and compatibly between all uses on the Site.

\subsubsection{Treating the Public Sector as a Partner}

The authors of Real Estate Development Principles and Processes argue that the public sector is always a partner in every development project. Not only is the public sector a stakeholder with valid interests, the public sector also

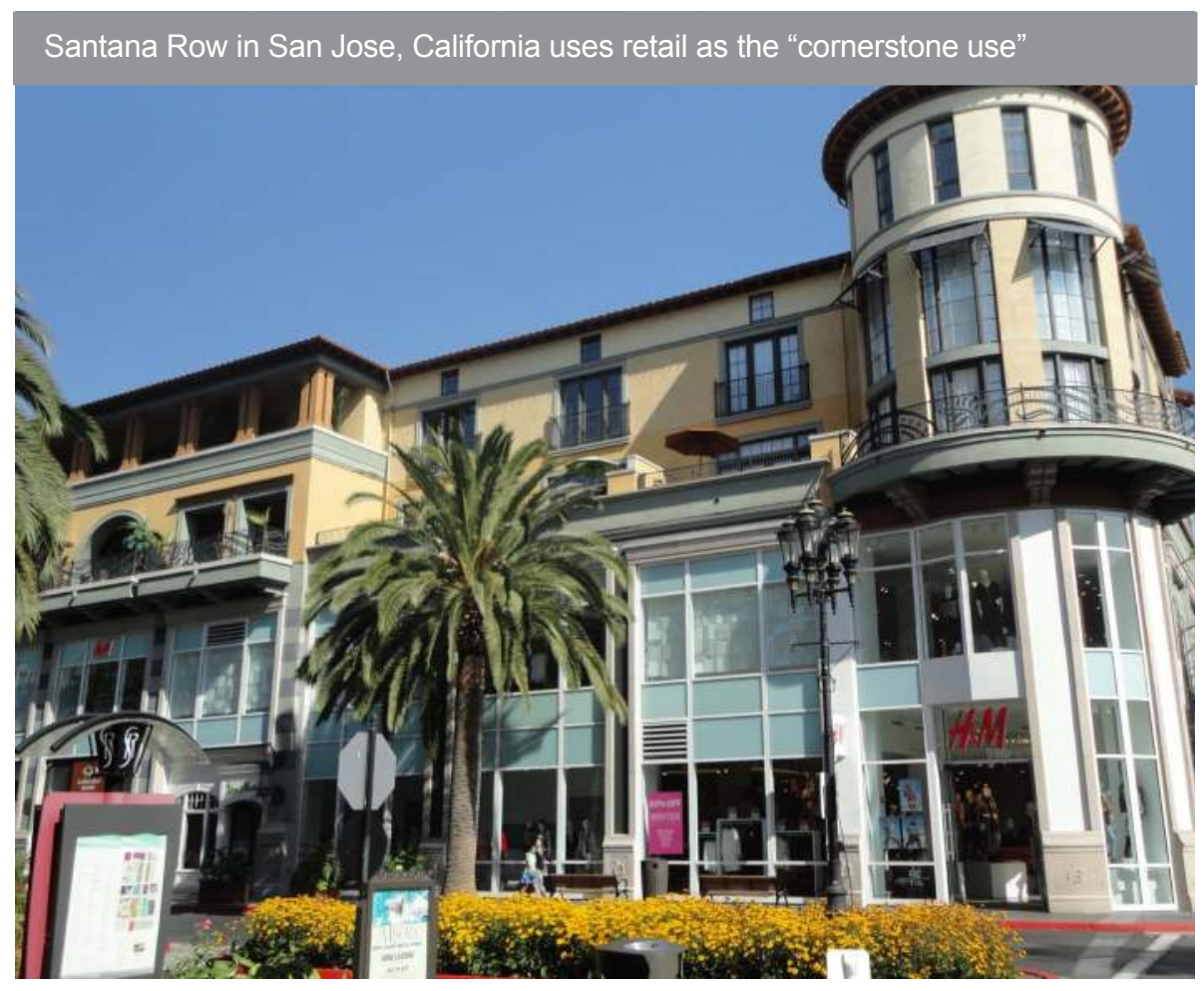

has the ability to derail a project: "if developers do not work hand in hand with local governments, giving them the same amount of respect and attention they would give a private sector partner, delays and problems may occur" (Miles, Haney, Jr. \& Berens, 1996). In fact, they argue that changes and delays caused by the public sector can make a project infeasible. Thus it is important to treat the public sector as a partner.

This is an especially important concept to consider when making propositions within the USDP, as the decisions made are constrained and to a certain extent dictated by local governance and law. This also means not overlooking the people in the neighborhood that are adjacent to the University Square site, who are effected by any outcomes from the project and can petition local government on their own behalf.

\subsubsection{Understanding the Market}

The authors of Real Estate Development Principles and Processes also discuss the importance that market research plays in a projects success. The "market" is defined as "both users of the type of property and as buyers and tenants located in a geographic area" (Miles, Haney, Jr. \& Berens, 1996). The understanding of the market (both users and buyers) is critical to the success or failure of a project. As was seen in Figure 2.1, a market assessment is undertaken as a part of the USDP.

The market assessment should evaluate the need of the customer, and University Square Development should look to satisfy the "human wants and needs" (Miles, Haney, Jr. \& Berens, 1996) of the target market. These wants and needs can be thought of as the traditional real estate measurements such as quality, features, options, layout, finishes, and amenities, but can also refer to the human needs for socializing and relaxation. The USDP will seek to evaluate the wants and needs of the target market, and will examine the local market to see how the USDP can outperform its competitors who may not fully be meeting the markets wants and needs.

\subsubsection{Create Value for Investors}

Like any investment, mixed-use development should seek to create value for its investors. Real Estate and Urban Development discusses value creation as a central idea in real estate development. This is important to keep in 
mind when looking for financing for a project, as investors who have a range of investment options.

The authors describe the mind-set that is needed when making decisions in development: "the approach to decision making should be based upon the premise that many alternatives are available to the investor" (Smith, Tschappat \& Racster, 1977). While the primary purpose of redeveloping the University Square Site remains University housing, creating value for investors will drive the projects financial prospects.

\subsubsection{Sustainability}

In Urban Planning and Real Estate Development the authors discuss sustainability as an integral factor in the mixed-use development processes. The authors contend that development sustainability goes beyond the regulatory issue, and is a theme that "cuts across every aspect of the work of property developers, because those who fund, purchase and occupy them, as well as those who build them and provide the necessary financial advice, increasingly require sustainability issues to be fundamental" (Ratcliffe, Stubbs \& Keeping, 2009).

Sustainable development includes strategies such as green roofs, green streets, bio-retention basins, and photovoltaics, but it also has to do with the general design, construction, and investment of the building. From an investment standpoint, sustainability affects the obsolescence risk of a building, and environmental issues considered as components of prime property. During the development of the USDP sustainability issues need not be an afterthought but should inform the entire decision making process.

\subsubsection{Availability of Funds}

Another topic discussed in Urban Planning and Real Estate Development is the sourcing development financing. This discussion is essential to every development project and can be fairly complex. Funding sources that the book identifies include insurance companies and pension funds, banks, trusts and bonds, internal finance, the construction industry, property companies, government, and the financial markets. Though the USDP will look towards Cal Poly as a funding partner, there is likely to be deficient funds and alternative financing sources need to be considered further along in the development process. 


\section{SITE ASSESSMENT}

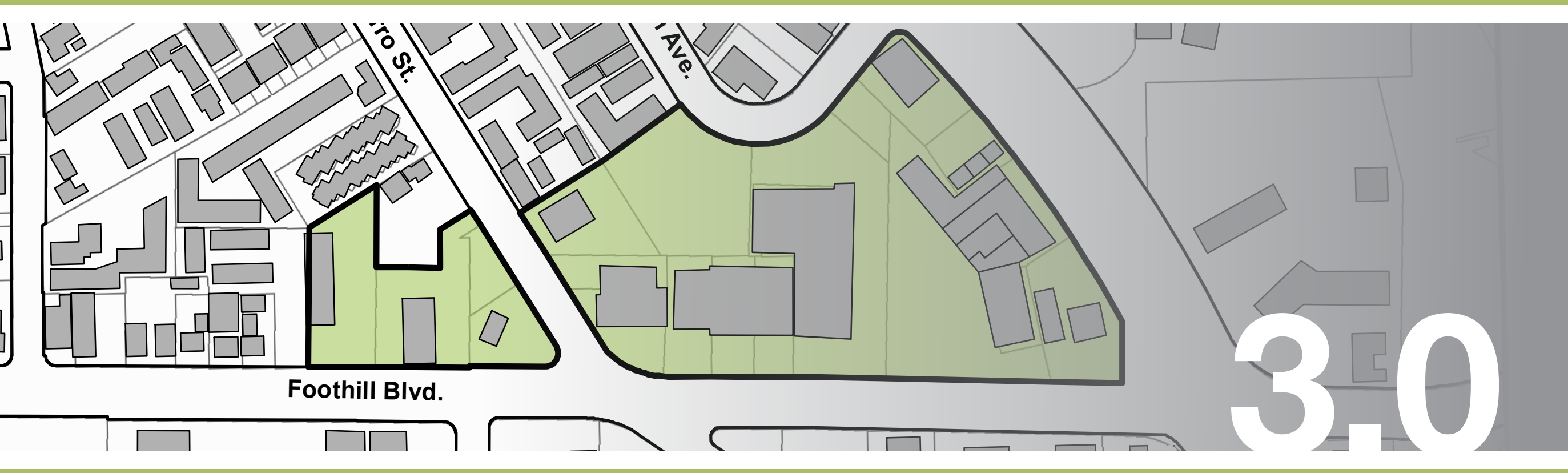


THIS PAGE INTENTIONALLY LEFT BLANK 


\subsection{SITE ASSESSMENT}

This Section provides a context-specific inventory and analysis of the University Square Site's physical, biological, and cultural attributes. This includes zoning and regulations, neighborhood character, existing structures, circulation, utilities, topography and soils, hydrology and drainage, climate and solar orientation, the local market, and sensory perception. The intent of this analysis is to provide clear opportunities and constraints for the design and development of University Square Site.

\subsection{SITE LOCATION}

University Square (the Site) is located in the City of San Luis Obispo, California. Nicknamed "SLO," the City sits approximately 201 miles north of Los Angeles, and 232 miles south of San Francisco. The City serves as the County of San Luis Obispo's political seat as well as the regional center for entertainment and commerce. Surrounded by low hills and fertile agricultural land, the City of San Luis Obispo has warm summer months and mild winters, with average annual temperatures between $49^{*}$ and $69^{*} \mathrm{~F}$ (CA NCDC, 2010). With its location in the heart of the Central Coast wine country, the City attracts visitors and tourists, and is favored by regional economic and employment patterns. The City's 12.39 square miles is more densely populated than surrounding cities in San Luis Obispo County at approximately 3,642 persons per square mile. This is largely due to three factors: the City's concentration of regional jobs, the City's dense development patterns, and the City's proximity to Cal Poly. According to the 2010 US Census the City of San Luis Obispo has an estimated total population of 45,130 persons, and a median age of 24.5 years (U.S. Census, ACS 2011, 5 year). Graph 1.1 shows the age distribution for the City by sex and age cohort. The dominant age cohort, 20-24 years, accounts for approximately 31 percent (31\%) of the City's total population, mainly due to the City's proximity to Cal Poly and nearby Cuesta College.

TABLE 3.1 - San Luis Obispo Age Distribution. Source: US Census, American Community Survey 2012, 3-year estimate

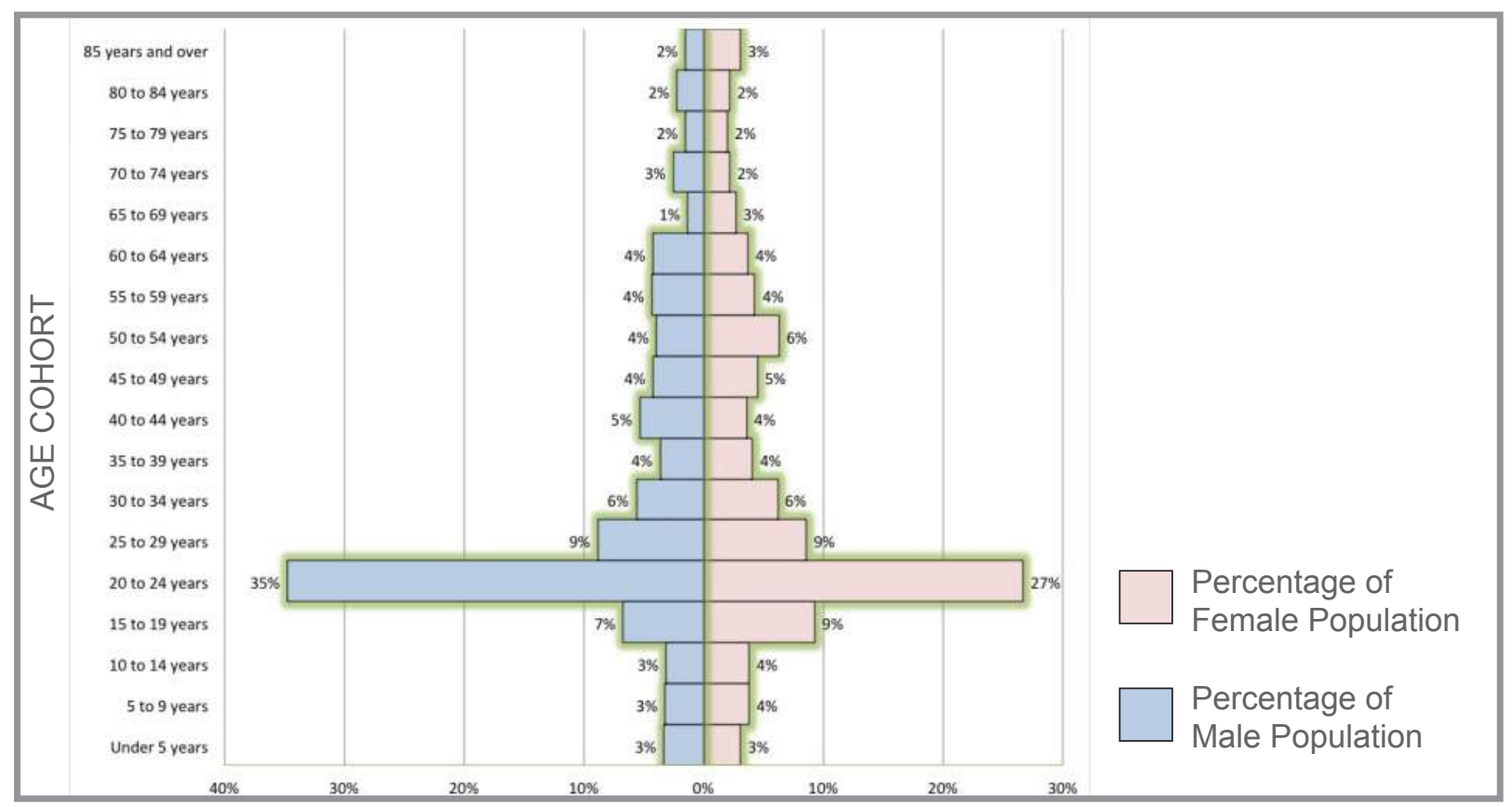

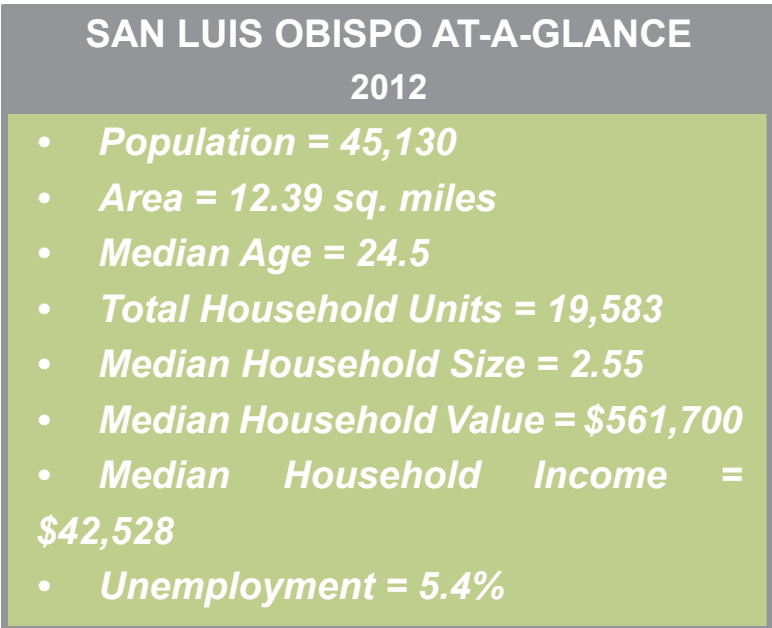




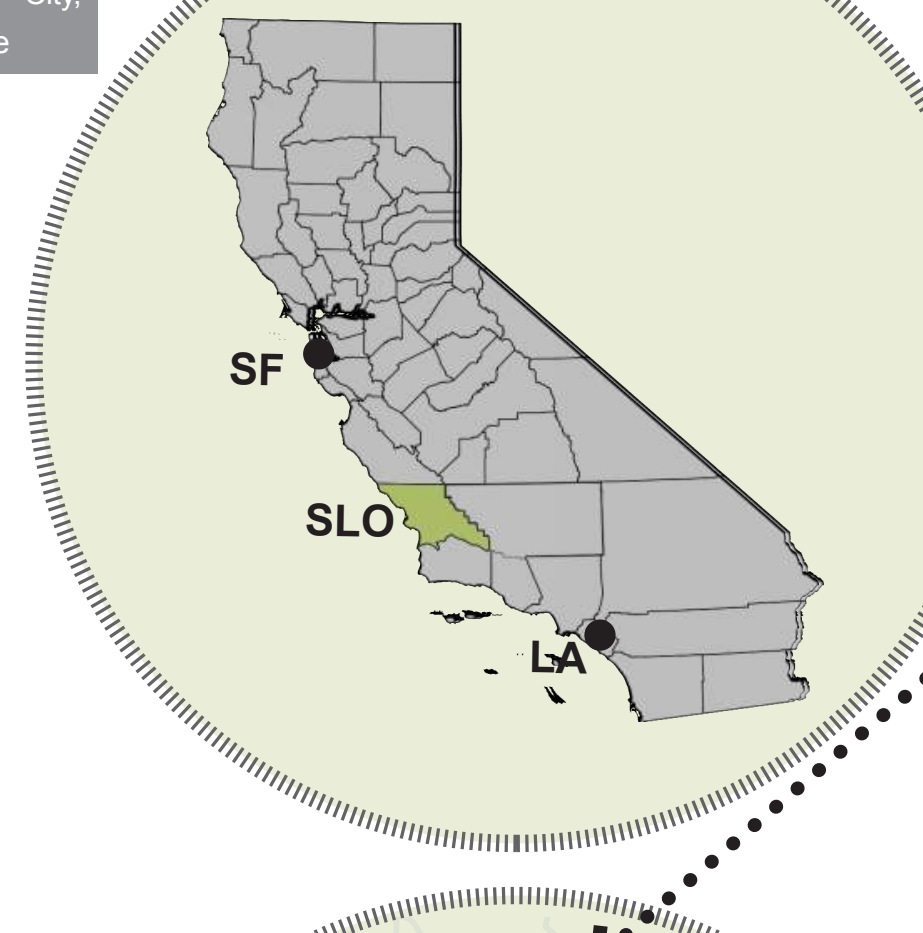

STATE ....!!!!!

$\rightarrow$ COUNTY

County, and State

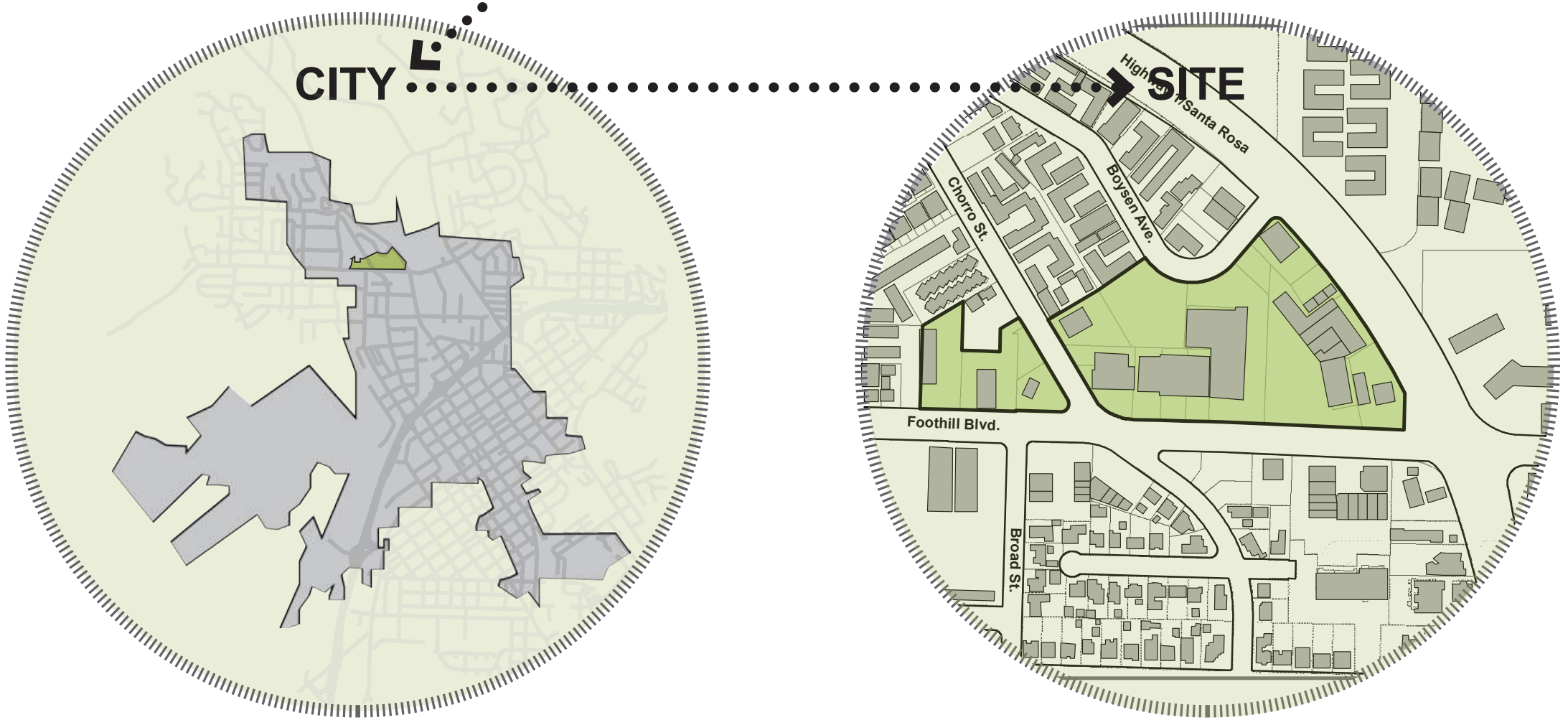


The Site occupies 8.2 acres in the northern portion of the City in close proximity to Cal Poly. The Site is bounded by Highway 1/Santa Rosa Street to the east, Foothill Boulevard to the south, and Chorro Street, Broad Street, and Boysen Avenue. Figure 3.1 shows the University Square Site in relation to the City of San Luis Obispo, the County of San Luis Obispo, and the State of California. The Site was originally developed in the 1950's as a neighborhood serving commercial center that mixed small retail establishments and a large grocery store anchor. Like many commercial "strip centers," University Square has become run-down and dysfunctional. New Frontiers Grocery, the last major tenant to occupy the Site left in 2010 . Other large and small tenants have left, leaving only 60 percent $(60 \%)$ of the buildings occupied. Figure 3.3 shows the main dimensions of the site, as well as the square footages of buildings.

While the commercial liveliness of the center has declined, the Site remains an ideal location. Figure 3.2 shows that the distance between the Site, and both Downtown San Luis Obispo and Cal Poly is less than one mile, making it an ideal location to walk or bike to and from. Additionally, the Site's key location on the southern end of scenic Highway 1 makes it a defining gateway into the City that remains highly visible to both residents and visitors.

FIGURE 3.2 - Distance and Average Walking Times between University Square, Downtown SLO, and Cal Poly

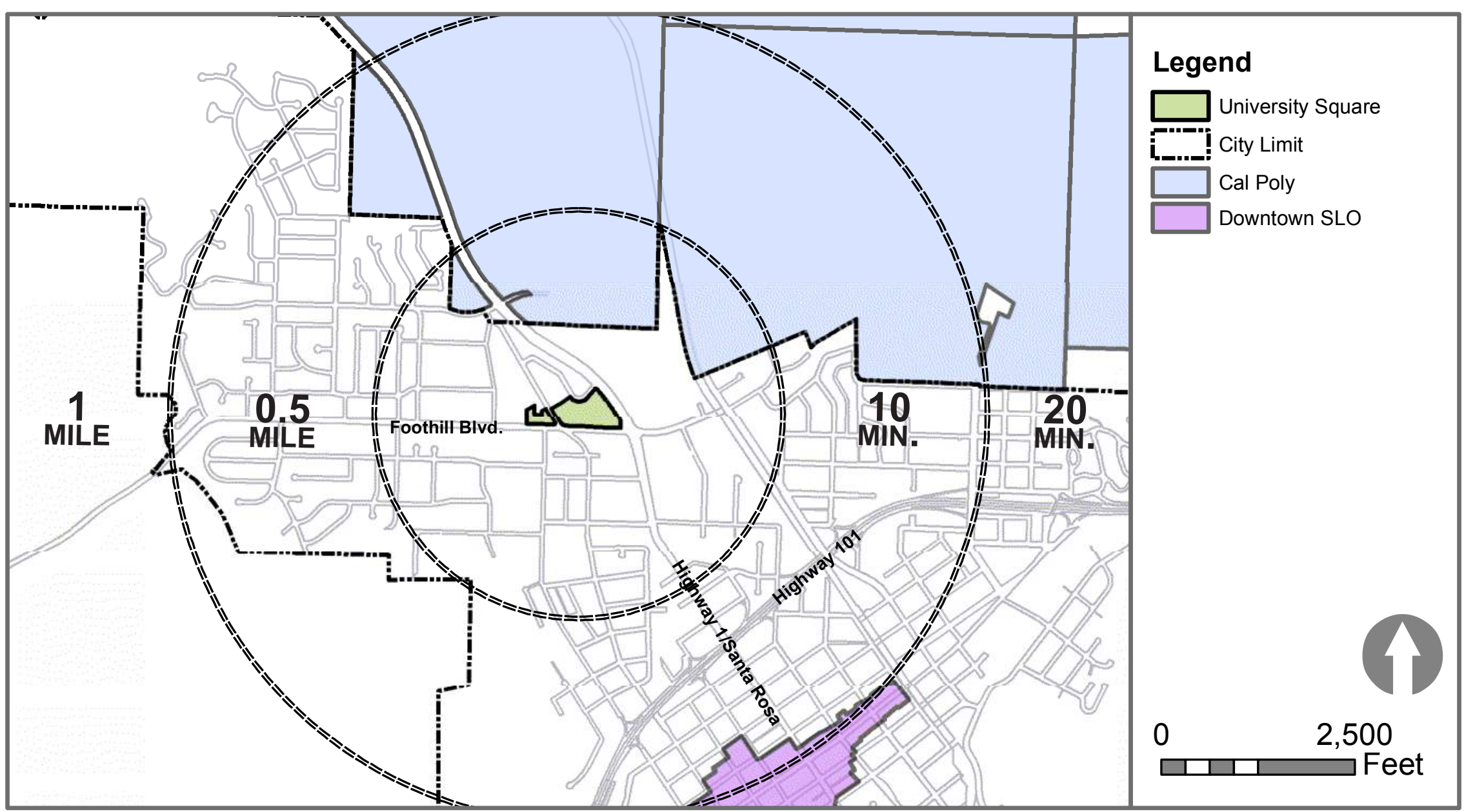




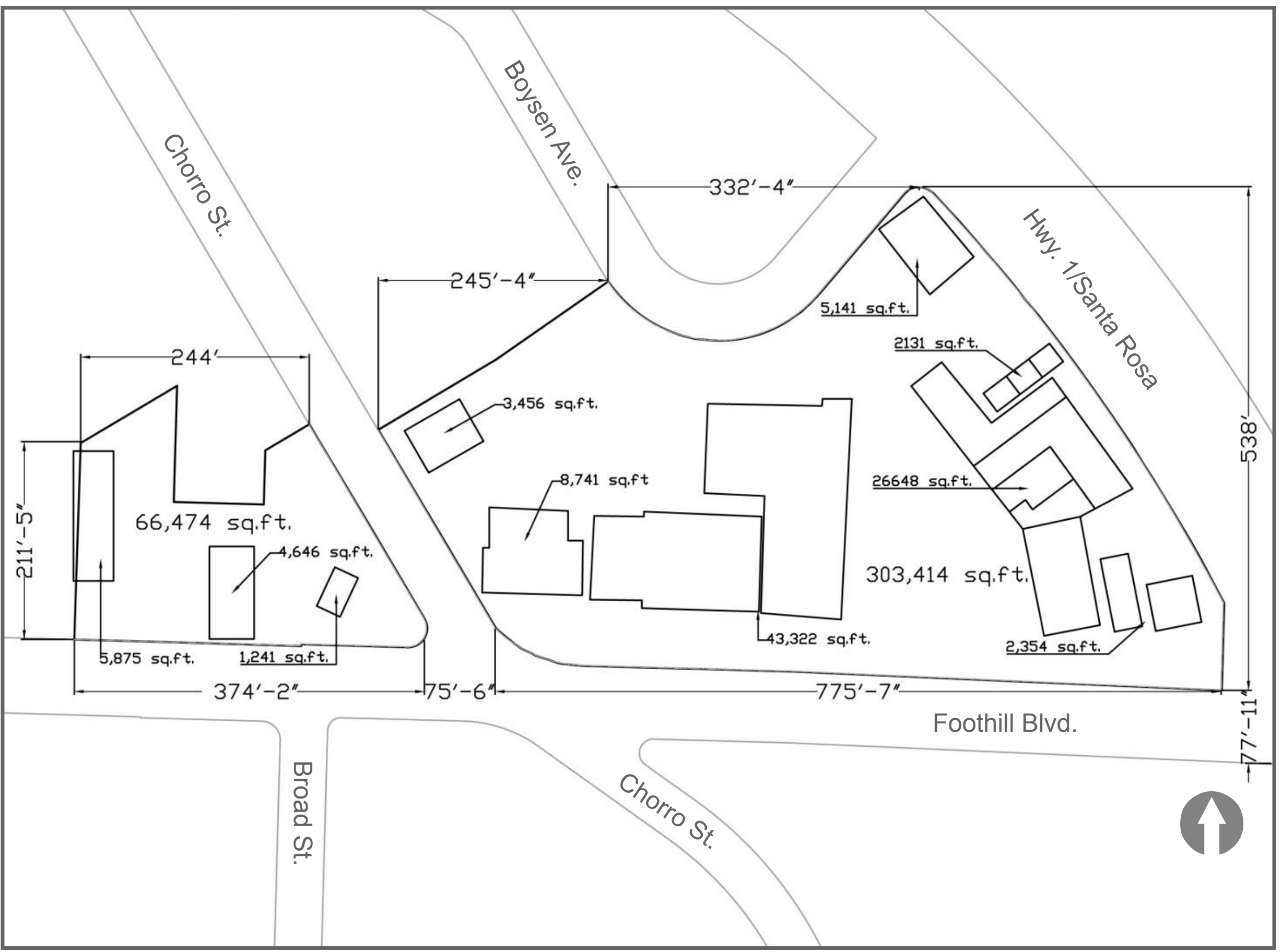




\subsection{NEIGHBORHOOD CHARACTER AND CONTEXT}

To a certain extent, the neighborhood surrounding the University Square Site is described by its zoning and land uses. However, these factors only partially account for the local context under which redevelopment will take place. It is important to understand the relationship between the mass and space on the University Square Site, and how it relates to the surrounding community. Figure 3.4 is a figure-ground map of the area, and shows the relationships of the building masses (in black) and the open space and rights-of-way in white. This diagram shows that the current building massing on the Site is disjointed from its surrounding, and fails to define the block pattern established in the adjacent neighborhoods. The buildings also fail to relate to one another and provide little street frontage.

Figure 3.5 shows local resources in close proximity to the Site. These include Bella Montana faculty housing, Pacheco Elementary School, The Church of Jesus Christ of Latter-day saints, The Villages of San Luis Obispo senior housing, Mustang Village student apartments, Zion Lutheran Church, and Sierra Vista Regional Medical Center. These local resources contribute to the local context and provide key adjacencies to the Site.

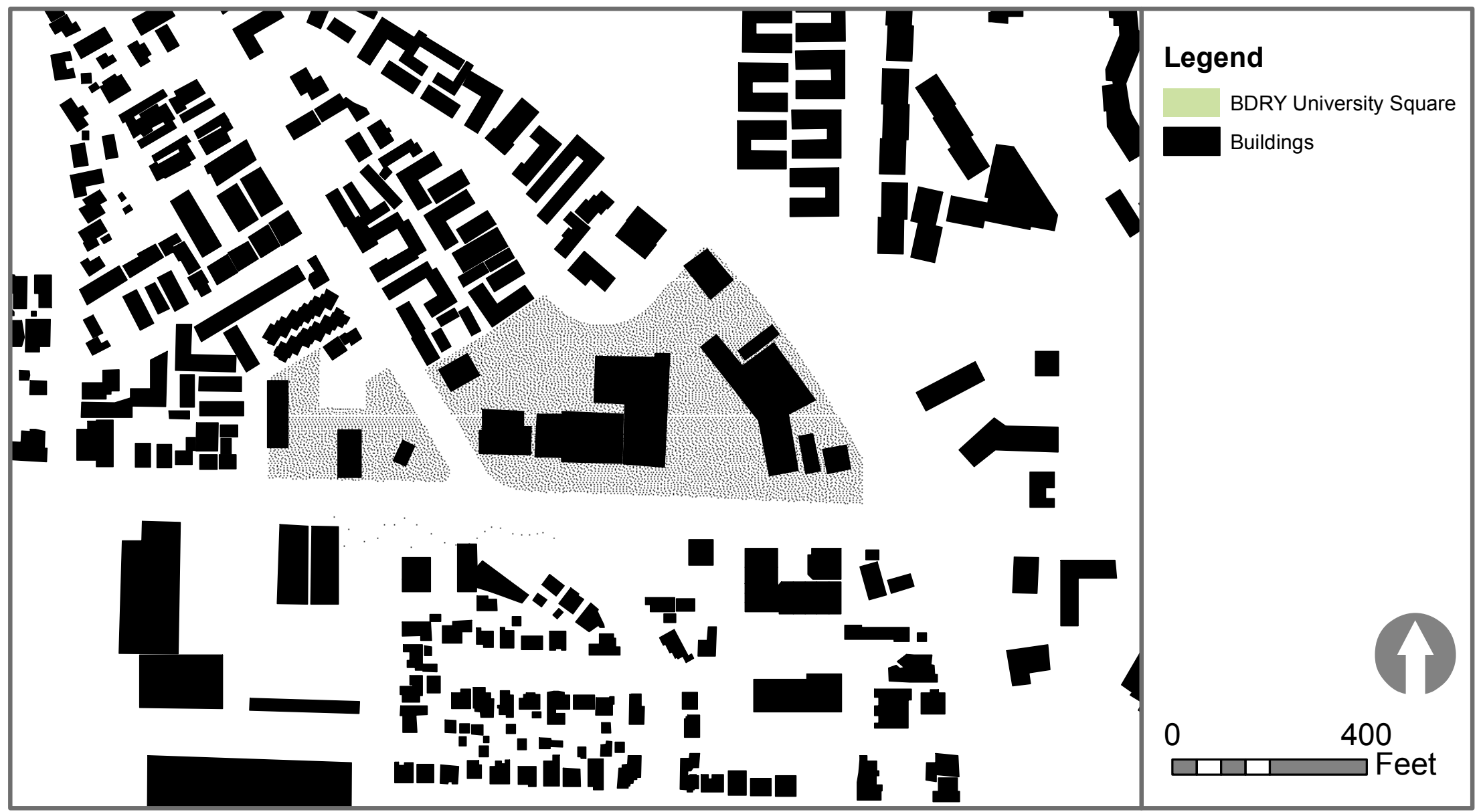



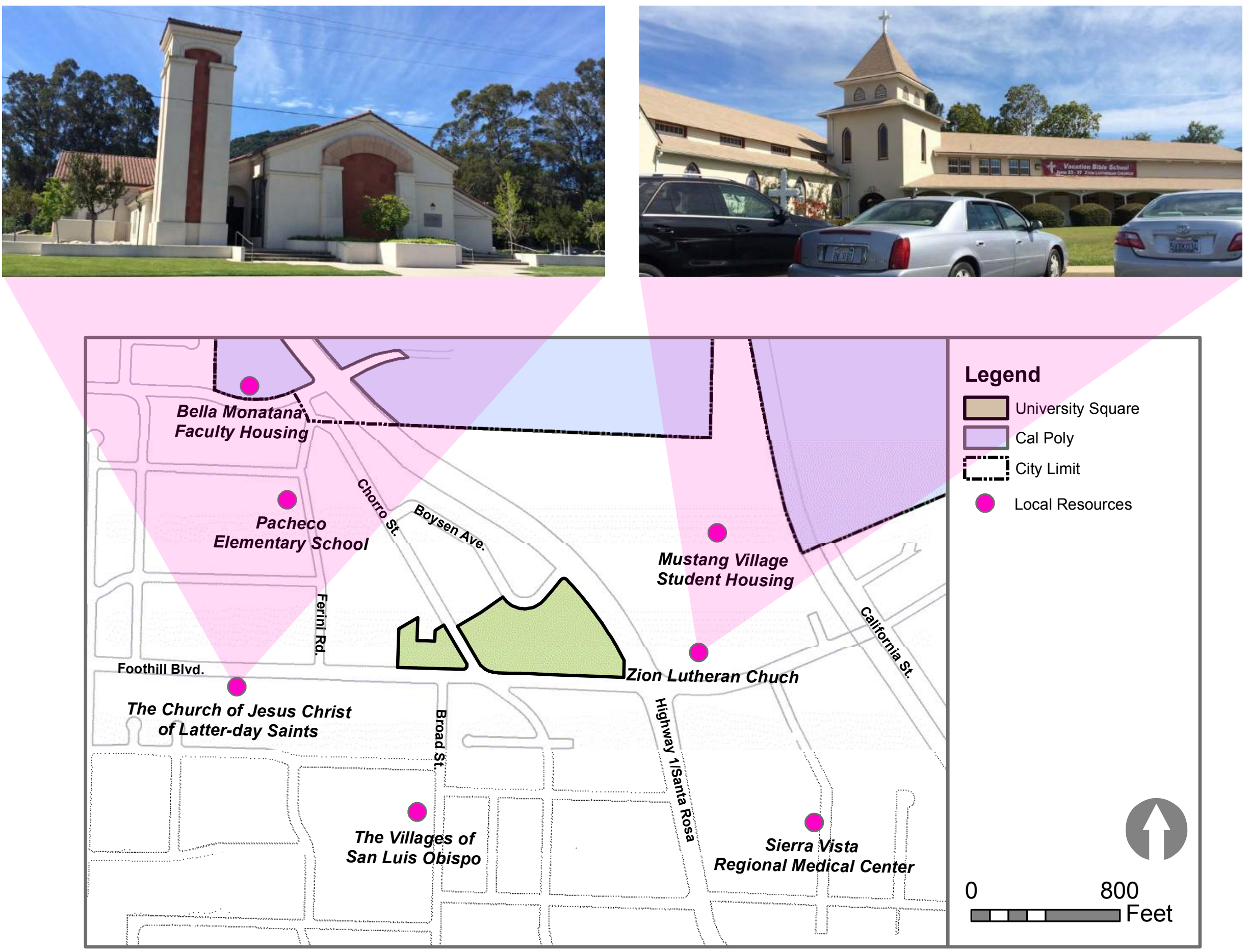


\subsection{EXISTING STRUCTURES}

The University Square Site consists of nineteen (19) separate parcels, and ten (10) separate structures. Many structures overlap parcels, and several of the structures contain multiple businesses. Figure 3.6 provides numbering for the twelve structures, while the remainder of this Section provides a general assessment and evaluation of each structure.

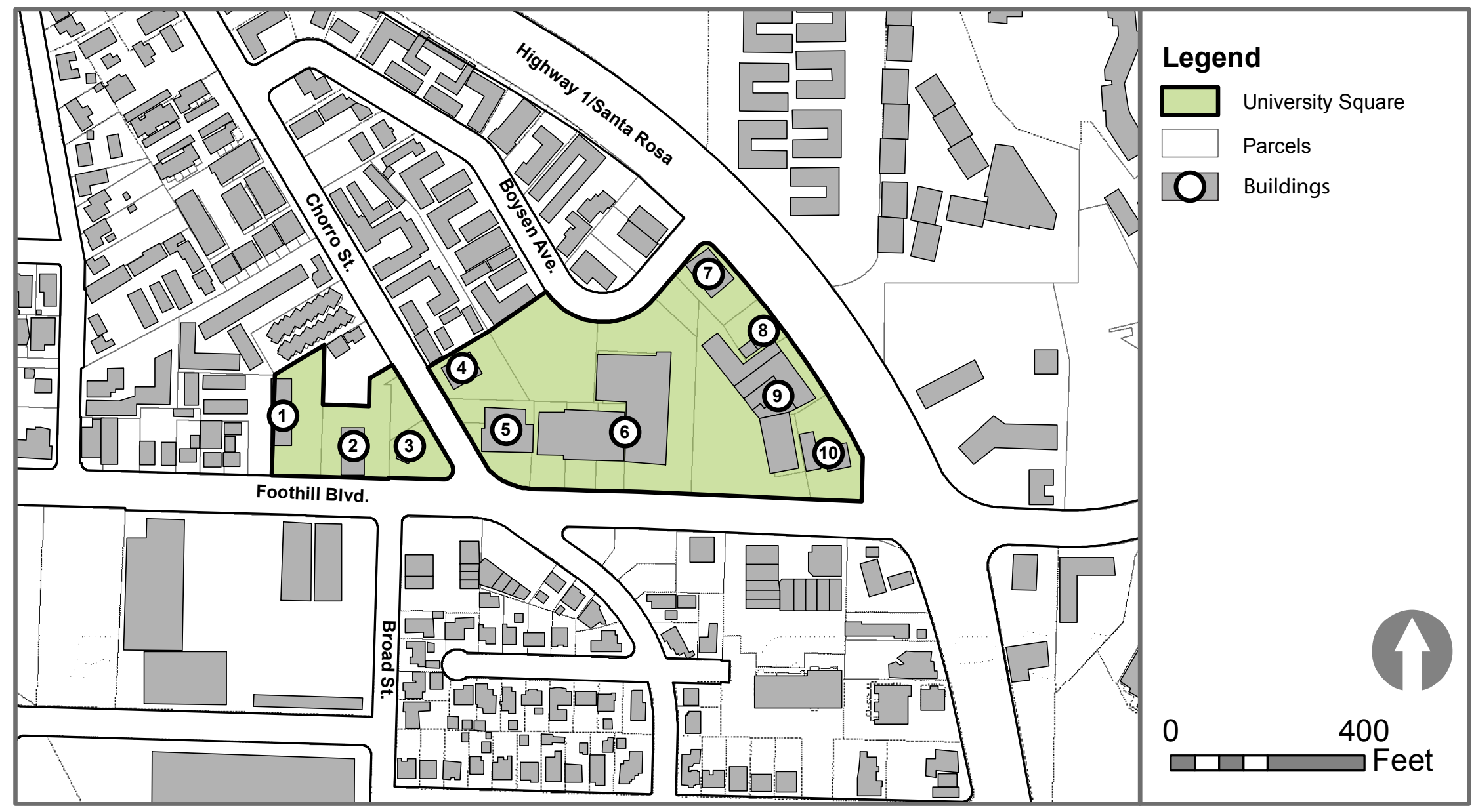


Structure 1 currently houses the Cork $\mathrm{n}$ Bottle Liquor Store. The structure looks like it was build during the 1960's or 1970's and has the strip center architecture that was typical of that time. The structure would not be worth saving during redevelopment of the Site. General Characteristics of the structure are as follows:

Redevelop: Yes

SQ Footage: 5,875 sq. ft.

Occupied: Yes

Materials: Stucco, Masonary, and Wood Shingles

Prevalent Colors: White and Brown

Maintenance: Poor

Use: Liquor Store

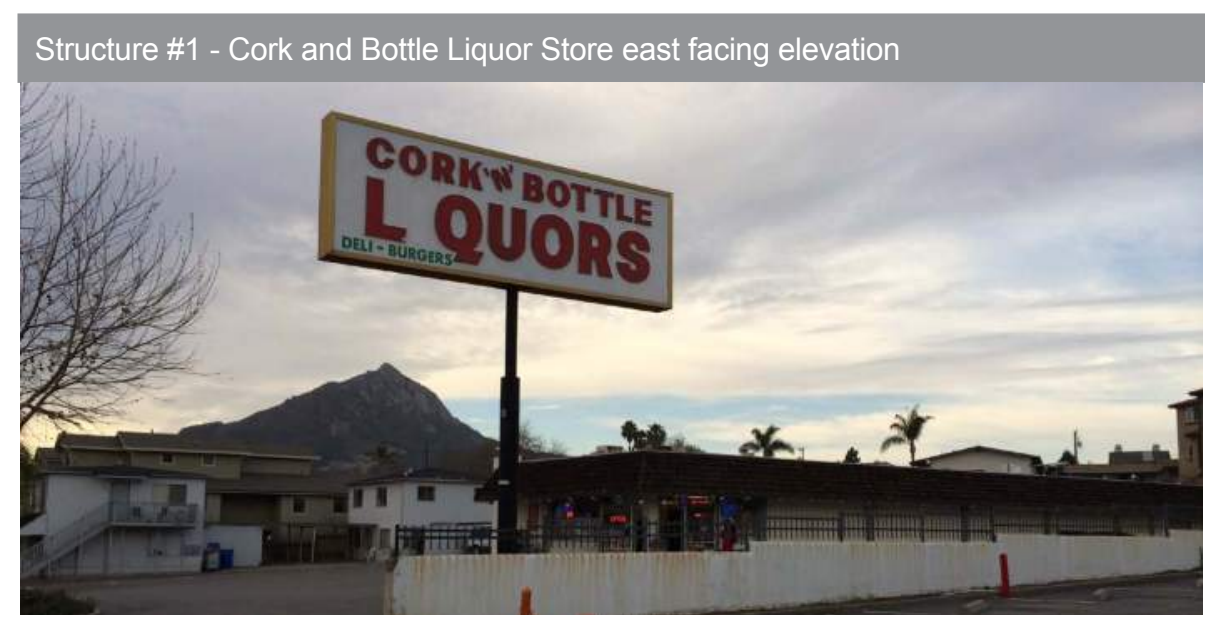

Structure \#1 - Cork and Bottle Liquor Store south facing elevation

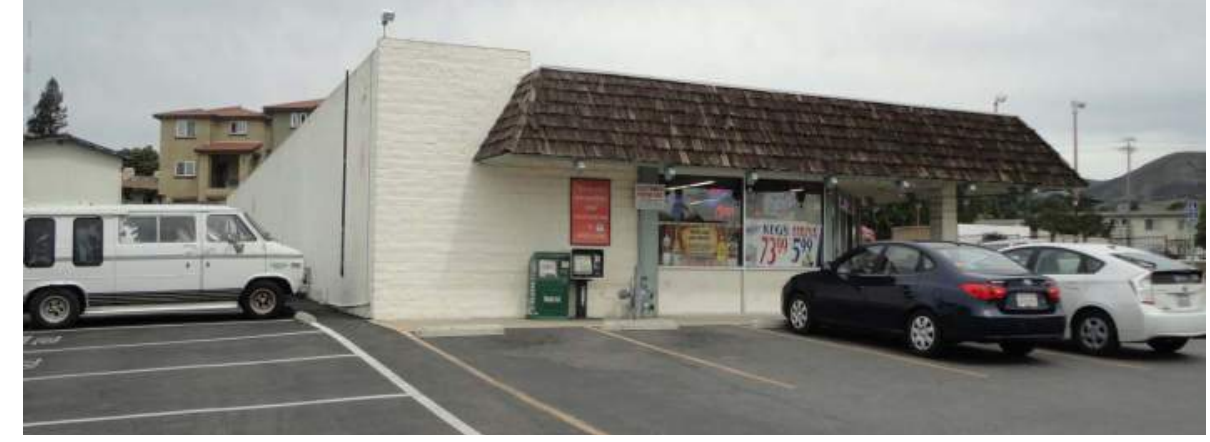

Structure 2 is a currently vacant building that used to house a fast food restaurant with a drive thru. The structure looks to have been built within the last 30 years and lacks any distinctive architectural style. The structure would not be worth saving during redevelopment of the Site. General Characteristics of the structure are as follows:

Redevelop: Yes

SQ Footage: 4,646 sq. ft.

Occupied: No

Materials: Stucco, Masonary, and Wood Shingles

Prevalent Colors: White, Red, and Brown

Maintenance: Poor

Use: Fast Food Restaurant

Structure \#2 - Vacant fast food restaurant east facing elevation

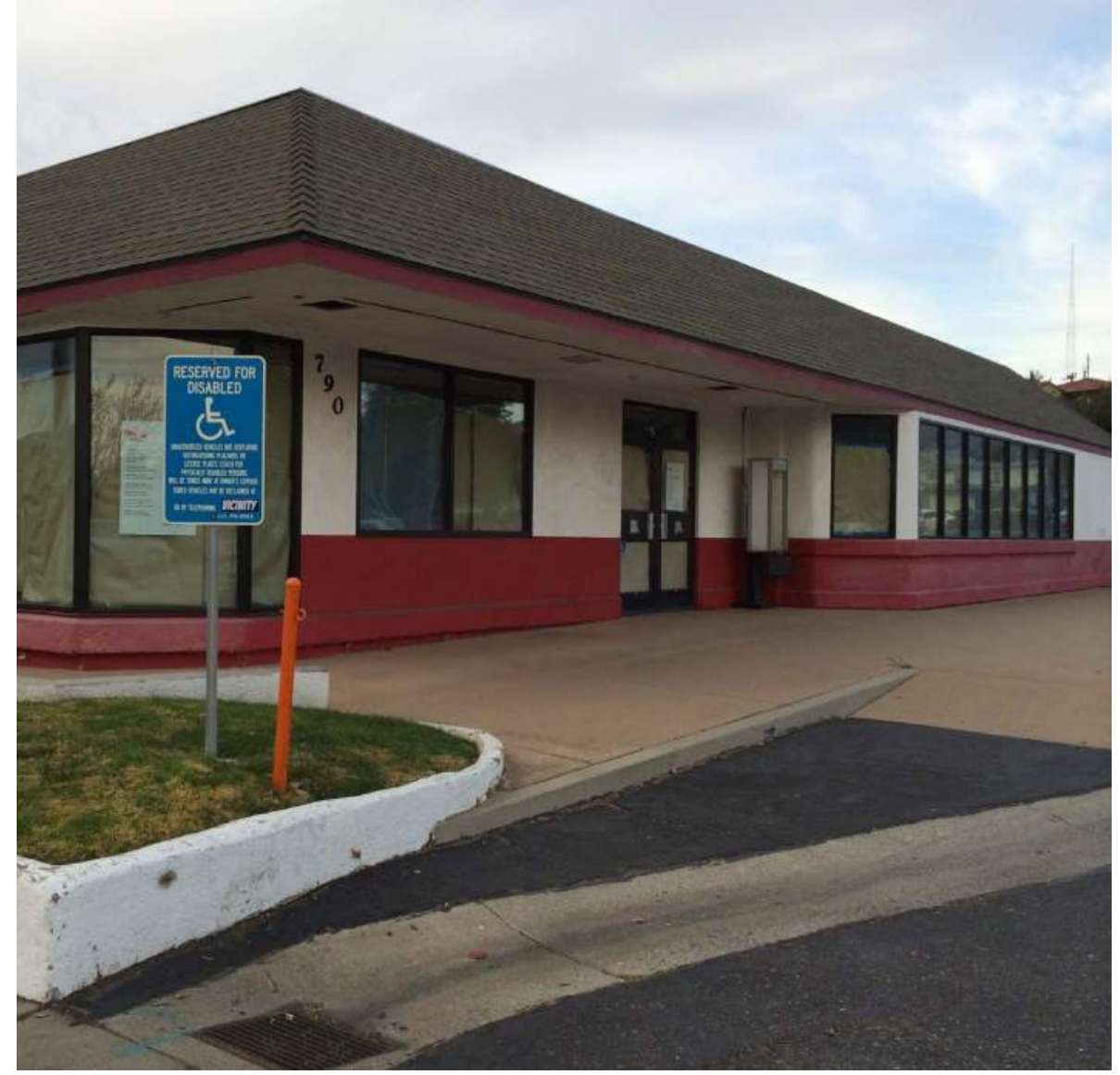


Structure 3 houses the Black Forest Cafe, a popular coffee shop. The architecture is contemporary, in good condition, and may be worth saving during redevelopment of the Site. General Characteristics of the structure are as follows:

Redevelop: Possible

SQ Footage: 1,241 sq. ft.

Occupied: Yes

Materials: Stucco and Corrugated Steel

Prevalent Colors: White, Red, and Black

Maintenance: Good

Use: Coffee Shop

Structure \#3 - Black Forest Cafe south and east facing elevations

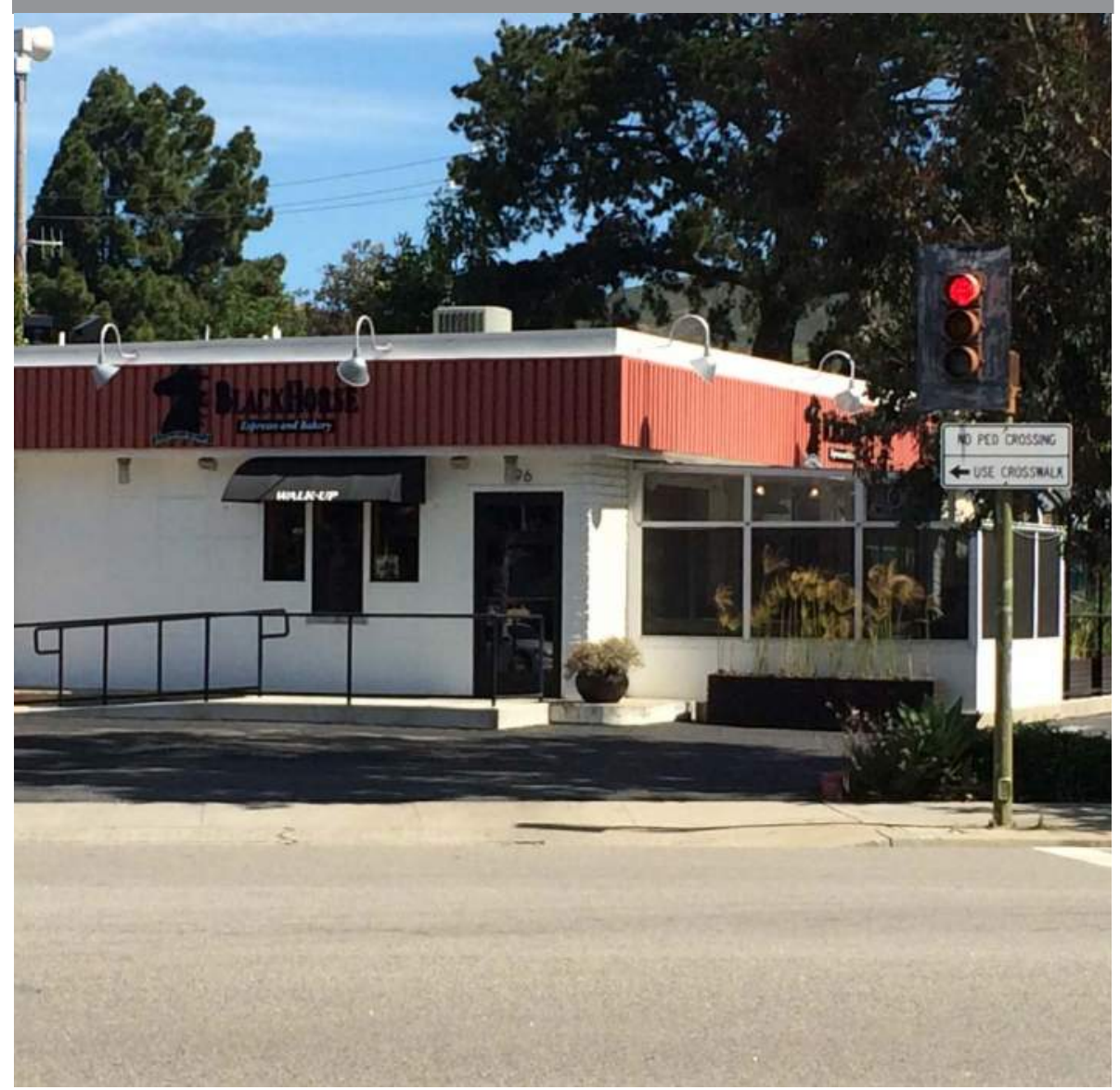

Structure 4 is the City of San Luis Obispo Fire Station \#2. The building is in fair condition and remains in active use. However, the Fire Departmen has expressed a desire to relocate to a new station as the current station does not have adequate room for maneuvering the fire engines. As such, the structure would not be worth saving during redevelopment of the Site. General Characteristics of the structure are as follows:

Redevelop: Yes

SQ Footage: 3,456 sq. ft.

Occupied: Yes

Materials: Stucco and Masonry

Prevalent Colors: White and Blue

Maintenance: Fair

Use: Fire Station

Structure \#4 - City of San Luis Obispo Fire Station \#2 west facing elevation

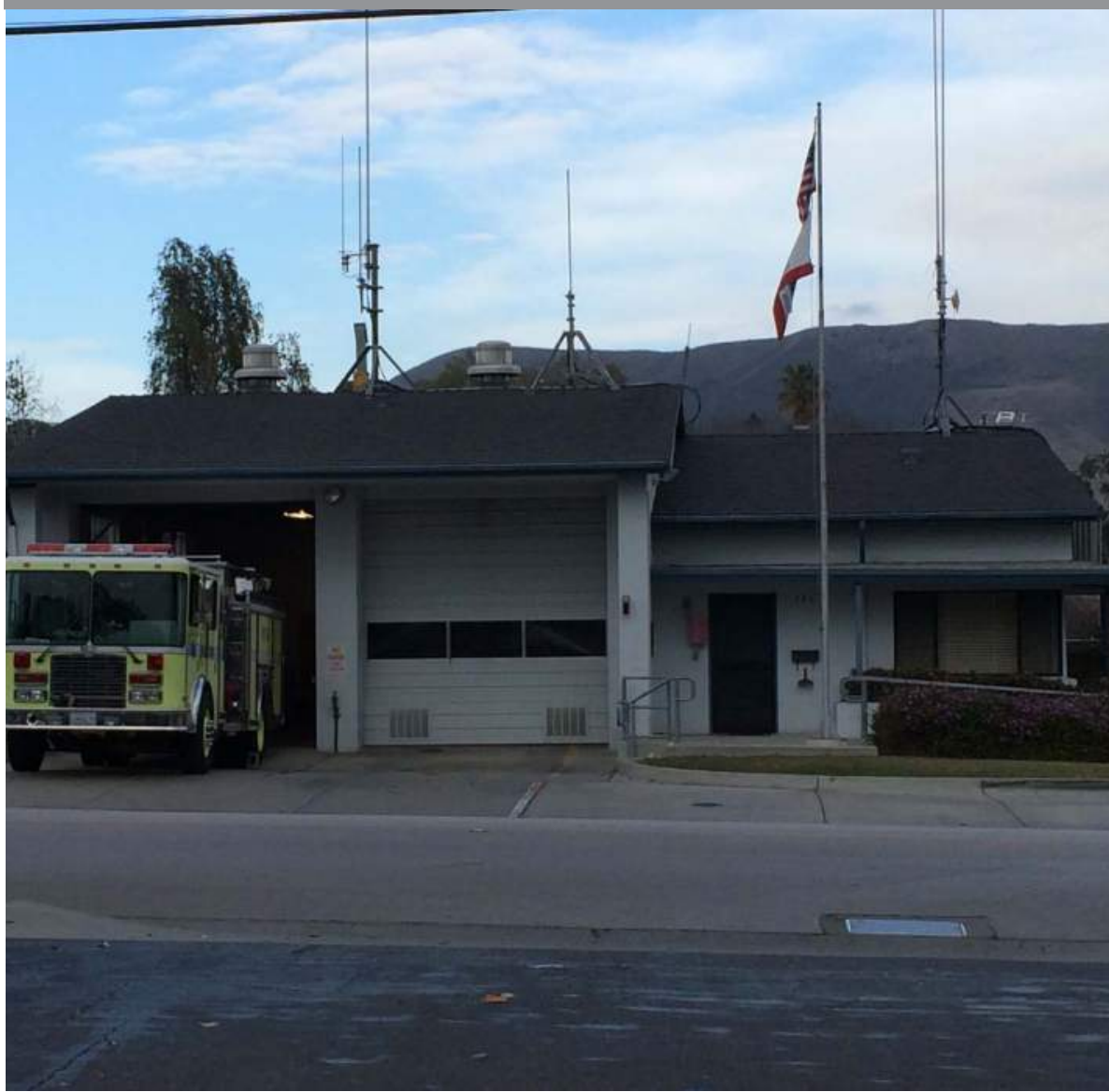


Structure 5 is half occupied by Golden 1 Bank and half vacant. The structure looks like it was build during the 1960's or 1970's and has the strip center architecture that was typical of that time. The structure would not be worth saving during redevelopment of the Site. General Characteristics of the structure are as follows:

Redevelop: Yes

SQ Footage: 8,741 sq. ft.

Occupied: Half Occupied, Half Vacant

Materials: Brick, Cast Concrete, and Steel Siding

Prevalent Colors: Brown

Maintenance: Poor

Use: Bank and Vacant

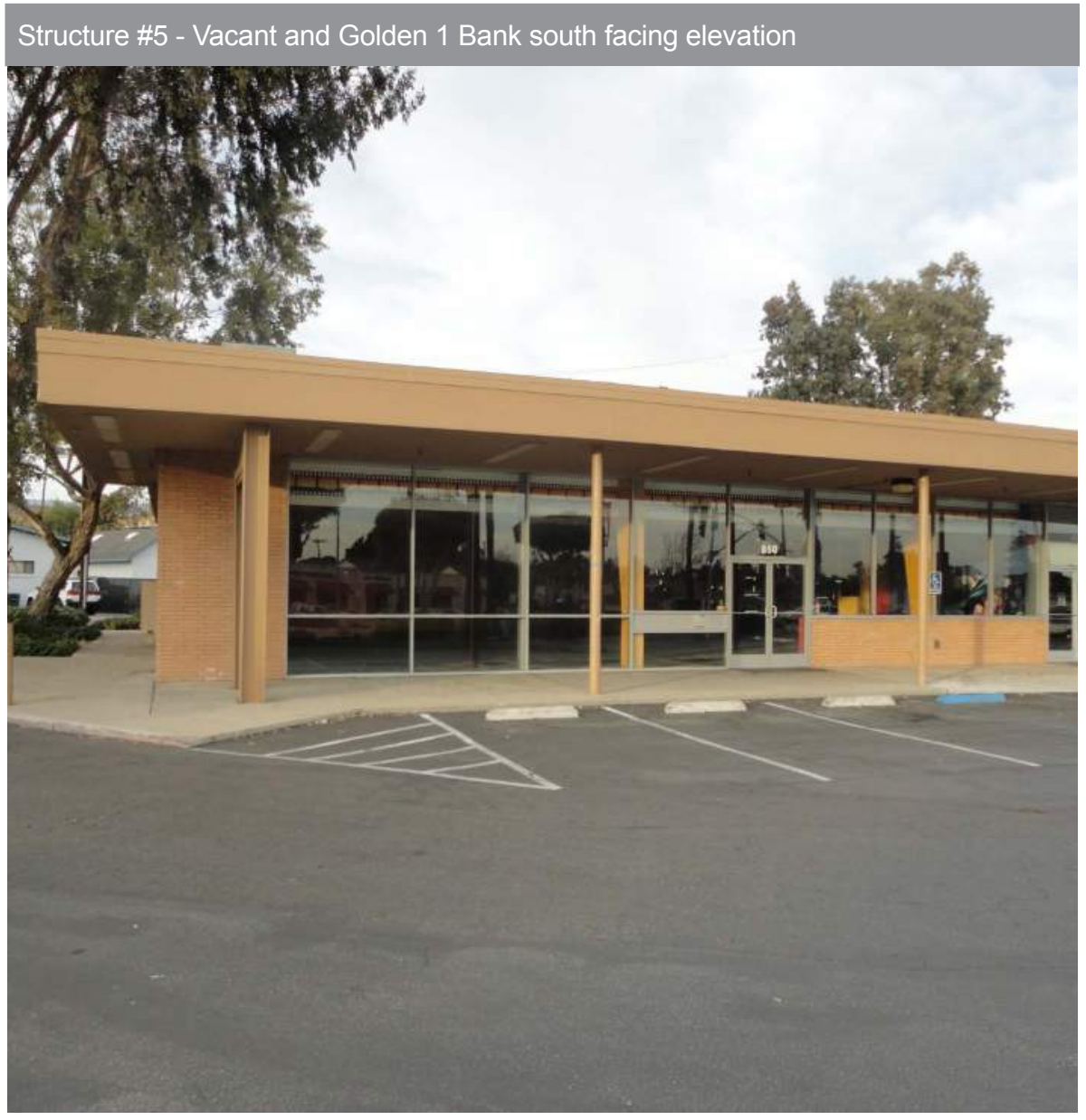

Structure 6 is the largest structure on the Site and houses Club 24 fitness center, University Barber Shop, Pita Pit, Dominoes Pizza, Traditional Tattoo Parlor, and many vacant units. The structure looks like it was build during the 1960's or 1970's and has the strip center architecture that was typical of that time. The structure would not be worth saving during redevelopment of the Site. General Characteristics of the structure are as follows:

\section{Redevelop: Yes}

SQ Footage: 43,322 sq. ft.

Occupied: Half Occupied, Half Vacant

Materials: Brick, Cast Concrete, and Steel Siding

Prevalent Colors: Brown

Maintenance: Poor

Use: Multiple Uses and Vacant

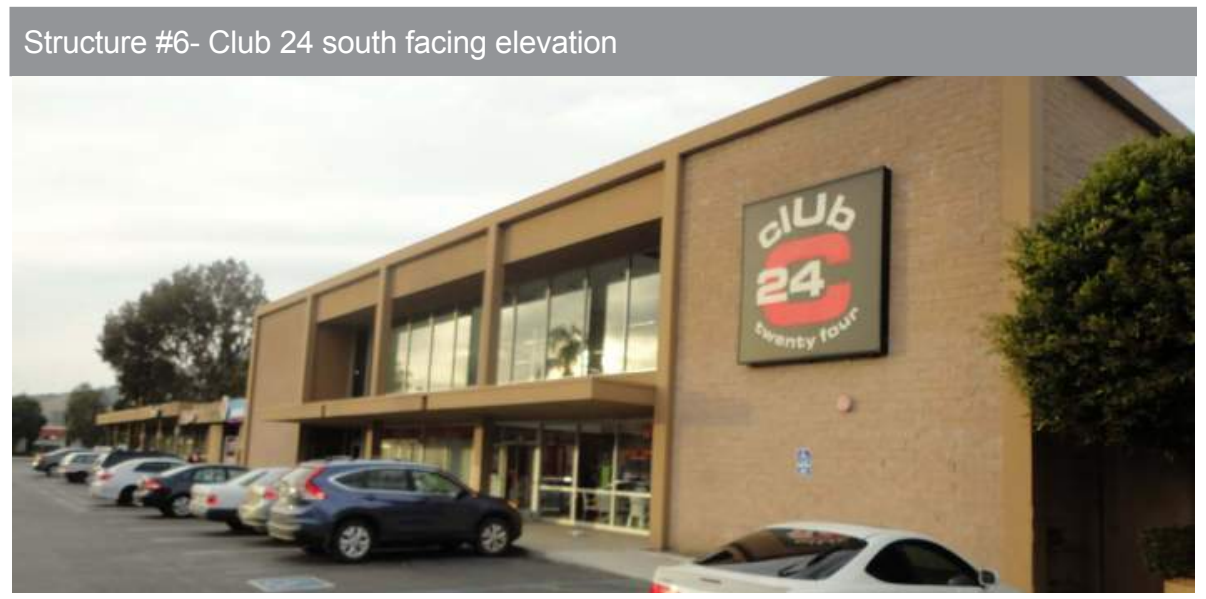

Structure \#5 - Vacant grocery store east facing elevation

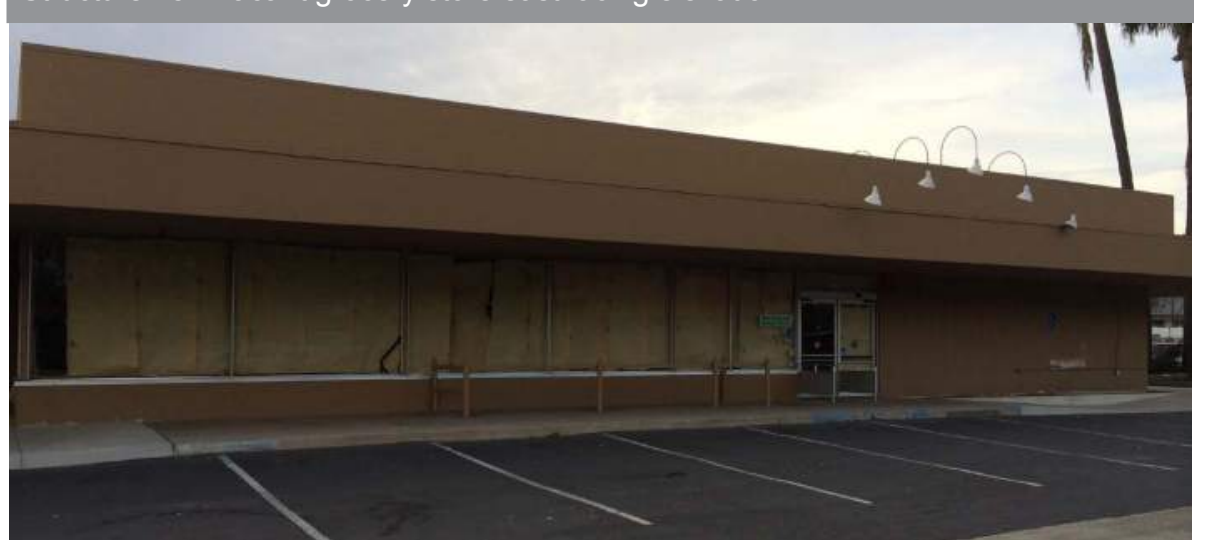


Structure 7 houses a Carl's Jr. fast food restaurant franchise. The structure looks to have been built within the last 30 years and lacks any distinctive architectural style. The structure would not be worth saving during redevelopment of the Site. General Characteristics of the structure are as follows:

Redevelop: Yes

SQ Footage: 5,141 sq. ft.

Occupied: Yes

Materials: Stucco, Masonary, and Wood Shingles

Prevalent Colors: Red and Brown

Maintenance: Fair

Use: Fast Food Restaurant

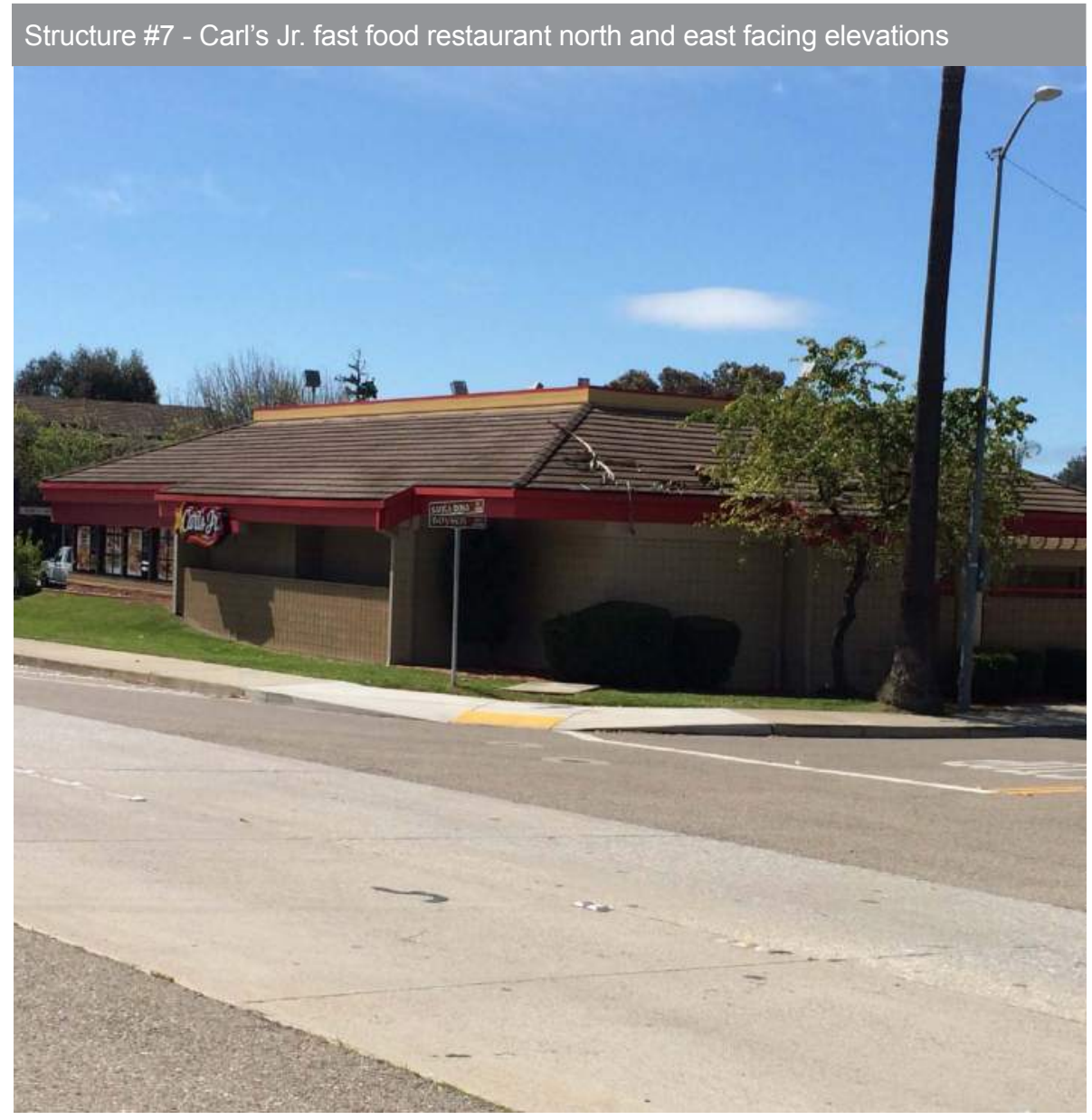

Structure 8 is medical offices for the Cuesta Medical Group and is likely the newest structure on the Site. The architecture is contemporary, in good condition, and may be worth saving during redevelopment of the Site. General Characteristics of the structure are as follows:

Redevelop: Possible

SQ Footage: 2,131 sq. ft.

Occupied: Yes

Materials: Masonary

Prevalent Colors: White, Red, and Brown

Maintenance: Good

Use: Medical Offices

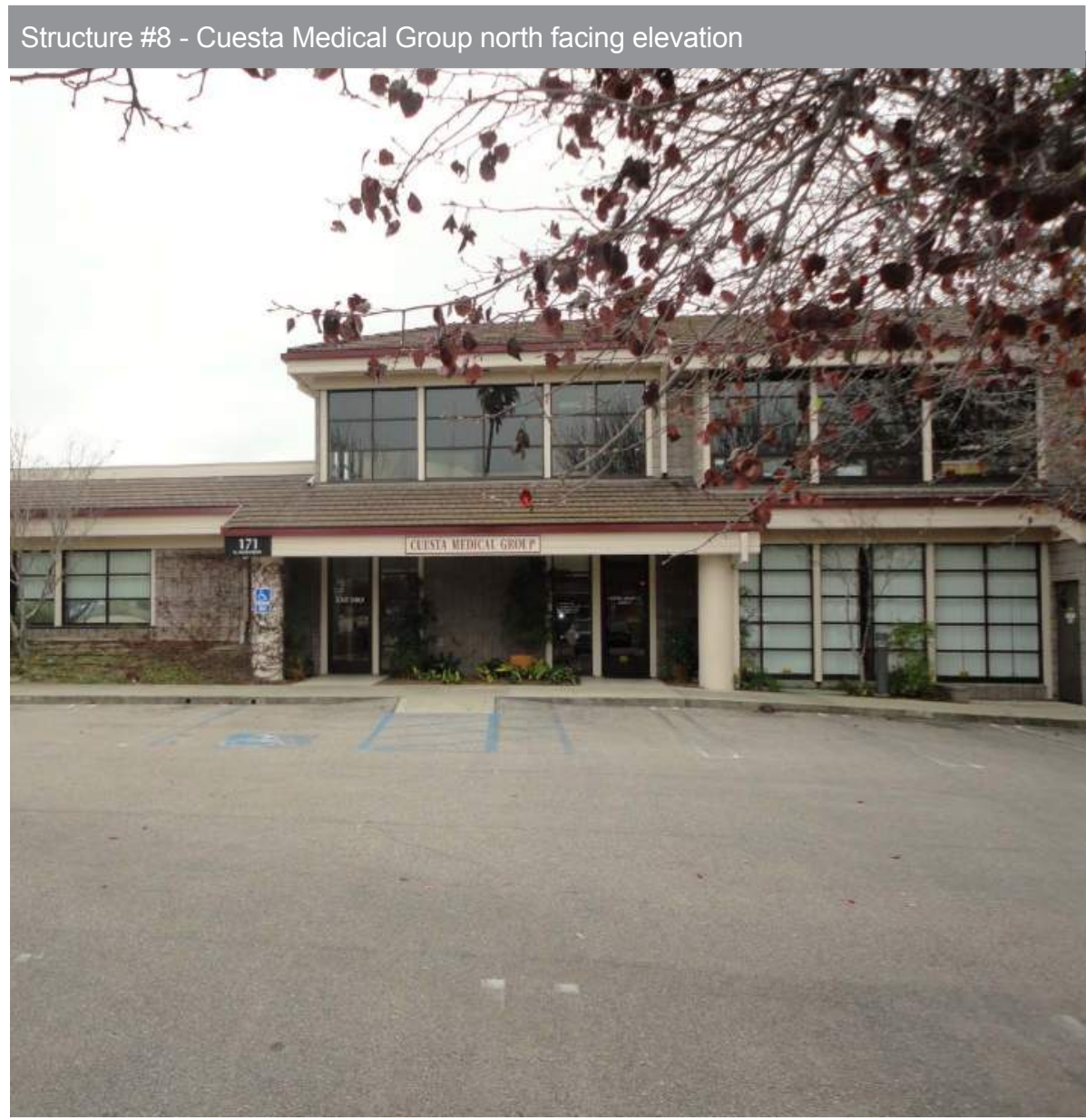


Structure 9 is the second largest structure, and the one in the most disrepair on the Site. It looks to have been build during the same period as Structures 5 and 6 and would not be worth saving during redevelopment of the Site. General Characteristics of the structure are as follows:

Redevelop: Yes

SQ Footage: 26,648 sq. ft.

Occupied: No

Materials: Stucco, Glass, Cast Concrete, and Steel Siding

Prevalent Colors: Brown

Maintenance: Poor

Use: Vacant

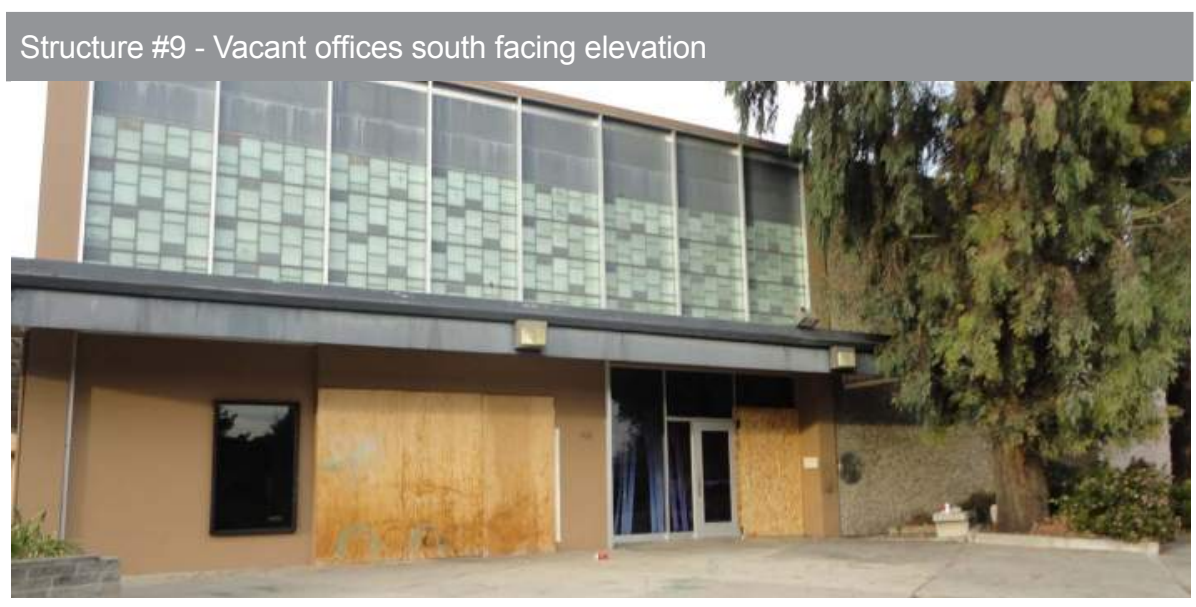

Structure \#9 - Vacant offices west facing elevation

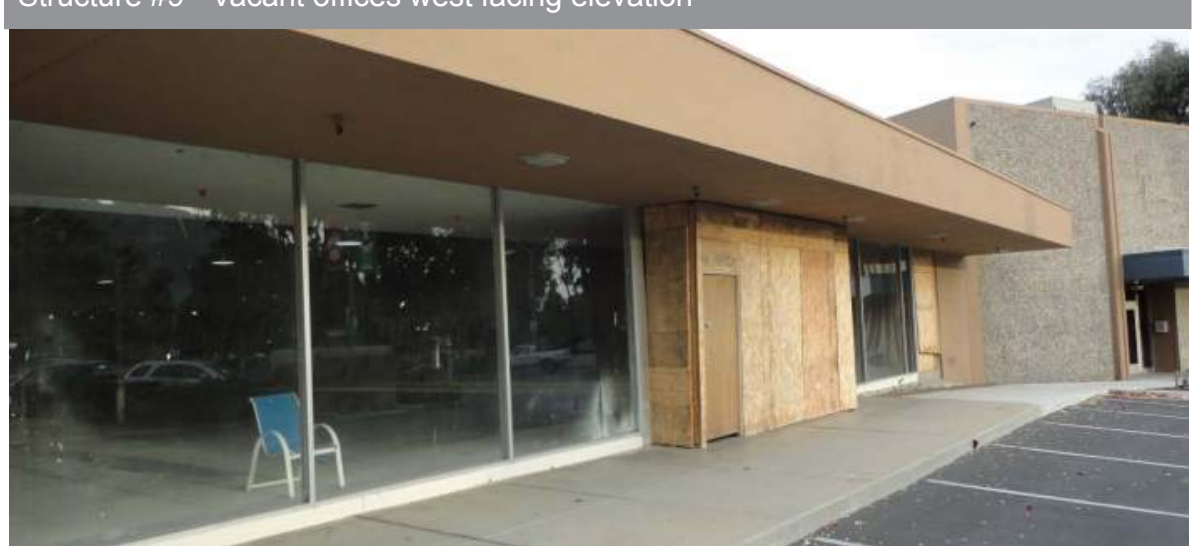

Structure 10 on the corner of Santa Rosa Street and Foothill Boulevard is in use as a Chevron Gas Station. The structure looks to have been built within the last 20 years and is in good condition but lacks any distinctive architectural style. The structure fails to take advantage of the unique site and would not be worth saving during redevelopment of the Site. General Characteristics of the structure are as follows:

Redevelop: Yes

SQ Footage: 2,363 sq. ft.

Occupied: Yes

Materials: Stucco

Prevalent Brown

Maintenance: Good

Use: Gas Station

Structure \#10 - Chevron Gas Station east facing elevation

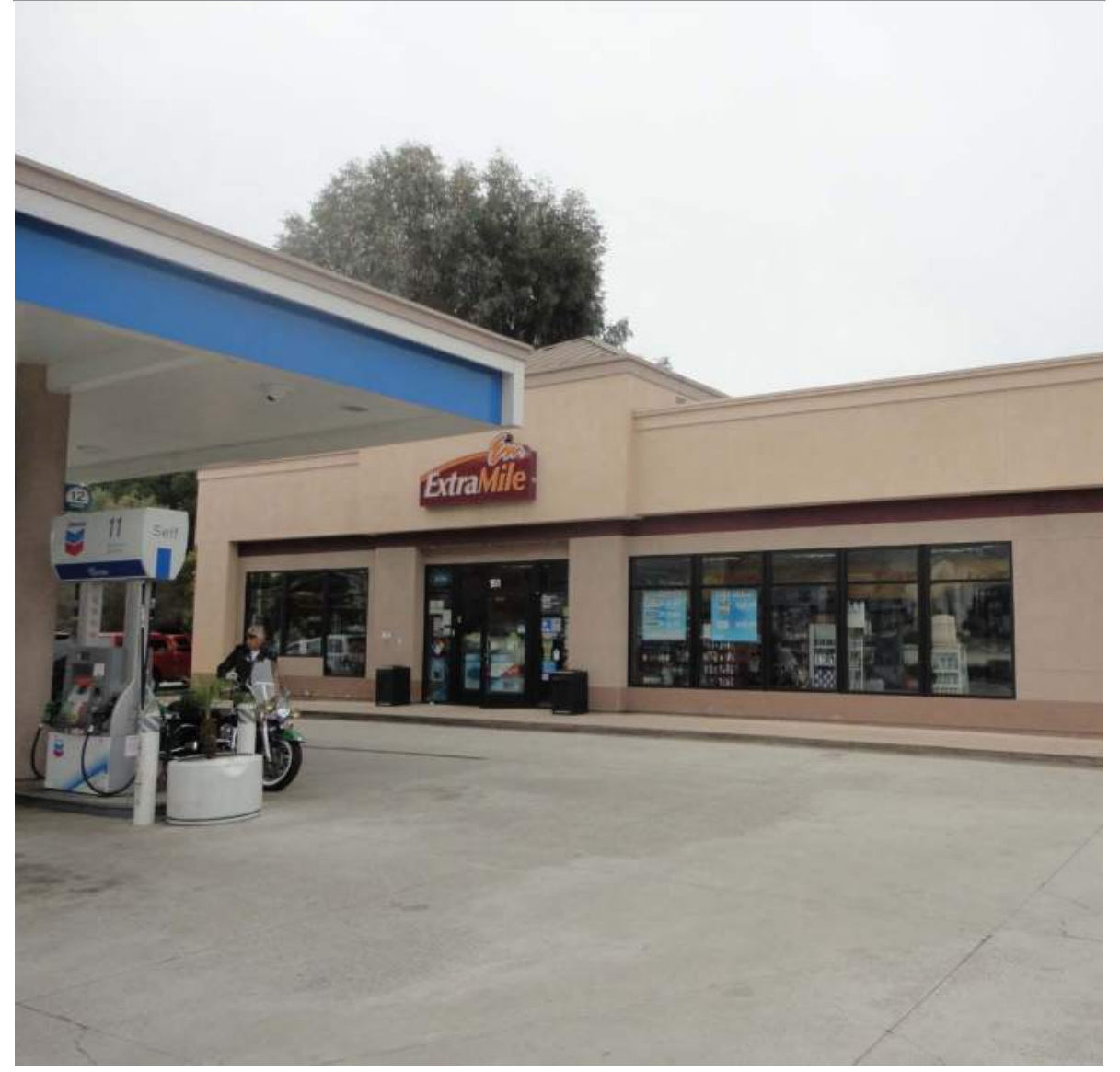




\subsection{LAND OWNERSHIP}

The Site's 8.2 acres is currently owned by five different parcel owners: NKT Commercial, BJ Steiner, City of San Luis Obispo, Polin Family Trust, and Estes Edna. Figure 3.7 shows parcels by ownership, while Table 3.2 shows total ownership acreages. For the purposes of ease, comprehensive redevelopment of the University Square Site should be undertaken by one owner/developer. The feasibility of this option is further discussed in Section 6.0: Financing and Implementation.

\begin{tabular}{|l|r|}
\hline Owner & Acres \\
\hline Estes Edna & 0.6 \\
\hline Polin Family Trust & 1 \\
\hline NKT Commercial & 5.6 \\
\hline BJ Steiner & 0.8 \\
\hline City of SLO & 0.4 \\
\hline
\end{tabular}

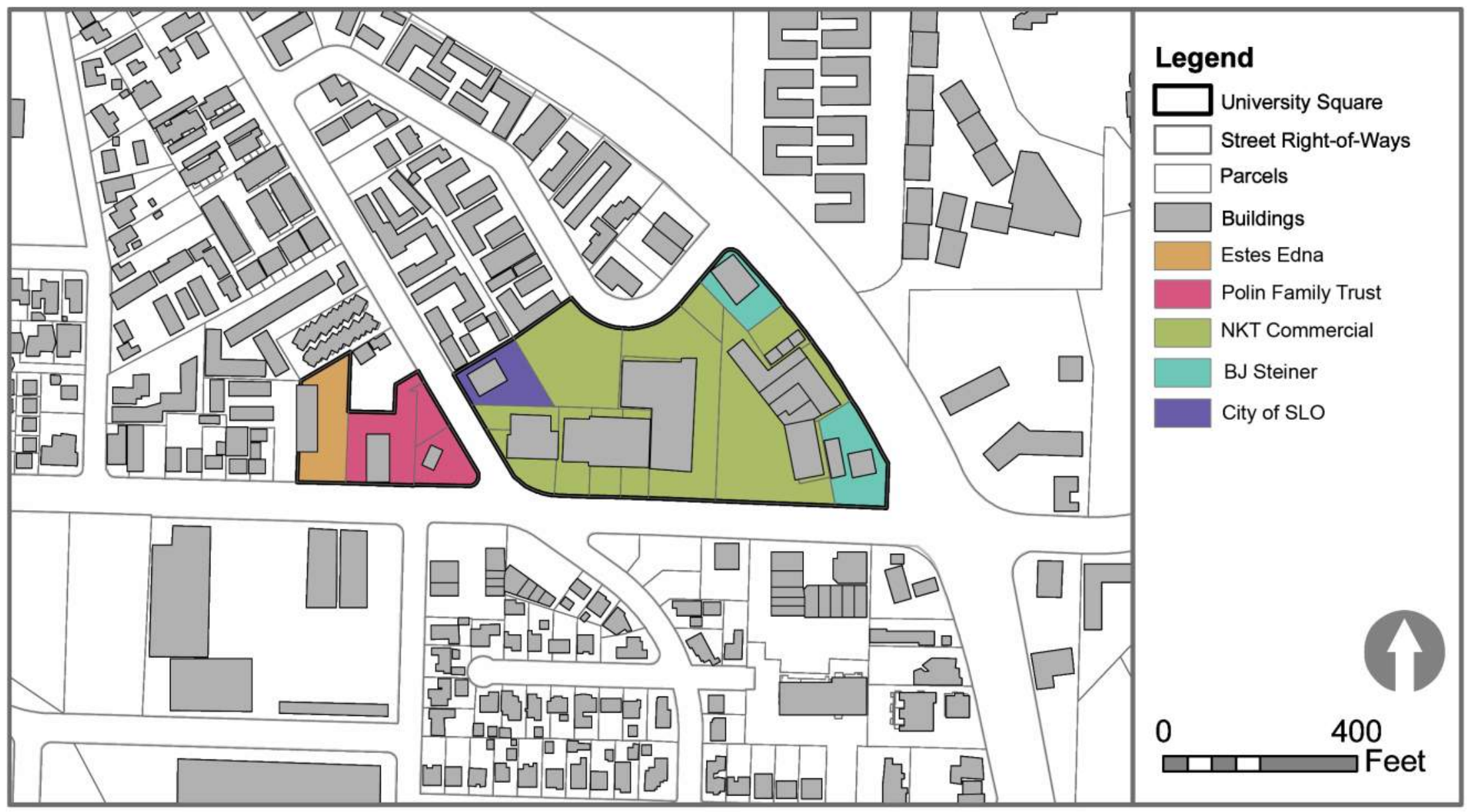




\subsection{ZONING AND LAND USE REGULATIONS}

The SLO General Plan and the San Luis Obispo Zoning Regulations govern land use controls for the University Square Site. Prior to any redevelopment of the Site, an analysis of the existing zoning and land use regulations can provide insight into the local regulatory environment.

\subsubsection{Zoning}

Figure 3.8 shows the Site's zoning designations: Commercial Retail with Special
Overlay (C-R-S), Neighborhood Commercial (C-N), and Public Facilities (PF). The Commercial Retail Zone is intended to provide for a wide range of retail sales, businesses, and personal and professional services on a regional scale. The special overlay allows additional land uses with a special use permit. The Neighborhood Commercial Zone focuses on providing retail sales and personal services primarily for the convenience of surrounding residential areas, in small-scale, pedestrian-oriented developments. The Public Facilities Zone is intended to provide for public land uses (i.e. schools, police and fire facilities, utilities, etc.) that are likely to be located on public property.

All current land uses on the University Square do, for the most part, match the purpose and intent of the City's Zoning Regulations. The parcel zoned

FIGURE 3.8 - Current Zoning Map, Data Source: City of San Luis Obispo

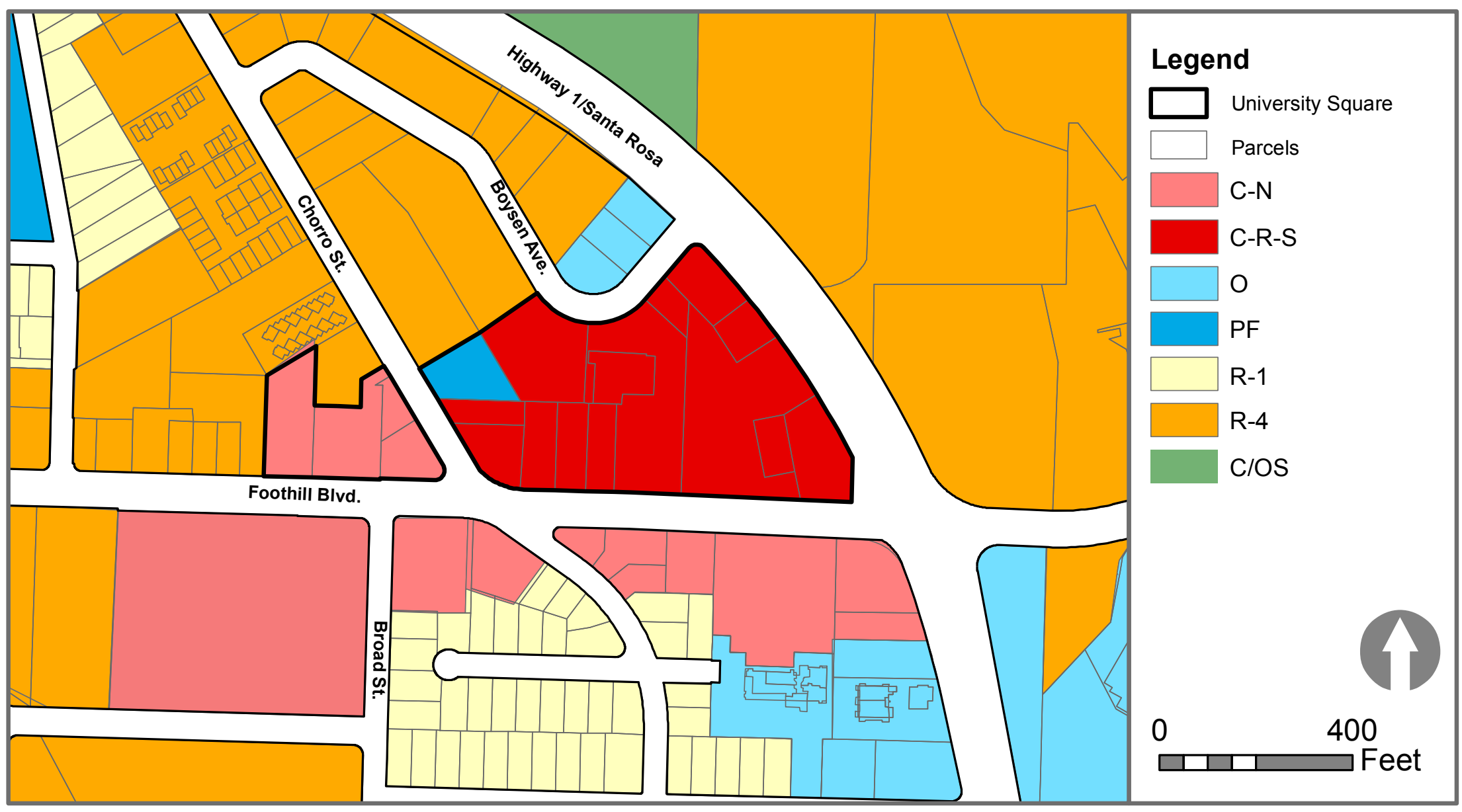


Public Facilities contains a City fire station, and one of the parcels zoned Neighborhood Commercial contains a small neighborhood serving market and deli. However, the abundance of underutilized parcels and low scale commercial activity in the Commercial Retail with Special Overlay zone fails to match the regional serving purpose described in the Zoning Regulations. The special overlay zoning allows for special provisions in addition to those underlying the Commercial Retail Zone. Under a Conditional Use Permit approved by the planning commission, the Special Overlay zone can allow for a greater range of land uses than is currently seen on the Site, including residential uses. As is, the zoning accommodates 83,000 sq. $\mathrm{ft}$. or retail uses and a maximum of 176 apartment units.

\subsubsection{Adjacent Land Uses and Zoning}

The areas directly adjacent to the Site include two zoning designations from the San Luis Obispo Zoning Regulations: High Density Residential (R-4), and Office (O). The High Density Residential Zone is intended to provide various types of group housing and concentrations of housing close to concentrations of employment and college enrollment. The Office Zone is intended to provide for offices and related functions close to medical facilities and the downtown, convenient to public transportation and related government and business services.

\subsubsection{Land Use Regulations}

Land use regulation standards that accompany the zoning for the University Square Site are contained in Table 3.3. Though the current land use regulations and zoning may not adequately accommodate the mixed-use development typology proposed in this document, the proposal for the Site from the Land Use and Circulation Element (LUCE) update of the City's General Plan should provide the necessary regulatory context under which it can occur.

\subsubsection{Land Use and Circulation Update}

The most recent City Council Recommended Draft of the Land Use Element from January 28, 2014 defines the "Foothill Boulevard/Santa Rosa Area" as a "Special Planning Area" in Section 8.3.3. This section states that: "The City shall work with property owners/developers to redevelop the area as mixed-use to include a mix of uses as described under the Neighborhood Commercial, Community Commercial and Medium High to High Density Residential designations," (San Luis Obispo City Council Recommended Draft Land Use and Circulation Element update, 1/28/14,pg. 1-137). Once the new elements are adopted It is expected that the zoning for the property will change to mixuse and new more favorable site specific land use regulations will apply.

TABLE 3.3 - Land Use Regulations, Data Source: City of San Luis Obispo

\begin{tabular}{|l|c|c|c|}
\hline \multicolumn{1}{|c|}{ Standards } & $\begin{array}{c}\text { Retail Commercial Special } \\
\text { Overlay (C-R-S) }\end{array}$ & Neighborhood Commercial (C-N) & Public Facilities (PF) \\
\hline Maximum Density (Units/Net Acre) & 36 units/acre & 12 units/ acre & N/A provided in zone of adjacent lot \\
\hline Minimum Street Yard (Feet) & As provided in zone of adjacent lot & 5 feet & As provided in zone of adjacent lot \\
\hline Minimum Other Yard (Feet) & As provided in zone of adjacent lot & 35 feet & 35 feet \\
\hline Maxium Building Height (Feet) & 45 feet & 6,000 sq. ft & 6,000 sq. ft \\
\hline Minium Lot Area (Square Feet) & 9,000 sq. ft & 60 feet & 60 feet \\
\hline Minimum Lot Width (Feet) & 60 feet & 90 feet & 90 feet \\
\hline Minimum Lot Depth (Feet) & 100 feet & $75 \%$ & $60 \%$ \\
\hline Maximum Lot Coverage (Percent) & $100 \%$ & 40 feet & 40 feet \\
\hline Minimum Street Frontage (Feet) & 40 feet & Based on type of use & Based on type of use \\
\hline Parking Requirement & Based on type of use & & A \\
\hline
\end{tabular}




\subsection{CIRCULATION}

This section discusses vehicular, pedestrian, and bicycle circulation affecting the Site. This includes an analysis of the local street classifications, parking, transit services, sidewalks, and bike facilities.

\subsubsection{Streets}

Streets accommodate all modes of travel. However, this section describes the vehicular aspect of surrounding streets. The site is bounded by Foothill Boulevard, Boysen Avenue, Highway 1/Santa Rosa Street, and bisected by Chorro Street. San Luis Obispo uses six levels of street classification that differentiate design, acceptable volumes, design standards, and various functions of the roads. The streets that abut the site fall under four of these classifications: regional highways, arterials, residential collectors, and local streets (Figure 3.9 diagrams the street classifications.)

Highway $1 /$ Santa Rosa is a regional highway that connects the 101 freeway to San Luis Obispo coastal communities and Big Sur. The segment that abuts the Site has maximum speeds of $45 \mathrm{mph}$, two travel lanes in each direction, two left turn lanes and one right hand turn lane on the southbound side, one left turn lane and a merge lane on the northbound side. The arterial street classification, which includes Foothill Boulevard, connects major developed parcels and regional highways. Arterials are typically designed to accommodate $25 \mathrm{mph}$ to $45 \mathrm{mph}$ traffic speeds, and have two to four lanes of travel, turning

FIGURE 3.9 - Street Classification Map, Data Source: City of San Luis Obispo

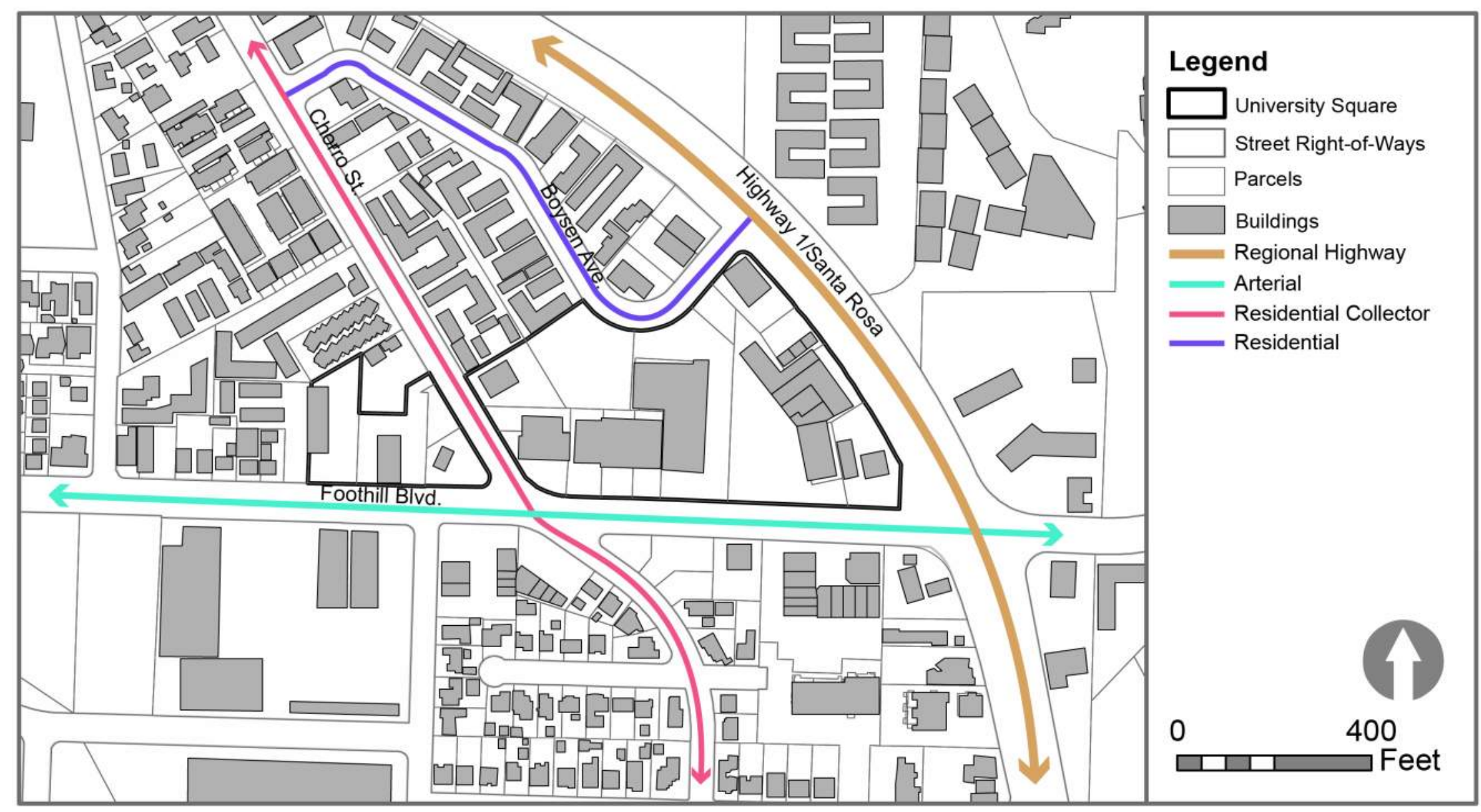


lanes, and may have medians installed to assist in the control of turning movements. Intersections with lower classified streets may have signalization or stop signs. Residential collector streets, including Chorro Street, collect traffic from residential areas and channel it to the arterials. Travel speeds are generally $25 \mathrm{mph}$, with two lanes of travel, and stop signs and/or signalization at intersections. Local streets directly serve the residential developments that front them and channel traffic to the residential collector streets. Local streets typically have two lanes of travel, on-street parking, sidewalks, curbs, and gutters. The street classifications have a major impact on the Site and contribute to ease or complexity of access. The high speeds of Highway 1/ Santa Rosa Street, and congestion of the intersection of Foothill and Santa Rosa create an unsafe environment for ingress and egress. Achieving safe site access may require realignment, and/or speed reduction strategies of the local street network. Street improvements are further discussed in Section 5.0: Project Development.

\subsubsection{Transit}

The Site is well served by local transit. Figure 3.10 shows local bus routes, including SLO Transit bus routes 1, 4, 5, and 6A that all stop at University Square. These routes, in aggregate, provide transit access to the rest of the City, including Downtown and Cal Poly. Additionally, San Luis Obispo County Regional Transit Authority (RTA) route 12 has a stop at Foothill and Santa Rosa, connecting the site by transit to the local beach communities of Morro Bay, Cayucos, and Cambria.

FIGURE 3.10 - Bus Routes Map, Data Source: City of San Luis Obispo and San Luis Obispo County Regional Transit Authority

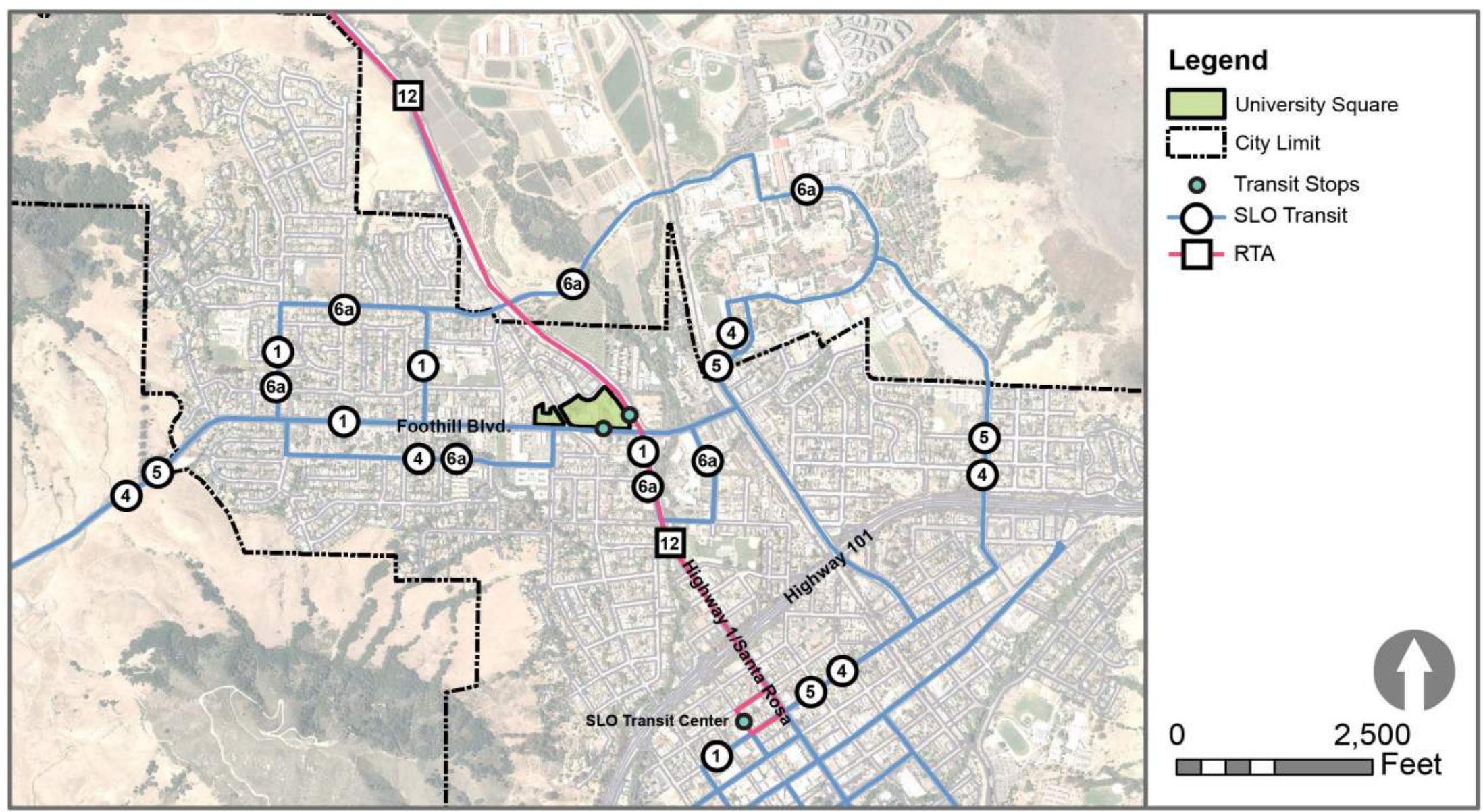


The University Square Site currently contains approximately 5.06 acres of parking see Figure 3.11). This is a vast amount of parking compared to the 8.4 total site acres. These large expanses of parking detract from the areas pedestrian orientation, streetscape, and are out of scale with the surrounding community.

The Site has fifteen (15) ingress and egress points. This relatively large number is due to poor site design and an abundance of auto-serving land uses. Better site design and new uses on the Site should prevent the need for so many automobile access points.
The sidewalks on the perimeter of the Site are all maintained by the City and are in good condition; however; internal pedestrian mobility is severely limited with no direct pedestrian travel routes. Many Cal Poly students cross Highway 1 adjacent to the Site via the crosswalk at Foothill Boulevard, or by jaywalking closer to Boysen Ave. This presents a major safety challenge for student pedestrian access to and from the Site. Bike routes are limited to Highway 1 and Foothill Boulevard, with dedicated lanes of travel in each direction. Both the pedestrian and bike routes receive high traffic from local commuters (particularly to and from Cal Poly.) However, the site remains relatively unfriendly to both modes.

\section{FIGURE 3.11 - Bike Routes and Parking Map}

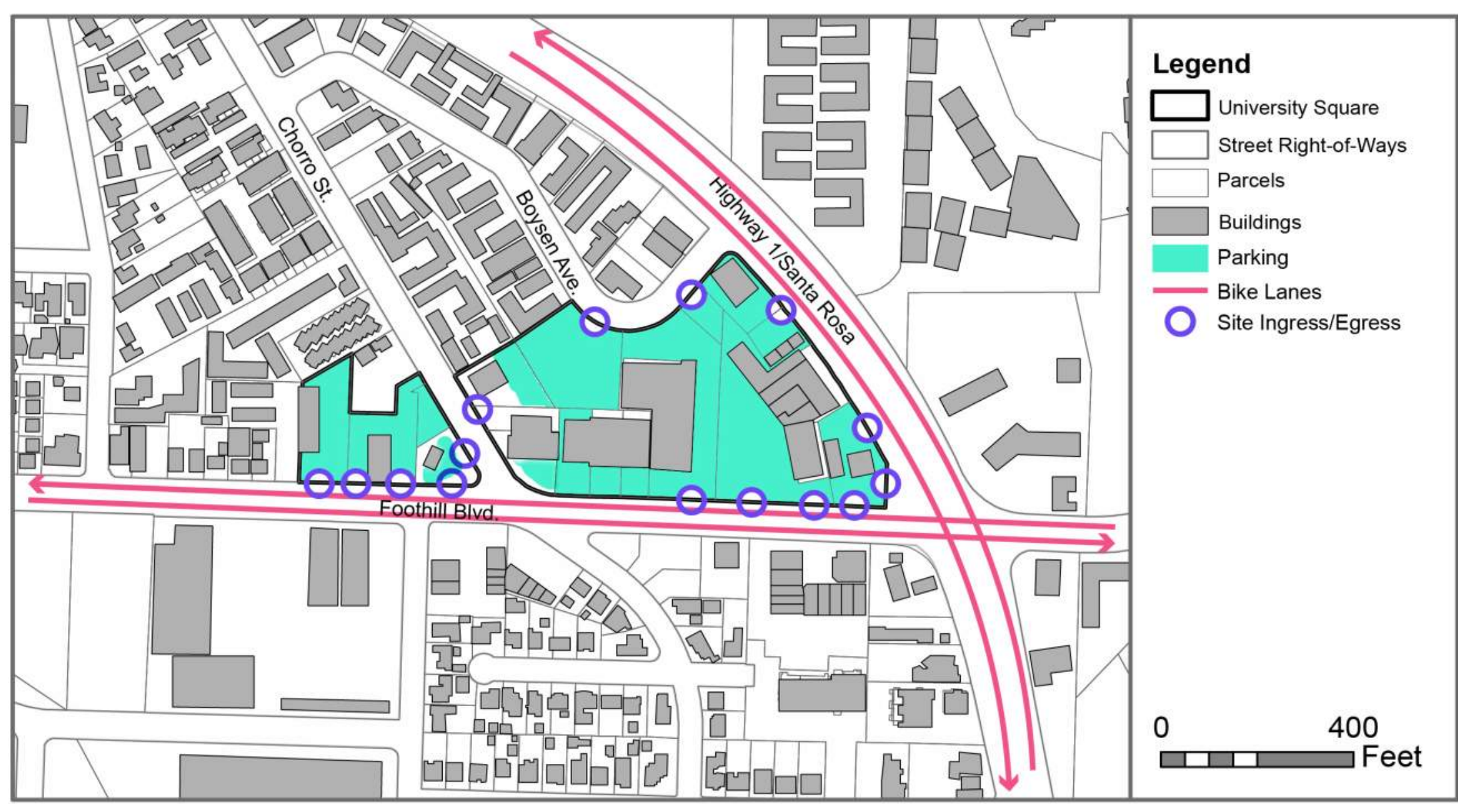




\subsection{UTILITIES}

The City of San Luis Obispo Utilities Department manages stormwater, wastewater, and water (potable). Figure 3.12 shows the locations of stormwater mains and manholes, wastewater mains and manholes, and water mains and water hydrants. The Site has each type of main running through it, as well as interior wastewater manholes and water hydrants. During the redevelopment of the Site care should be taken not to damage utilities. Additional engineering studies may also be needed to examine the feasibility of relocating the interior wastewater manhole.

Electricity and gas is provided and serviced by Pacific Gas and Electric (PG\&E). Most of the lines run underground; however; telephone and electric transmission lines run parallel along Chorro Street and Boysen Avenue, and bisect the Site between these two streets. During redevelopment of the Site these lines should be relocated underground.

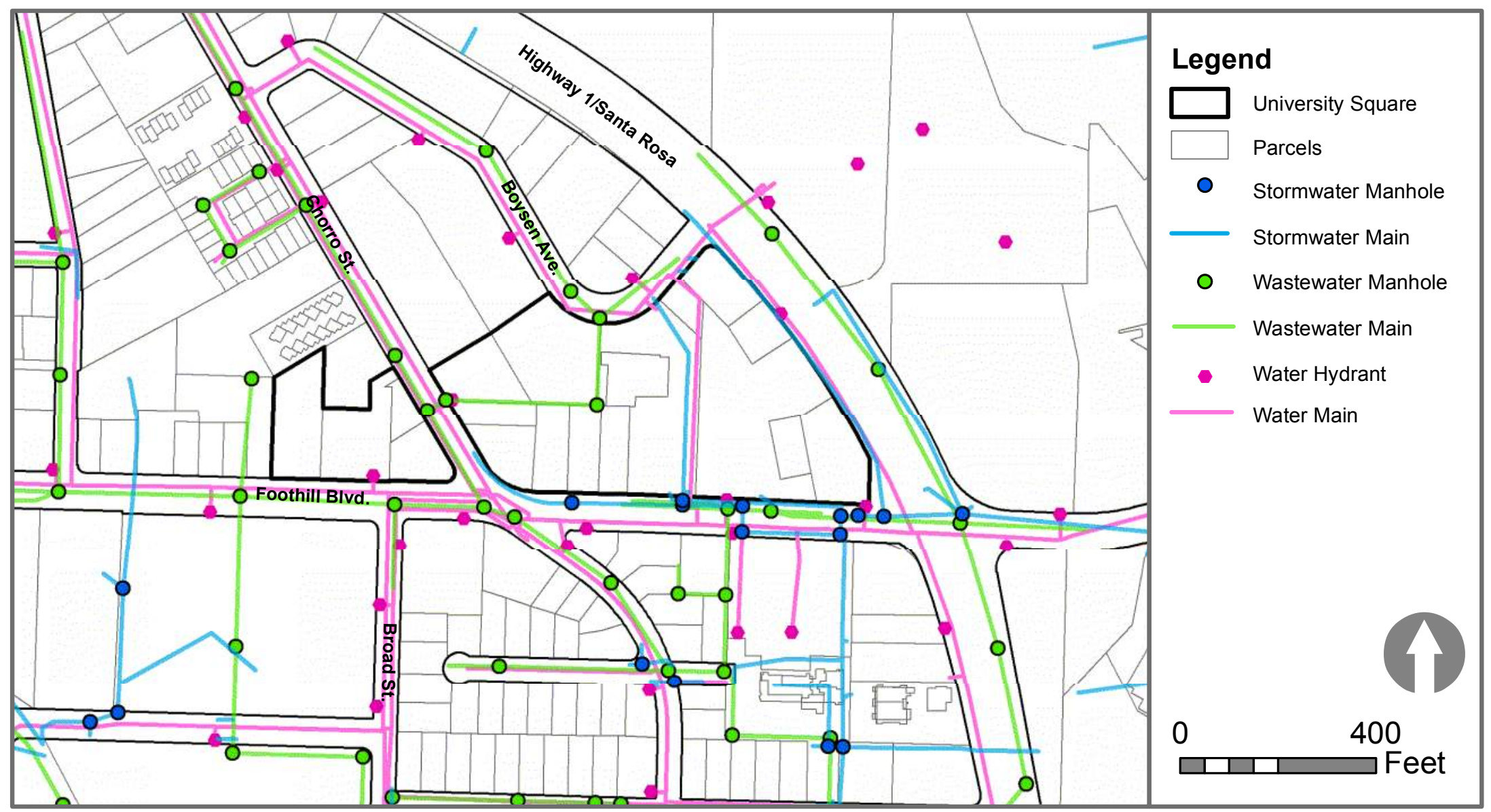




\subsection{TOPOGRAPHY AND SOILS}

Figure 3.13 shows the two-meter contour elevations and soil surrounding the Site. The Site is located in a valley and is relatively flat with a slight slope of 1 to 2 percent. To the north, Chorro Street raises to a peak of 300 feet at the intersection of Ferini Street. To the south, Chorro Street raises to a peak of 265 feet at the Murray intersection. The drainage issues that occur from the relationship of these peaks to the Site is discussed in Section 3.9.

The University Square Site contains two soil types: Salinas Silty Clay Loam, and Cropley Clay (City of San Luis Obispo, 2013). Salinas Silty Clay Loam is generally considered fertile, with good drainage characteristics, and suitable to support development. Likewise, Cropley Clay is a well-drained soil that formed in alluvium from mixed rock sources, and is less suitable for agriculture than Salinas Silty Clay Loam, but is appropriate for development. The University Square Site is mostly composed of Salinas Silty Clay Loam. Both the soil types and the topography make erosion unlikely, and serious site grading unnecessary.

FIGURE 3.13 - Contours and Soils Map, Data Source: City of San Luis Obispo

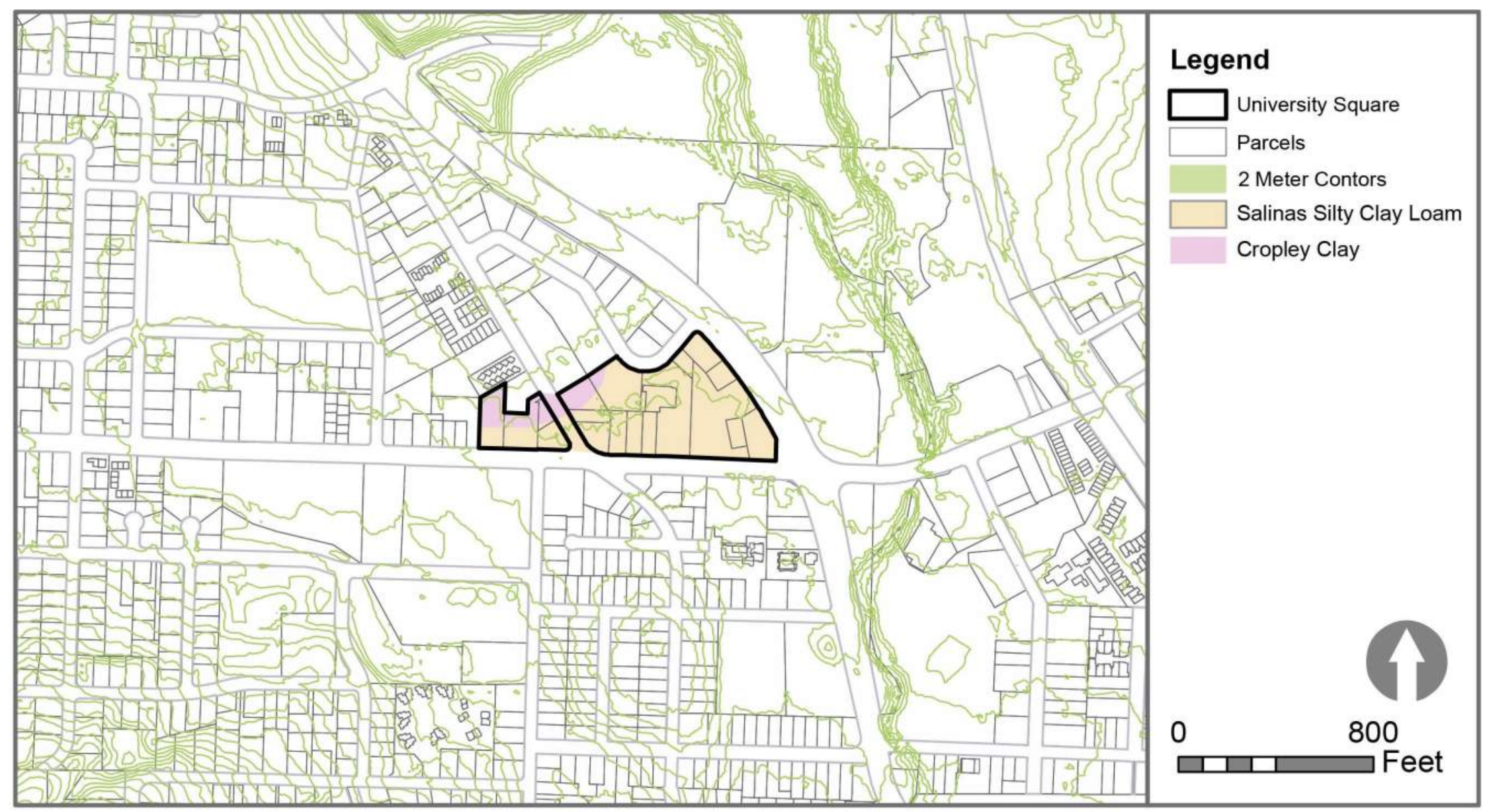




\subsection{HYDROLOGY AND DRAINAGE}

With its valley location the Site does face some hydrological and drainage issues. Figure 3.14 shows both the creeks and various flood zones that surround the site, demonstrating that there are potential drainage issues on the Southeast corner of the Site. Development will have to take this into account and should include systems for managing stormwater, and slightly higher baseline elevations on structures.

FIGURE 3.14 - Creeks and Flood Zones Map, Source: City of San Luis Obispo

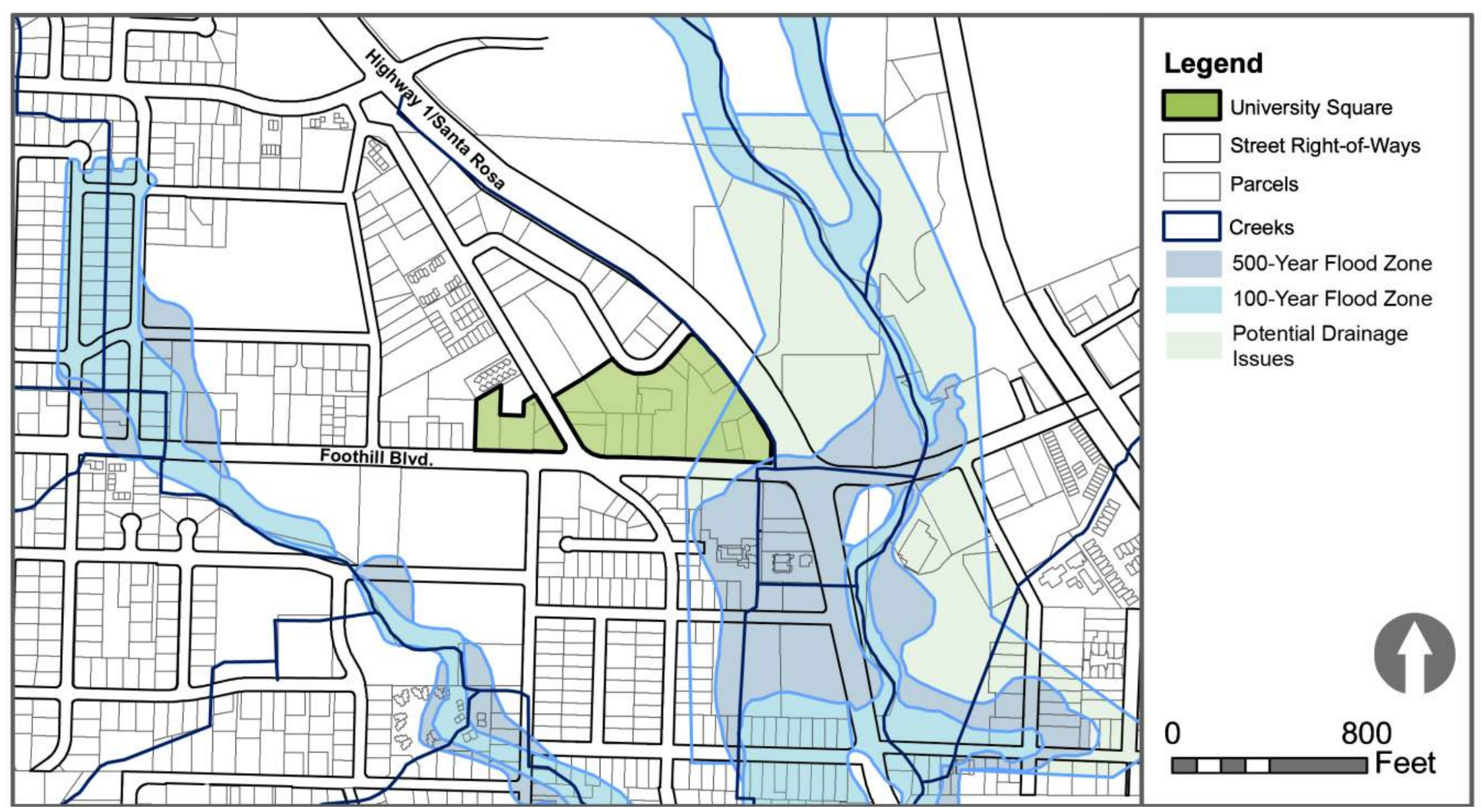




\subsection{VIEWS}

The Site is graced with prime views of the local hills including Bishops Peak and Cerro San Luis. However, most of the current structures are oriented away from these prime views and do not take advantage of the location. Future development should incorporate these views and structures and plazas should be oriented towards this excellent asset. Interior views of the Site are glimpsed when driving south and north on Highway 1/Santa Rosa, looking north from the intersection of Foothill Boulevard and Chorro Street, and on Foothill Boulevard facing east. Figure 3.15 diagrams some of the key view to and from the Site.

\section{FIGURE 3.15- Views In and Out Map}

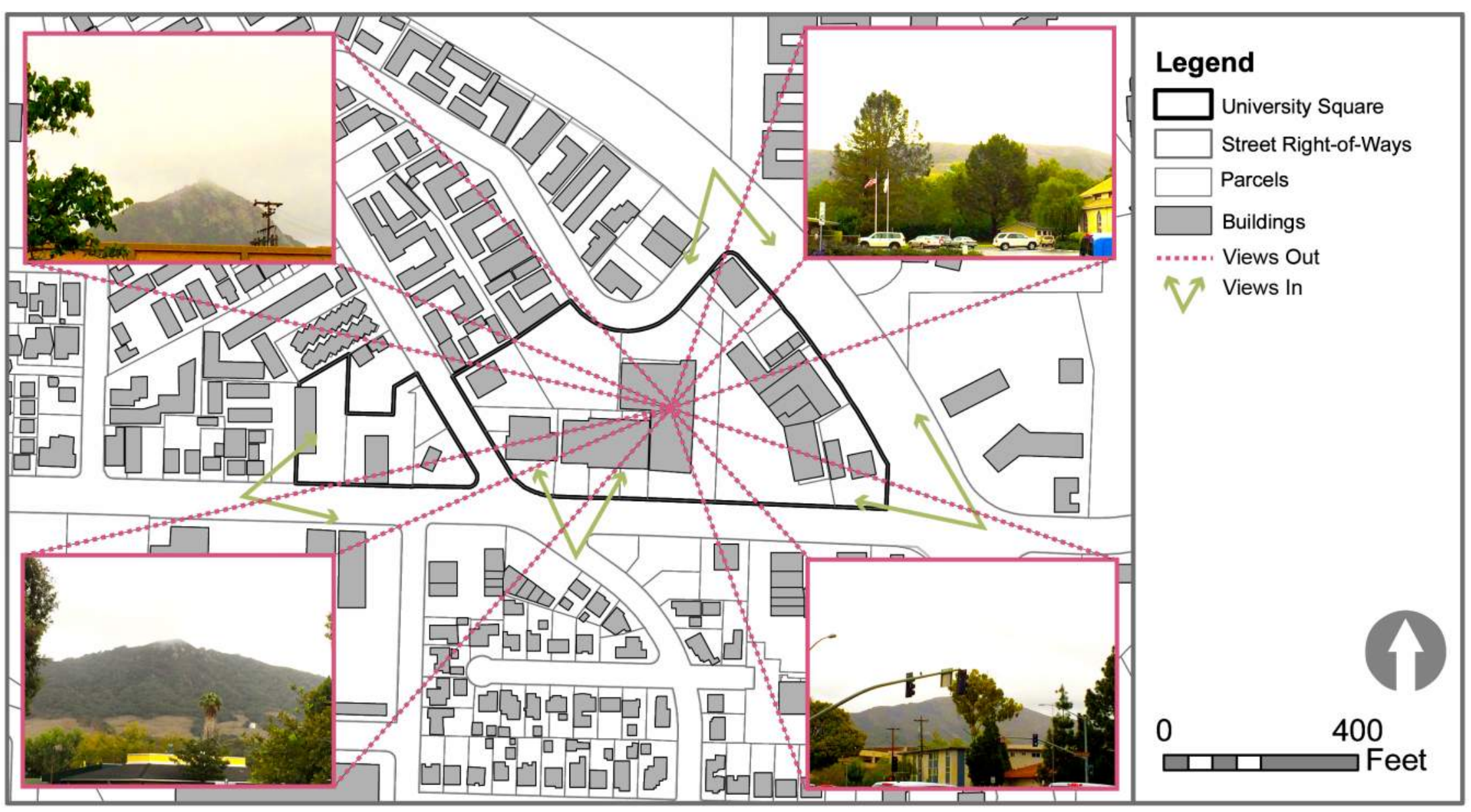




\subsection{CLIMATE AND SOLAR ORIENTATION}

The local San Luis Obispo climate is temperate, with average annual temperatures between $49^{*}$ and $69^{*} \mathrm{~F}$ (CA NCDC, 2010). Table 3.4 projects the average annual precipitation in blue, average minimum temperature in green, average temperature in orange, and average maximum temperature in red from 1981 to 2010. Though temperate, it does get hot, particularly during summer months when highs can get into the 90's. Proposed development at University Square should take this into account and adequate shade should be provided.

Figure 3.16 shows the solar orientation on buildings 4,5,6, and 7 during four times of the year and three times per day. This diagram shows that shadow lengths coming from vertical elements on the site vary throughout the year and time of day. During the Winter Solstice and Fall (October 31st) the north side of the site remains shadowed. Whereas, during the Summer Solstice and Spring (March 30th) the East side of the site remains shadows. This will effect the interior and exterior climates of the buildings and their energy consumption, and the comfort of outdoor spaces.

Outdoor spaces would be best on the west and south sides of buildings and other vertical elements. Windows should also face south to take advantage of daylighting, and shading may needed on the east, west, and south elevations of buildings.

TABLE 3.4 - San Luis Obispo Climate (from 1981-2010), Source: CA NCDC, 2010

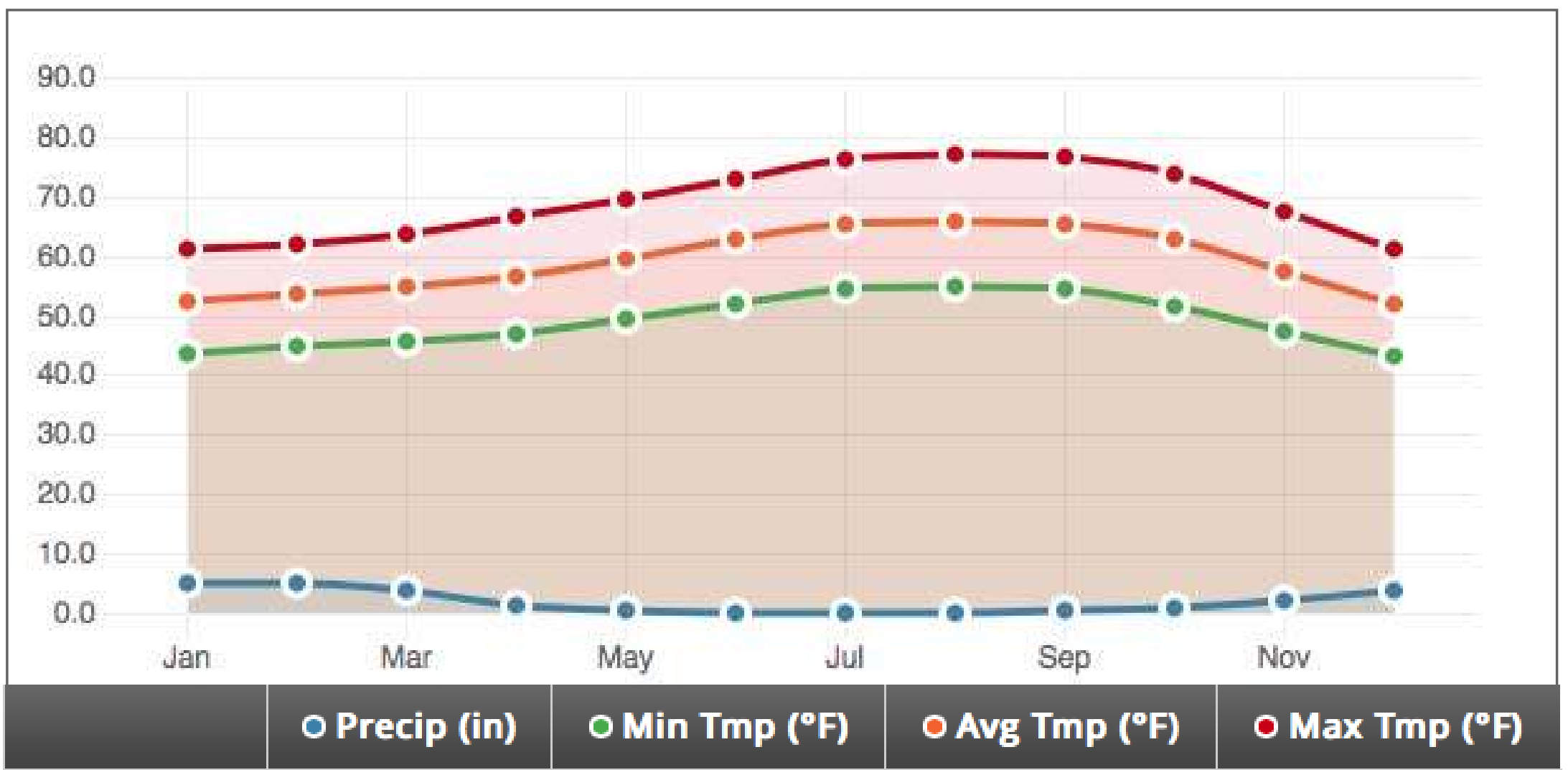


WINTER SOLSTICE

DECEMBER 21st

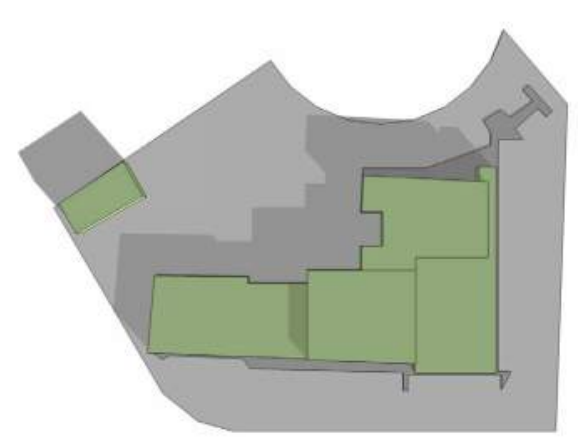

8 A.M.
SPRING

MARCH 30TH

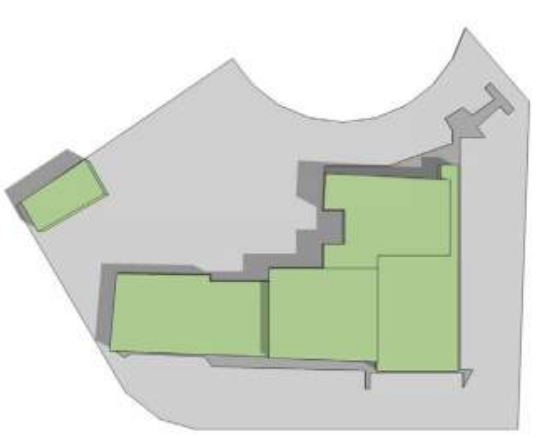

SUMMER SOLSTICE

JUNE $21 \mathrm{sT}$

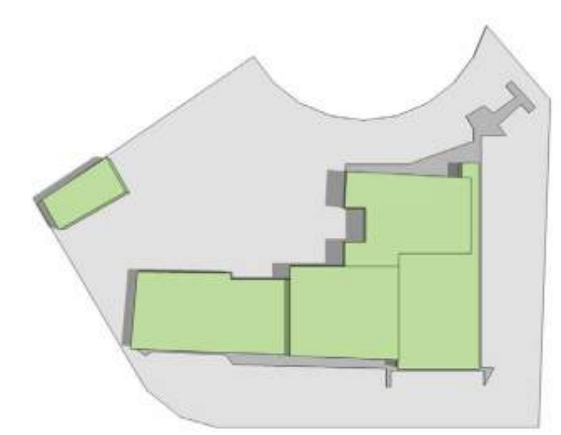

FALL

OCTOBER 31st

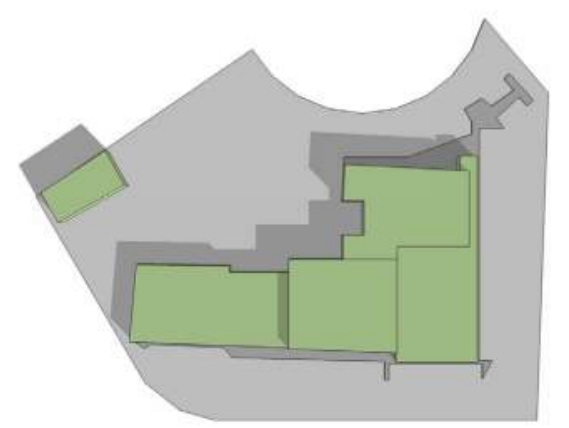

12 P.M.
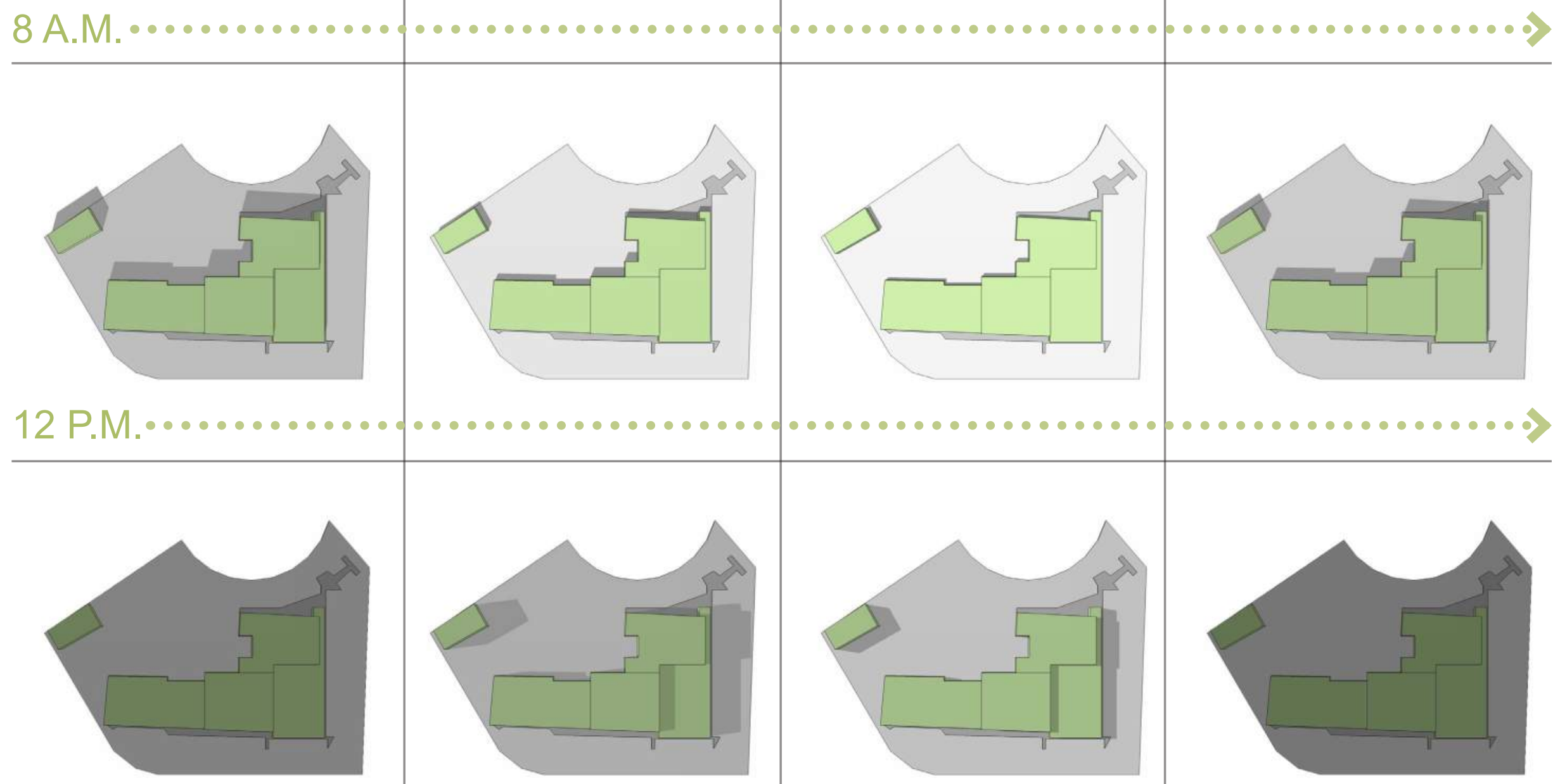

4 P.M.

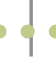

$\circ \circ \circ$

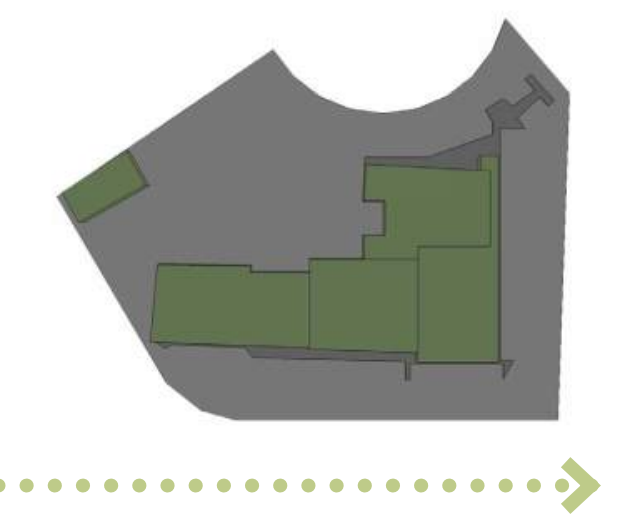




\subsection{MARKET ASSESSMENT}

This section explores the local student housing, multi-family residential, retail, and mixed-use real estate markets in San Luis Obispo, and how they relate to the University Square Site.

\subsubsection{Student Housing Market}

Student housing in San Luis Obispo is in high-demand. The current market for student housing is split between the University's limited on-campus rentals and the surrounding communities rental markets. Cal Poly currently houses around 6,300 beds in nine residence halls and two apartment-style complexes, which accommodates approximately 32 percent of the University's total student enrollment (Lazier, 2013). The City of San Luis Obispo absorbs the majority of the overflow into its rental market of approximately 11,500 renter-occupied units (U.S. Census, ACS 2011, 5 year).

Cal Poly has responded to increased demand with new on campus housing units such as Poly Canyon Village, a mixed-use development with living space for 2,600 students that opened in 2009, (Lazier, 2013). Poly Canyon units are four-bedroom and five-bedroom ranging from 936 - 1,175 square feet. Student housing fees for 9-month "leases" of $\$ 842.50$ for single rooms, and $\$ 646.50$ for shared rooms (Cal Poly University Housing, 2014.) Although Poly Canyon Village serves the student population, it fails to meet the total demand for student housing, and are not seen as direct competition with University Square due to their on-campus location.

The only large private student housing development in close proximity to campus is Mustang Village, which sits directly across Highway 1 from the Site (See Figure 3.5 for location). Mustang Village would be the direct competition for the local student housing market. Figure 3.17 shows typical floor plans for one-bedroom, two-bedroom, and three-bedroom apartments. One-bedroom (one-bath) apartments are 506 square feet, and rent for $\$ 998$ per/month (sharing a room is assumed at $\$ 499$ per student). Two-bedroom (one-bath) apartments are 830 square feet, and rent for $\$ 1,676$ (sharing a room is assumed at $\$ 419$ per student). Three-bedroom (two-bath) apartments are 1,135 square feet, and rent for $\$ 2,123$ (sharing costs are not assumed). All data retrieved from MustangVillage.com on April 29, 2014.

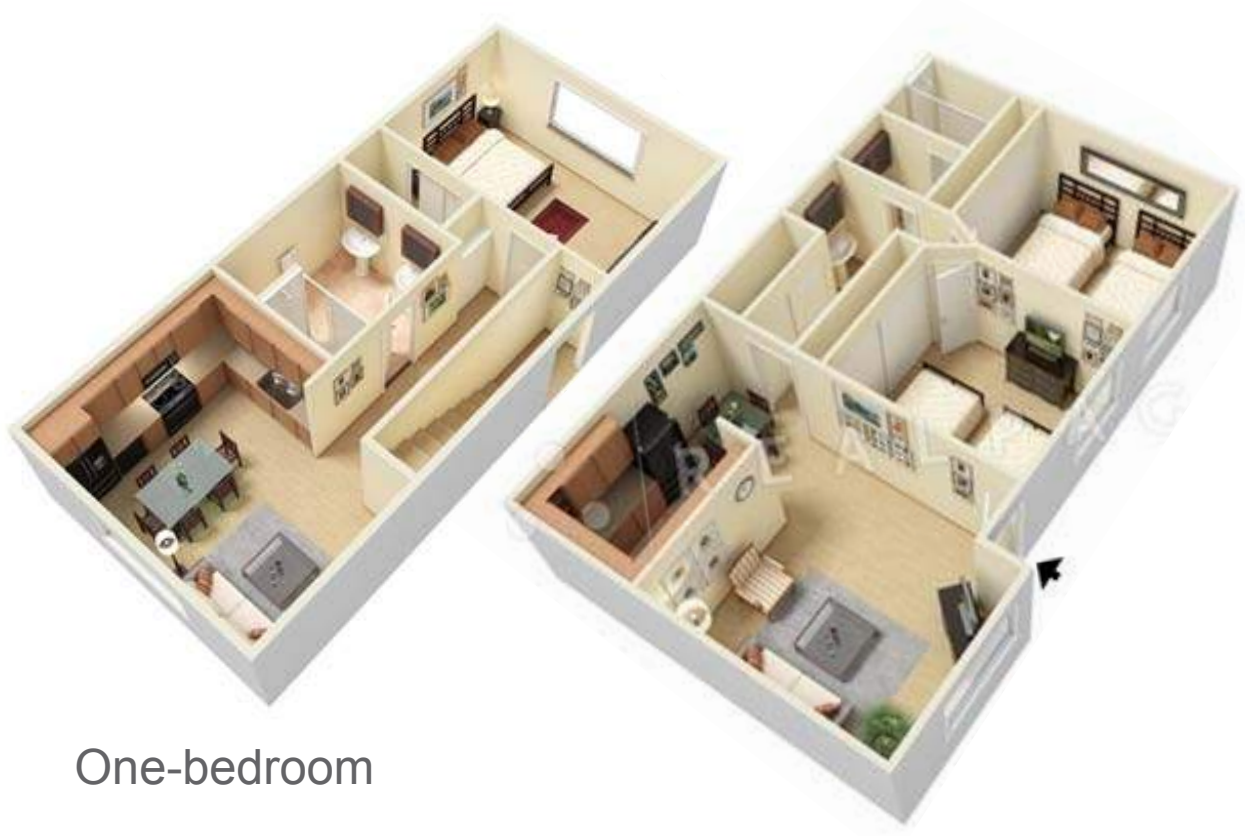

Two-bedroom

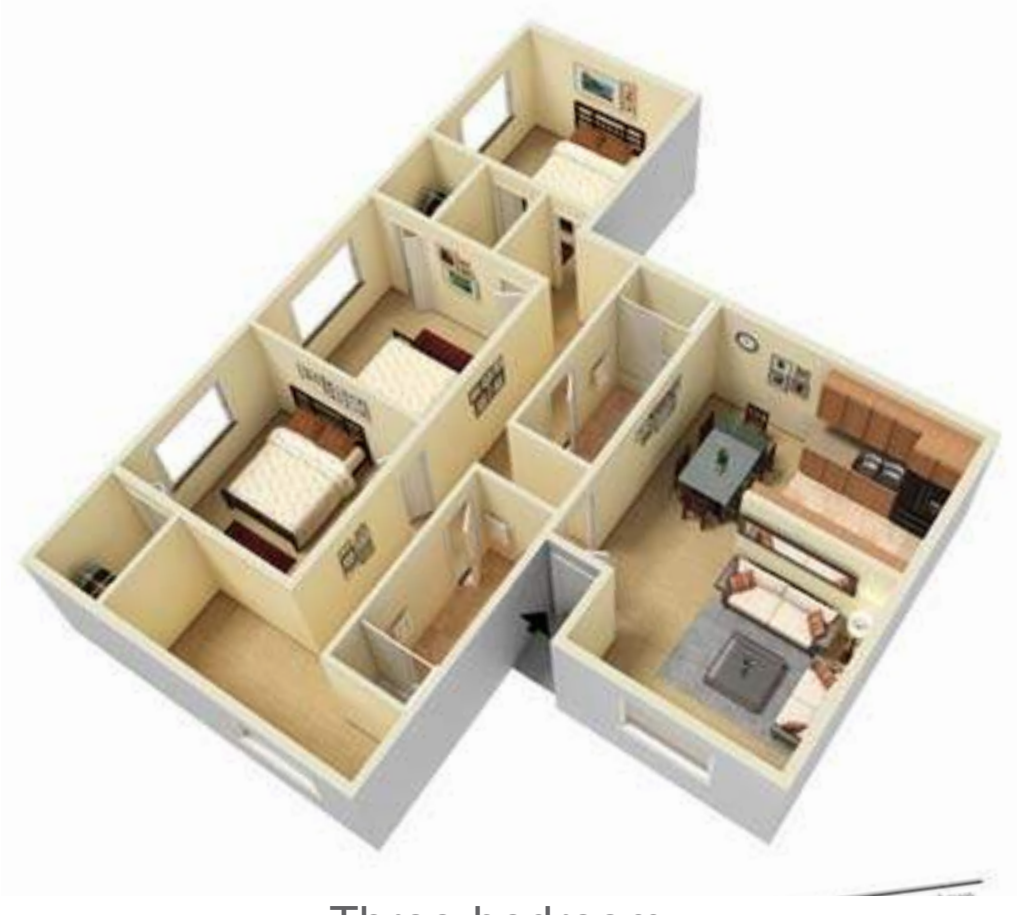

Three-bedroom 
Both the multi-family rental and buyer markets are robust in San Luis Obispo. New units coming on to the market are mostly high-end condominiums such as the Marsh Street Commons in downtown San Luis Obispo. Floor plans for units range from 1,623-1,869 square feet and sell in the mid to high $\$ 600,000$ 's (richardsonproperties.com, 2014). Although University Square is advantaged by an excellent location and views, it is not envisioned as a destination for luxury living. The proximity to Cal Poly along with the relative distance from the downtown preclude luxury development similar to Marsh Street Commons at the site. Any condominium units at the site will likely be

Table 3.5 shows multi-family days on the market and sales trend for San Luis Obispo County. The median days on the market is at a 5-year low with properties averaging 100-105 days. Sales prices for the County on the other hand are relatively low, with median prices at $\$ 175,000$ (data obtained from Looopnet.com, 2014). However, the City of San Luis Obispo has historically recorded the highest real estate prices in the entire county and is seen as having more robust sales potential.

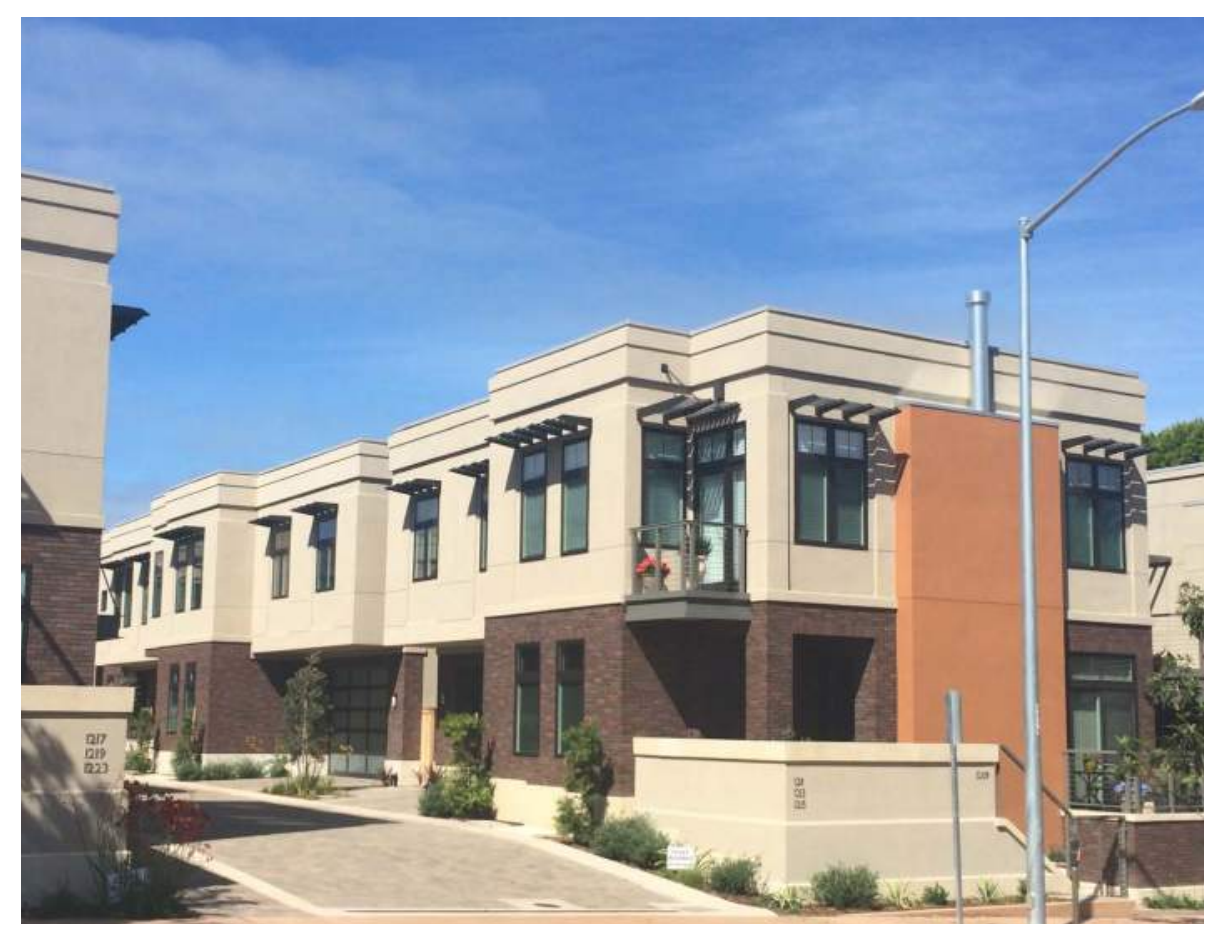

TABLE 3.5 - San Luis Obispo Multi-Family Trends. Source: Loopnet.com, 2014

\section{Multifamily Property Days on Market - Sale Trends}

Median Days on Market Multifamily for Sale San Luis Obispo-Paso Robles, CA

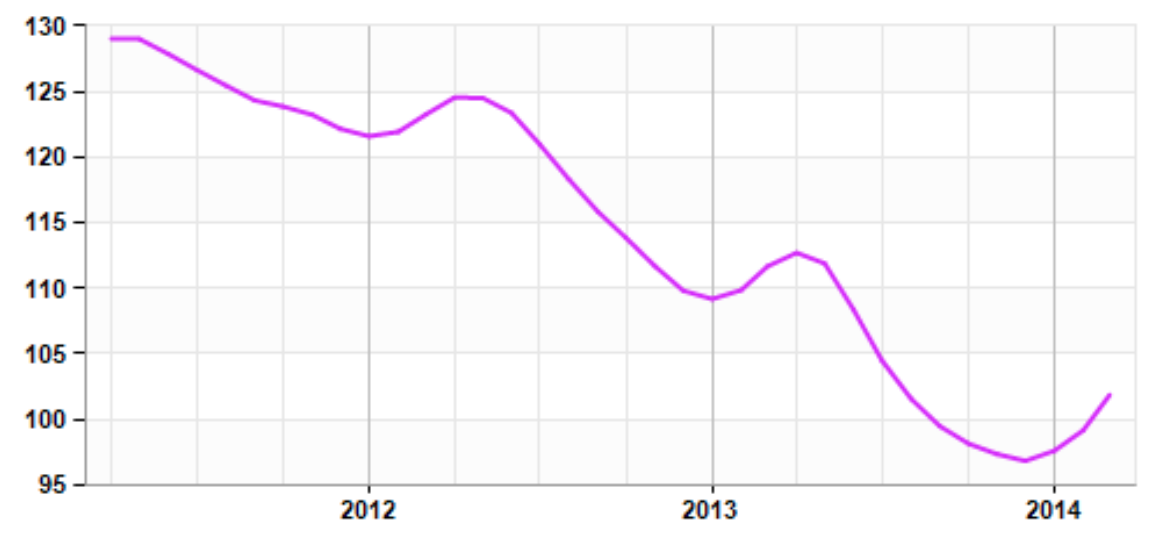

\section{Multifamily Property Sale Prices - Sale Trends}

Median Sale Price Multifamily San Luis Obispo-Paso Robles, CA (\$/Unit)

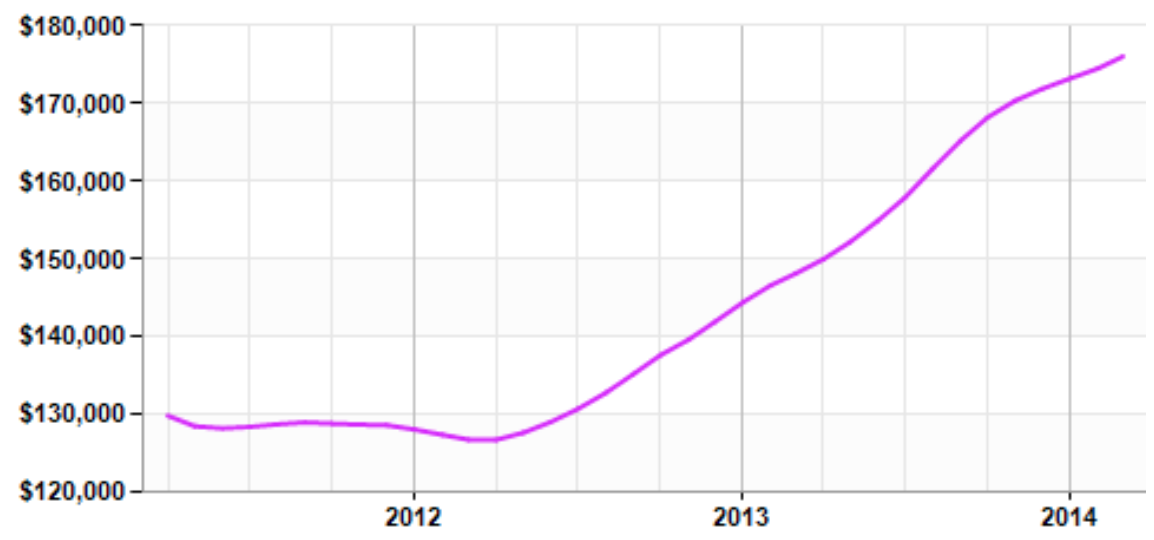


New retail development at the Site should consider the retention of existing tenants. Approximately 50,000 square feet of the Slte is currently retail tenants. It is assumed that at least this much retail can continue on the Site, and improved retail space can lead to higher sales and/or rent prices. Table 3.6 shows median retail sales prices for San Luis Obispo County. Although the median sits at $\$ 210$ per square foot, the City of San Luis Obispo has historically recorded the highest real estate prices in the entire county and is seen as having more robust retail property sales potential.

The local retail market is not completely saturated and leaves room for new retail opportunities. The area surrounding University Square and Cal Poly is limited in terms of Commercial activity. Highway 101 to the south, and Cerro San Luis and Bishops Peak to the West act as physical barriers and create more isolated shopping patterns. The only nearby grocery retailer, Albertsons, is only 18,327 square feet, and does not fully absorb the demand from students and local neighborhoods. Another, more high-end grocery retailer such as a Trader Joe's or small Whole Foods could be very successful in the area and would be well positioned at University Square. Additional retail opportunities at the Site include food and entertainment uses. Currently most dining and entertainment opportunities occur in the City's downtown, and new options would be welcomed closer to campus. Also small and medium retailers could work at University Square. This could include speciality retailers, personal services, banking services, health and fitness centers, and medium size consumer retailers.

\subsubsection{Mixed-Use Market}

Data for the local mixed-use market is difficult to obtain because it is integrated into multi-family and commercial (office and retail) analyses. However, there are several local mixed-use projects that can be analyzed as analogous to the mixed-use typology proposed at University Square. The Mix at Monterrey is a relatively new development that includes residential, office, and retail uses about two miles from University Square. Although much smaller than the total area of University Square, the Mix at Monterrey has shown that threestoried mix-use can be successful in San Luis Obispo, and that contemporary architecture can be integrated into the historic context of the City.

\section{Retail Property Sale Prices - Sale Trends}

\section{Median Sale Price Retail San Luis Obispo-Paso Robles, CA (\$/SF)}

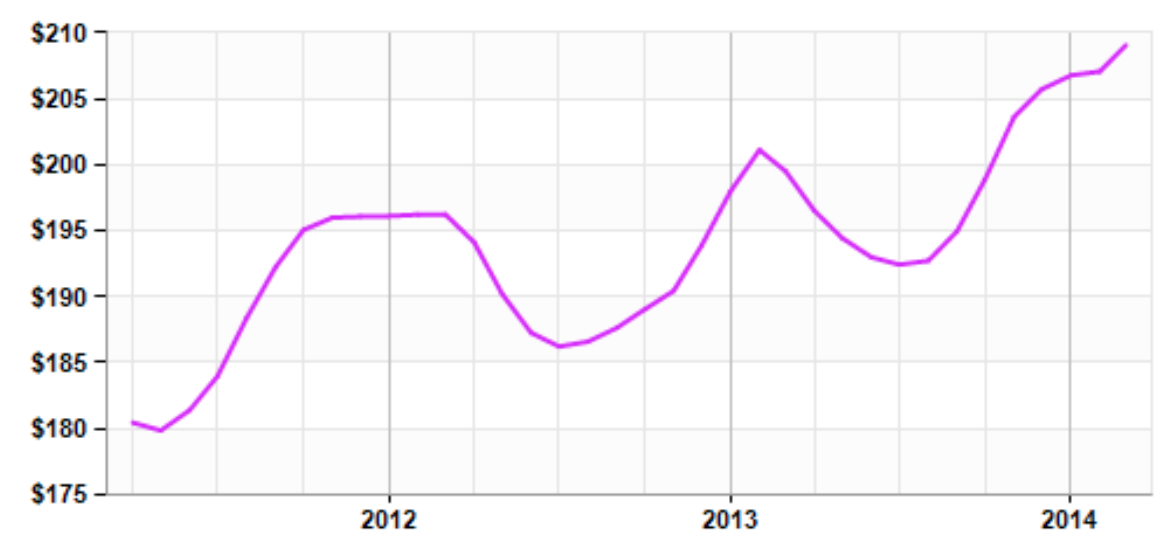

Perhaps, the most analogous project to University Square is the Village at Broad Street. This project contains a mix of uses on the site including multifamily residential, retail (including a small market), and office. The total site is approximately 5.85 acres with the largest structure containing over 42,000 square feet of three-story affordable multi-family housing, over 7,500 square feet of ground floor retail (ROEM Corporation, roemcorp.com, 2014). The project has proven very successful and demonstrates the demand for multistoried mixed-use within the City. 

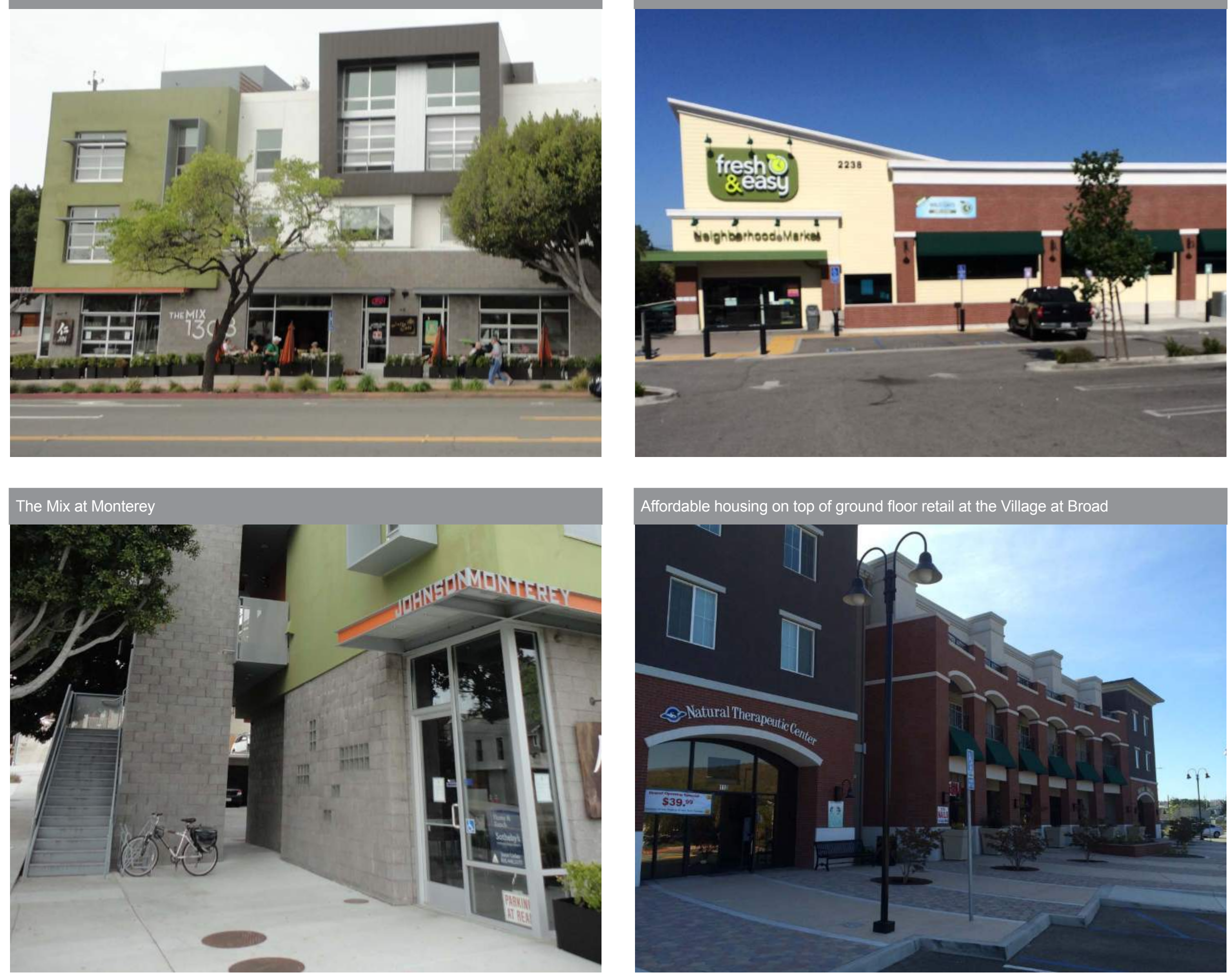

Affordable housing on top of ground floor retail at the Village at Broad

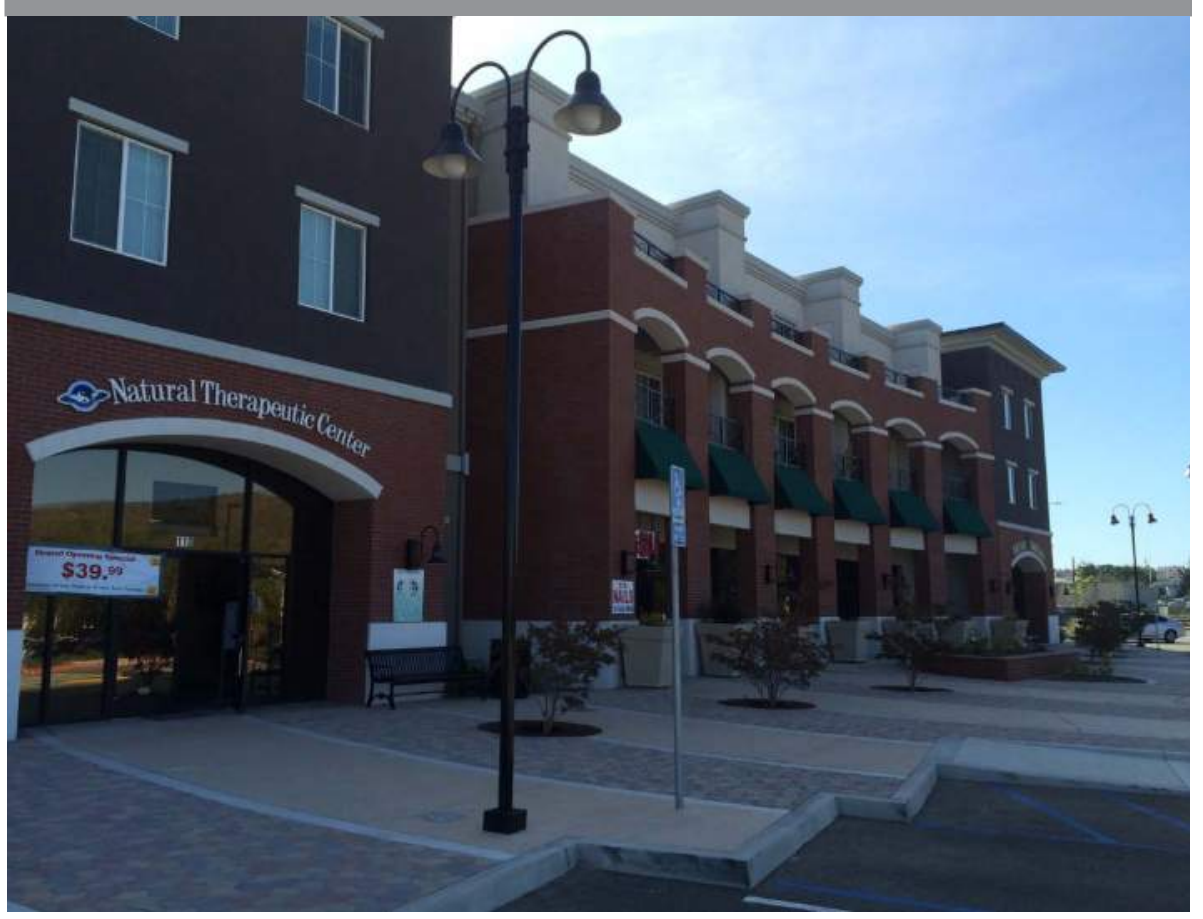




\subsection{CONCLUSION}

Generally speaking the University Square Site has a lot of potential. It remains in a moderately warm climate, with excellent views, access to public transit, and retains a strong market. However, there are many aspects of the Site that are in need of improvements, including the vehicular and non-vehicular circulation patterns, improved connections with the surrounding neighborhoods, and the undergrounding of some utilities. Additionally, most or all of the existing structures will likely need demolishing and replacement. Figure 3.18 is a perception matrix which ranks the Site's attributes on a sliding scale, with 1 indicating a poor performance, 2 indicating a fair performance, and 3 indicating a good performance.

Some of the foreseeable constraints to development include the Site's current multiple parcel ownerships, and the interior wastewater main and manhole. These constraints are not seen as unremediable, and Sections 5.0: Project Development and 6.0: Financing, provide strategies that directly address and/or mitigate these considerations.

FIGURE 3.18 - Perception Matrix

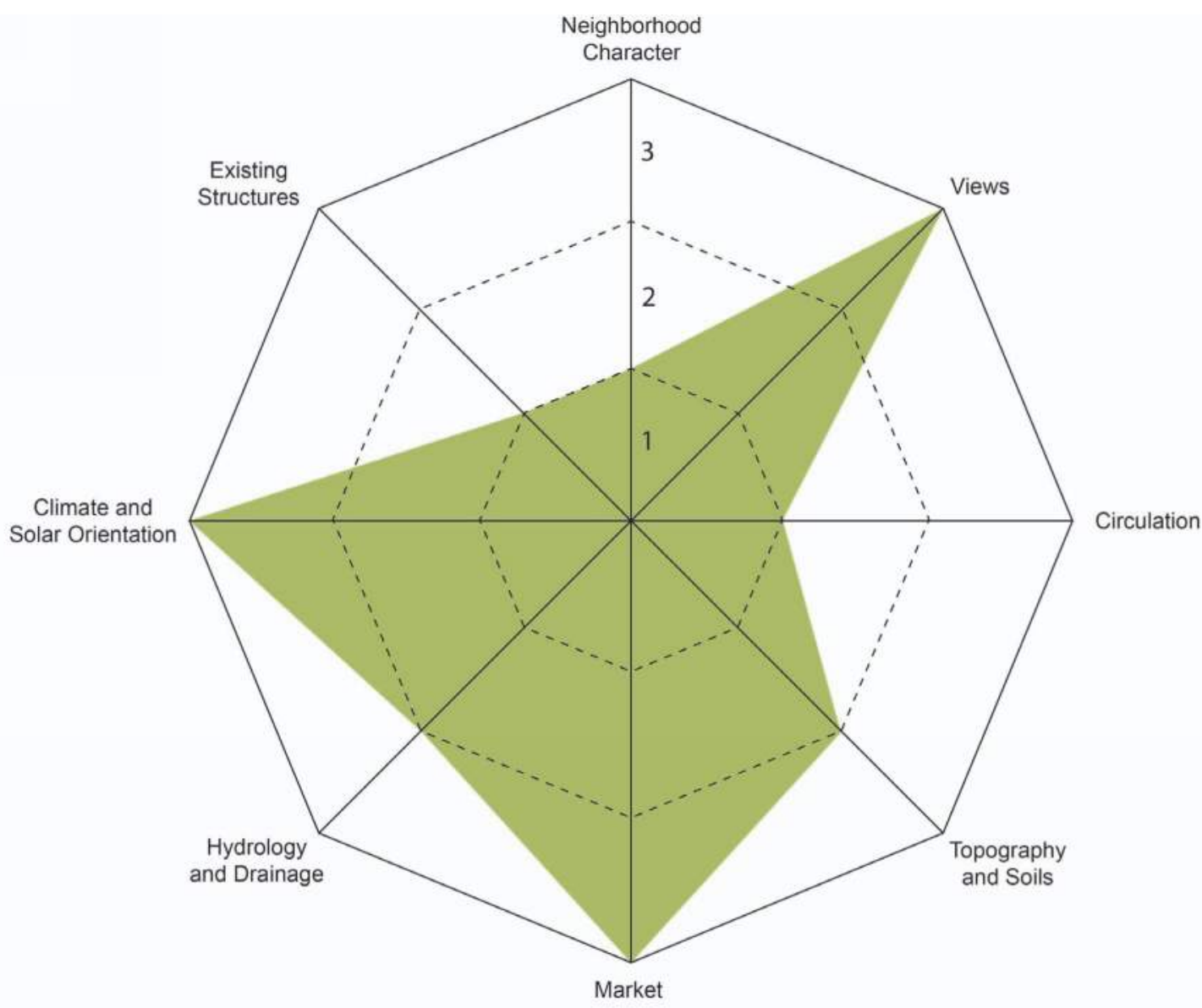


THIS PAGE INTENTIONALLY LEFT BLANK 


\section{PROGRAM DEVELOPMENT}

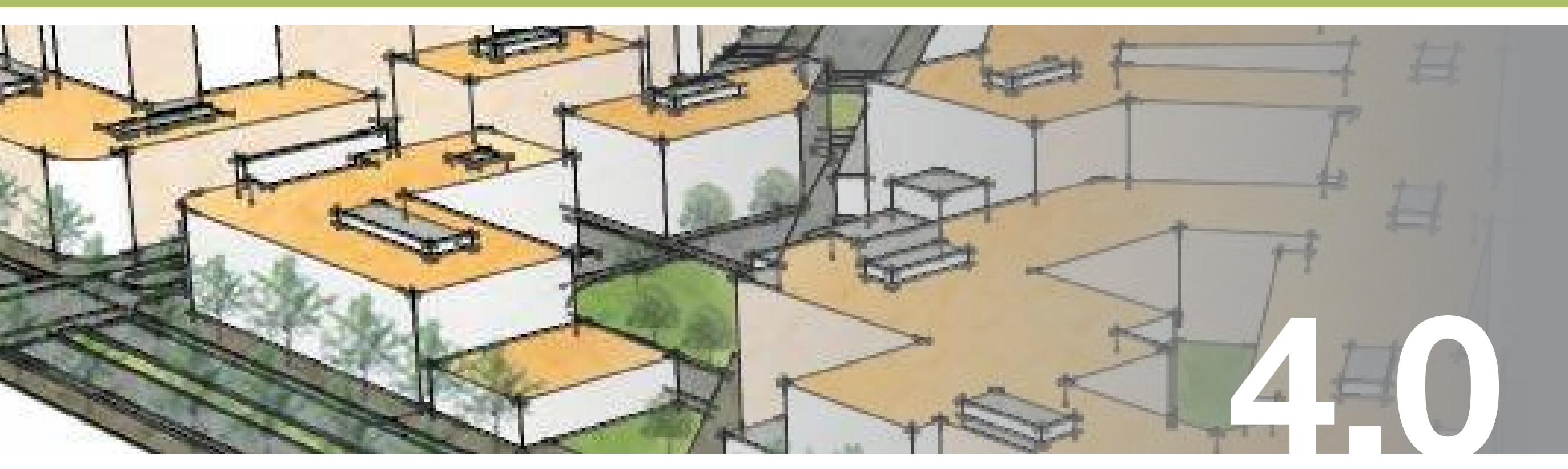


THIS PAGE INTENTIONALLY LEFT BLANK 


\subsection{PROGRAM GOALS}

The Site's current state leaves it ripe for redevelopment and creates an opportunity for a landmark project that provides additional housing, services, and amenities for Cal Poly, the City, and the region. This program provides specific uses for the Site, descriptions, functions and quantities. Specific program goals includes:

Goal 1: The provision of approximately 500 new student beds.

Goal 2: The provision of quality condominiums.

Goal 3: The provision of retail space.

Goal 4: An adequate amount of parking for all uses on the Site.

Goal 5: The provision of public spaces.

\subsection{STUDENT HOUSING}

The unit mix for student housing was determined through the preferences of the student population, namely individuals seeking to live alone or in small groups. Furthermore, the unit mix matches existing market typologies for both on and off campus student housing in San Luis Obispo. With a goal of providing approximately 500 student beds, the unit mix consists of 50 one-bedroom apartments, 80 two-bedroom apartments, and 80 three-bedroom apartments. With an average population factor of 1.25 persons per bedroom, these 210 units provide 563 new student beds. Table 4.1 provides general floor plan square footages and totals for the student apartments.

\subsection{CONDOMINIUMS}

With a high demand for new product in San Luis Obispo and changing demographics and housing needs, the Site provides an excellent opportunity for new condominiums. The unit mix was determined by examining average household sizes for the City and by examining the market assessment in Section 3.12 . The 2011 American Community Survey 5-year estimates an average of 2.43 persons per household, and most condominiums in the area remain two to threebedrooms (or two-bedroom with office). The condominium unit mix for University Square is split between 50 two-bedroom units, and 50 three-bedroom units. With an average population factor of 2.43 persons per household, these 100 units provide new homes for 243 persons. Table 4.2 provides general floor plan square footages and totals for the condominiums. 


\begin{tabular}{|c|c|c|c|c|c|c|c|c|c|c|c|}
\hline STUDENT APARTMENTS & $\begin{array}{c}\text { BED } \\
\text { ROOM } \\
13^{\prime} \times 11^{\prime}\end{array}$ & $\begin{array}{l}\text { LIVING } \\
\text { ROOM } \\
15^{\prime} \times 11^{\prime}\end{array}$ & $\begin{array}{l}\text { DINING } \\
\text { ROOM } \\
10^{\prime} \times 70^{\prime}\end{array}$ & $\begin{array}{c}\text { KITCHEN } \\
12^{\prime} \times 8^{\prime}\end{array}$ & $\begin{array}{r}\text { BATH } \\
10^{\prime} \times 5^{\prime}\end{array}$ & $\begin{array}{l}\text { CLOSET } \\
10^{\prime} \times 5^{\prime}\end{array}$ & $\begin{array}{c}\text { TOTAL } \\
\text { W/O } \\
\text { BALCONY } \\
\text { (sq. ft.) }\end{array}$ & $\begin{array}{c}\text { BALCONY } \\
10^{\prime} \times 5^{\prime}\end{array}$ & $\begin{array}{c}\text { TOTAL } \\
\text { UNIT } \\
\text { (sq.ft.) }\end{array}$ & $\begin{array}{l}\text { NO OF } \\
\text { UNITS }\end{array}$ & $\begin{array}{c}\text { TOTAL } \\
\text { SQUARE } \\
\text { FOOTAGE }\end{array}$ \\
\hline APARTMENT - 1 BEDROOM & 143 & 165 & 70 & 96 & 50 & 50 & 574 & 50 & 624 & 50 & 31,200 \\
\hline APARTMENT - 2 BEDROOM & 286 & 165 & 70 & 96 & 50 & 100 & 767 & 50 & 817 & 80 & 65,360 \\
\hline APARTMENT - 3 BEDROOM & 429 & 165 & 70 & 96 & 100 & 150 & 1,010 & 100 & 1,110 & 80 & 88,800 \\
\hline SUB-TOTAL & - & - & - & - & - & - & - & - & - & 210 & 185,360 \\
\hline $\begin{array}{l}\text { CIRCULATION - } 20 \% \text { OF } \\
\text { TOTAL AREA }\end{array}$ & - & - & - & - & - & - & - & - & - & - & 37,072 \\
\hline $\begin{array}{l}\text { SERVICE AREAS - 5\% OF } \\
\text { TOTAL AREA }\end{array}$ & - & - & - & - & - & - & - & - & - & - & 9,268 \\
\hline TOTAL & - & - & - & - & - & - & - & - & - & - & 231,700 \\
\hline
\end{tabular}

TABLE 4.2 - Condominium Floor Plans and Areas

\begin{tabular}{|c|c|c|c|c|c|c|c|c|c|c|c|c|c|c|}
\hline CONDOMINIUMS & $\begin{array}{c}\text { BED } \\
\text { ROOM } \\
13^{\prime} \times 11^{\prime}\end{array}$ & $\begin{array}{c}\text { MASTER } \\
\text { BEDROOM } \\
\text { 16'X14' }\end{array}$ & $\begin{array}{l}\text { LIVING } \\
\text { ROOM } \\
15^{\prime} \times 18^{\prime}\end{array}$ & $\begin{array}{l}\text { DINING } \\
\text { ROOM } \\
15^{\prime} \times 7^{\prime}\end{array}$ & $\begin{array}{l}\text { KITCHEN } \\
16^{\prime} \times 10^{\prime}\end{array}$ & $\begin{array}{l}\text { BATH } \\
10^{\prime} \times 5^{\prime}\end{array}$ & $\begin{array}{c}\text { MASTE } \\
\text { R BATH } \\
8^{\prime} \times 14^{\prime}\end{array}$ & $\begin{array}{l}\text { CLOSET } \\
10^{\prime} \times 5^{\prime}\end{array}$ & $\begin{array}{c}\text { TOTAL } \\
\text { W/O } \\
\text { BALCONY } \\
\text { (sq. ft.) }\end{array}$ & $\begin{array}{l}\text { BALCONY } \\
10^{\prime} \times 5^{\prime}\end{array}$ & $\begin{array}{l}\text { BALCONY } \\
16^{\prime} \times 10^{\prime}\end{array}$ & $\begin{array}{l}\text { TOTAL } \\
\text { (sq.ft.) }\end{array}$ & $\begin{array}{l}\text { NO OF } \\
\text { UNITS }\end{array}$ & $\begin{array}{c}\text { TOTAL } \\
\text { SQUARE } \\
\text { FOOTAGE }\end{array}$ \\
\hline $\begin{array}{l}\text { CONDO - } 2 \\
\text { BEDROOM }\end{array}$ & 143 & 224 & 165 & 105 & 160 & 100 & 112 & 100 & 1,109 & 100 & - & 1,209 & 50 & 60,450 \\
\hline $\begin{array}{l}\text { CONDO - } 3 \\
\text { BEDROOM }\end{array}$ & 286 & 224 & 165 & 105 & 160 & 150 & 112 & 150 & 1,352 & 50 & 160 & 1,562 & 50 & 78,100 \\
\hline SUB-TOTAL & - & - & - & - & - & - & - & - & - & - & - & - & 100 & 138,550 \\
\hline $\begin{array}{l}\text { CIRCULATION - } \\
20 \% \text { OF TOTAL } \\
\text { AREA }\end{array}$ & - & - & - & - & - & - & - & - & - & - & - & - & - & 27,710 \\
\hline $\begin{array}{c}\text { SERVICE AREAS - } \\
8 \% \text { OF TOTAL AREA }\end{array}$ & - & - & - & - & - & - & - & - & - & - & - & - & - & 11,084 \\
\hline$\overline{\text { TOTAL }}$ & - & - & - & - & - & - & - & - & - & - & - & - & - & 177,344 \\
\hline
\end{tabular}


The goal of retail at the Site is to provide new shopping, dining, and recreation options to residents and visitors. The specific use of mixes was determined through the market assessment in Section 3.12, and includes 2 small-sized retail stores (3,000 sq. ft. each), 2 medium-sized retail stores (4,500 sq. ft. each), 1 large-sized retail store (6,000 sq. ft.), 1 medium-sized market (around the size of a Trader Joe's, 15,000 - 20, 000 sq. ft.), 5, café sized restaurants (1,800 sq. ft. each, serving approximately 60 customers), 1 medium-sized restaurant (4,000 sq. ft., serving approximately 160 customers) and 1 gym (15,000 sq. ft.)

Appropriate uses included specialty stores and services, food services, a market, and recreational facilities. Retail floor plans can be re-configured to combine two or more stores to make room for larger uses. The City of San Luis Obispo, in updating the Land Use and Circulation Elements (LUCE) of the General Plan, has included specific language stating that the aforementioned uses are desirable for the area but that movie theaters, nightclubs, bars/taverns, and restaurants serving alcohol after 11 pm shall be prohibited (San Luis Obispo City Council Recommended Draft Land Use and Circulation Element update, 1/28/14,pg. 1-137).

\subsection{PARKING}

As with every large project, parking remains a challenge at the University Square Site. If parking requirements were determined purely by use, the total number of parking spaces that the City would require amounts to 1,067 spaces. At 300 square feet per space (including drive aisles and room for the structure) there would need to be 320,100 square feet or approximately 7.3 total acres of parking. This requirement would be untenable for a project site of 8.2 acres. Thankfully, the University Square Site may be eligible for both specialized parking reductions and mixed-use parking reductions.

The City of San Luis Obispo, in updating the Land Use and Circulation Elements (LUCE) of the General Plan, has included specialized site parking reductions for the University Square Site. As part of the project the section states: "the City will evaluate adjustments to parking requirements to account for predominant pedestrian and bike access." Parking reductions also come from the San Luis Obispo Municipal Code 17.16.060 Parking space requirements: B. Shared Parking Reduction, C. Mixed-Use Parking Reduction, and E. Automobile Trip Reduction. The Shared Parking Reduction states: "Where two or more uses share common parking areas, the total number of parking spaces required may be reduced by up to ten percent, with approval of an administrative use permit. Where shared parking is located on more than one parcel, affected parties must record an agreement governing the shared parking, to the satisfaction of the director."

The Mixed-Use Parking Reduction states: "By approving an administrative use permit, the director may reduce the parking requirement for projects sharing parking by up to twenty percent, in addition to the shared parking reduction, for a total maximum parking reduction of thirty percent, upon finding that the times of maximum parking demand from various uses will not coincide.

The Automobile Trip Reduction states: "By approving an administrative use permit, the director may reduce the parking requirement for projects implementing non-auto travel, particularly for commuting, when it can be demonstrated that reduction of on-site parking will be safe, and will not be detrimental to the surrounding area or cause a decline in quality of life. The applicant shall provide reasonable justification for the reduction, including innovative project design, transportation demand management (TDM), or incentives, which will reduce single-occupant vehicle travel to and from the site.

The parking program for University Square utilizes each of these parking reduction strategies where applicable. Due to its five-minute walking location from Cal Poly, parking reductions at the Site are most maximized for student housing. Rather than providing the 330 spots required for multi-family units, the student 
housing portion of the project utilizes the 30 percent reduction strategy outlined in sections 17.16.60 B and C of the San Luis Obispo Municipal, combined with additional reductions from the updated LUCE and section 17.16.60 $\mathrm{E}$ for a total reduction of 50 percent. This translates to a total of 218 spaces, or 65,250 square feet of parking (300 square feet per space including drive aisles and room for the structure.)

Condominiums, retail, food, and entertainment uses are eligible for the 30 percent reduction from sections 17.16.60 B and C of the San Luis Obispo Municipal Code, as well as reductions from the updated LUCE that are estimated at 10 percent. These uses are foreseen as needing more parking than student housing with a total reduction of 40 percent. This translates to a total of 214 spaces, or 64,200 square feet of parking (300 square feet per space including drive aisles and room for the structure.) Table 4.3 contains the total number of spaces per use, as well as the total land area required for parking.

\subsection{PUBLIC SPACES AND RIGHTS-OF-} WAY

Adequate public space between buildings at University Square is necessary to provide residents and visitors opportunities for meeting people, playing, and watching the world go by. There is approximately 6.73 acres of developed land reserved for student housing, condominiums, retail, food, entertainment, and parking. The remainder of the Site (approximately 1.42 acres, 17\%) is dedicated to public space and rights-of-way. University Square seeks to be a pedestrian friendly environment, and vehicular rights-of-way will be limited to access points to and from the site. The public spaces will be vibrant and enriching and will help make connections throughout the site.

TABLE 4.3 - Parking

\begin{tabular}{|l|r|r|r|}
\hline \multicolumn{1}{|c|}{ PARKING } & $\begin{array}{l}\text { Size of spot w/ drive aisles } \\
\text { and room for sturcture, sq.ft. }\end{array}$ & $\begin{array}{l}\text { Total spaces per spot w/50\% or 40\% } \\
\text { reduction dependent on use }\end{array}$ & $\begin{array}{l}\text { Total sq.ft. w/50\% or 40\% } \\
\text { reduction dependent on use }\end{array}$ \\
\hline Apartment - 1 Bedroom & 300 & 38 & 11250 \\
\hline Apartment - 2 Bedroom & 300 & 80 & 24000 \\
\hline Apartment - 3 Bedroom & 300 & 100 & 30000 \\
\hline Condo - 2 Bedroom & 300 & 60 & 18000 \\
\hline Condo - 3 Bedroom & 300 & 60 & 18000 \\
\hline Retail Small & 300 & 12 & 3600 \\
\hline Retail Medium & 300 & 18 & 5400 \\
\hline Retail Big & 300 & 12 & 3600 \\
\hline Market & 300 & 30 & 9000 \\
\hline Café & 300 & 72 & 21600 \\
\hline Restaurant Medium & 300 & 40 & 12060 \\
\hline Gym & 300 & 30 & 9000 \\
\hline TOTAL & - & $\mathbf{5 5 2}$ & $\mathbf{1 6 5 5 1 0}$ \\
\hline
\end{tabular}




\subsection{THE PROGRAM}

TABLE 4.4 - The Program

\begin{tabular}{|c|c|c|c|c|c|c|c|c|c|c|}
\hline \multirow[t]{2}{*}{ LAND USE } & \multicolumn{2}{|r|}{ Land Area } & \multirow{2}{*}{$\begin{array}{c}\text { Ave Unit Size } \\
\text { (sq. ft.) }\end{array}$} & \multirow[t]{2}{*}{ No. Units } & \multirow[t]{2}{*}{$\begin{array}{l}\text { Ave no. } \\
\text { Storeys }\end{array}$} & \multirow{2}{*}{$\begin{array}{c}\text { Footprint } \\
\text { (acre) }\end{array}$} & Coverage & \multirow{2}{*}{$\begin{array}{c}\begin{array}{c}\text { Site } \\
\text { Coverage }\end{array} \\
\%\end{array}$} & \multirow[t]{2}{*}{$\begin{array}{l}\text { Ave. Pop. } \\
\text { Factor }\end{array}$} & \multirow[t]{2}{*}{$\begin{array}{l}\text { Resi. } \\
\text { Pop. }\end{array}$} \\
\hline & (acre) & (sq. ft.) & & & & & (sq. ft.) & & & \\
\hline \multicolumn{11}{|l|}{ Student Apartments } \\
\hline 1 Bedroom & 0.72 & 31,200 & 624 & 50 & $\overline{3}$ & 0.24 & 10,400 & - & 1.25 & 62.5 \\
\hline 2 Bedroom & 1.50 & 65,360 & 817 & 80 & 3 & 0.50 & 21,787 & - & 2.5 & 200 \\
\hline 3 Bedroom & 2.04 & 88,800 & 1110 & 80 & 3 & 0.68 & 29,600 & - & 3.75 & 300 \\
\hline Circulation - Corridors, Elevators, Lobby ( $20 \%$ of total area) & 0.85 & 37,072 & - & - & 3 & 0.28 & 12,357 & - & - & - \\
\hline Service Areas ( $5 \%$ of total area) & 0.21 & 9,268 & - & 4 & 3 & 0.07 & 3,089 & - & - & $\rightarrow$ \\
\hline TOTAL & 5.32 & 231,700 & - & 210 & - & 1.77 & 77,233 & $21.6 \%$ & - & 563 \\
\hline \multicolumn{11}{|l|}{ Condominiums } \\
\hline 2 Bedroom & 1.39 & 60,450 & 1209 & 50 & 3 & 0.46 & 20,150 & - & $2.43^{*}$ & 122 \\
\hline 3 Bedroom & 1.79 & 78,100 & 1562 & 50 & 3 & 0.60 & 26,033 & - & $2.43^{*}$ & 122 \\
\hline Circulation - Corridors, Elevators, Lobby ( $20 \%$ of total area) & 0.64 & 27,710 & -1 & - & 3 & 0.21 & 9,237 & - & - & - \\
\hline Service Areas ( $8 \%$ of total area) & 0.25 & 11,084 & - & - & 3 & 0.08 & 3,695 & - & - & \\
\hline TOTAL & 4.07 & 177,344 & - & 100 & - & 1.36 & 59,115 & $16.5 \%$ & - & 243 \\
\hline \multicolumn{11}{|l|}{ Retail, Food, and Entertainment } \\
\hline Retail Small & 0.14 & 6000 & 3000 & 2 & 1 & 0.14 & 6000 & - & - & - \\
\hline Retail Medium & 0.21 & 9000 & 4500 & 2 & 1 & 0.21 & 9000 & - & - & - \\
\hline Retail Big & \begin{tabular}{|c|c|}
0.14 \\
\end{tabular} & 6000 & 6000 & 1 & 1 & 0.14 & 6000 & - & - & -1 \\
\hline Market & 0.41 & 18000 & 18000 & 1 & 1 & 0.41 & 18000 & - & - & - \\
\hline Café & 0.21 & 9000 & 1800 & 5 & 1 & 0.21 & 9000 & - & - & - \\
\hline Restaurant Medium & 0.09 & 4000 & 4000 & 1 & 1 & 0.09 & 4000 & - & - & - \\
\hline Gym & 0.34 & 15000 & 15000 & 1 & 1 & 0.34 & 15000 & & & \\
\hline Back of House - Service and Delivery Areas (15\% of total area) & 0.23 & 10050 & - & - & 1 & 0.23 & 10050 & - & - & - \\
\hline TOTAL & 1.77 & 77050 & - & 13 & - & 1.77 & 77050 & $21.5 \%$ & - & \\
\hline Parking & & $\begin{array}{l}\mathrm{w} / 50 \% \text { or } 40 \% \text { Reduction } \\
\text { Dependent on Use }\end{array}$ & $\begin{array}{l}\mathrm{w} / \mathrm{drive} \text { aisles and } \\
\text { room for sturcture }\end{array}$ & \begin{tabular}{|l|}
$\mathrm{w} / 50 \%$ or $40 \%$ Reduction \\
Dependent on Use
\end{tabular} & & & & & & \\
\hline Apartment - 1 Bedroom & 0.26 & 11250 & 300 & 38 & $\overline{2}$ & 0.13 & 5,625 & - & - & - \\
\hline Apartment - 2 Bedroom & 0.55 & 24000 & 300 & 80 & 2 & 0.28 & 12,000 & - & - & - \\
\hline Apartment - 3 Bedroom & 0.69 & 30000 & 300 & 100 & 2 & 0.34 & 15,000 & - & - & - \\
\hline Condo - 2 Bedroom & 0.41 & 18000 & 300 & 60 & 2 & 0.21 & 9,000 & - & - & - \\
\hline Condo - 3 Bedroom & 0.41 & 18000 & 300 & 60 & 2 & 0.21 & 9,000 & - & - & - \\
\hline Retail Small & 0.08 & 3600 & 300 & 12 & 2 & 0.04 & 1,800 & & - & \\
\hline Retail Medium & 0.12 & 5400 & 300 & 18 & 2 & 0.06 & 2,700 & - & - & - \\
\hline Retail Big & 0.08 & 3600 & 300 & 12 & 2 & 0.04 & 1,800 & & - & \\
\hline Market & 0.21 & 9000 & 300 & 30 & 2 & 0.10 & 4,500 & & - & - \\
\hline Café & 0.50 & 21600 & 300 & 72 & 2 & 0.25 & 10,800 & & - & \\
\hline Restaurant Medium & 0.28 & 12060 & 300 & 40 & 2 & 0.14 & 6,030 & & - & \\
\hline Gym & 0.21 & 9000 & 300 & 30 & 2 & 0.10 & 4,500 & & & \\
\hline TOTAL & 3.80 & 165510 & - & 552 & - & 1.90 & \begin{tabular}{|l|}
82,755 \\
\end{tabular} & $23.1 \%$ & - & \\
\hline Public Space/R.O.W & 2.10 & & & & & & & & & \\
\hline TOTAL & 1.42 & 61,759 & - & - & - & 1.42 & 61,759 & $17.3 \%$ & - & - \\
\hline OVERALL TOTALS & 14.96 & 651,604 & & & & 8.22 & 357,912 & $100.0 \%$ & & 806 \\
\hline
\end{tabular}


THIS PAGE INTENTIONALLY LEFT BLANK 


\section{PROJECT DEVELOPMENT}

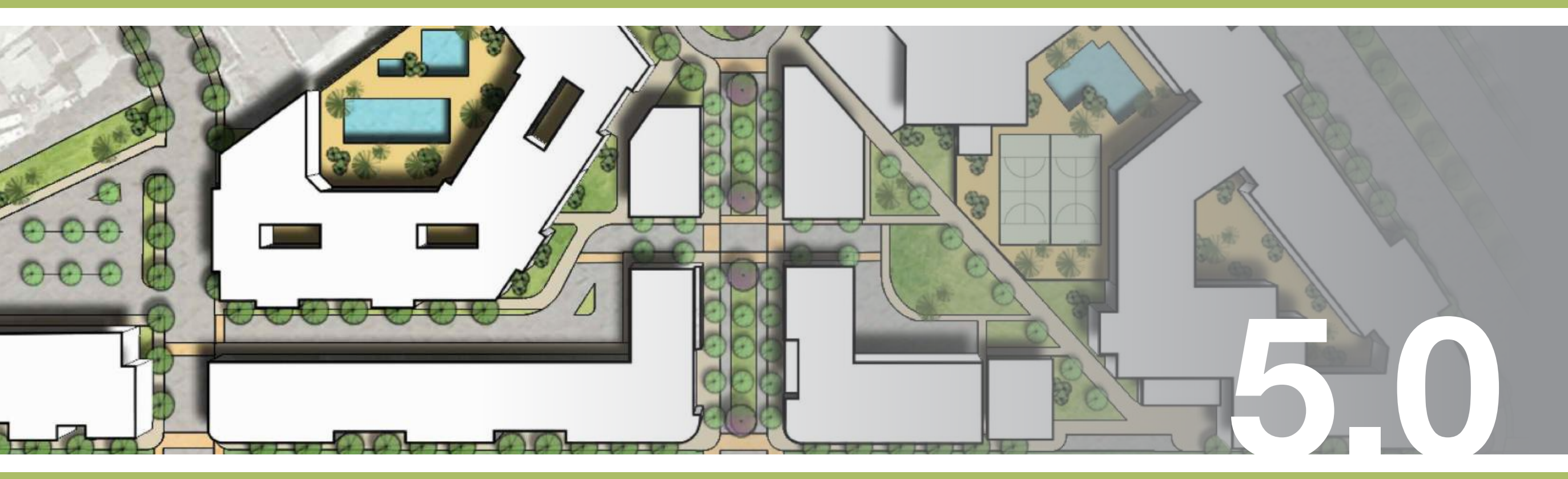


THIS PAGE INTENTIONALLY LEFT BLANK 


\subsection{DESIGN AND VISION}

This Section focuses on the physical design and vision for the site based on the conclusions from Section 3: Site Assessment, and the program goals from Section 4: Program Development.

\subsubsection{Design Options}

The design process recognized a number of design options for the Site, and various scenarios were explored during the project development. Four options were thoroughly explored, with their refinement lead to the vision described in Section 5.1.2. The idea of a central public space emerged early during this process as a necessity for the area. Although the Site currently lacks a focal point, the redevelopment of University Square is seen as the areas new center. The central public space could take the form of a plaza, park, or pedestrian oriented road. Figure 5.1 shows different design options that were explored on the Site. Option 1 and 2 explored the idea of a central plaza surrounded by retail with linear pedestrian connections running north to south and east to west. Options 3 and 4 looked at the realignment of Chorro Street through the site, and creating active public streetscapes. Option 3 also explored the realignment of Broad Street. These two realignments could provide new public space and would greatly improve local circulation.

Condominiums and student housing need physical separation due to noise and privacy. Whether a street or a plaza, the central public space would serve both students and condominium residents and could effectively separate the two. Highway 1/Santa Rosa Street is not envisioned as pedestrian oriented due to the high speed of travelling vehicles and noise, and all design options explored Foothill Boulevard as the primary retail corridor due to its existing commercial character. The existing transit stop was seen as an important asset for the Site, and each design option looked at making pedestrian and public space connections to the transit hub.

Parking options were challenging due to the intensity of development proposed on the Site. Design options 1, 3, and 4 include either parking podiums or underground parking, while a parking structure was looked at in option 2. The problems with structured parking include prohibitive cost, increased building heights, and inconvenient access for residents. Podium parking combines parking with building footprints, which decreases costs. It also provides direct access for residents to and from parking to their units.

\subsubsection{The University Square Development Proposal Vision}

The University Square Development Proposal Vision (USDP Vision) is an early take on redevelopment of the Site, and provides a design solution that accommodates student housing, condominiums, retail, and open space. The USDP Vision reimagines University Square as a new gateway to the City of San Luis Obispo for residents and visitors to live, play, and shop. The USDP Vision achieves the project objectives outlined in Section 1:

1) Feasibility: Achieve a financially feasible design and development solution for the University Square Site.

2) Sense of Place: Provide a design that rehabilitates the Site's image and creates a unique sense of place.

3) Multi-Modal Transportation: Create opportunities for residents and visitors to use alternative modes of transportation such as walking, bicycling, and transit.

4) Housing: Develop housing for both Cal Poly students and the local San Luis Obispo community.

5) Sustainability: Design with the natural environment in mind and provide sustainable solutions that negates the project's environmental impact and enhances the Site's environmental quality.

The USDP Vision focuses on housing, amenities, and pedestrian connections through the Site. Figures 5.2 and 5.3 show the USDP Vision and its key features. Student housing has been strategically located as close to Cal Poly as possible on the east side of the Site adjacent to Highway 1/Santa Rosa Street. The design envisions the housing as three stories on top of a podium parking structure that covers the majority of the buildings footprint for a total of 4 stories with a 50 foot building height (see Figure 5.5: Section A.) The building's corner at the intersection of Foothill Boulevard and Highway 1/Santa Rosa Street (seen in Figure 5.3 as callout \#4) is devoted to an 18,000 square foot market. This design features an enhanced street corner, and includes podium parking for student housing and the market. The streetscape along Highway 

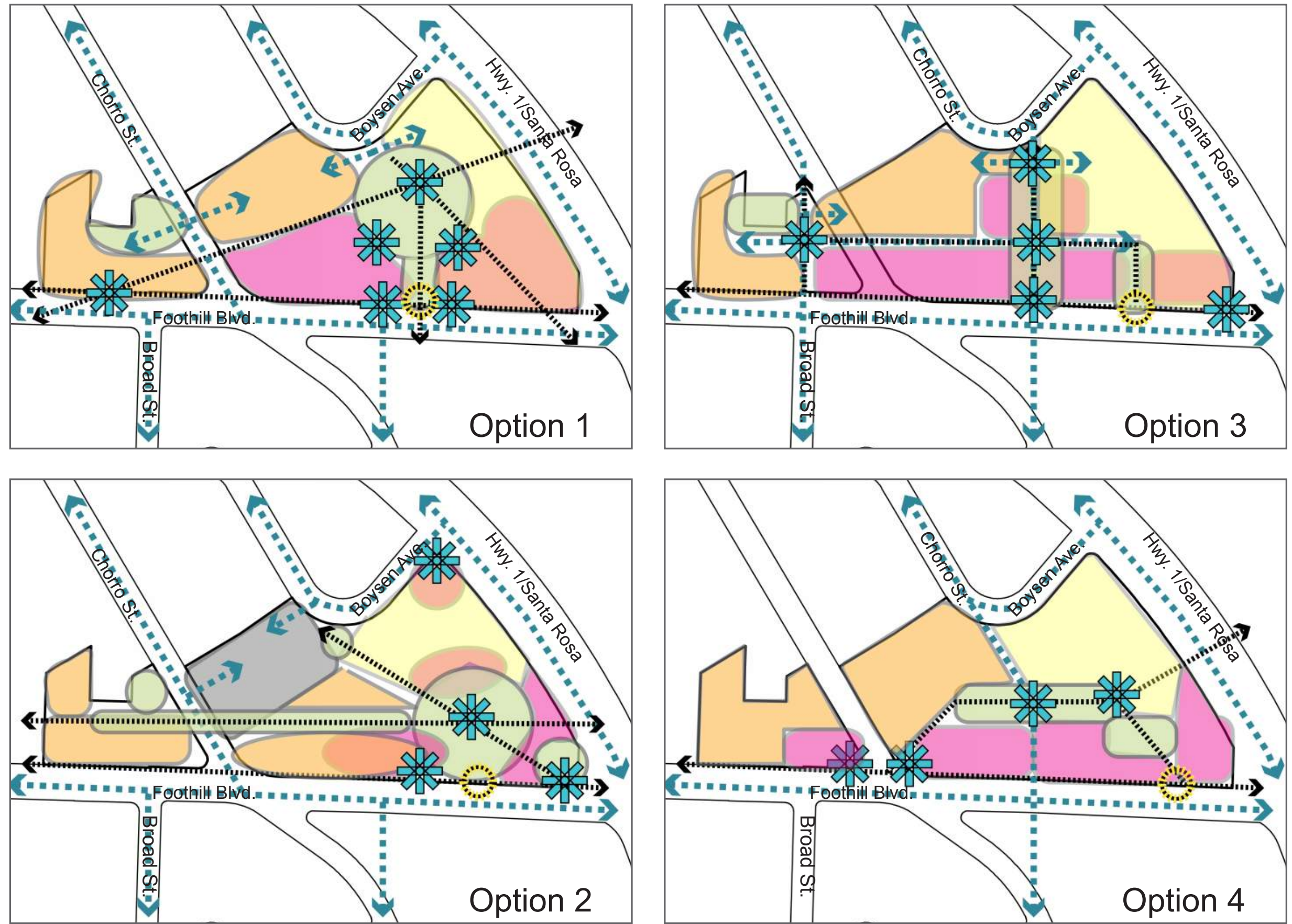

Student Apartments

$\square$ Condominiums $\square$ Retail

$\square$ Parking Structure
Public Space

- - Vehicular Circulation
„.. Pedestrian Circulation $\quad \fallingdotseq$ Transit Hub

Landmarks 
1/Santa Rosa Street is to be heavily landscaped, providing a buffer between student housing and the busy street. Additionally, a pedestrian bridge (seen in Figure 5.3 as callout \#13) is provided from the student housing to the eastern side of Highway 1/Santa Rosa Street for pedestrian safety and accessibility.

The major realignments of Chorro Street, Boysen Avenue, and Broad Street create a greatly improved circulation network and a new public "main street" on the Chorro Street realignment. This public street; renamed "Chorro Street at University Square," and seen in Figure 5.3 as callout \#7, becomes the focal point of the local neighborhood and effectively provides a buffer between the student housing and condominiums. Foothill Boulevard retains its commercial character with ground floor retail fronting all three blocks and rounding onto Chorro Street at University Square. The buildings fronting Foothill Boulevard and Chorro Street at University Square, (seen in Figure 5.3 as callouts \#6 and \#14,) are designed as mixed-use with retail on the ground floor and student housing or condos on the upper floors. Foothill Boulevard also retains the transit hub, which has been enhanced to create a new "transit plaza." The transit plaza is the southern terminus of a main pedestrian axial that connects north to Boysen Avenue. Several other pedestrian paths connect perpendicular to the pedestrian axial, connecting the student housing portion of the Site with Chorro Street at University Square and the Condominiums to the transit plaza and market.

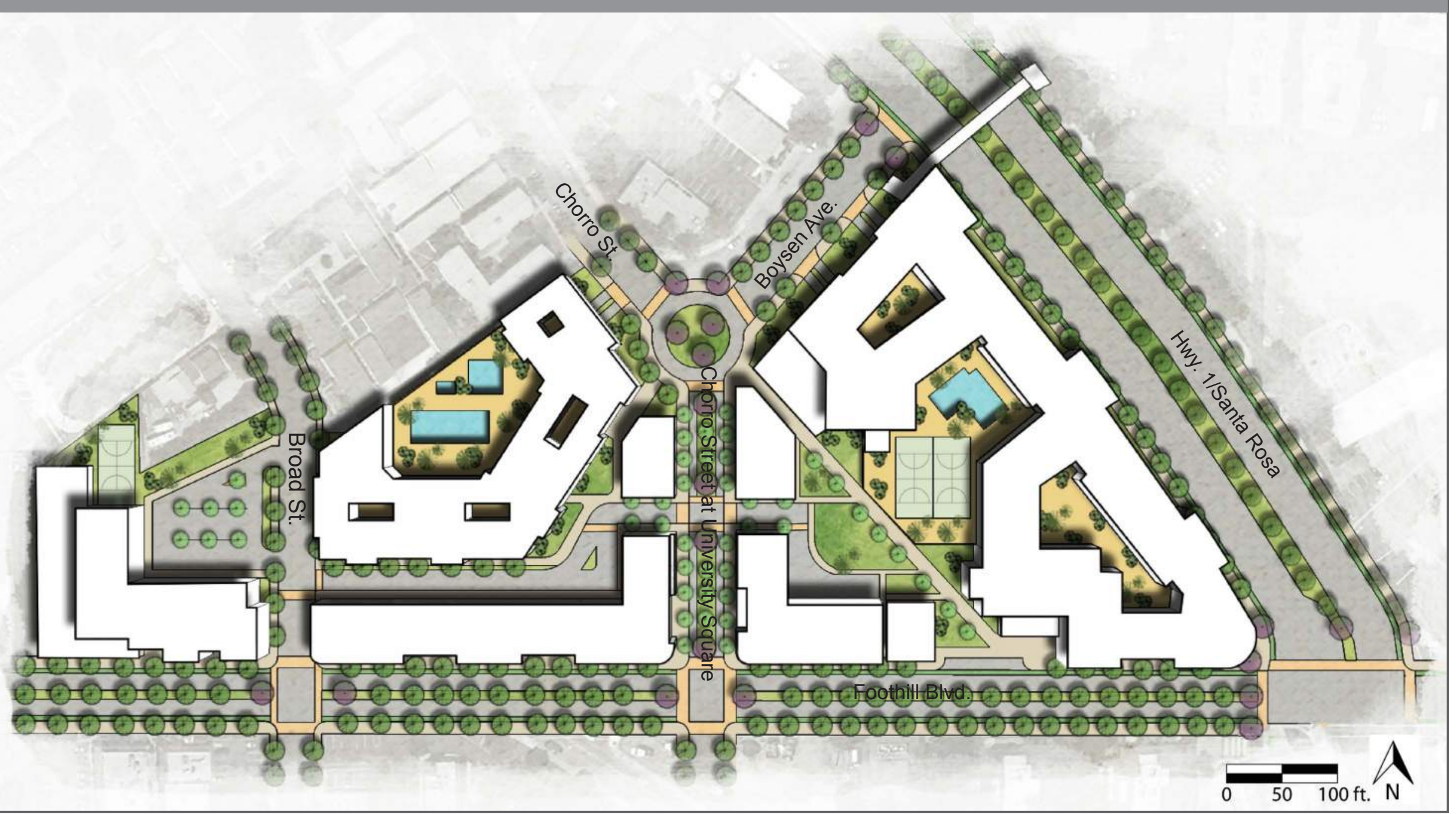




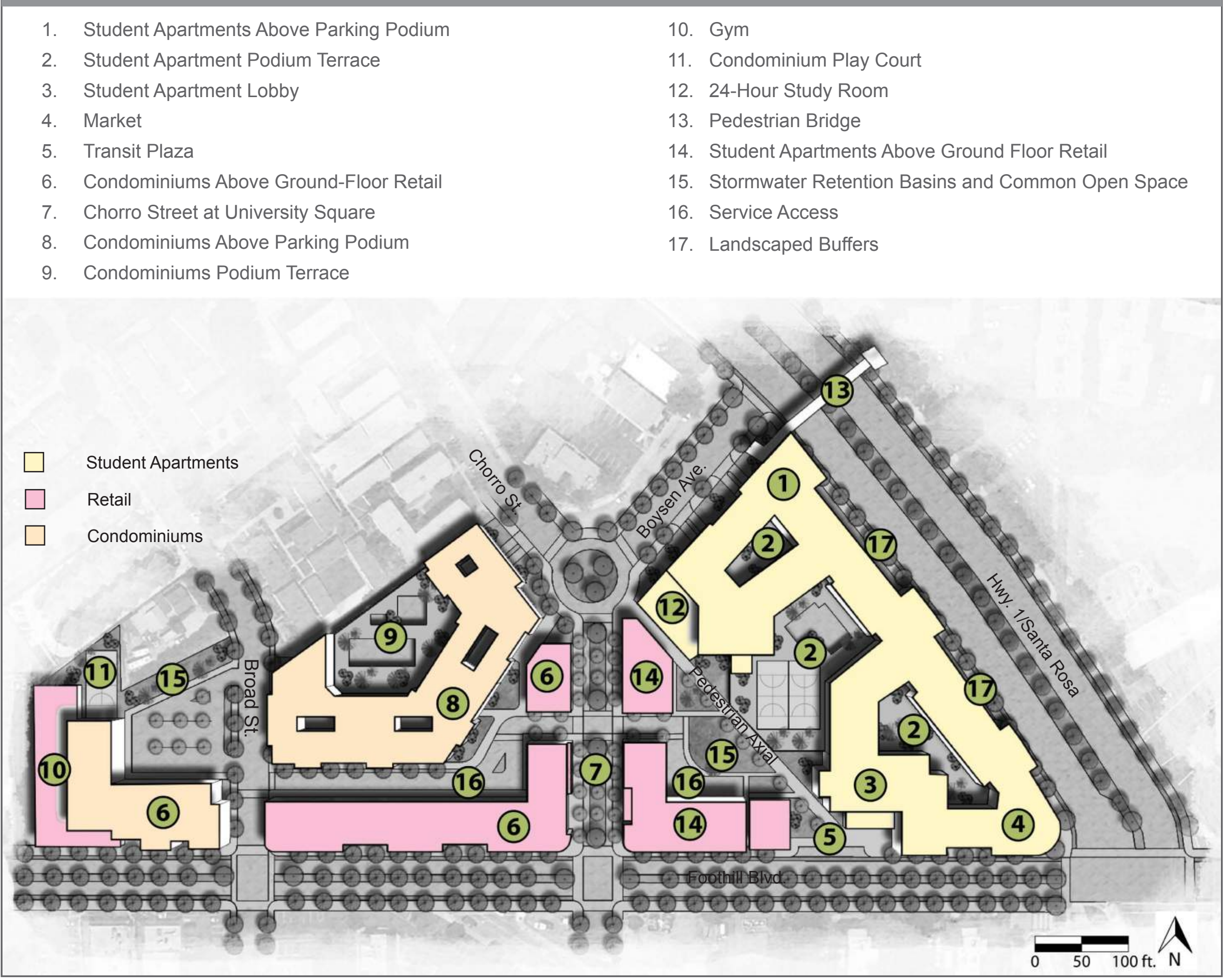


FIGURE 5.4 - Sections Locations Map

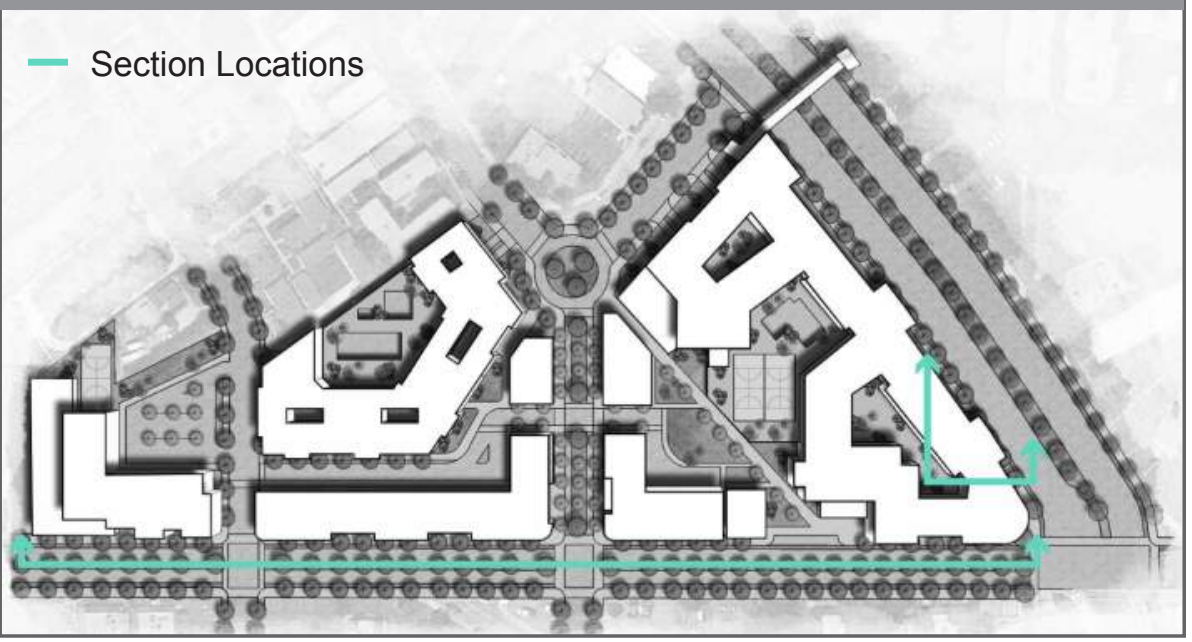

FIGURE 5.5 - Section A: Podium Terrace, Podium Parking, and Market

\section{$\square$ Student Apartments $\square$ Parking}

Market

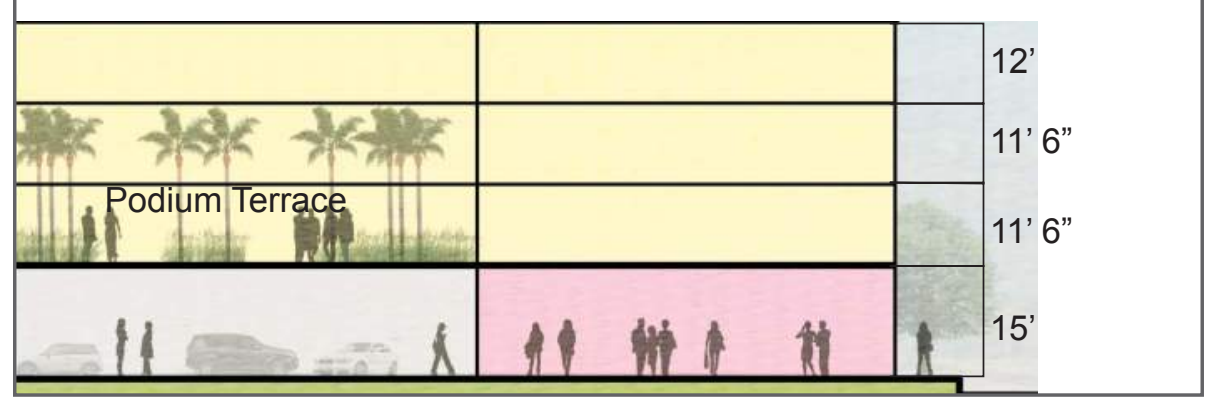

New middle income condominiums provide much needed housing in the City, and are situated on the west side of Chorro Street at University Square. The main condominium building (seen in Figure 5.3 as callout \#8) is envisioned as three stories on top of a podium parking structure that covers the majority of the buildings footprint for a total of 4 stories with a 50 foot building height. The building is oriented towards Bishops Peak for views, privacy, and natural daylighting.

The most western portion of the Site is devoted to a 15,000 square foot gym on the ground floor (seen in Figure 5.3 as callout \#10) with two stories of condominiums above. Surface parking is provided off of Broad Street for both the condominiums and the gym. Stormwater retention basins are included on the western and eastern portion of the Site, these are indicated in Figure 5.3 as callout \#15.

As a central part of the USDP Vision, Chorro Street at University Square, is envisioned as a pedestrian oriented shopping and leisure street. The road is divided by a large median with one way traffic running on either direction on either side. The large median is envisioned as plaza space similar to the one seen at Santana Row in San Jose, California. This space could include outdoor dining, places for people to sit, generous landscaping, and even a water feature such as a fountain. The sidewalks on either side of the street are designed at 12 feet wide to accommodate ample foot traffic, outdoor furniture, and outdoor dining. Some of the retail uses envisioned in this area include some of the existing businesses such as Black Horse Cafe, University Barber, Pita Pit, and Golden 1 Bank. New cafes, restaurants, and retail outlets will also help enliven the streetscape and provide for a greater range of human activity.

FIGURE 5.6a - Section B: Foothill Boulevard

Student Apartments $\square$ Condominiums $\square$ Retail

Chorro St. at University Square

Gym

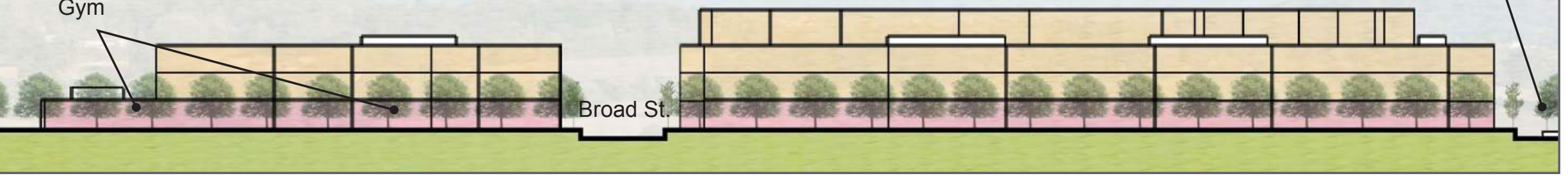




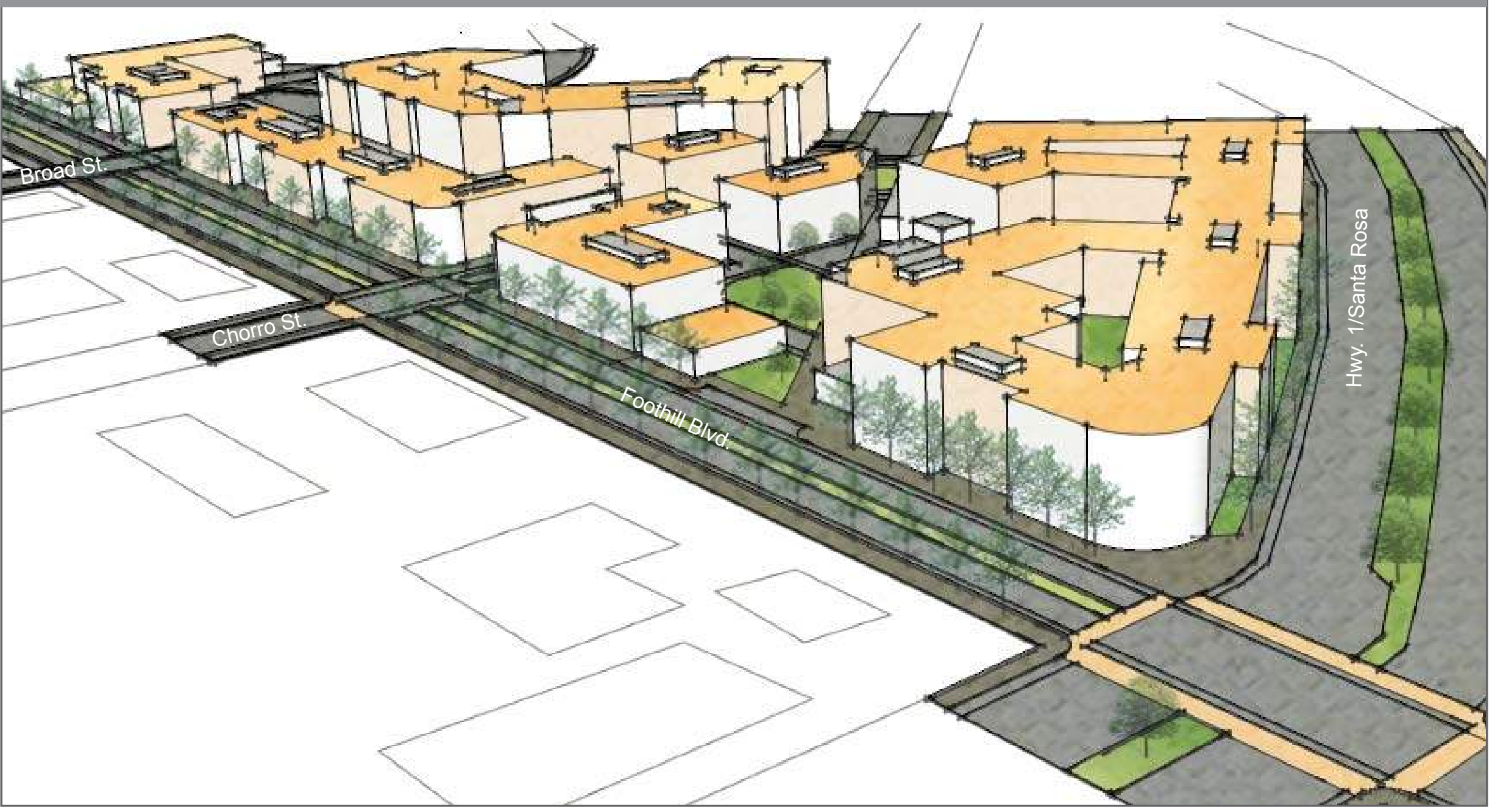

FIGURE 5.6b - Section B: Foothill Boulevard

$\square$ Student Apartments $\square$ Condominiums $\square$ Retail

Chorro St.

at University Square

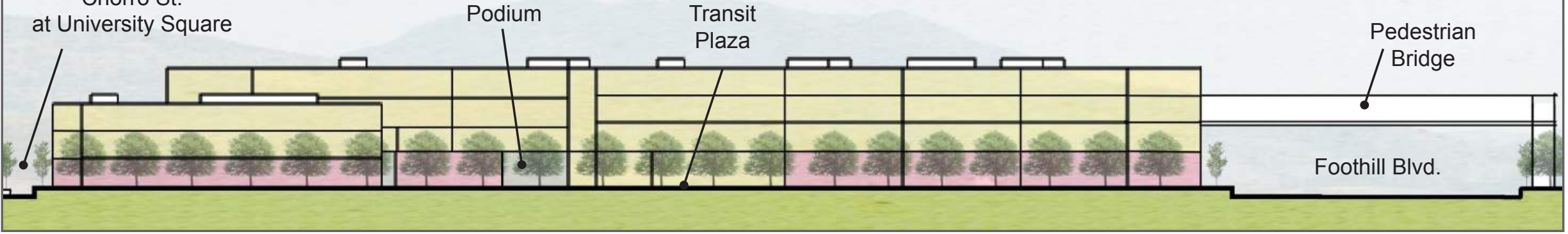


FIGURE 5.8 - Public Spaces Map

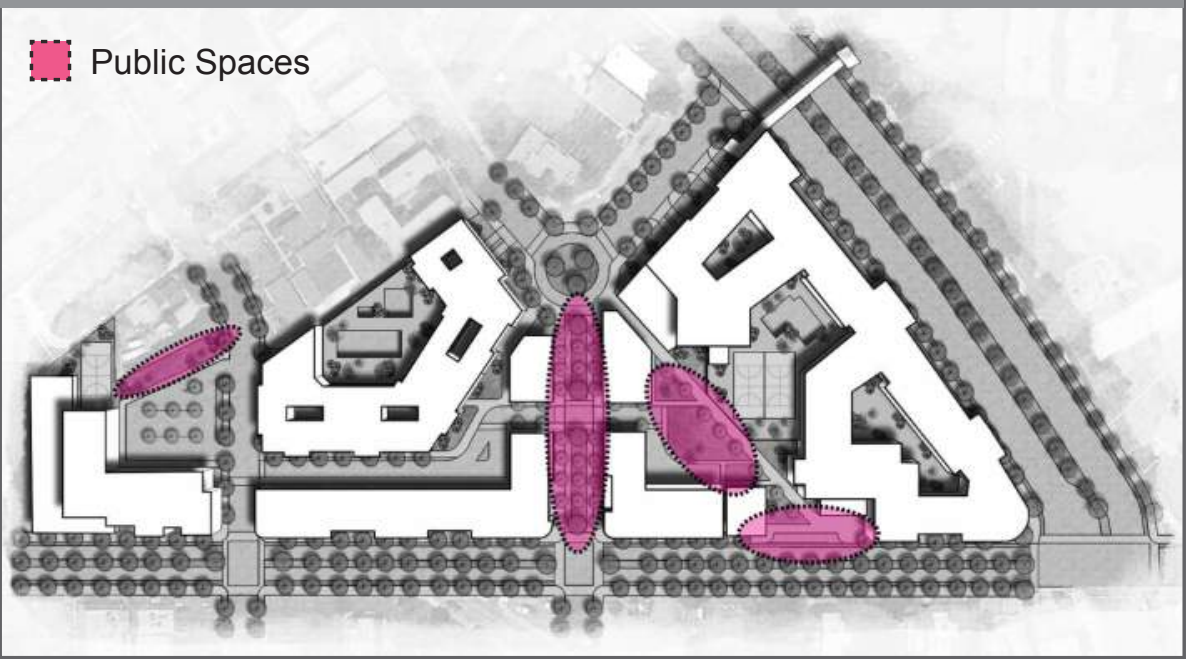

The roundabout at the northern section of the block is seen as a distant focal point, and could include a distinguishing feature such as a fountain or monument sign. Other public spaces are included throughout the Site. Figure 5.8 shows the large public spaces including the transit plaza, Chorro Street at University Square, and the large stormwater retention basins that double as common open space during dry weather.

Both the student housing and the condominiums have "podium terraces" as core features of their design (their locations are shown in Figure 5.9.) The podium terraces are on the second floor of the buildings above parking and provide private open space and amenities for the Site's residents. These spaces are seen as crucial in encouraging prospective buyers and renters to the Site. They should be of the highest possible quality, and include active recreational facilities such as pools, spas, and sports courts, as well as passive

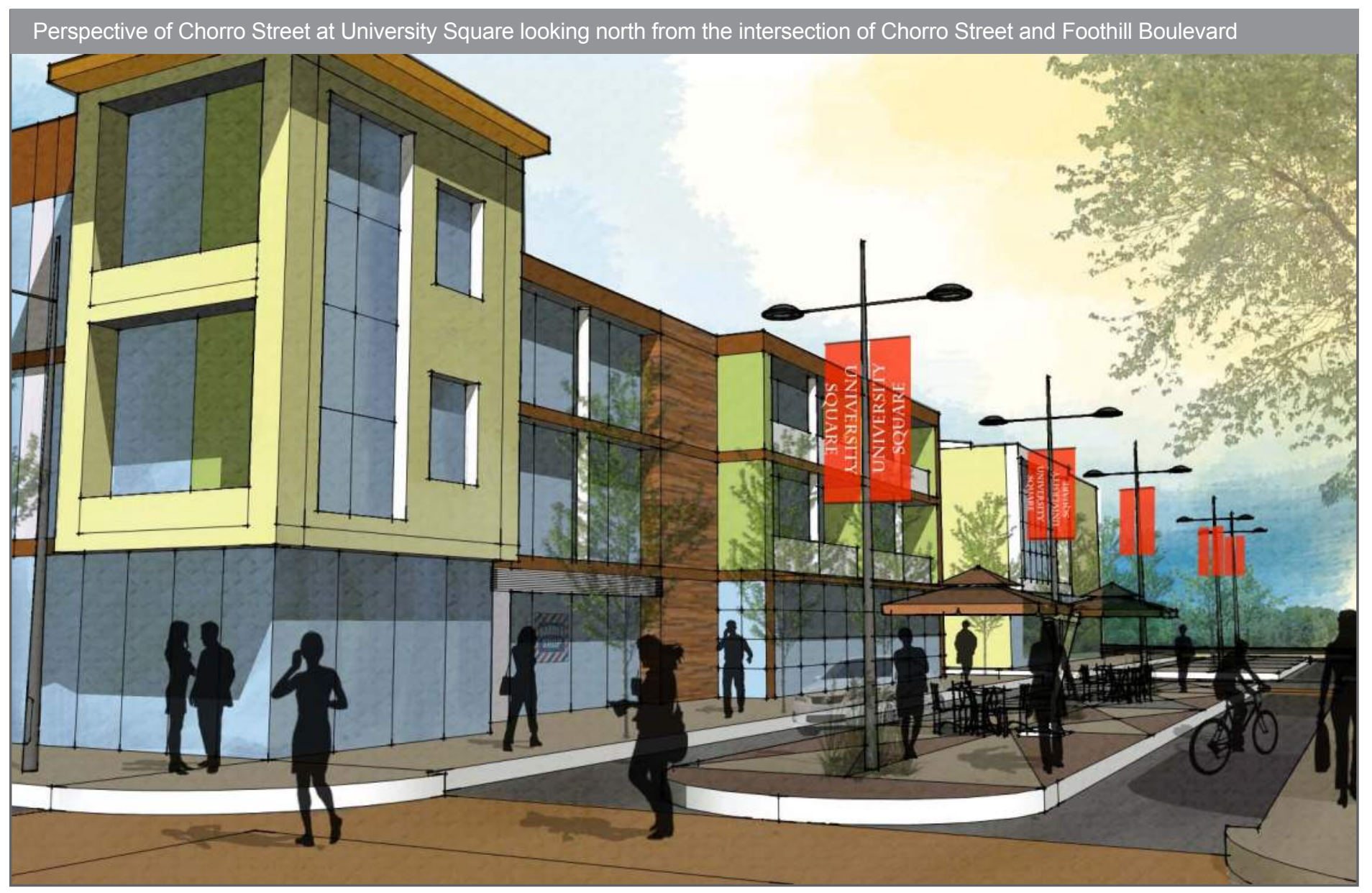
amenities such as outdoor dining areas, lounges, and gardens. The podium terraces should be generously landscaped to provide a sanctuary and feeling of calm. The interplay of materials, hard-surfacing, and landscaping contribute to a holistic environment and sense of serenity. The podium terraces should also serve to separate the public portions of the Site from the private portions of the Site, allowing residents safety and privacy.

The USDP Vision also recognizes the need for back of house for the commercial portions of the Site. A smaller road connects one-way from Broad Street on the west to Chorro Street at University Square on the east, and at a two-way turn-around 
west of Chorro Street at University Square. While these streets are necessary for service and delivery they are designed to not detract from the design. They are not designed with separating walls but instead incorporated into the overall design with sidewalks and landscaping on either side. They could also be designed to incorporate handicapped or short-term parking.

An additional amenity that has been incorporated is a 24-hour study room (seen in Figure 5.3 as callout \#12). The study room provides a quiet room for students. This will also quiet this corner of the site, which is important due to its to the condominiums. The study room should be incorporated into the main building but designed in a distinguishing manner to create a dignified, well lit, and peaceful space.

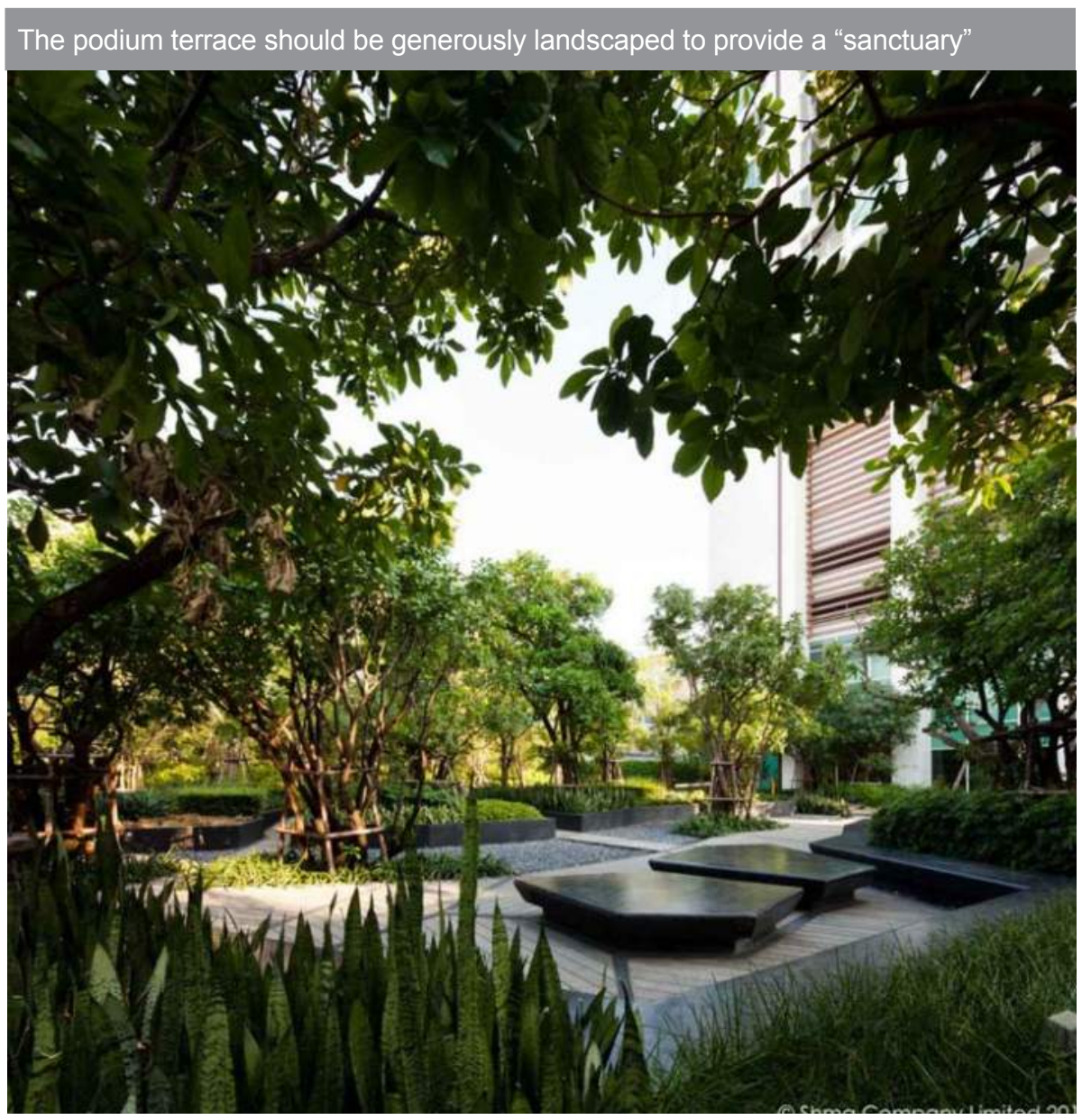

FIGURE 5.9 - Podium Terraces Locations Map
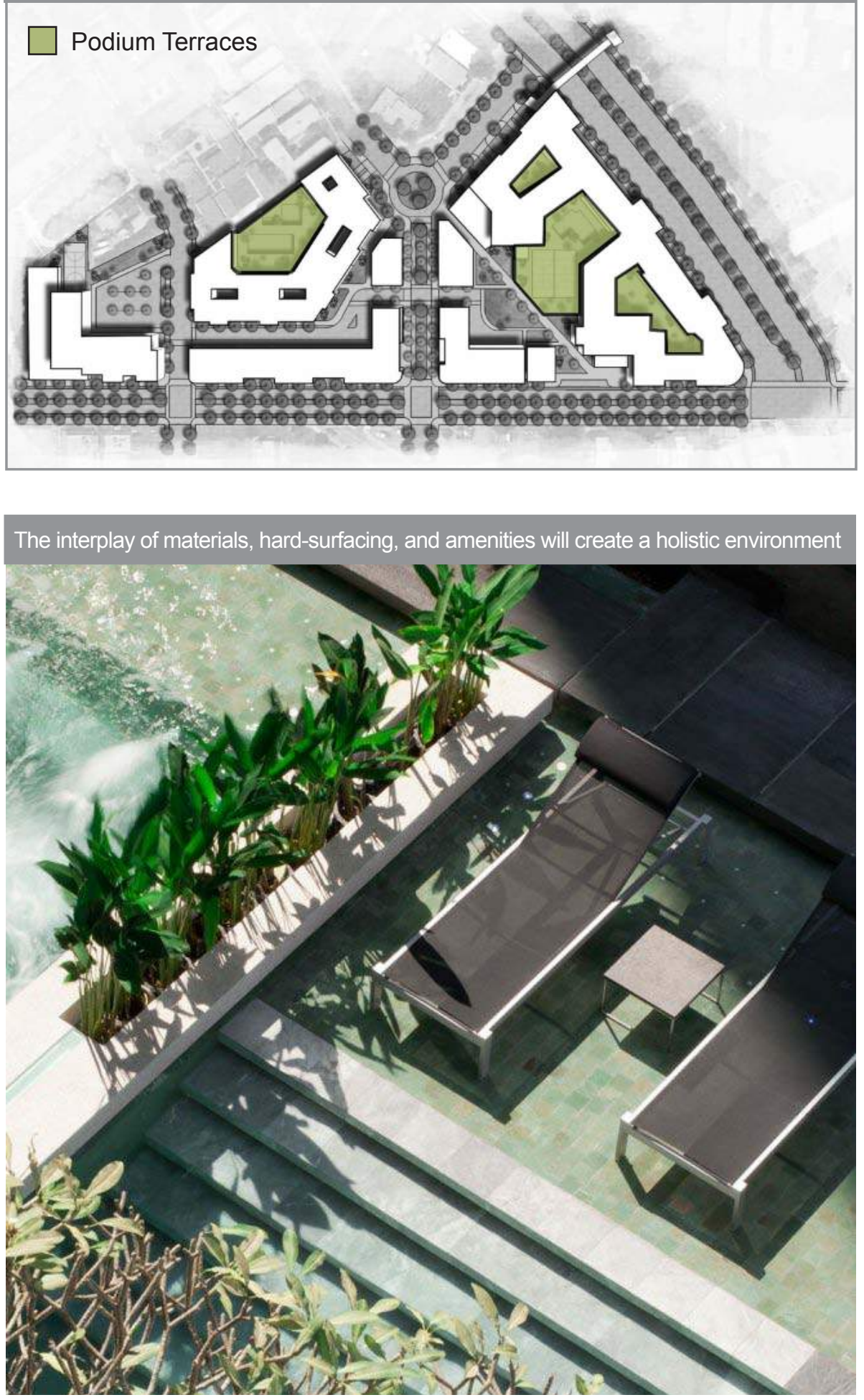
FIGURE 5.10 - Vehicular Circulation and Parking Map

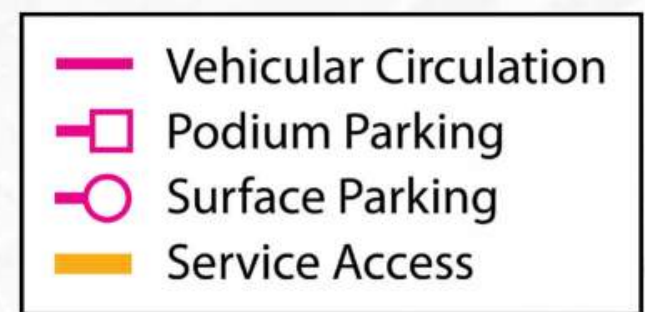
improve safety at this once awkward intersection. Through traffic on Chorro
Street at University Square is not envisioned to be heavy due to the pedestrian orientation of the street, reduced lane widths, and traffic calming measures. The overall parking goal for the USDP Vision is to provide a pedestrian oriented atmosphere that encourages visitors and residents to park once and walk to many destinations. The majority of the parking at University Square will be in the podiums underneath the student housing complex and the condominiums. The podium parking underneath the student housing is split between student residents and retail shoppers. The majority of the podium parking underneath the condominiums is reserved for the residents with only a small amount for retail. Additional retail surface parking is provided off of Broad Street. Figure 5.8 shows the vehicular circulation and parking proposed at University Square. Chorro Street connects to what is now the northern part of Boysen Avenue, becoming Chorro Streets new realignment. The intersection of Boysen Avenue

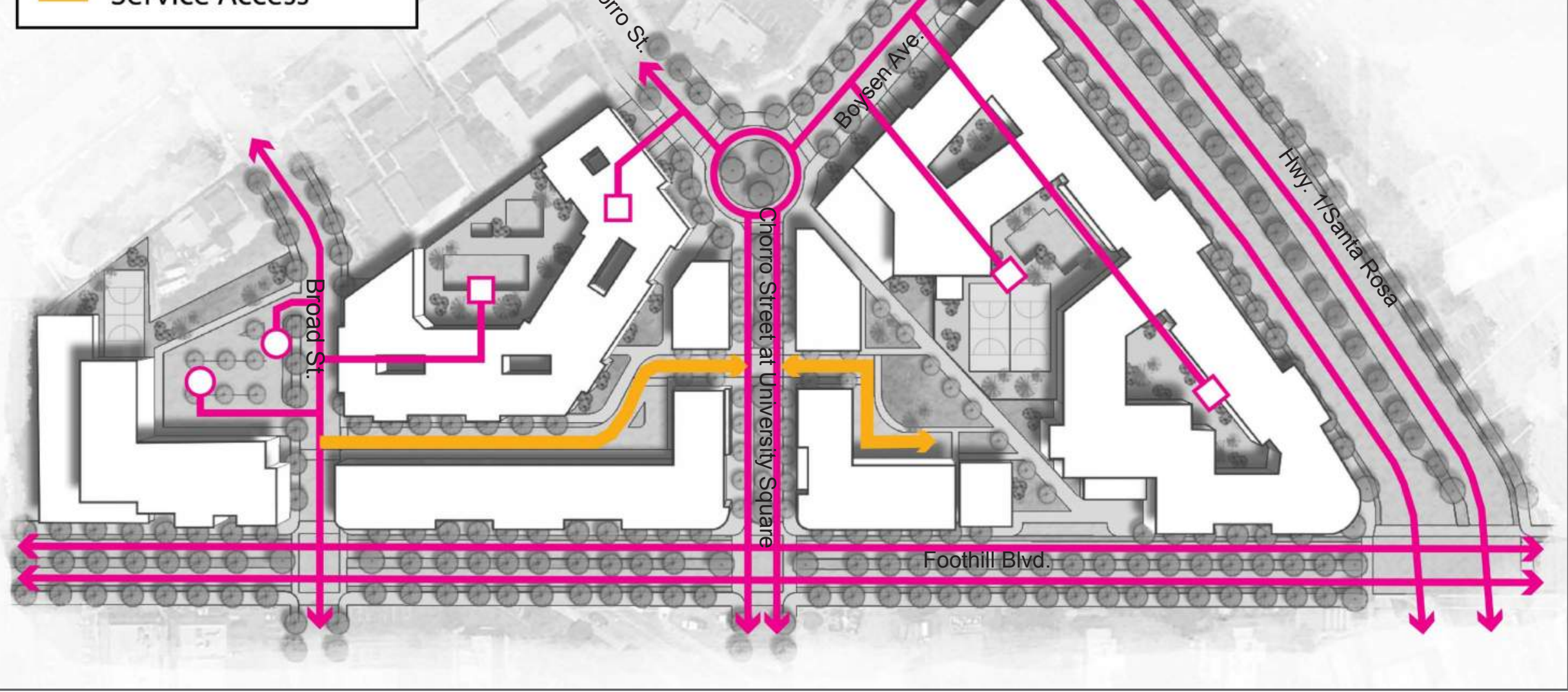




\subsubsection{Transit Circulation}

Figure 3.10 in Section 3 shows that the Site is well served by local transit. Current routes SLO Transit bus routes 1, 4, 5, and 6A all stop at University Square. These routes, in aggregate, provide transit access to the rest of the City, including Downtown and Cal Poly. Additionally, San Luis Obispo County Regional Transit Authority (RTA) route 12 has a stop at Foothill Boulevard and Santa Rosa, connecting the Site by transit to Morro Bay, Cayucos, and Cambria. The USDP Vision aims to capitalize on this transit access, and encourage transit ridership with the creation of a transit plaza on Foothill Boulevard. The plaza should have a dignified design that makes a project focal point.
This focus on transit also helps the project meet its parking reduction goals through compliance with the San Luis Obispo Municipal Code 17.16.060 Parking space requirements: Section E. Automobile Trip Reduction. The transit plaza is a part of overall traffic demand management (TDM) and will reduce single-occupant vehicle travel to and from the site. Figure 5.9 shows the transit circulation and transit plaza proposed at University Square.

FIGURE 5.11 - Transit Circulation Map
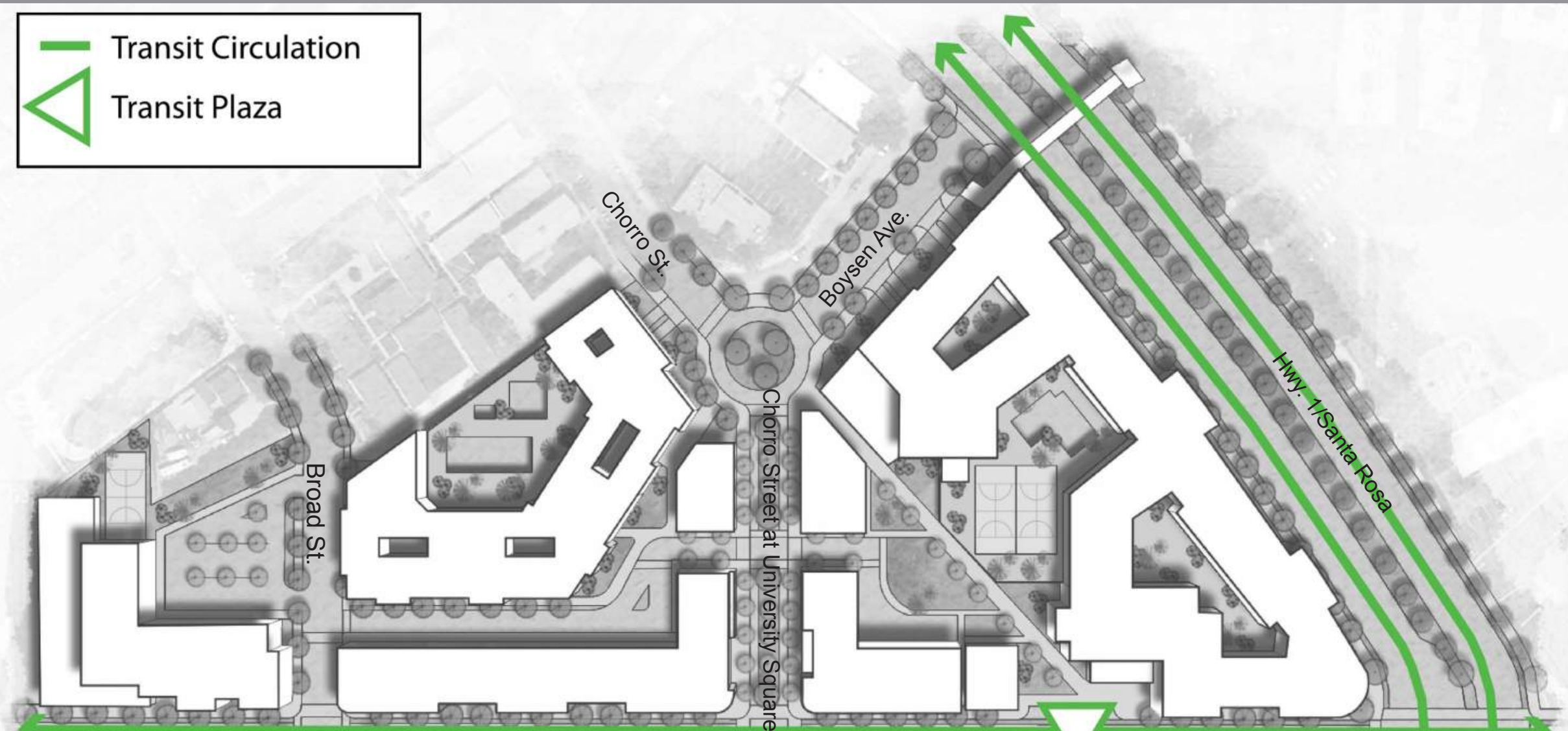
The USDP Vision provide a pedestrian oriented atmosphere that encourages visitors and residents to access shops and home on foot. Streetscape improvements such as new medians on Foothill Boulevard, the median at Chorrro Street at University Square, and the pedestrian bridge over Highway $1 /$ Santa Rosa Street will greatly improve pedestrian visibility and safety.

The pedestrian bridge in particular helps to solve an existing major pedestrian challenge by providing a connection from the student housing to Cal Poly.
Currently part of the street is used by students as a crossing in which they have been seen to play frogger with oncoming traffic. The pedestrian bridge may also be designed to allow for bike crossing. Internal pedestrian paths and sidewalks provide connections between uses, parking, and to the neighboring community. Figure 5.10 shows the pedestrian circulation routes proposed at University Square.

FIGURE 5.12 - Pedestrian Circulation Map

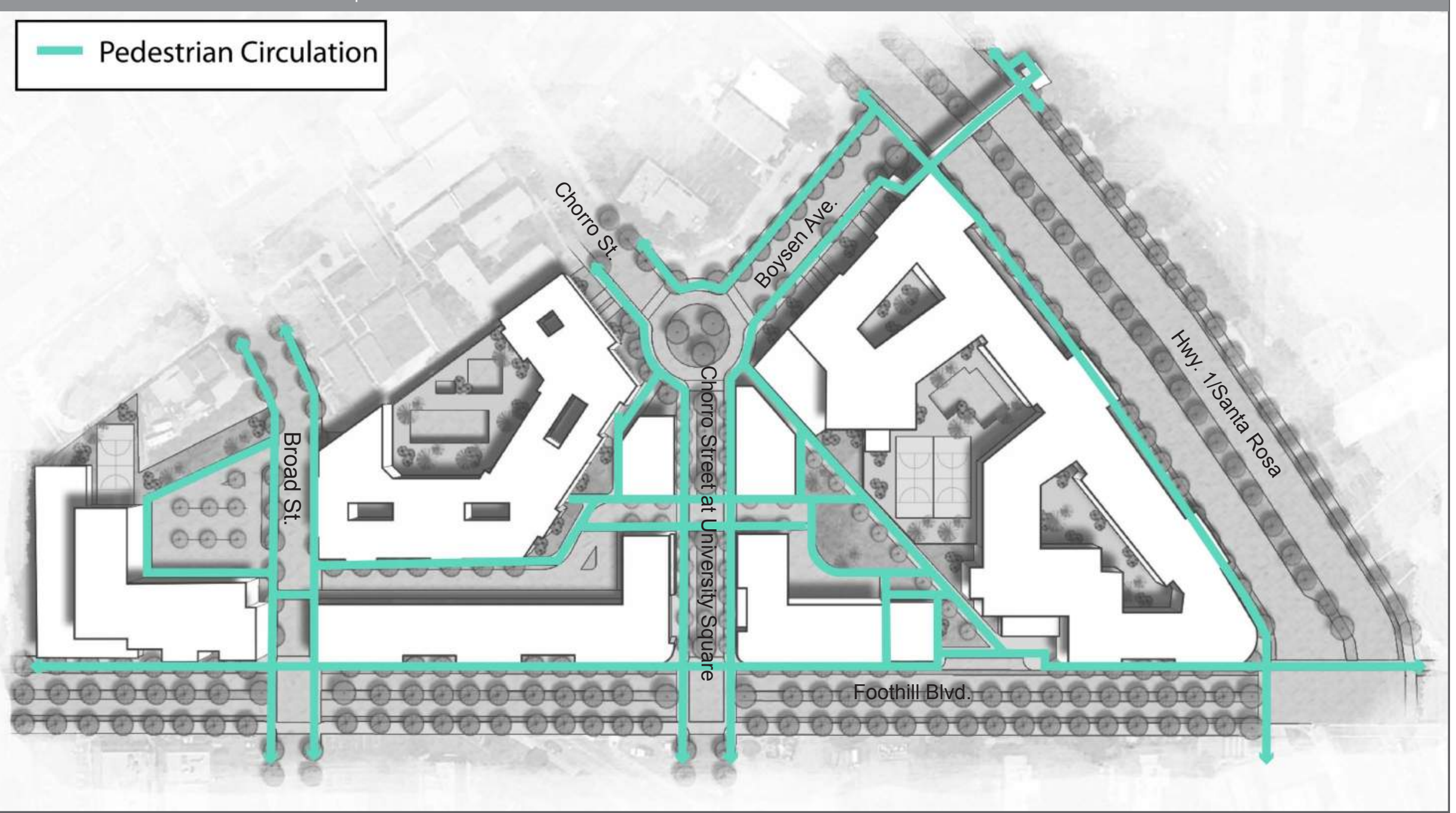


The USDP Vision respects existing efforts by the City of San Luis Obispo to make the City a safe place to bike. Existing bike routes on Highway 1/Santa Rosa and Foothill Boulevard should be enhanced with green painting as is seen in other parts of the City. Internal bike routes focus less on separated bike lanes and bike paths and instead use "chevrons," which are painted directional signage indicating that bicycles have equal access to the right-of-way.

Adequate bike parking should be provided throughout the Site to encourage residents and visitors to bike to and from University Square. Figure 5.11 shows the bike circulation routes proposed at University Square.

FIGURE 5.13 - Bike Circulation Map

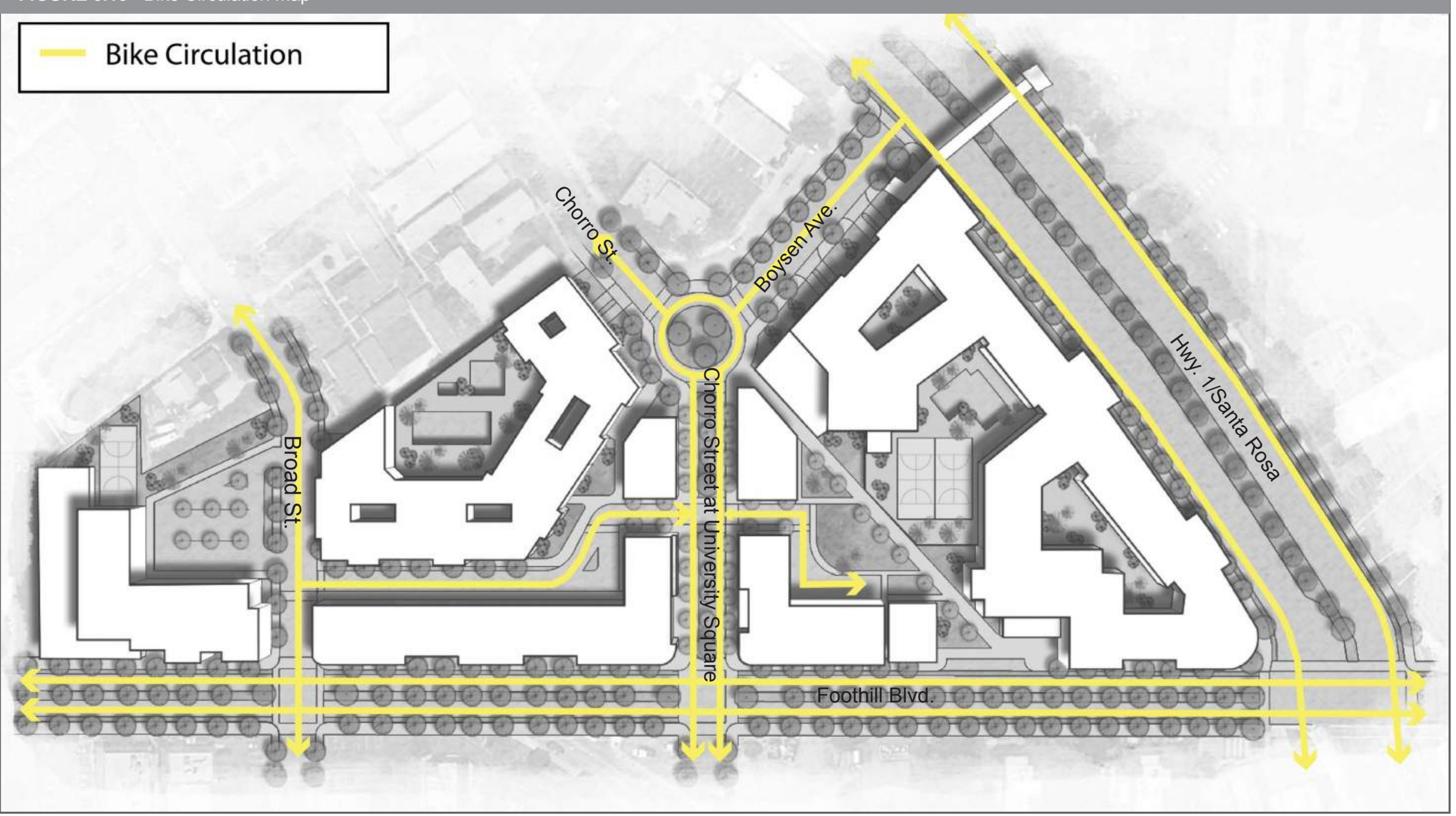




\begin{tabular}{|l|c|c|c|}
\hline Urban Design Principle & Good (2) & Fair (1) & Poor (0) \\
\hline Human Scale & & X & \\
\hline Respect for Pedestrian & X & & \\
\hline Variety in Land Uses & X & & \\
\hline $\begin{array}{l}\text { Variety in Human } \\
\text { Activities }\end{array}$ & X & & \\
\hline $\begin{array}{l}\text { Well Maintained } \\
\text { Buildings and Public } \\
\text { Spaces }\end{array}$ & $\mathrm{X}$ & \\
\hline $\begin{array}{l}\text { Inclusion of Green } \\
\text { Space }\end{array}$ & $\mathrm{X}$ & & \\
\hline $\begin{array}{l}\text { Building Set-backs } \\
\text { Close to the Street }\end{array}$ & $\mathrm{X}$ & & \\
\hline $\begin{array}{l}\text { Unified Building and } \\
\text { Natural Materials }\end{array}$ & $\mathrm{X}$ & & \\
\hline Functionality & $\mathrm{X}$ & & \\
\hline $\begin{array}{l}\text { Connections and } \\
\text { Permeability }\end{array}$ & $\mathrm{X}$ & & \\
\hline
\end{tabular}

The USDP Vision provides an effective solution for achieving a new mixed-use typology at the University Square Site. To make sure that the design is effective, this proposal utilized two qualitative evaluation strategies. The first strategy used the Urban Design Matrix developed in Section 2 of this Proposal. The results, which are displayed in Figure 5.14, show that the University Square Site is an effective urban design project, with 19 out of 20 total points. The project respects the pedestrian, contains a variety of land uses and human activities, and includes green space and buildings with set-backs close to the street. One critique that may be given of the urban design is that the entire project may not be to human scale. The large student apartment building creates a large street wall on Highway $1 /$ Santa Rosa that precludes a pedestrian atmosphere. While this critique is valid, the design was seen as necessary to acheive the density required by the development program. Commercial frontages and front doors on Highway 1/Santa Rosa were also seen as unappealing to business owners due to the high-speed of vehicle traffic and lack of street parking.

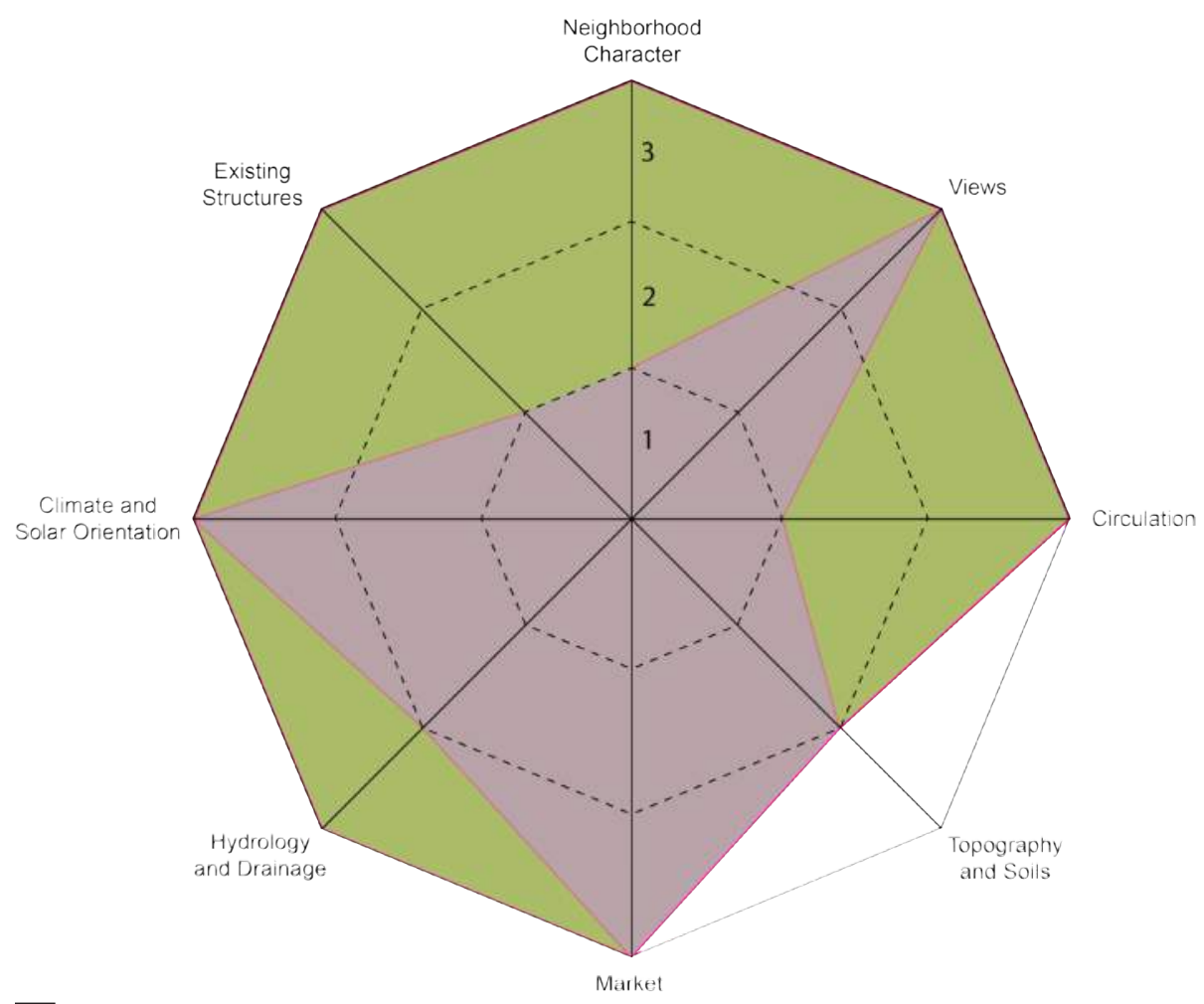

The second strategy used to evaluate the design looked at the original perception matrix created for the Site in Section 3.13. The new perception matrix shown as Figure 5.15: the University Square Perception Matrix, shows outcomes for the site before and after redevelopment. Some factors that would remain the same regardless of the design, including topography and soils and market. Others factors greatly improved with the USDP Vision. The neighborhood character becomes much more pedestrian oriented and distinguishable, circulation becomes coherent, and new quality structures replace the old. Hydrology and drainage is also improved with increased building ground floor heights and stormwater retention basins. The University Square Perception Matrix shows that the USDP Vision improves on current conditions at the Site, and creates an enhanced built environment.

Site Before Redevelopment

Site After Redevelopment 
The USDP Vision proposes a concept that greatly intensifies development of the Site. The new building heights, densities, and land uses that the vision calls for are not allowed under current zoning and land use regulations. In the Land Use and Circulation Element (LUCE) update the City calls the "Foothill Boulevard/Santa Rosa Area" a "Special Planning Area" that favors mixed-use development. Once the new elements are adopted, it is expected that the zoning for the property will change to mixed-use and new more favorable site specific land use regulations will apply. Figure 5.16 shows the proposed parcel re-zoning that would need to occur to achieve the USDP Vision. Ideally, the City of San Luis Obispo would act as a partner during the development process on projects such as infrastructure and circulation improvements. These important partnership opportunities would be especially important for major roadwork such as the Chorro Street and Broad Street realignments and the pedestrian bridge over Highway 1/Santa Rosa Street. Additional partnerships would need to be made with the local residential and business communities, the California Department of Transportation (CalTrans), SLO Transit, and the San Luis Obispo County Regional Transit Authority (RTA) .

The next section contains sustainability design guidelines that help implement the design and vision, and achieve project objective \#5: Sustainability.

\section{FIGURE 5.16 - Proposed Re-Zoning Map}

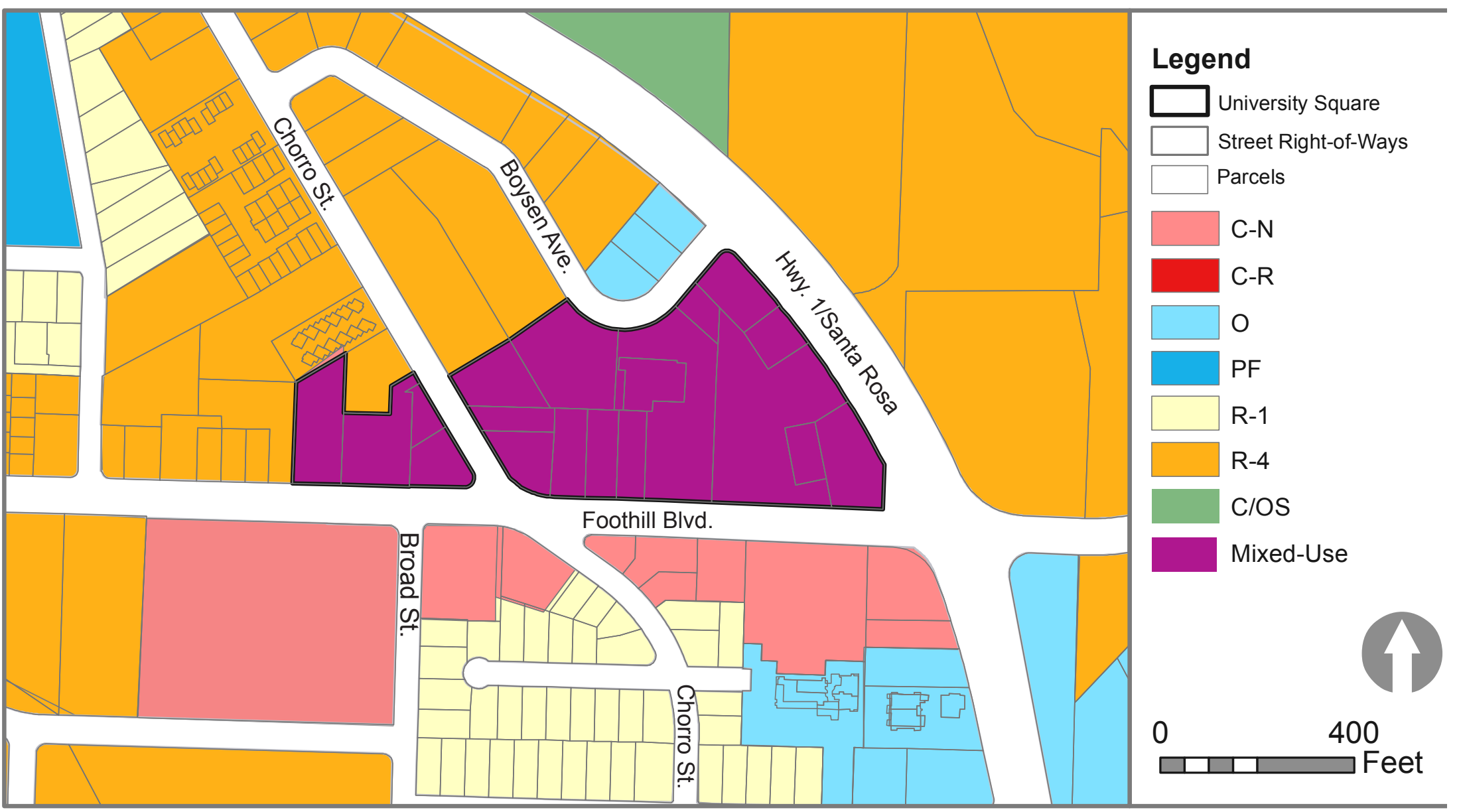




\subsection{SUSTAINABILITY DESIGN GUIDELINES}

Sustainable techniques should be considered during the design, construction, operation, and maintenance of buildings and infrastructure on the University Square Site. The following sustainability design guidelines should be followed to help mitigate negative environmental impacts related to site, building and streetscape development, construction, and maintenance.

\section{The Site}

The efficient layout and organization of the built environment can greatly enhance quality of life and reduce negative environmental impacts.

\section{A. Stormwater Management}

Stormwater management techniques that mimic natural hydrologic conditions can help reduce sheet flow and the velocity of stormwater, and prevent soil erosion and damage.

i) The project site should be designed to maintain natural stormwater flows by promoting infiltration.

ii) Impervious surfaces should be minimized in open space areas.

iii) Site drainage should be designed to integrate a decentralized system that distributes stormwater across the Slte.

\section{B. Bicycle Parking}

Bicycle parking should be provided where practical to encourage the use of this environmentally-friendly mode of transportation.

i) Bicycle parking should be placed in areas where they will be most used such as in parking areas or near building entrances.
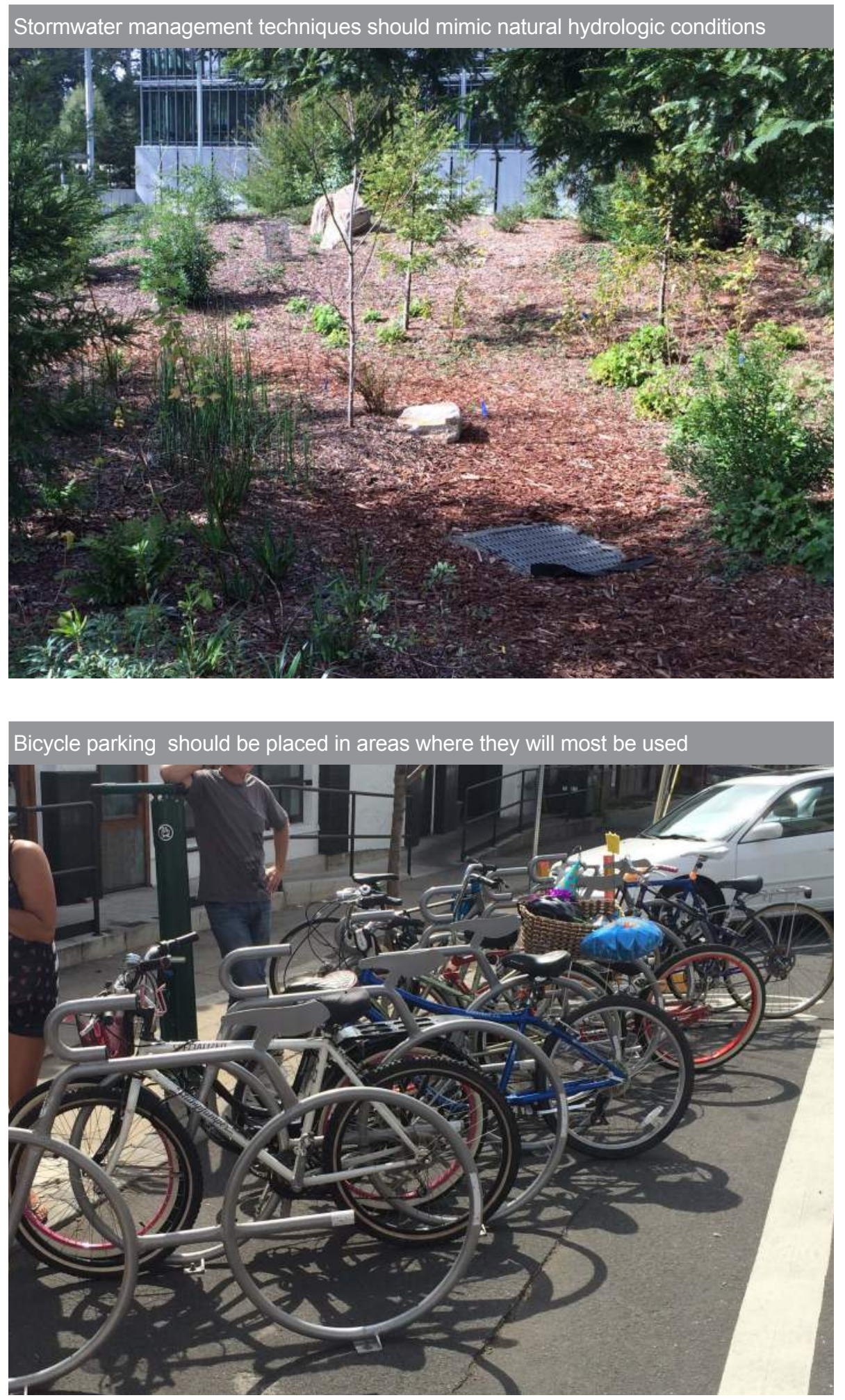


\section{Electric Vehicle Parking}

Electric vehicles (EVs) emit no tailpipe pollutants, and are more efficient at converting electrical energy from the grid to power at the wheels than conventional gasoline vehicles with energy stored in gasoline to power at the wheels.

i) Appropriate parking that allows for EV recharging should be provided to encourage the use of EVs.

\section{Sustainable Landscaping}

Drought tolerant landscaping that respects the local climate, soil, and hydrology is encouraged.

i) Plant selection should be based on San Luis Obispo's climate and environment, as well as site characteristics such as exposure, light intensity, soils analysis, site drainage, and irrigation.

ii) California native species are preferred for natural landscapes.

\section{Buildings}

Building design can reduce environmental impacts related to an individual building's operation. Leadership in Energy and Environmental Design (LEED) is a nationally recognized third-party verification system that provides strategies for designing and developing sustainable buildings. The following design guidelines include LEED recommended practices that should be considered during the design of new buildings at the University Square Site.

\section{E. Solar Orientation}

Building should be designed to take advantage of solar orientation so that windows, walls, and floors are built to collect, store, and distribute solar heat efficiently. gain; this allows the facades to let light in, reduce glare, and reduce overheating to the building interior.

ii) Architectural elements such as skylights and high-performance glazing should also be used to take advantage of, or diffuse, solar energy.

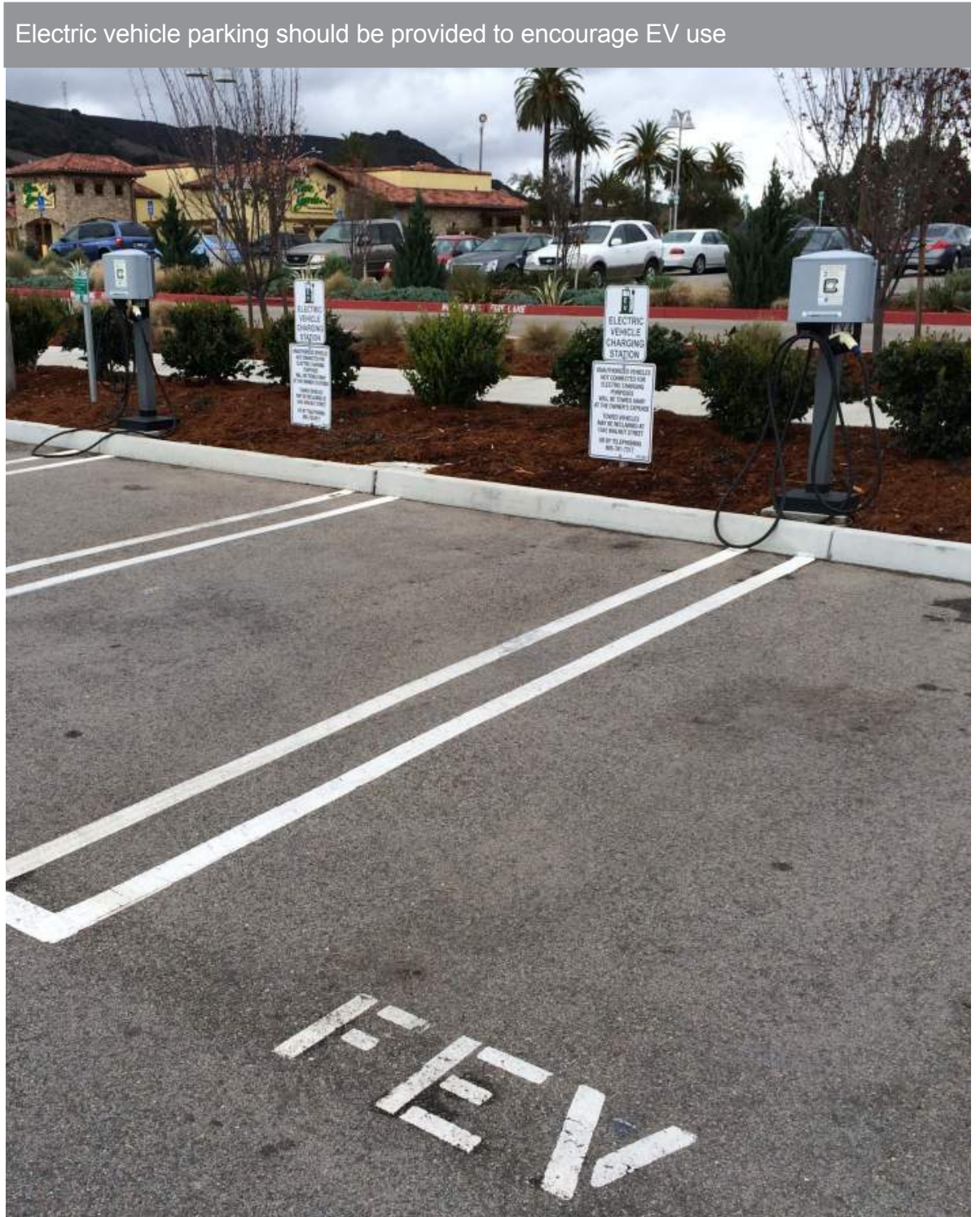




\section{F. Building Materials}

Building materials that minimize negative environmental impacts and resource depletion can deliver attractive alternatives to traditional materials and increase a buildings overall sustainability.

i) Recycled and other environmentally-friendly building materials are encouraged.

ii) Materials that are locally obtained, rapidly renewable, or salvaged from de-constructed buildings are encouraged.

iii) Materials that are perpetually circulated in a closed loop system from manufacture, to installation, to reclamation are encouraged such as bamboo.

\section{G. Energy Efficient Installations}

After transportation, energy generation remains the second largest contributor to global greenhouse gas emissions (EPA.gov). Energy efficient fixtures that help to reduce a building's contribution to greenhouse gas emissions and resource depletion are encouraged.

i) Energy efficient installations that include high-efficiency insulation, low emission and insulating glass, and complete thermal enclosure systems are encouraged.

ii) The use of energy efficient appliances are encouraged, such as Energy Star qualified products which use less energy than traditional appliances. Energy efficient installations and appliances also provide the additional benefit of lowering a building's utility bill.

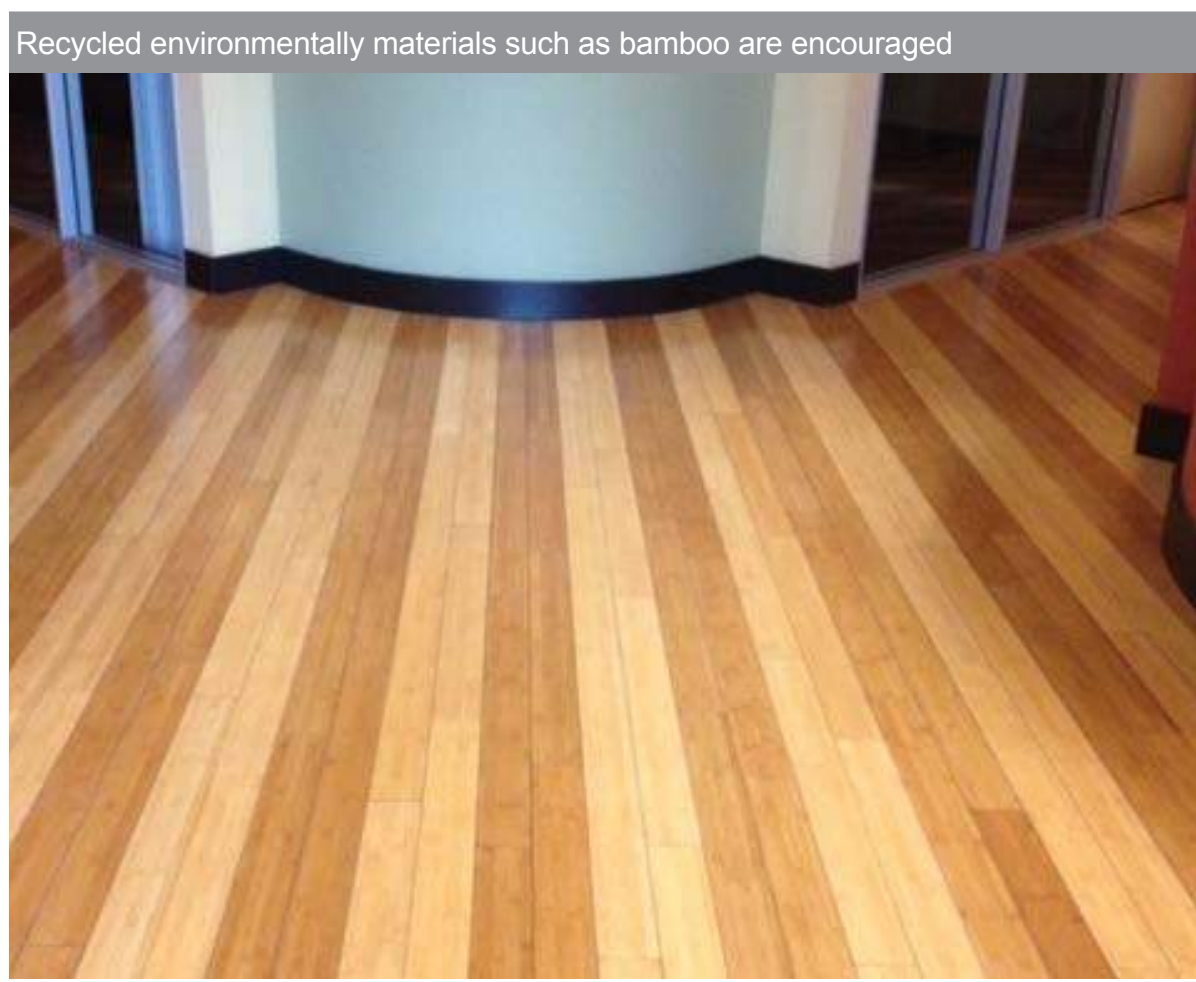

Green roofs can reduce surface temperature and heat transfer to the building

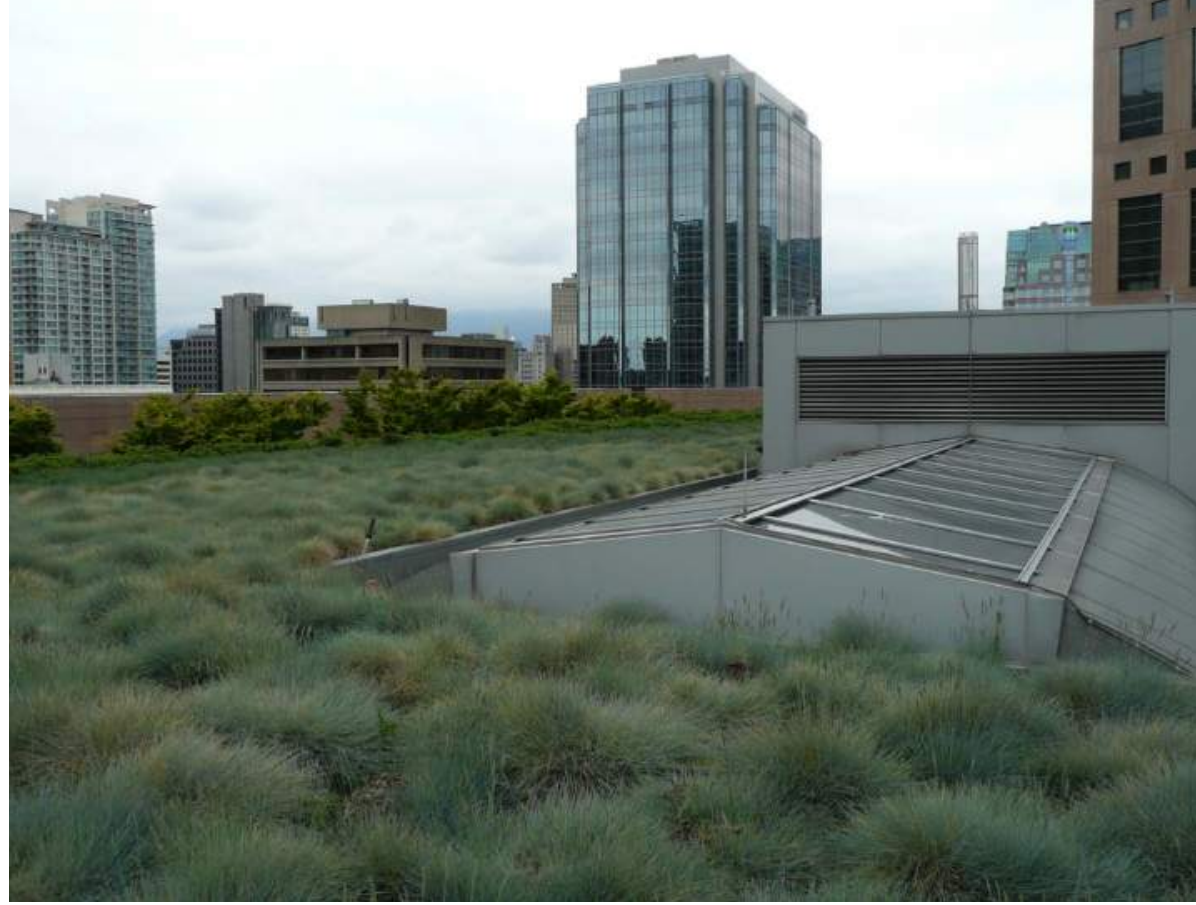


Automatic sensors on plumbing fixtures can decrease overall water consumption
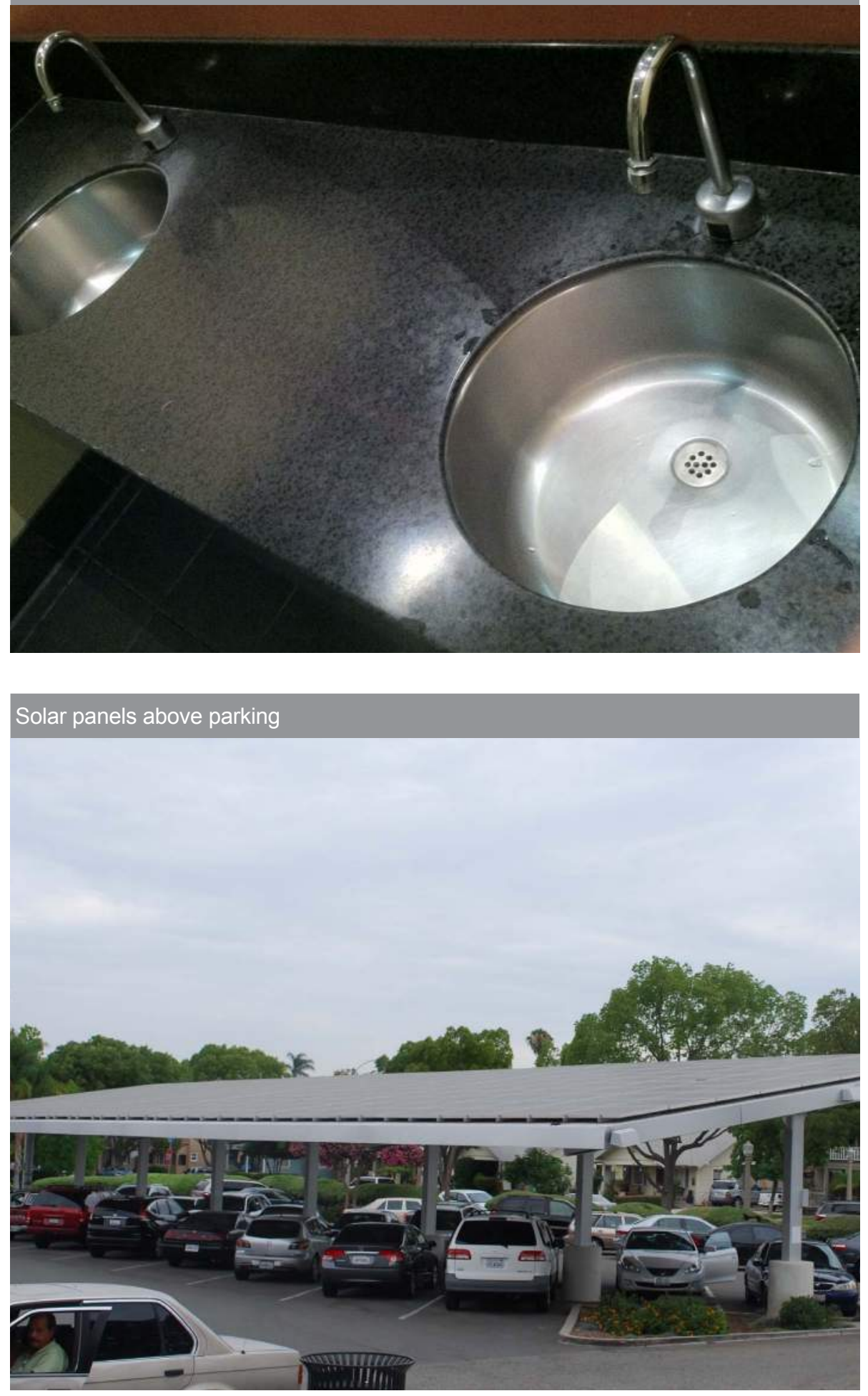

\section{H. Water Efficient Installations}

New water efficient plumbing fixtures and technologies have greatly improved water conservation efforts.

i) Products including automatic plumbing sensors and controls, flow restrictors, low flush and dual flush toilets, and waterless and low flow urinals are encouraged in the design, construction, and retrofit of existing buildings.

ii) The use of non-potable water (grey water) that is captured from hand sinks, showers, and baths is encouraged for use on project landscaping.

\section{Cool Roofs and Green Roofs}

Both cool roofs and green roofs achieve a high level of solar reflectivity which helps in reducing the urban heat island effect and decreases a building's overall energy usage. Cool roofs are roofs consisting of materials that effectively reflect solar energy from the roofs surface, reducing roof surface temperature and the resulting heat transferred to the building below. This helps to reduce energy costs, improve occupant comfort, decrease maintenance costs, and increase the roof's life expectancy.

Green roofs serve the same purpose but are also partially or completely covered with vegetation. A green roof protects the roof membrane from climatic extremes and physical abuse, thereby greatly increasing the life expectancy of the roof and significantly reducing heating and cooling costs.

i) Both cool roofs and green roofs should be considered on buildings.

\section{J. Solar Panels}

Solar panels make use of the sun's energy by harvesting sunlight and actively converting it to electricity. Unlike non-renewable energy sources, solar power does not pollute air and water. It replaces energy generated from facilities powered by coal, natural gas, and other non-renewable fuels with clean energy.

i) Solar panels are encouraged on rooftops and parking structures where they do not obstruct or detract from views. 
Sustainable streetscape techniques improve the aesthetic character of streets while providing many environmental benefits. The following techniques should be included when upgrading existing public rights-of-way on or near the Site.

\section{K. Permeable Paving}

Permeable paving typically refers to pavers, porous concrete, or in some cases, a pathway material such as decomposed granite. These materials can be effectively used for stormwater infiltration and reducing excessive run-off.

i) Streets should be designed to maintain natural stormwater flows by promoting infiltration.

ii) Impervious surfaces should be minimized. Permeable paving should be considered on all street surfaces and surface parking areas.

\section{Bioswales}

Acting as a functional stormwater management system, bioswales redesign traditional curbs and gutters to redirect stormwater into planter strips rather than capturing runoff in pipes and diverting it to a remote location. This helps to filter stormwater runoff into the ground basin which supports aquifer recharge and improves local water quality by emulating natural hydrologic conditions.

i) Bioswales are encouraged for stormwater management.

\section{Street Trees and Vegetation}

Street trees and vegetation absorb heat, nitrogen dioxide $\left(\mathrm{NO}_{2}\right)$, nitrogen oxide (NO), and sulfur dioxide $\left(\mathrm{SO}_{2}\right)$ emissions, while releasing oxygen $\left(\mathrm{O}_{2}\right)$.

i) New street trees and vegetation should be planted during the upgrade of existing rights-of-way and in common open space areas.
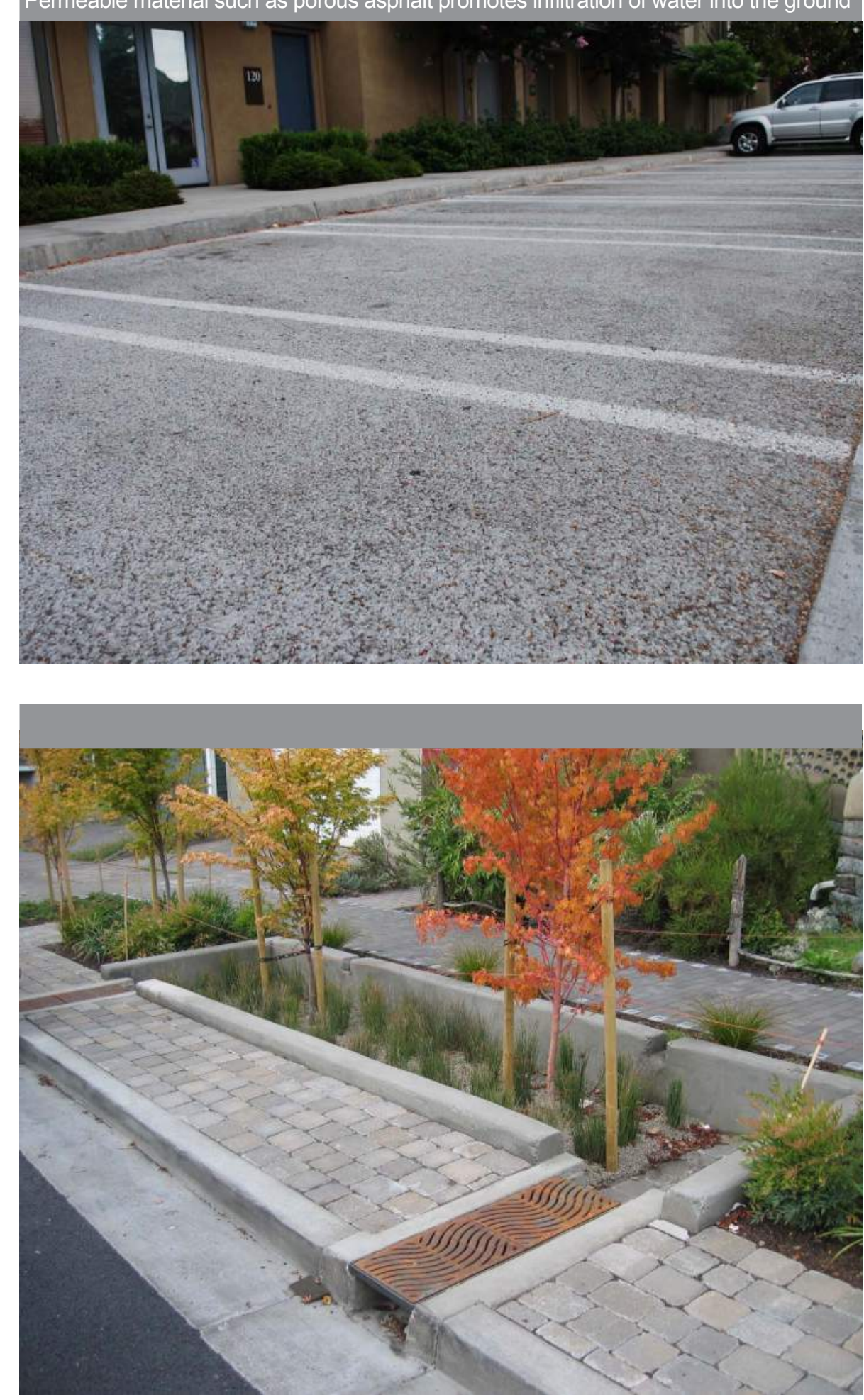
THIS PAGE INTENTIONALLY LEFT BLANK 
FINANCING

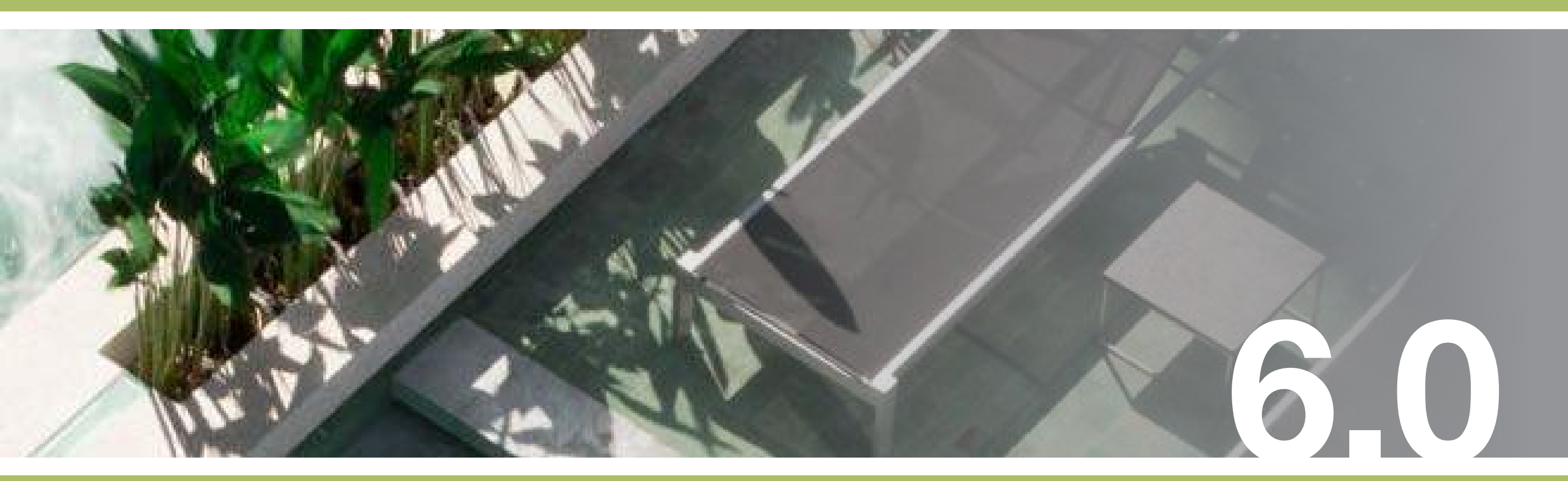


THIS PAGE INTENTIONALLY LEFT BLANK 


\subsection{ASSUMPTIONS}

One of the project objectives is to achieve a financially feasible design and development solution for the University Square Site. This section seeks to achieve this goal with a preliminary assessment of project construction costs and financial performance. However, this is only an early take on the project, and additional analysis would be needed prior to implementation of the project. Underlying the construction costs, cash-flow analysis, and project time line are the following assumptions:

1. Development will take place over a two-year period.

2. Cal Poly, in having an interest in providing more student-housing will be the construction loan provider ( $6.25 \%$ interest).

3. Student housing will rent at $95 \%$ occupancy for 9-months of the year.

4. All condominium sales will occur within the first year of completion.

5. All retail sales will occur within the first year of completion.

\subsection{CONSTRUCTION COST ESTIMATES}

Table 6.1 shows construction costs of student apartments, condominiums, retail, parking, and offsites and infrastructure. Although construction costs for the podium parking are substantial, the cost is significantly reduced through combining the podiums structure with the structure of attached buildings. Table 6.2 shows permits and fee estimates. These estimates make three assumptions:

a) Impact fees are reduced by approximately $15 \%$ for pre-existing uses on the Site.

b) Impact fees would be reduced by $25 \%$ for the student- housing portion of the project, based on the 9-month occupancy of units.

c) Traffic Impact Fees are further reduced by the projects Traffic Demand Management (TDM) strategies, including increasing access to transit, and bicycle and pedestrian infrastructure

Section 3.4 discussed ownership of the Site. The Site's 8.2 acres is currently owned by five different parcel owners: NKT Commercial, BJ Steiner, City of San Luis Obispo, Polin Family Trust, and Estes Edna. For the purposes of
TABLE 6.2 - Permits and Fees Estimate

\begin{tabular}{|l|cr|}
\hline Permits and Fees & \multicolumn{2}{|c|}{ Project Total } \\
\hline Tentative Subdivision Map & $\$$ & $30,000.00$ \\
\hline ARC & $\$$ & $3,000.00$ \\
\hline DFG & $\$$ & $3,000.00$ \\
\hline CEQA & $\$$ & $15,000.00$ \\
\hline Building Permits & $\$$ & $120,000.00$ \\
\hline Sewer Impact Fee (a) & $\$$ & $221,850.00$ \\
\hline Sewer Impact Fee (a) Student Housing (b) & $\$$ & $349,413.75$ \\
\hline Water Impact Fee (a) & $\$$ & $641,070.00$ \\
\hline Water Impact Fee (a) Student Housing (b) & $\$$ & $1,009,685.25$ \\
\hline Traffic Impact Fee (a)(c) & $\$$ & $491,194.09$ \\
\hline Traffic Impact Fee (a)(c) Student Housing (b) & $\$$ & $417,690.00$ \\
\hline Affordable Housing & $\$$ & $1,128,683.98$ \\
\hline Total & $\mathbf{\$}$ & $\mathbf{4 , 4 3 0 , 5 8 7 . 0 7}$ \\
\hline
\end{tabular}

a) Reduced by $15 \%$ for pre-existing uses

b) Based on 9-month occupancy

c) Reduced by project Traffic Demand Management (TDM) 


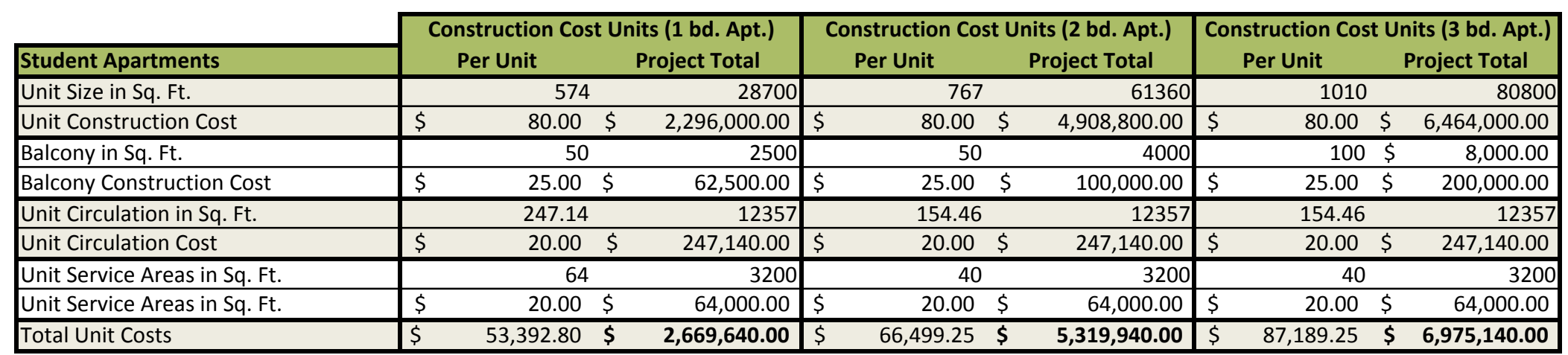

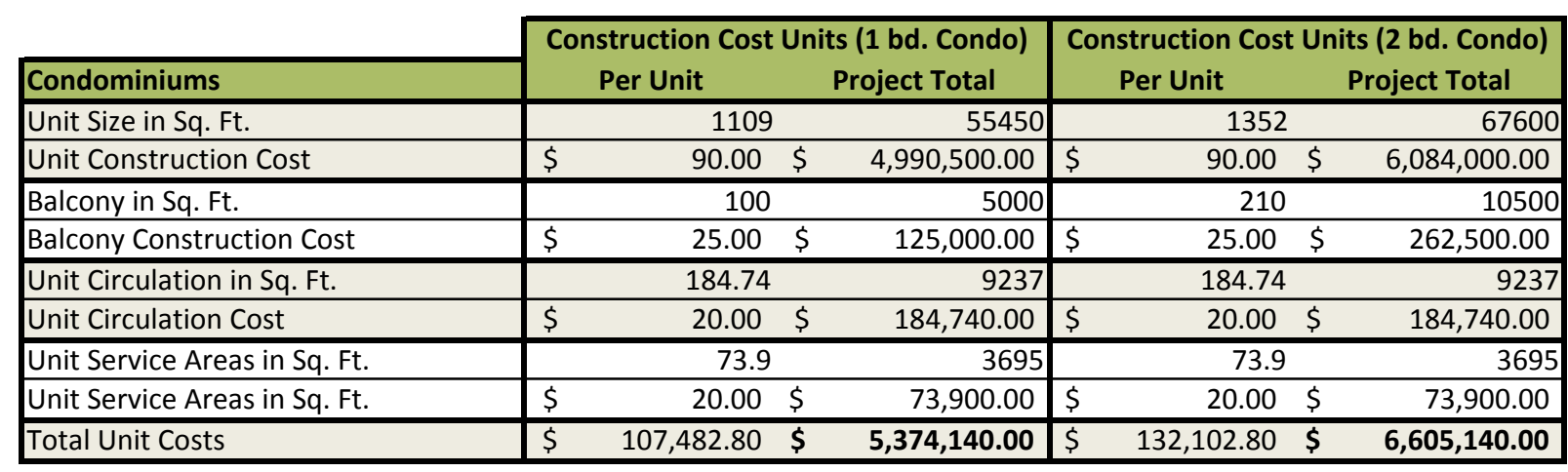

\begin{tabular}{|c|c|c|}
\hline \multirow[b]{2}{*}{ Retail } & \multicolumn{2}{|c|}{ Construction Cost Retail } \\
\hline & sq. ft. & Cost \\
\hline Total Cost & $67000 \$$ & $6,030,000.00$ \\
\hline Total Service Area Cost & $10050 \$$ & $201,000.00$ \\
\hline Construction Cost & $\$$ & $6,231,000.00$ \\
\hline
\end{tabular}

\begin{tabular}{|c|c|c|c|c|}
\hline & \multicolumn{4}{|c|}{ Construction Cost Parking } \\
\hline Parking & & r space & & roject Total \\
\hline Parking & $\$$ & $10,000.00$ & $\$$ & $5,400,000.00$ \\
\hline
\end{tabular}

\begin{tabular}{|l|rr|}
\cline { 2 - 3 } \multicolumn{1}{c|}{} & \multicolumn{3}{c|}{$\begin{array}{c}\text { Construction Cost Infrastructure } \\
\text { Offsites and Infrastructure }\end{array}$} & percent of total & Project Total \\
\hline Offsites and Infrastructure & $8 \%$ & $\mathbf{9 8 3 , 7 5 9 . 2 0}$ \\
\hline
\end{tabular}

\begin{tabular}{|c|c|}
\hline & Total Construction \\
\hline Total Cost & Costs \\
\hline Student Apartments & $\$ 14,964,720.00$ \\
\hline Condominiums & $\$ 11,979,280.00$ \\
\hline Retail & $\$ \quad 6,231,000.00$ \\
\hline Parking & $5,400,000.00$ \\
\hline Offsites and Infrastructure & $483,759.20$ \\
\hline Total Cost & $\$ 39,058,759.20$ \\
\hline
\end{tabular}


ease, comprehensive redevelopment of the University Square Site should be undertaken by one owner/developer. With approximately 5.6 acres, NKT Commercial is the largest property owner, and as a development firm, is envisioned as the primary developer of the Site. Assuming that the land would be sold by the neighbors, and excluding any improvements, expected land costs are estimated at $\$ 65$ per square foot. In this scenario it would cost NKT Commercial approximately $\$ 7,361,640$ for the additional 2.6 acres. Combined with NKT Commercial's current land share, the total land cost is $\$ 23,217,480$.

\subsection{CASH FLOW ANALYSIS}

Table 6.2: The University Square Pro-forma, shows the 20-year cash flow for the project. Income is generated through sales of the condominium and retail units, and renting the student apartments and additional incomes. The condominium units are forecasted to sell for $\$ 350,000$ for two bedroom units, and $\$ 400,000$ for three bedroom units. The total sales revenue for condominiums for year two is forecasted at approximately $\$ 37,500,000$. Retail income is calculated on a square foot basis, with ground-floor retail units at University Square forecasted to sell for $\$ 275$ per square foot. The total sales revenue for retail for year two is forecasted at approximately $\$ 13,915,000$.

Student apartment rental income begins upon project completion in year three. Student apartments are assumed to hold a 95\% occupancy for 9 months of the year, and a $0 \%$ occupancy for 3 months of the year (summer break.). One-

TABLE 6.2a - University Square Pro-Forma Years 1-8

\begin{tabular}{|c|c|c|c|c|c|c|c|c|c|}
\hline Income & year & 1 & 2 & 3 & 4 & 5 & 6 & 7 & 8 \\
\hline \multirow[t]{6}{*}{ Student Apt. Income } & Student Apt. rents less vacancy (1 bedroom) & $\$$ & $\$$ & $470,250.00$ & $\$ 479,655.00$ & $\$ 489,248.10$ & $\$ \quad 499,033.06$ & $\$ \quad 509,013.72$ & $\$ \quad 519,194.00$ \\
\hline & Student Apt. rents less vacancy ( 2 bedroom $)^{*}$ & $\$$ & $\$$ & 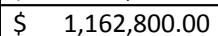 & $\$ 1,186,056.00$ & $\$ 1,209,777.12$ & $\$ 1,233,972.66$ & $\$ 1,258,652.12$ & $\$ 1,283,825.16$ \\
\hline & Student Apt. rents less vacancy ( 3 bedroom $)^{*}$ & $\$$ & $\$$ & $\$ 1,504,800.00$ & $\$ 1,534,896.00$ & $\$ 1,565,593.92$ & $\$ 1,596,905.80$ & $\$ 1,628,843.91$ & $\$ 1,661,420.79$ \\
\hline & additional income (laundry and parking) & $\$$ & $\$$ & $78,125.00$ & $79,687.50$ & $\$ \quad 81,281.25$ & $82,906.88$ & $84,565.01$ & $86,256.31$ \\
\hline & SUM & & & $\$ 3,215,975.00$ & $\$ 3,280,294.50$ & $\$ 3,345,900.39$ & $\$ 3,412,818.40$ & $\$ 3,481,074.77$ & $\$ 3,550,696.26$ \\
\hline & year & 1 & 2 & 3 & & & & & \\
\hline \multirow[t]{4}{*}{ Condo Income } & Condo sales income ( 2 bedroom) & $\$$ & $\$$ & $\$ 17,500,000.00$ & & & & & \\
\hline & Condo sales income (3 bedroom) & $\$$ & $\$$ & $\$ 20,000,000.00$ & & & & & \\
\hline & SUM & $\$$ & $\$$ & $\$ 37,500,000.00$ & & & & & \\
\hline & year & 1 & 2 & 3 & & & & & \\
\hline \multirow[t]{3}{*}{ Retail Income } & Retail sales income & $\$$ & $\$$ & $\$ 13,915,000.00$ & & & & & \\
\hline & SUM & $\$$ & $\$$ & $\$ 13,915,000.00$ & & & & & \\
\hline & year & 1 & 2 & 3 & & & & & \\
\hline \multirow[t]{2}{*}{ Loan Income } & construction loan/principal & $\$ 45,703,802.95$ & $\$$ & $\$$ & & & & & \\
\hline & take out loan principal & $\$$ & $\$$ & $\$ 25,000,000.00$ & & & & & \\
\hline Total Income & & $\$ 45,703,802.95$ & $\$$ & $\$ 79,630,975.00$ & $\$ 3,280,294.50$ & $\$ 3,345,900.39$ & $\$ 3,412,818.40$ & $\$ 3,481,074.77$ & $\$ 3,550,696.26$ \\
\hline \multirow[t]{9}{*}{ Costs } & year & 1 & 2 & 3 & 4 & 5 & 6 & 7 & $\overline{8}$ \\
\hline & land & $\$ 23,217,480.00$ & & & & & & & \\
\hline & construction & $\$ 39,058,759.20$ & & & & & & & \\
\hline & design (6\% of land and construction costs) & $\$ 3,736,574.35$ & & & & & & & \\
\hline & fees & $\$ 4,430,587.00$ & & & & & & & \\
\hline & interest on const. loan (6.25\%) & $\$ 1,428,243.84$ & $\$ \quad 1,428,243.84$ & & & & & & \\
\hline & principal on const. loan & $\$$ & $\$$ & $\$ 45,703,802.95$ & & & & & \\
\hline & take out debt service (4.5\%) & $\$$ & $\$$ & $\$ \quad 1,534,788.57$ & $\$ 1,534,788.57$ & $\$ 1,534,788.57$ & $\$ 1,534,788.57$ & $\$ 1,534,788.57$ & $\$ 1,534,788.57$ \\
\hline & operating costs ( $30 \%$ of rental income) & $\$$ & $\$$ & $964,792.50$ & 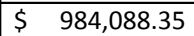 & $\$ 1,003,770.12$ & $\$ 1,023,845.52$ & $\$ 1,044,322.43$ & $\$ 1,065,208.88$ \\
\hline Total Costs & & $\$ 71,871,644.39$ & $\$ 1,428,243.84$ & $\$ 48,203,384.02$ & $\$ 2,518,876.92$ & $\$ 2,538,558.69$ & $\$ 2,558,634.09$ & $\$ 2,579,111.00$ & $\$ 2,599,997.45$ \\
\hline \multirow[t]{2}{*}{ Outcome } & year & 1 & 2 & 3 & 4 & 5 & 6 & 7 & 8 \\
\hline & net & $\$(26,167,841.44)$ & $\$(1,428,243.84)$ & $\$ 31,427,590.98$ & \begin{tabular}{|l|l|}
$\$ 761,417.58$ \\
\end{tabular} & \begin{tabular}{|l|}
$\$ 807,341.70$ \\
\end{tabular} & $854,184.31$ & $\$ 901,963.76$ & \begin{tabular}{|l|l|}
$\$$ & $950,698.81$ \\
\end{tabular} \\
\hline
\end{tabular}

* Assumes vacancy rate of $5 \%$ for 9 months

** Year three assumes a paydown debt of $\$ 37,304,905.00$ 
bedroom apartments are forecasted to rent for $\$ 1,100$ per month, two-bedrooms for $\$ 1,700$ per month, and three-bedrooms for $\$ 2,200$ per month. Additional monthly incomes are generated through laundry operations and parking. While 1 parking space comes with each of the condominiums, the 215 student parking spaces are rented for $\$ 250$ for a 9 month lease. Laundry income is estimated at $\$ 12.50$ per unit/per month. Additional rental income may be generated from summer rentals, however, this was not assumed during this analysis.

Project costs include land, construction, design, permits and fees, and loan debt service. The two-year construction loan from Cal Poly takes into account construction costs, design, and permits and fees, for a combined total of approximately $\$ 45.7$ million. The $6.25 \%$ annual interest charged by Cal Poly on the loan totals approximately $\$ 1.4$ million per year. All land purchases would have to be undertaken prior to construction and are not included in the construction loan

While the burden of the construction loan principle becomes due upon project completion in year three, the combined condominiums and retail sales, and student housing rental income offsets this cost by generating a significant profit. Long-term debt service is offset by using some of the third-year profit $(\$ 37,305,904)$ to pay-down debt and decrease the long-term take-out loan principle. The take-out loan of $\$ 25$ million could be lessened if the developer was willing to take a reduction in third year profits for higher returns on years 4-20. However, this analysis assumes the theory of net-present value, whereby

TABLE 6.2b - University Square Pro-Forma Years 9-20

\begin{tabular}{|c|c|c|c|c|c|c|c|c|c|c|c|}
\hline 9 & 10 & 11 & 12 & 13 & 14 & 15 & 16 & 17 & 18 & 19 & 20 \\
\hline$\$ \quad 529,577.88$ & $\$ \quad 540,169.44$ & $\$ \quad 550,972.82$ & $\$ \quad 561,992.28$ & $\$ \quad 573,232.13$ & $\$ \quad 584,696.77$ & $\$ \quad 596,390.70$ & $\$ \quad 608,318.52$ & $\$ \quad 620,484.89$ & $\$ 632,894.59$ & $\$ \quad 645,552.48$ & $\$ \quad 658,463.53$ \\
\hline$\$ 1,309,501.66$ & $\$ 1,335,691.69$ & $\$ 1,362,405.53$ & $\$ 1,389,653.64$ & $\$ 1,417,446.71$ & $\$ 1,445,795.65$ & $\$ 1,474,711.56$ & $\$ 1,504,205.79$ & $\$ 1,534,289.91$ & $\$ 1,564,975.70$ & $\$ 1,596,275.22$ & $\$ 1,628,200.72$ \\
\hline$\$ 1,694,649.21$ & $\$ 1,728,542.19$ & $\$ 1,763,113.04$ & $\$ 1,798,375.30$ & $\$ 1,834,342.80$ & $\$ 1,871,029.66$ & $\$ 1,908,450.25$ & $\$ 1,946,619.26$ & $\$ 1,985,551.64$ & $\$ 2,025,262.68$ & $\$ 2,065,767.93$ & $\$ 2,107,083.29$ \\
\hline$\$ \quad 87,981.44$ & $89,741.07$ & $91,535.89$ & $93,366.61$ & $95,233.94$ & $97,138.62$ & $99,081.39$ & $\$ 101,063.02$ & $\$ 103,084.28$ & $\$ 105,145.96$ & $\$ 107,248.88$ & $\$ 109,393.86$ \\
\hline$\$ 3,621,710.19$ & $\$ 3,694,144.39$ & $\$ 3,768,027.28$ & $\$ 3,843,387.82$ & $\$ 3,920,255.58$ & $\$ 3,998,660.69$ & $\$ 4,078,633.91$ & $\$ 4,160,206.58$ & $\$ 4,243,410.72$ & $\$ 4,328,278.93$ & $\$ 4,414,844.51$ & $\$ 4,503,141.40$ \\
\hline & & & & & & & & & & & \\
\hline & & & & & & & & & & & \\
\hline & & & & & & & & & & & \\
\hline & & & & & & & & & & & \\
\hline & & & & & & & & & & & \\
\hline & & & & & & & & & & & \\
\hline & & & & & & & & & & & \\
\hline & & & & & & & & & & & \\
\hline & & & & & & & & & & & \\
\hline & & & & & & & & & & & \\
\hline$\$ 3,621,710.19$ & $\$ 3,694,144.39$ & $\$ 3,768,027.28$ & $\$ 3,843,387.82$ & $\$ 3,920,255.58$ & $\$ 3,998,660.69$ & $\$ 4,078,633.91$ & $\$ 4,160,206.58$ & $\$ 4,243,410.72$ & $\$ 4,328,278.93$ & $\$ 4,414,844.51$ & $\$ 4,503,141.40$ \\
\hline
\end{tabular}

\begin{tabular}{|c|c|c|c|c|c|c|c|c|c|c|c|}
\hline 9 & 10 & 11 & 12 & 13 & 14 & 15 & 16 & 17 & 18 & 19 & 20 \\
\hline & & & & & & & & & & & \\
\hline & & & & & & & & & & & \\
\hline & & & & & & & & & & & \\
\hline & & & & & & & & & & & \\
\hline & & & & & & & & & & & \\
\hline & & & & & & & & & & & \\
\hline$\$ 1,534,788.57$ & $\$ 1,534,788.57$ & $\$ 1,534,788.57$ & $\$ 1,534,788.57$ & $\$ 1,534,788.57$ & $\$ 1,534,788.57$ & $\$ 1,534,788.57$ & $\$ 1,534,788.57$ & $\$ 1,534,788.57$ & $\$ 1,534,788.57$ & $\$ 1,534,788.57$ & $\$ 1,534,788.57$ \\
\hline$\$ 1,086,513.06$ & $\$ 1,108,243.32$ & $\$ 1,130,408.18$ & $\$ 1,153,016.35$ & $\$ 1,176,076.67$ & $\$ 1,199,598.21$ & \begin{tabular}{|l|}
$1,223,590.17$ \\
\end{tabular} & $\$ 1,248,061.98$ & $\$ 1,273,023.21$ & $\$ 1,298,483.68$ & $\$ 1,324,453.35$ & $\$ 1,350,942.42$ \\
\hline$\$ 2,621,301.63$ & $\$ 2,643,031.89$ & $\$ 2,665,196.76$ & $\$ 2,687,804.92$ & $\$ 2,710,865.25$ & $\$ 2,734,386.78$ & $\$ 2,758,378.74$ & $\$ 2,782,850.55$ & $\$ 2,807,811.79$ & $\$ 2,833,272.25$ & $\$ 2,859,241.93$ & $\$ 2,885,730.99$ \\
\hline
\end{tabular}

\begin{tabular}{|c|c|c|c|c|c|c|c|c|c|c|c|}
\hline 9 & 10 & 11 & 12 & 13 & 14 & 15 & 16 & 17 & 18 & 19 & 20 \\
\hline$\$ 1,000,408.56$ & $\$ 1,051,112.50$ & $\$ 1,102,830.52$ & $\$ 1,155,582.90$ & $\$ 1,209,390.33$ & $\$ 1,264,273.91$ & $\$ 1,320,255.16$ & $\$ 1,377,356.04$ & $\$ 1,435,598.93$ & $\$ 1,495,006.68$ & $\$ 1,555,602.58$ & $\$ 1,617,410.41$ \\
\hline
\end{tabular}


monies in the present are higher in value than they would be in the future. Thus the $\$ 25$ million take out loan allows for an approximately $\$ 31.5$ million profit in year three. Under this assumption the combined rental income generated in years 4-20 approximates $\$ 1$ million/per year, with the early years generating slightly less and the later years slightly more with $2 \%$ annual rent increases. The $\$ 37$ million paydown debt allows for a smaller up front profit in year 3 , but allows for this steady revenue stream for years $4-20$. The take out loan (take out debt service) is at a rate of $4.5 \%$ annually, which was assumed from discussions with local developers and real estate professionals.

From this first take on a financial analysis, the University Square Development Proposal makes sense, netting the project developer a significant profit. However, this analysis is by necessity limited in scope and further financial analysis would need to be undertaken to better understand cash-flow, tax implications, project time line, and sales costs. 
THIS PAGE INTENTIONALLY LEFT BLANK 
CONCLUSIONS 
THIS PAGE INTENTIONALLY LEFT BLANK 


\subsection{EVALUATING THE PROJECT}

In Section 1 of this proposal the five following project objectives were outlined:

1) Feasibility: Achieve a financially feasible design and development solution for the University Square Site.

2) Sense of Place: Provide a design that rehabilitates the Site's image and creates a unique sense of place.

3) Multi-Modal Transportation: Create opportunities for residents and visitors to use alternative modes of transportation such as walking, bicycling, and transit.

4) Housing: Develop housing for both Cal Poly students and the local San Luis Obispo community.

5) Sustainability: Design with the natural environment in mind and provide sustainable solutions that negates the project's environmental impact and enhances the Site's environmental quality.

Each of these objectives was considered throughout the USDP, and can be seen in Section 4: Program Development, Section 5: Project Development, and Section 6: Financing. To make sure that the USDP achieved these objectives, this proposal utilized two qualitative evaluation strategies. The first strategy used the Urban Design Matrix developed in Section 2 of this Proposal. The results, which are displayed in Figure 7.1, show that the University Square Site is an effective urban design project, with 19 out of 20 total points. The project

FIGURE 7.1 - University Square Urban Design Matrix

\begin{tabular}{|c|c|c|c|}
\hline $\begin{array}{l}\text { Urban Design } \\
\text { Principle }\end{array}$ & Good (2) & Fair (1) & Poor (0) \\
\hline Human Scale & & $\mathrm{X}$ & \\
\hline Respect for Pedestrian & $\mathrm{X}$ & & \\
\hline Variety in Land Uses & $x$ & & \\
\hline Variety in Human Activities & $\mathrm{X}$ & & \\
\hline $\begin{array}{l}\text { Well Maintained Buildings } \\
\text { and Public Spaces }\end{array}$ & $\mathrm{X}$ & & \\
\hline Inclusion of Green Space & $\mathrm{X}$ & & \\
\hline $\begin{array}{l}\text { Building Set-backs Close } \\
\text { to the Street }\end{array}$ & $\mathrm{x}$ & & \\
\hline $\begin{array}{l}\text { Unified Building and } \\
\text { Natural Materials }\end{array}$ & $\mathrm{X}$ & & \\
\hline Functionality & $\mathrm{X}$ & & \\
\hline $\begin{array}{l}\text { Connections and } \\
\text { Permeability }\end{array}$ & $x$ & & \\
\hline
\end{tabular}

respects the pedestrian, contains a variety of land uses and human activities, and includes green space and buildings with set-backs close to the street.

One critique that may be given of the urban design is that some portions of the project may not be to human scale, and that the large student apartment building creates a large street wall on Highway 1/Santa Rosa that precludes a pedestrian atmosphere. While this critique is valid, the design was seen as necessary to achieve the density required by the development program. Commercial frontages and front doors on Highway 1/Santa Rosa were also seen as unappealing to business owners due to the high-speed of vehicle traffic and lack of street parking.

The second strategy used to evaluate the USDP is the Mixed-Use Development Matrix developed in Section 2 of this Proposal. The results, which are displayed in Figure 7.2, show that overall the USDP is an effective mixed-use development project, with 10 out of 14 total points. The project was especially strong in defining clear objectives, providing a cornerstone use (multi-family residential with both condominiums and student housing), creating value for investors, and providing sustainability strategies.

The project was slightly weaker in both treating the public sector as a client and understanding the market. Although the desires of the City and the LUCE update were expressed in the USDP, greater consultation could have been conducted with City entities such as the planning department. Also, a better

FIGURE 7.2 - University Square Mixed-Use Development Matrix

\begin{tabular}{|l|c|c|c|}
\hline \multicolumn{1}{|c|}{$\begin{array}{c}\text { Mixed-Use } \\
\text { Development } \\
\text { Principle }\end{array}$} & Good (2) & Fair (1) & Poor (0) \\
\hline Clearly Defined Objectives & $\mathrm{X}$ & & \\
\hline Cornerstone Use & $\mathrm{X}$ & $\mathrm{X}$ & \\
\hline $\begin{array}{l}\text { Public Sector Treated as } \\
\text { a Partner }\end{array}$ & & $\mathrm{X}$ & \\
\hline Understanding the Market & $\mathrm{X}$ & & \\
\hline Create Value for Investors & $\mathrm{X}$ & & $\mathrm{X}$ \\
\hline Sustainability & & & \\
\hline Availability of Funds & & & \\
\hline
\end{tabular}


understanding of the market would have been beneficial, and further market analysis could have really helped to create a more specified program. One of the major weaknesses of the project that is identified in the Mixed-Use Development Matrix is the lack of identified availability of funds. Though the USDP looks towards Cal Poly as a funding partner, there would likely be deficient funds and alternative financing sources would need to be considered further along in the development process.

\subsection{LESSONS LEARNED}

This project was a great learning experience. I learned a lot about urban design, mixed-use development, and how complicated the development business is. A few lessons learned from this project include:

\subsubsection{It Takes a Team!}

When I started this project I was excited to be doing something on my own/ being my own boss. But as I progressed it was just me doing all this work. Projects of this scope really require a team and it definitely helped bouncing ideas off you guys, but it would have really helped to have an entire team behind the project.

\subsubsection{Aggressive Time-Line}

The project may take longer than two years to construct. If I was to do it over again I would have to account for a longer construction time-line and possibly phasing options.

\subsubsection{The Fire Station}

Finally I didn't take into account the cost of moving the fire station. The City has said it is open to moving it, but this would likely be an additional cost beyond just the land purchase. 
REEERENCGES 
THIS PAGE INTENTIONALLY LEFT BLANK 
CA NCDC (2010), 1981-2010 Monthly Normals, http://www.ncdc.noaa. gov/land-based-station-data/climate-normals/1981-2010normals-data, Retrieved on 2013-11-27

Carmona, M., Tisdell, S., Heath, T., \& Oc, T. (2010). Public Places Urban Spaces. (2nd ed.). New York, NY: Routledge.

Dunham-Jones, E., \& Williamson, J. (2009). Retrofitting Suburbia. Hoboken, New Jersey: John Wiley \& Sons

Forest City Science and Technology Group (2013), University Park at MIT. Retrieved from: http://www.forestcityscience.net/mit/ sciencepark_plan.shtml. Retrieved on 2013-11-27

Katz, P. (1994). The New Urbanism. New York, NY: McGraw-Hill, Inc.

Kriken, J.L. (2010). City Building. New York, NY: Princeton Architectural Press.

Lazier, Matt (2013), Cal Poly San Luis Obispo, University News and Information, Cal Poly Announces Plans for New Student Housing Complex, http://calpolynews.calpoly.edu/news_releases/2013/ May/dorm.html, Retrieved on 2013-11-27

Miles, M. E., Haney, Jr., R. L., \& Berens, G. (1996). Real Estate Development Principles and Process. (2nd ed.). Washington D.C.: Urban Land Institute.

Mustang Village, Floor Plans http://www.mustangvillage.com/Floor-Plans. aspx. Retrieved on 2014-04-29

Ratcliffe, J., Stubbs, M., \& Keeping, M. (2009). Urban Planning and Real Estate Development. (3rd Edition ed.). New York, NY: Routledge.

Saporata, M. (2013), Georgia Tech marks the 10th anniversary of Technology Square. Retrieved from: http://saportareport.com/ blog/2013/10/georgia-tech-marks-the-10th-anniversary-oftechnology-square/. Retrieved on 2013-11-27
Schwanke , D. et al. (2003). Mixed-Use Development Handbook. (2nd Edition ed.). Washington D.C.: Urban Land Institute.

Smith, H., Tschappat, C., \& Racster, R. (1977). Real Estate and Urban Development. (Revised Edition ed.). Homewood, II.: Richard D. Irwin, Inc.

South Campus Gateway (2013), South Campus Gateway. Retrieved from: http://www.southcampusgateway.com/about.html. Retrieved on 2013-11-27

The Tribune (2013) The San Luis Obispo Tribune (The Tribune), Cal Poly should consider increasing student enrollment by as much as 5,000 president says, http://www.sanluisobispo.com/2013/09/16/2685966/ cal-poly-president-student-population.html, Retrieved on 2013-11-27

Washburn, A. (2013). The Nature of Urban Design. Washington D.C.: Island Press. 
THIS PAGE INTENTIONALLY LEFT BLANK 


\section{APPENDIXA}


THIS PAGE INTENTIONALLY LEFT BLANK 


\section{CASE STUDY ANALYSIS}

\section{A.1 INTRODUCTION}

The Case Study Analysis builds upon the Literature Review in Section 2 by utilizing the Urban Design Matrix and Mixed-Use Development Matrix in concert to evaluate four case studies that are analogous to the conditions and typology proposed at University Square. These are South Campus Gateway at The Ohio State University, Technology Square at the Georgia Institute of Technology, and University Park at the Massachusetts Institute of Technology. Each of these case studies shares the two following characteristics:

1) They are all mixed-use development projects of various sizes, scales, and mixes

2) They are all partnerships between North American public universities and outside developers and/or investors.

While these characteristics are universal to all of three case studies, each one had its own unique circumstances that prescribed the project's design, financing, and time line. This analysis will explore these unique circumstances, while also looking at the commonalities through the matrixes evaluations.

\section{A.2 SOUTH CAMPUS GATEWAY - THE OHIO STATE UNIVERSITY}

\section{A.2.1 PROJeCt DEscriPtION}

Opened in 2005, the South Campus Gateway development in downtown Columbus, Ohio, is a 7.5 acre mixed-use development adjacent to The Ohio State University that is the result of a partnership between the City and the University in an effort to improve the urban area known collectively as the "University District." Located on High Street, adjacent to The Ohio State University campus, South Campus Gateway hosts a university bookstore,
Key facts: South Campus Gateway

- 7.5 ACRES

- 7 BUILDING MIXED-USE ENTERTAINMENT COMPLEX

- 3 CITY BLOCKS

- APARTMENTS, OFFICE, RETAL, PARKING gARAge

- BUILT BY CAMPUS PARTNERS (CITY/UNIVERSITY NON-PROFIT)

184 apartments, retail shops, art galleries, offices, several restaurants and nightclubs, and a 1,200-space parking garage (Campus Partners, 2013).

\section{A.2.2 Urban Design Matrix Evaluation}

\begin{tabular}{|l|c|c|c|}
\hline \multicolumn{1}{|c|}{$\begin{array}{c}\text { Urban Design } \\
\text { Principle }\end{array}$} & Good (2) & Fair (1) & Poor (0) \\
\hline Human Scale & & X & \\
\hline Respect for Pedestrian & $X$ & & \\
\hline Variety in Land Uses & $X$ & & \\
\hline Variety in Human Activities & $X$ & & \\
\hline $\begin{array}{l}\text { Well Maintained Buildings } \\
\text { and Public Spaces }\end{array}$ & $\mathrm{X}$ & & \\
\hline Inclusion of Green Space & $\mathrm{X}$ & \\
\hline $\begin{array}{l}\text { Building Set-backs Close } \\
\text { to the Street }\end{array}$ & $\mathrm{X}$ & & \\
\hline $\begin{array}{l}\text { Unified Building and } \\
\text { Natural Materials }\end{array}$ & $\mathrm{X}$ & & \\
\hline Functionality & $\mathrm{X}$ & & \\
\hline $\begin{array}{l}\text { Connections and } \\
\text { Permeability }\end{array}$ & & & \\
\hline
\end{tabular}

South Campus Gateway scored exceptionally high on all but two of the urban design qualities for a total of seventeen (17) points. The development scored fairly on human scale due to the uniform massing of some of the taller buildings, where better human scale could have been created through more articulation in the buildings footprint or increased upper story setbacks. Additionally the development scored poorly on inclusion of green space because it completely lacked the addition of any green space. While 52 new trees were planted throughout the South Campus Gateway property during construction (Campus Partners, 2013), no new green space was provided. The developments nonverdant landscape is likely due to its urban environment and relatively small size. 


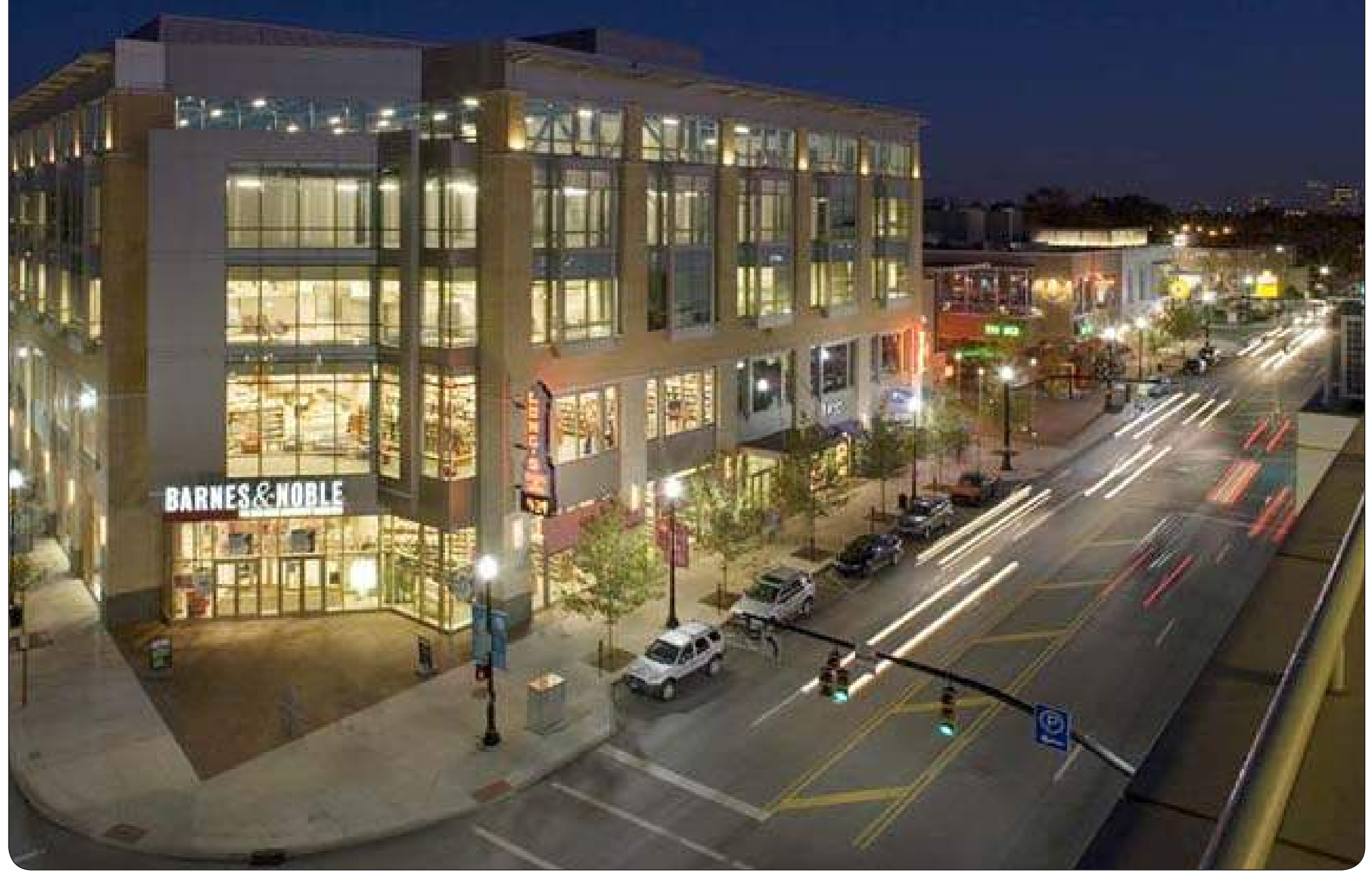

SOUTH CAMPUS GATEWAY, A DEVELOPMENT BUILT BY CAMPUS PARTNERS (A PARTNERSHIP BETWEEN THE OHIO STATE UNIVERSITY AND THE CITY OF COLUMBUS.) PHOTO CREDIT: Campus Partners 
A.2.3 Mixed-Use Development Matrix Evaluation

\begin{tabular}{|l|c|l|l|}
\hline \multicolumn{1}{|c|}{$\begin{array}{c}\text { Mixed-Use } \\
\text { Development } \\
\text { Principle }\end{array}$} & Good (2) & Fair (1) & Poor (0) \\
\hline Clearly Defined Objectives & $X$ & & \\
\hline Cornerstone Use & $X$ & & \\
\hline $\begin{array}{l}\text { Public Sector Treated as } \\
\text { a Partner }\end{array}$ & $\mathrm{X}$ & & \\
\hline $\begin{array}{l}\text { Understanding of the } \\
\text { Market }\end{array}$ & & & \\
\hline Create Value for Investors & & & \\
\hline Sustainability & $\mathrm{X}$ & & \\
\hline Availability of Funds & & & \\
\hline
\end{tabular}

Evaluating South Campus Gateway from a real estate development perspective proved challenging due to a lack of available information. Thus, the MixedUse Development Matrix could not be completed. However, based upon the principles that could be evaluated, the development obtained only good scores. The project had the clearly defined objective to serve as a gateway project for the University District, it had a clear cornerstone use in the flagship Ohio State Bookstore, had a clear partnership between the City and University, and included sustainability in design, construction and operation.

\section{A.2.4 CONCLUSIONS}

South Campus Gateway is an excellent example of a medium-scale mixed-use project in a medium sized City. With a broad mixture of commercial, residential, parking, and office, the development effectively integrated good urban design and mixed-use development principles. At almost the exact same size as the University Square Site, South Campus Gateway provides a model to follow in terms of development typologies, mix of uses, and effective integration with both City and Campus.

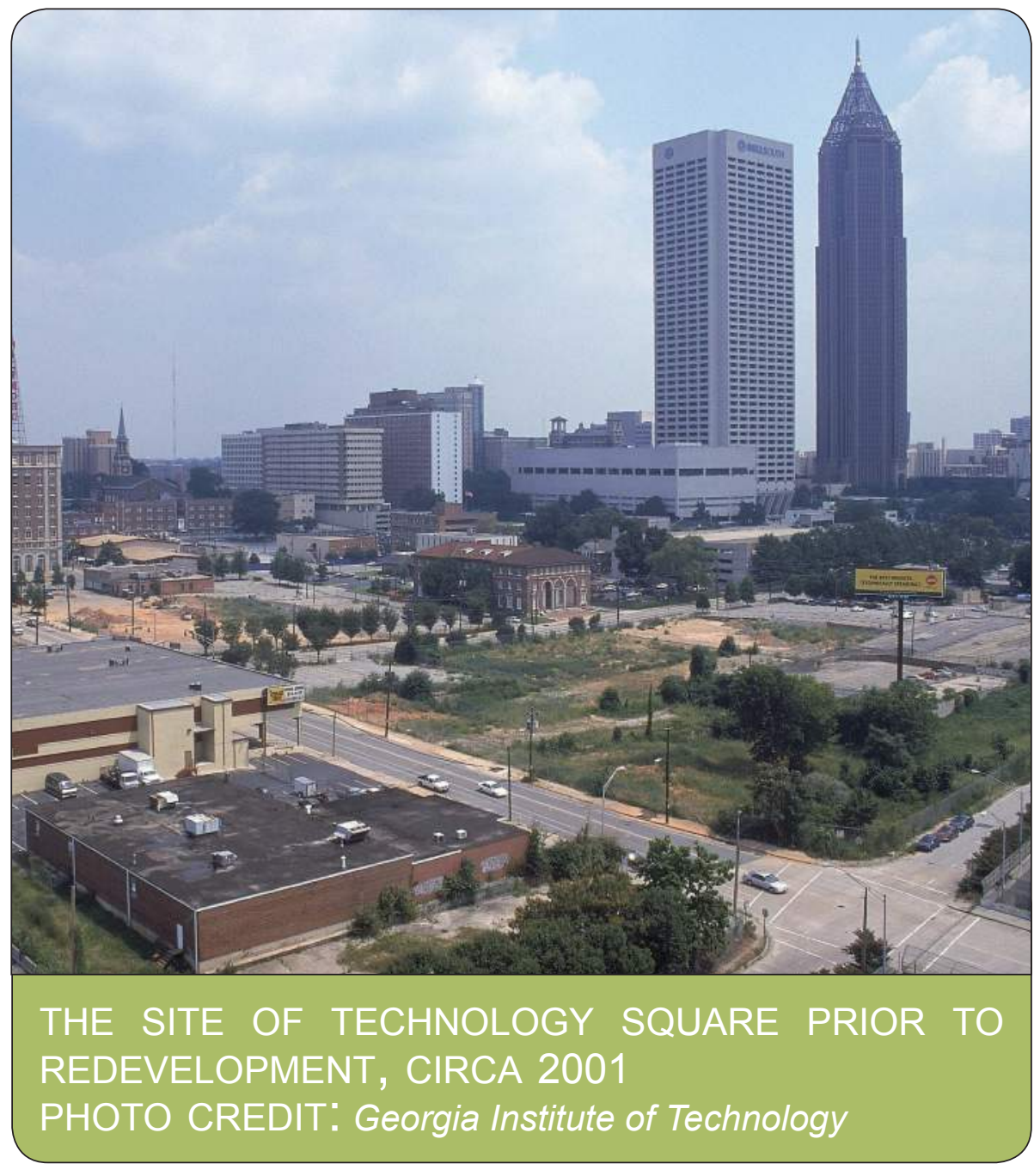

\section{A.3 TECHNOLOGY SQUARE - GEORGIAINSTITUTE OF TECHNOLOGY}

\section{A.3.1 Project Description}

Opened in 2003, Technology Square is a mixed-use development connecting Downtown Atlanta to the campus of The Georgia Institute of Technology (Georgia Tech.) The eight (8 acre) development includes Georgia Tech's Dupree College of Management, a hotel and conference center, offices, retail shops and restaurants, parking, and condominiums. The development was 


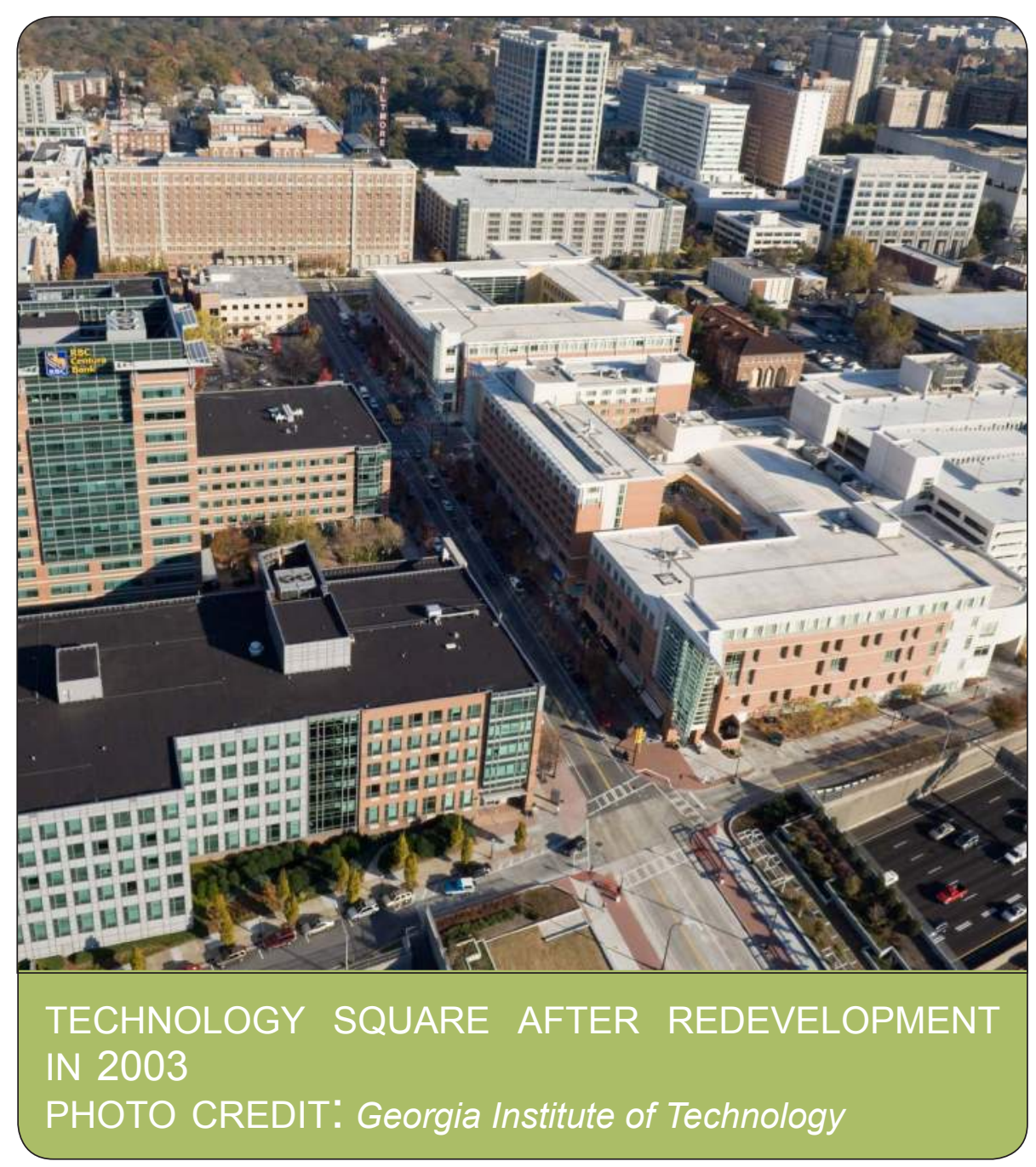

built over a previously vacant surface parking lot and aimed to revitalize the midtown neighborhood of Atlanta and reconnect the City with the University. Though mostly a development driven by the University (Technology Square adds 1.12 million square feet to Georgia Tech's campus), Technology Square represented a political partnership between Atlanta and the University (Saporta Report, 2013).
Key FACTS: TECHNOLOgY SQuARE

\section{- 8 ACRES}

- 1.12 MILLION SQUARE FEET ADDITION TO GEORGIA TECH'S CAMPUS

- 4 CITY BLOCKS

- ApARTMENTS, OFFICE, RETALL, PARKING garage

- built by Georgia Tech Partners

\section{A.3.2 Urban Design Matrix Evaluation}

Technology Square is an excellent example of a mixed-use development built on approximately the same number of acres as University Square. It demonstrates how multi-storied buildings can respect human scale and pedestrians through unified building materials, staggered setbacks, and interesting facade detailing. Technology Square scored exceedingly high on the urban design matrix with a total of eighteen (18) points. The development has a healthy variety of land uses, has well maintained buildings and public spaces, includes green spaces, and is high functioning and seamlessly integrated into the surrounding City. Though it is unlikely that the density and height of the buildings in Technology Square could be matched to the University Square Site due to the different political climate and physical makeup of Atlanta versus San Luis Obispo, Technology Square nonetheless presents an excellent urban design example to be followed.

\begin{tabular}{|c|c|c|c|}
\hline $\begin{array}{l}\text { Urban Design } \\
\text { Principle }\end{array}$ & Good (2) & Fair (1) & Poor (0) \\
\hline Human Scale & $\mathrm{X}$ & & \\
\hline Respect for Pedestrian & $\mathrm{X}$ & & \\
\hline Variety in Land Uses & $\mathrm{x}$ & & \\
\hline Variety in Human Activities & & $\mathrm{X}$ & \\
\hline $\begin{array}{l}\text { Well Maintained Buildings } \\
\text { and Public Spaces }\end{array}$ & $\mathrm{X}$ & & \\
\hline Inclusion of Green Space & & $x$ & \\
\hline $\begin{array}{l}\text { Building Set-backs Close } \\
\text { to the Street }\end{array}$ & $\mathrm{x}$ & & \\
\hline $\begin{array}{l}\text { Unified Building and } \\
\text { Natural Materials }\end{array}$ & $\mathrm{x}$ & & \\
\hline Functionality & $\mathrm{X}$ & & \\
\hline $\begin{array}{l}\text { Connections and } \\
\text { Permeability }\end{array}$ & $x$ & & \\
\hline
\end{tabular}


A.3.3 Mixed-Use Development Matrix Evaluation

\begin{tabular}{|l|c|l|c|}
\hline \multicolumn{1}{|c|}{$\begin{array}{c}\text { Mixed-Use } \\
\text { Development } \\
\text { Principle }\end{array}$} & Good (2) & Fair (1) & Poor (0) \\
\hline Clearly Defined Objectives & $\mathrm{X}$ & & \\
\hline Cornerstone Use & $\mathrm{X}$ & & \\
\hline $\begin{array}{l}\text { Public Sector Treated as } \\
\text { a Partner }\end{array}$ & $\mathrm{X}$ & & \\
\hline $\begin{array}{l}\text { Understanding of the } \\
\text { Market }\end{array}$ & $\mathrm{X}$ & & \\
\hline Create Value for Investors & & & \\
\hline Sustainability & & & $\mathrm{X}$ \\
\hline Availability of Funds & & & \\
\hline
\end{tabular}

As in the South Campus Gateway case study, evaluating Technology Square from a real estate development perspective proved challenging due to a lack of available financial information. Thus some assumptions were made when evaluating the development using the Mixed-Use Development Matrix, and some of the principles could not be realistically evaluated. The excluded principles include creating value for investors and availability of funds. Nevertheless the project demonstrated excellent real estate development principles through clearly defined objectives (revitalizing Atlanta's Midtown neighborhood, urbanizing Georgia Tech's campus, etc...), having two strong cornerstone uses in the Barnes and Nobles bookstore, and the Dupree College of Management, treating the public sector as a partner, and understanding the market. The only category that the development scored poorly in was sustainability, as none of the available literature or information indicated that there was any sustainable development strategies.

\section{A.3.4 CONCLUSIONS}

Technology Square is an excellent example of an effective and successful mixed-use development on a small site. Well it's urban context is significantly different from that of University Square, the development still serves as an example of integrated urban design and real estate development to be followed. The lacking financial information would have been helpful and it is a shortcoming of this analysis that it could not have been further analyzed. Some of the principles most applicable to University Square include the building typologies, mix of uses, and public sector partnerships.

\section{A.4 UNIVERSITY PARK AT MIT -MASSACHUSETTS INSTITUTE OF TECHNOLOGY}

\section{A.4.1 Project Description}

Designed by Koetter Kim \& Associates, and developed by Forest City Science and Technology Group, University Park was developed on a 27 acre industrial graveyard. The project successfully integrated 1.5 million square feet of scientific research facilities with more than 670 residential units, a hotel and conference center, retail amenities, for a total of 2.3 million square feet (Forest City Science and Technology Group).. University Park is directly adjacent to the MIT main campus, two Cambridge neighborhoods and directly across the water from downtown Boston. The project demonstrates successful integration with the University, the surrounding Cities, and the local business community.

\section{A.4.2 Urban Design Matrix Evaluation}

With a total of nineteen (19) points, the University Park development exhibits almost all of the good urban design qualities. The only quality it scored lower in was human scale due to the large building massing and relative lack of articulation. However, the architecture does speak to the urban New England vernacular, and matches the materials used at MIT and the surrounding Cambridge neighborhoods. There is a variety in land uses and

\begin{tabular}{|l|c|c|c|}
\hline \multicolumn{1}{|c|}{$\begin{array}{c}\text { Urban Design } \\
\text { Principle }\end{array}$} & Good (2) & Fair (1) & Poor (0) \\
\hline Human Scale & & $\mathrm{X}$ & \\
\hline Respect for Pedestrian & $\mathrm{X}$ & & \\
\hline Variety in Land Uses & $\mathrm{X}$ & & \\
\hline Variety in Human Activities & $\mathrm{X}$ & & \\
\hline $\begin{array}{l}\text { Well Maintained Buildings } \\
\text { and Public Spaces }\end{array}$ & $\mathrm{X}$ & & \\
\hline Inclusion of Green Space & $\mathrm{X}$ & & \\
\hline $\begin{array}{l}\text { Building Set-backs Close } \\
\text { to the Street }\end{array}$ & $\mathrm{X}$ & & \\
\hline $\begin{array}{l}\text { Unified Building and } \\
\text { Natural Materials }\end{array}$ & $\mathrm{X}$ & & \\
\hline Functionality & $\mathrm{X}$ & & \\
\hline $\begin{array}{l}\text { Connections and } \\
\text { Permeability }\end{array}$ & & & \\
\hline
\end{tabular}


KEY FACTS: UNIVERSITY PARK

- $\$ 750$ MILLION = TOTAL PROJECT COST

- 2.3 MILLION TOTAL SQUARE FEET

- Residential, office, Research and deVelopment, HOTEL, AND RETAIL

- WiNNER OF ULI'S 2004 AWARD FOR EXCELLENCE

- BUILT BY FOREST CITY SCIENCE AND TECHNOLOGY GROUP

human activities that includes University related enterprises, private offices, restaurants and bars, and residential options. University Park also includes three acres of parks and green space, and has well maintained buildings and public spaces. The development is high functioning with access by car, bus, bike, or subway,. University Park is also served by EZRide, a shuttle service that connects University Park with Kendall Square, East Cambridge, and North Station (Forest City Science and Technology Group, 2013).

\section{A.4.3 Mixed-Use Development Matrix Evaluation}

\begin{tabular}{|l|c|c|c|}
\hline \multicolumn{1}{c|}{$\begin{array}{c}\text { Mixed-Use } \\
\text { Development } \\
\text { Principle }\end{array}$} & Good (2) & Fair (1) & Poor (0) \\
\hline Clearly Defined Objectives & $\mathrm{X}$ & & \\
\hline Cornerstone Use & $\mathrm{X}$ & & \\
\hline $\begin{array}{l}\text { Public Sector Treated as } \\
\text { a Partner }\end{array}$ & $\mathrm{X}$ & & \\
\hline $\begin{array}{l}\text { Understanding of the } \\
\text { Market }\end{array}$ & $\mathrm{X}$ & & \\
\hline Create Value for Investors & $\mathrm{X}$ & & $\mathrm{X}$ \\
\hline Sustainability & & & \\
\hline Availability of Funds & & & \\
\hline
\end{tabular}

The design and development of University Park took over 20 years, with 5 phases and cost a total of $\$ 750$ million. By engaging the public at an early stage the development was able to gain traction and earn investors. Forest City Scence and Technology Group, a subsidiary of Forest City Enterprises, Inc. was the primary developer, with MIT as the primary landholder. While MIT continues to own the land, Forest City holds long-term leases (Forest City Science and Technology Group, 2013). The project currently has 100 percent

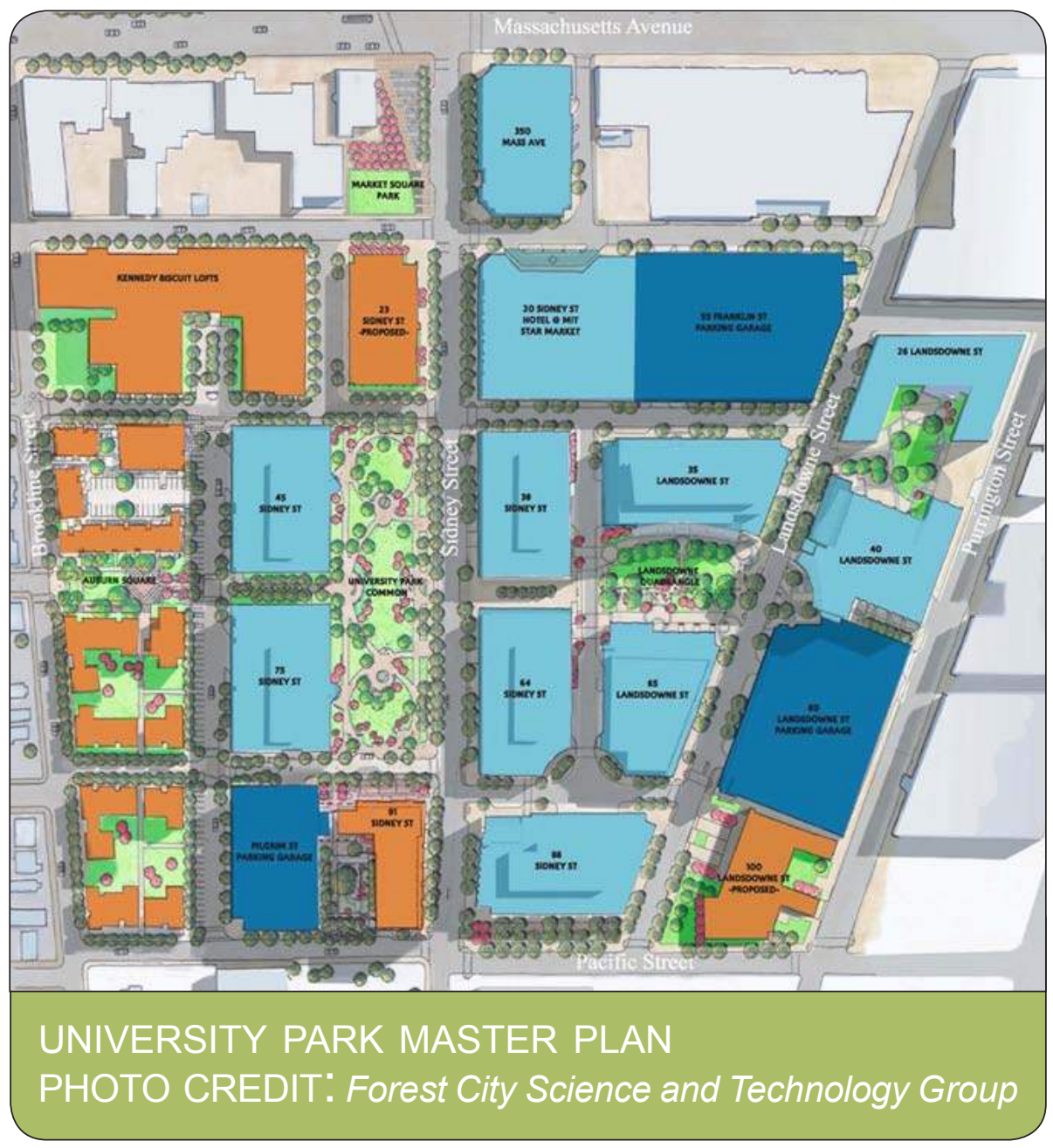

occupancy on all office and commercial enterprises, and has a successful residential market. Thus the development scored highly on the Mixed-Use Development Matrix in almost all qualities. The exceptions were the public sector treated as a partner and sustainability. Though the public was consulted and the project integrates with Cambridge, the City was never treated as a direct partner in the process. Additionally, the project was largely built in the 1990's when sustainability was just beginning to be discussed, and was not a priority. Overall the development was successful in creating value for investors, and had access to capital with an established and successful development group at the helm. The market was clearly understood, and the development had clearly defined objectives to increase the size of the University's campus, housing opportunities and expanded business partnerships. 


\section{A.4.4 CONCLUSIONS}

While University Park is a success in terms of both urban design and real estate development it's 27 acres make it a much larger project in overall terms that the 7.5 acre University Square proposal. However, University Park does demonstrate qualities that are applicable to the University Square site. One takeaway is to promote architecture that is consistent with the local context and respects the area's traditions and history. University Park does this in its architecture and public spaces, but particularly does this with it's public art program. University Park includes over 100 sculptural and graphic pieces as part of Traces, an artwork that marks moments in the 250 year history of the site. Commissioned by Forest City Boston, Traces tells stories of 18th and 19th century commerce and of technical innovations made in the local area (Forest City Science and Technology Group, 2013). A public art program similar to this could be incorporated at the University Square site to better integrate it with the community and provide increased visual interest in the area.

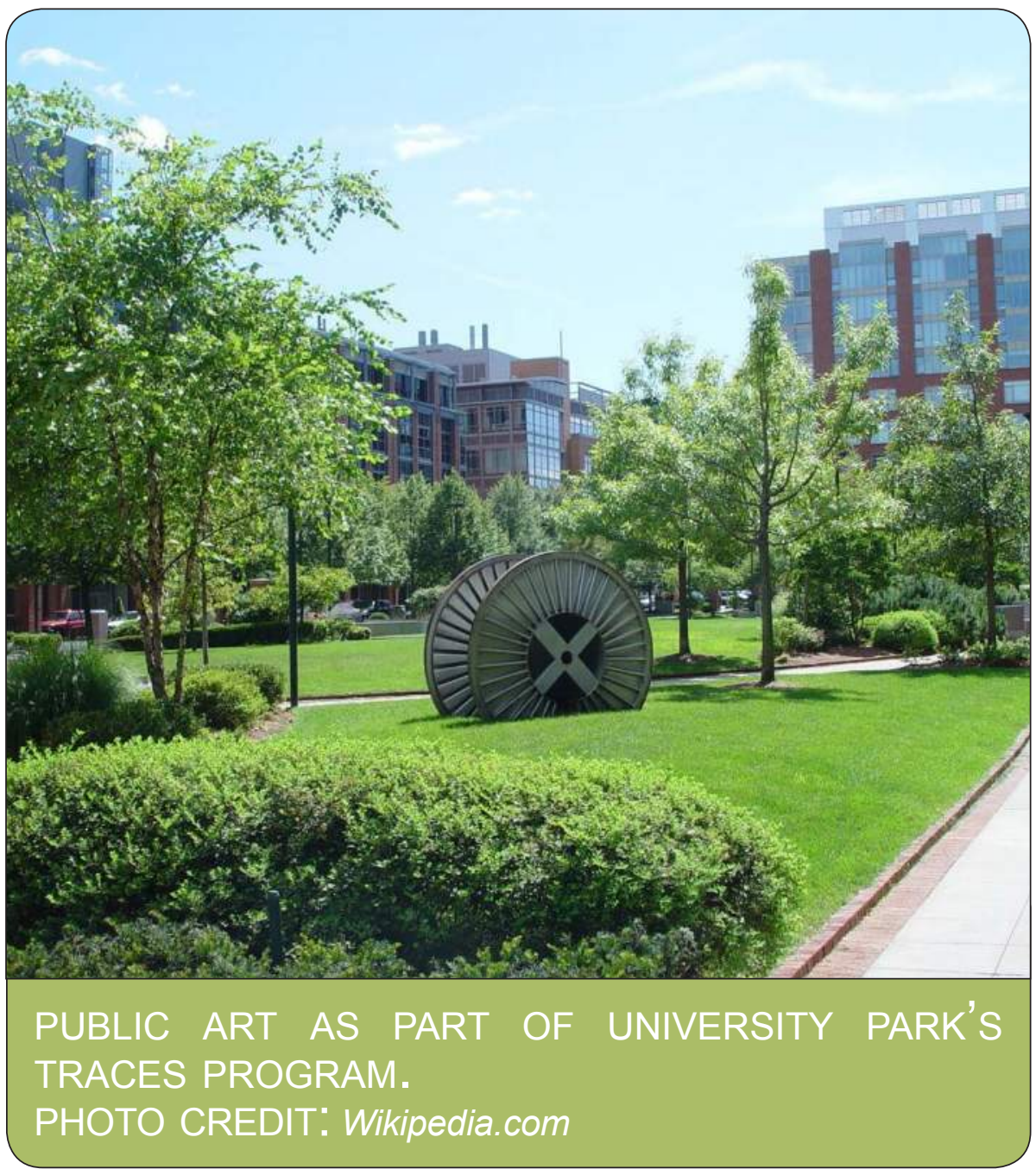


